\title{
A PRÁTICA DO FONOAUDIÓLOGO EM SERVIÇOS DE ATENÇÃO PRIMÁRIA À SAÚDE EM SÃO PAULO: UM ESTUDO DE REPRESENTAÇÕES SOCIAIS
}

\begin{abstract}
Tese apresentada à Faculdade de Saúde Pública, como parte dos requisitos para a obtenção do Título de Doutora. Departamento de Saúde Materno-Infantil.
\end{abstract}

Orientador: Profo. Dr. Arnaldo Augusto Franco de Siqueira

UNIVERSIDADE DE SÃO PAULO

SÃO PAULO

1996

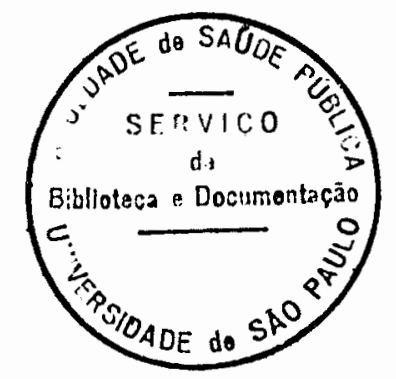


BANCA EXAMINADORA 
"A cada hora se muda não só a hora

Mas o que se crê nela, e a vida passa

Entre viver e ser"

Fernando Pessoa 
À minha mãe

Xenia

pelo exemplo de coragem e determinação

A meu pai

David

Saudades... 


\section{AGRADECIMENTOS}

Ao Prof. Dr. Arnaldo Augusto Franco de Siqueira pela recepção, confiança e preciosa orientação deste trabalho.

À Profa. Dra. Mary Jane Paris Spink por sua sempre pronta colaboração e disponibilidade em todos os momentos deste trabalho.

À Profa. Dra. Silvia Friedman pelo apoio recebido em vários momentos do meu percurso acadêmico e pelas idéias e sugestões recebidas.

À Profa. Dra. Keiko Ogura Buralli pelo carinho e atenção sempre presentes.

À Profa. Dra. Lilia Blima Schraiber pelas sugestões bibliográficas e leitura cuidadosa deste trabalho.

À Profa. Dra. Fumika Peres pela paciência em responder minhas dúvidas.

Às Profs. Dras. Augusta Thereza de Alvarenga e Suzana Magalhães Maia pelas sugestões durante o exame de qualificação.

Ao Prof. Dr. Cornélio Pedroso Rosenburg pelas reflexões e ensinamentos.

Ao Prof. Dr. Orozimbo Alves Costa Filho por tudo que me ensinou até hoje.

À Profa. Dra. Maria Cecilia Bevilacqua por estar presente em todos os momentos importantes.

À Profa. e amiga Maria Cláudia Cunha pelas brincadeiras e também pela ajuda no decorrer deste trabalho.

À Profa. Maria Lúcia Vaz Masson pela bibliografia fornecida e pela amizade.

Aos funcionários de Recursos Humanos das Secretaria de Estado da Saúde e Secretaria Municipal da Saúde pelo fornecimento de dados necessários à pesquisa. 
Às Fgas. Marina, Nelma e Lídia pelos valiosas informações prestadas.

Ao Adolfo pela confecção do mapa.

À Profa. Maria Paula pelo auxílio na revisão gramatical deste trabalho.

À todos os colegas e alunos da Pontificia Universidade Católica de São Paulo pelo incentivo e amizade.

À direção da DERDIC pela compreensão nos momentos finais deste trabalho.

Às amigas Ana Claudia Fiorini, Maria Esperanza Parrado e Maria Paula Roberto pela amizade e incentivo.

Ao Tuto e Vera pela amizade e gostosas discussões.

À Sérgio Amaral pelo apoio e carinho durante vários anos.

$\grave{A}$ aluna e amiga Elaine, sempre disposta a ajudar.

Aos funcionários e conselheiros do Conselho Regional de Fonoaudiologia $2^{a}$ Região pela amizade e compreensão durante a minha ausência.

Ao CEPE-PUC-SP, CNPq e CAPES pelo auxilio concedido.

A todos os Fonoaudiólogos que muito carinhosamente se dispuseram a colaborar com este trabalho.

Um agradecimento muito especial à minha querida irmã Silvia por toda a sua colaboração e principalmente pelo seu carinho e amor. 
O objetivo desse estudo é analisar as representações sociais que norteiam a prática fonoaudiológica nos serviços públicos de saúde no Município de São Paulo, buscando entender como o sentido da prática fonoaudiológica na Atenção Primária à Saúde emerge na interface entre as representações sociais da saúde, mediado pelas experiências concretas da prática cotidiana.

Foram entrevistados 20 Fonoaudiólogos que atuam em Unidades Básicas de Saúde no Municipio de São Paulo, da esfera estadual e municipal, utilizandose a técnica de associação de idéias.

Após a análise dos dados concluímos que:

Os Fonoaudiólogos estão satisfeitos com a escolha profissional, apesar de se sentirem desvalorizados por outros profissionais da saúde.

No que se refere ao seu campo específico de trabalho, os Fonoaudiólogos fundem os conceitos de comunicação, linguagem e fala, provavelmente decorrente de uma formação fragmentada no que se refere à fundamentação teórica.

No que se refere à Saúde e à prática profissional no nível de Atenção Primária à Saúde, pudemos observar que o Fonoaudiólogo fundamenta suas ações em um modelo preventivista.

Finalmente, podemos concluir que o Fonoaudiólogo começa a se reconhecer como profissional da saúde, necessitando refletir sobre sua prática profissional a partir de 2 aspectos: a integralidade da assistência à saúde e a necessidade de se pautar em concepções de saúde mais abrangentes, que fundamentem suas ações. O Fonoaudiólogo deve ainda repensar sua prática na perspectiva da Atenção Primária à Saúde, com caracteristicas únicas e específicas. 
The goal of this research was to analyse the social representations which guide the speech therapișt\&audiologist practice in the Primary Health Care Services in São paulo.

Twenty speech therapists\&audiologists who work in Health Centers were interviewed and the free association technique was used.

After the data analyses we can conclude that:

The speech therapist\&audiologist are satisfied with their professional choice, although they feel that little value is given to their work by other health professional workers.

The speech therapist\&audiologist is gathering the definitions of communication, language and speech, and for this reason misunderstanding their concepts. This may be due to fragmented formation.

In what concerns Health and Primary Health Care, it was observed that the speech therapist\&audiologist uses a preventive model in order to develop his practice.

At last, we can conclude that the the speech therapist\&audiologist recognizes himself as a health worker, but there is the need to reflect about his practice in two aspects: the integrality of the health actions and also the need to use wider health concepts in order to develop his actions. Al of this must be viewed from the Primary Health Care context. 


\section{Página}

\section{RESUMO}

1. INTRODUÇÃO

$\begin{array}{ll}\text { 1.1. Objetivo } & 03\end{array}$

1.2. A Pesquisa Qualitativa em Saúde $\quad 04$

1.3. A Teoria das Representações Sociais 09

2. A FONOAUDIOLOGIA NOS SERVIÇOS PÚBLICOS DE SAÚDE. 21

2.1. A Construção do Perfil Profissional do Fonoaudiólogo 21

2.2. O Nivel de Atenção Primária à Saúde 24

2.3. A Inserção da Fonoaudiologia na esfera municipal de São 31 Paulo Paulo

2.5. A literatura em Fonoaudiologia e Saúde

3. PROCEDIMENTOS PARA COLETA E ANÁLISE DOS DADOS

3.1. Procedimentos para Estudo da Consciência Compartilhada $\quad \mathbf{7 6}$

3.2. Procedimentos para Estudo da Prática no Cotidiano 78

$\begin{array}{ll}\text { 3.3. A escolha dos Sujeitos } & 79\end{array}$

3.3.1. O Universo dos Fonoaudiólogos no Município de São Paulo

3.3.2. Escolha e Caracterização dos Sujeitos $\quad \mathbf{8 2}$

3.4. O Contexto das Entrevistas $\quad 87$

3.5. A Análise dos Dados $\quad 89$

3.5.1. Transcrição de Fitas $\quad 89$

$\begin{array}{lr}\text { 3.5.2. Leitura Flutuante } & 89\end{array}$ 
3.5.3. Mapeamento das Entrevistas

3.5.4. Análise das Representações Sociais na Prática do Cotidiano

4. APRESENTAÇÃO E ANÁLISE DOS DADOS

4.1. Consciência Compartilhada da prática fonoaudiológica em Atenção Primária à Saúde

4.2. Palavra Eliciadora Fonoaudiologia

4.2.1. A Essência da Fonoaudiologia

4.2.2. O Objeto da Fonoaudiologia

4.2.3. Os Mediadores da Prática Fonoaudiológica

4.2.4. Os Qualificadores da Prática Fonoaudiológica

105

4.3. Palavra Eliciadora Saúde

108

4.3.1. A Essência da Saúde

110

4.3.2. O Objeto da Saúde

4.3.3. Os Mediadores da Saúde

4.3.4. Os Qualificadores da Saúde

4.4. Palavra Eliciadora Fonoaudiologia em Atenção Primária à Saúde

4.4.1. A Essência da Fonoaudiologia em Atenção Primária à Saúde

4.4.2. O Objeto da Fonoaudiologia em Atenção Primária à Saúde

4.4.3. Os Mediadores da Fonoaudiologia em Atenção Primária à Saúde

4.4.4. Os Qualificadores da Fonoaudiologia em Atenção Primária à Saúde 
CONCLUSÕES

REFERÊNCIAS BIBLIOGRÁFICAS

ANEXOS 
Meu interesse pelos serviços públicos de saúde teve início durante o desenvolvimento de pesquiša para dissertação de mestrado, em 1983. Pela primeira vez tive a oportunidade de conhecer Unidades Básicas de Saúde (UBSs) que prestavam atendimento de pediatria, ginecologia e odontologia à população de um municipio da Grande São Paulo. Por alguns meses permaneci em duas UBSs avaliando a audição de bebês usuários dessas unidades. Essa experiência, apesar de ter como objetivo o desenvolvimento de um procedimento de avaliação da audição em crianças, aguçou minha curiosidade a respeito do trabalho que poderia ser desenvolvido por Fonoaudiólogos nesses locais.

Em 1986, o Curso de Fonoaudiologia da Pontifícia Universidade Católica de São Paulo (PUC-SP) iniciou a implantação de uma nova grade curricular para seus alunos, com estágios práticos em Unidades Básicas de Saúde e disciplinas eletivas. Foi por meio de uma disciplina eletiva proposta nessa época que iniciei minha carreira docente nessa Universidade. Desde então, passei a desenvolver, junto com alunos do $4^{\circ}$ ano do Curso de Fonoaudiologia da PUC-SP, programas de identificação de perdas auditivas em crianças em unidades de saúde, escolas e creches. Iniciou-se ai um processo de construção, em que a reflexão sobre a prática nas UBSs nunca era esquecida.

Nessa mesma época, alguns professores da PUC-SP começaram a questionar como deveriam ser desenvolvidas as atividades nas UBSs. Um grupo de estudos e pesquisas em Saúde Pública do Programa de Estudos PósGraduados em Distúrbios da Comunicação da PUC-SP teve início com o objetivo de investigar e analisar a prática fonoaudiológica nos serviços públicos de saúde. O Nivel de Atenção Primária sempre foi o mais discutido e pesquisado. 
Sanitária? O que era Epidemiologia? E Epidemiologia Social? O SUS? O que significava ser um profissional da saúde? Como desenvolver um trabalho institucional e interdisciplinarmente? Novas dúvidas, novas procuras, novas discussões. Alguns poucos parceiros participaram desse percurso. Alguns colegas da PUC-SP e também de outras Universidades foram fundamentais para que a curiosidade aumentasse. Os parceiros mais constantes, no entanto, foram alunos de $4^{\circ}$ ano do Curso de Fonoaudiologia da PUC-SP. Enquanto docente, aparecia minha preocupação quanto a formação que esses alunos recebiam.

Os aspectos fonoaudiológicos, principalmente aqueles voltados à área da Audiologia, nunca deixaram de ser meu enfoque. A identificação, diagnóstico e reabilitação de crianças portadoras de deficiência auditiva sempre será motivo de investimento acadêmico, científico e profissional de minha parte. No entanto, a prática fonoaudiológica nos serviços públicos de saúde passou a ser mais um de meus interesses. Esse interesse também se deve à própria dificuldade vivenciada no desenvolvimento de programas de saúde auditiva em crianças.

A decisão pelo ingresso na Faculdade de Saúde Pública foi apenas uma consequência desse processo. Minha prática clínica e também nos serviços públicos de saúde por meio da Universidade me fizeram optar pelo Departamento de Saúde Materno Infantil.

Vários temas de pesquisa surgiram durante os dois primeiros anos de minha formação na Faculdade de Saúde Pública. Posso citar especificamente aqueles voltados à identificação de perdas auditivas em crianças, à rubéola congênita e ao desenvolvimento infantil. Finalmente, optei pelo estudo da prática fonoaudiológica nos serviços públicos de saúde, mais especificamente no nivel de Atenção Primária, por meio do discurso de Fonoaudiólogos que atuam em UBSs no Municipio de São Paulo. Diversas razões nortearam essa escolha, mas a principal delas foi o fato dessa prática ser recente. Recente, mas com um tempo suficiente para que possa ser pesquisada, refletida e repensada. 
A inserção do Fonoaudiólogo no nível de Atenção Primária em Saúde intensificou-se a partir de 1989, principalmente no Município de São Paulo, após dois fatos inéditos: a transferência do Departamento de Saúde Escolar, com seus profissionais, da Secretaria Municipal de Educação para a Secretaria Municipal de Saúde e o concurso realizado por essa Secretaria para inclusão de quase duas centenas de Fonoaudiólogos nos seus quadros. Essa crescente inserção e as necessidades diferenciadas da prática dos profissionais de saúde para atuação na Atenção Primária à Saúde aumentaram minhas inquietaçōes, aguçando meu interesse quanto à prática e transformações necessárias no saber e no fazer do Fonoaudiólogo nesse contexto especificamente.

\subsection{Objetivo}

O objetivo desse estudo foi, assim, analisar as representações sociais que norteiam a prática fonoaudiológica nos serviços públicos de saúde no Município de São Paulo, buscando entender como o sentido da prática fonoaudiológica na Atenção Primária à Saúde emerge na interface entre as representações sociais do fazer fonoaudiológico e as representações sociais da saúde, mediado pelas experiências concretas da prática cotidiana.

Essa análise, realizada a partir do discurso do Fonoaudiólogo, permite que se discuta a prática desse profissional, levando-se em consideração as premissas que embasam a organização do Sistema Único de Saúde, principalmente no que se refere ao sistema hierarquizado de atençăo à saúde.

O contexto escolhido para análise foi o nivel de Atençāo Primária à Saúde por duas razões fundamentais: 
1. Em primeiro lugar, a atuação no nivel de Atenção Primária à Saúde foi considerada como uma estratégia para que se pudesse alcançar, individual e coletivamente, niveis aceitáveis de saúde - "Saúde Para Todos no Ano 2000" conforme a Conferência Internacional sobre Cuidados Primários de Saúde na cidade de Alma-Ata (URSS) em 1978.

A Atenção Primária à Saúde é o primeiro nivel de contato da comunidade com o Sistema Nacional de Saúde, constituindo o primeiro elemento de um processo permanente de assistência à saúde. Além disso, os equipamentos de Atenção Primária à Saúde representam a maioria dos serviços de saúde; são descentralizados e têm como pressuposto atender a grande parte das necessidades de saúde das comunidades, por meio da atenção integral à saúde dos indivíduos.

2. Em segundo lugar, os Fonoaudiólogos concursados e atuando no Municipio de São Paulo, seja no âmbito Municipal ou Estadual, estão lotados na sua maioria em Unidades Básicas de Saúde ou Centros de Saúde, ou seja, em unidades responsáveis pelo nivel de Atenção Primária à Saúde.

Pretende-se que este estudo possa colaborar para a reflexão, no sentido de se repensar a prática fonoaudiológica em Unidades Básicas de Saúde, contribuindo assim, tanto para o campo de estudos da Saúde Pública como para a própria Fonoaudiologia.

\subsection{A Pesquisa Qualitativa em Saúde}

Segundo Minayo (1994) a metodologia é "o caminho do pensamento e a prática exercida na abordagem da realidade." A metodologia inclui tanto as concepções teóricas de abordagem, como o conjunto de técnicas que possibilitam a construção da realidade e a criatividade do pesquisador. Colocou ainda a autora, que no que se refere às concepções teóricas de abordagem, teoria e metodologia caminham juntas. Enquanto conjunto de técnicas, a 
metodologia "deve disporde um instrumental claro, coerente, elaborado, capaz de encaminhar os impasses teóricos para o desafio da prática."

A autora colocou ainda a pesquisa como uma atividade básica da ciência, indagando e construindo a realidade. A pesquisa fornece subsidios para o ensino, alimentando-o e atualizando-o frente à realidade do mundo. Apesar de prática teórica, a pesquisa vincula o pensamento e a ação, já que não existem problemas que não tenham sido problemas na vida prática.

Minayo (1994) argumentou que o conhecimento anterior construído por outros pesquisadores apontam caminhos para a questão de nossa pesquisa. É o que se chama de teoria, que "é construida para explicar ou compreender um fenômeno, um processo ou um conjunto de fenómenos e processos." As teorias não conseguem explicar todos fenômenos e processos, e são portanto, explicações parciais da realidade, que podem colaborar para esclarecer o objeto de estudo; que ajudam a propor questōes e hipóteses com maior propriedade; que permitem maior clareza na organização dos dados; e que podem apontar caminhos para a análise dos dados.

Ainda segundo Minayo (1994), a pesquisa qualitativa responde a questōes específicas. Colocou a autora que a pesquisa qualitativa se preocupa nas ciências sociais "com um nivel de realidade que não pode ser quantificado", operando com um universo de significados, motivos, aspiraçōes, crenças, valores $e$ atitudes que se referem ao espaço das relações que não podem ser reduzidos à operacionalização de variáveis.

Para Minayo (1994) a diferença entre a pesquisa qualitativa e quantitativa está na sua natureza. Os dados obtidos pela estatística podem apreender os fenômenos visíveis, ecológicos, morfológicos e concretos. $\mathrm{Na}$ abordagem qualitativa é possivel se aprofundar nos significados das ações e das relações humanas. Para a autora, os dados quantitativos e qualitativos não se opõem; se complementam pois, as diferentes realidades abrangidas podem interagir 
dinamicamente. No entanto, a autora colocou que outras correntes de pensamento, como o Positivismo, não estão de acordo com estas questões. Explicou então, que o Positivismo utiliza-se de um modelo matemático para a compreensão da realidade, ątravés dos princípios das ciências da natureza onde: "o mundo social opera de acordo com leis causais; o alicerce da ciência é a observação sensorial; a realidade consiste em estruturas e instituições identificáveis enquanto dados brutos de um lado e crenças e valores por outro; o que é real são os dados brutos; valores e crenças são dados subjetivos que só podem ser compreendidos através dos primeiros."

A autora contrapôs o Positivismo mostrando que a Sociologia Compreensiva aborda diferentemente a questão da pesquisa qualitativa, apontando que essa corrente teórica "coloca como tarefa central das ciências sociais a compreensão da realidade humana vivida socialmente." $\mathrm{Na}$ Fenomenologia, na Etnometodologia, no Interacionismo Simbólico o conceito central da investigação está voltado para o significado. A Sociologia Compreensiva propõe a subjetividade como o fundamento do sentido da vida social e coloca-a como constitutiva do social e inerente à construção da objetividade nas ciências sociais. Os seguidores dessa corrente não se preocupam em quantificar, mas sim em " compreender e explicar a dinâmica das relações sociais, que são por sua vez depositárias de crenças, valores atitudes e hábitos. Trabalham com a vivência, com a experiência, com a cotidianeidade $e$ também com a compreensão das estruturas e instituições como resultados da ação humana objetivada. Ou seja, desse ponto de vista, a linguagem, as práticas e as coisas são inseparáveis."

Marsiglia (1992) apresentou os resultados parciais de uma pesquisa, envolvendo diversas instituições, que tinha como objetivo investigar a questão do processo de trabalho dos serviços de saúde em nivel de atenção primária. 0 foco de atenção da pesquisa dirigiu-se a centros de saúde da rede estadual, e também investigou as representações dos funcionários a respeito de seu trabalho, da clientela, do processo saúde/doença e da finalidade do centro de 
saúde. A opção pela pesquisa qualitativa, predominantemente, fez com que fossem utilizados métodos antropológicos e sociológicos, sem descartar a quantificação. Foi utilizado um roteiro com 17 perguntas para a caracterização do perfil dos funcionários entrevistados. Um segundo roteiro foi utilizado para que se pudesse realizar entrevistas em profundidade. Esse último tinha como meta obter dados no que se refere à inserção do profissional no seu trabalho, a compreensão que tinha do centro de saúde, de sua clientela, aspirações voltadas a ascensão profissional e o processo saúde/doença, entre outras questões. Além das entrevistas, foi realizada uma observação sobre o processo de trabalho.

Schraiber (1995) em artigo que discute a pesquisa qualitativa, apresentou detalhadamente algumas reflexões metodológicas do relato oral e da produção de narrativas. Tais reflexōes surgiram a partir de uma investigação realizada com o objetivo de obter informações sobre o trabalho médico no Brasil, estudando-se a história da passagem da medicina liberal para a medicina especializada, e também as representações dos médicos acerca desse processo e de si mesmos enquanto agentes técnicos e sujeitos históricos. Os dados foram obtidos a partir de textos da história da medicina no Brasil, textos que debatiam o exercício profissional na época em discussão e textos biográficos. Houve ainda a contribuição de personagens que participaram do processo histórico através de entrevistas denominadas de testemunhos pessoais.

A autora descreveu que dentre as possibilidades da pesquisa qualitativa, optou-se por realizar "uma modalidade orientada para produzir relatos com um misto de lembranças das histórias pessoais da vida de trabalho com reflexões mais gerais sobre o trabalho médico e sobre o movimento de suas transformações." Foi estimulada a produção de narrativas mais livres, impondose limites à temática para que todas as questōes levantadas pudessem ser abordadas. Dessa forma, a autora colocou que mesmo nas entrevistas abertas há situações onde o pesquisador limita e controla o entrevistado, definindo temas, cortes e até o final da entrevista. São os depoimentos pessoais. Para o entrevistado que teve uma narrativa livre, conduzindo seu próprio ritmo, 
denominou-se a história de vida. Também foram utilizadas as observações dos cotidianos, ou mais precisamente, a prática profissional de médicos-comuns. Segundo Schraiber (1995) "esta prática expressa o modo de produzir os serviços médicos nas condições do: dia-a-dia, em que o ato médico uniforme e único enquanto modo genérico de medicina, é re-produzido nas desiguais situações de trabalho concretamente existentes na sociedade; reprodução que, na particular situação de trabalho experimentada individualmente pelo médico, significa reelaboração dos pressupostos e expectativas homogêneas dos médicos, enquanto pensamento coletivo acerca do trabalho médico ideal."

No que se refere aos aspectos técnicos e ao cotidiano da pesquisa, Schraiber (1995) argumentou que deve-se definir quem e quantos serão os entrevistados, que produzem narrativas com um volume grande de material coletado. No que se refere à intervenção do pesquisador durante a entrevista, não existem normas que podem ser reproduzidas em todas as entrevistas. É por esse motivo que sugeriu que a entrevista seja conduzida com uma atualização do roteiro. O roteiro tem o papel de guia da narrativa, e é utilizado para que se coloque temas estimulantes que se constituem como um apoio ao trabalho de reflexão. Nas suas considerações finais, a autora creditou à pesquisa qualitativa, e particularmente à produção de narrativas, "a característica de ferramenta extremamente apropriada para o estudo das representações."

Spink (1993) argumentou que para a análise das representaçōes sociais, o pesquisador deve acessar o diálogo interno e externo existente entre os individuos. Dessa forma, o uso de material espontâneo, induzido por questōes, expresso livremente em entrevistas ou cristalizado em produções sociais tais como livros, documentos, memórias, matérias de jornal e revistas, deve ser utilizado. A autora colocou três formas mais comumente utilizadas para a obtenção de tais dados:

1. Técnicas Verbais: as mais utilizadas e a forma mais comum de se acessar as representações. Há uma preferência por entrevistas abertas, obtidas 
a partir de um roteiro mínimo elaborado. É possivel assim que se evite que categorias pré-concebidas pelo pesquisador possam interferir nos dados obtidos.

2. Associações-Livres: Vem assumindo maior importância na pesquisa com Representações Sociais. Através do uso de pequeno número de palavrasestimulo. Segundo Spink (1993) "esta técnica tem sido favorecida especialmente por se prestar à análise multivariável que permite superar um dos problemas mais sérios das análises de conteúdo, ou seja, o caráter hermenêutico das interpretações."

3. Técnicas Não-Verbais: Vêm sendo mais utilizadas por alguns autores como De Rosa por exemplo, que usou o desenho para sua pesquisa com crianças e adultos sobre a doença mental.

Spink (1989) colocou que o processo saúde/doença constitui um campo fértil para o estudo sobre as representações sociais. Isto se dá pois em primeiro lugar, o modelo médico reduz a saúde/doença ao estado orgânico do corpo individual ou coletivo, que é cuidado pelas diferentes instituições de saúde. A autora argumentou que entretanto, "a doença remete a uma interrogação que extrapola o corpo individual e o diagnóstico médico. A busca de seu significado remete necessariamente a uma interpretação coletiva complexa e em constante movimento. Remete, em suma, ao discurso da sociedade sobre as enfermidades e os enfermos."

Por termos optado nesta investigação pela Teoria das Representações Sociais, é que apresentaremos uma revisão apontando seu estado atual e alguns debates surgidos a partir de diferentes reflexões.

\subsection{A Teoria das Representações Sociais}

Várias discussões têm gerado debates no que se refere à Teoria das Representações Sociais. Algumas colocações de diferentes autores podem 
apontar caminhos diversos e que nos levaram por fim à essa escolha teórica especificamente.

Segundo Moscovici (1978) uma representação social. "é uma modalidade de conhecimento particular que tem por função a elaboração de comportamentos e a comunicação entre indivíduos." O autor comentou que "a representação social é um corpus organizado de conhecimentos e uma das atividades psíquicas graças às quais os homens tornam inteligivel a realidade física e social, inserindose num grupo ou numa ligação cotidiana de trocas, liberando os poderes da imaginação."

Moscovici (1978) comentou ainda, que a representação social é a organização de imagens e conceitos, que possibilitam que situações estranhas se tornem comuns.

Segundo Spink (1989), para que se lide com a percepção estranha recorre-se a dois processos enunciados por Moscovici: o de ancoragem e o de objetivação. A ancoragem, refere-se a inserção orgânica do que é estranho no pensamento constituído. É desta forma que ancoramos o desconhecido em representações já existentes. A objetivação, refere-se a constituição formal do conhecimento. É o processo através do qual as noções abstratas são transformadas em imagens e organizadas ao redor de núcleos figurativos estruturantes da representação.

Moscovici (1978) colocou ainda que, as representações sociais têm uma função constitutiva da realidade. A representação social é formada vinculando-se conhecimentos ou experiências a um sistema de valores, de noções e práticas, possibilitando que os indivíduos se orientem no seu meio social e material, tornando possivel para estes dominá-lo.

Para Moscovici (1988) as representações sociais se referem ao pensamento cotidiano, e ao conjunto de idéias que dão coerência às nossas crenças religiosas, às idéias políticas e às conexões que criamos tão 
espontaneamente quanto respiramos. As representações fazem com que seja possivel que se classifique as pessoas e os objetos, explicando e comparando seus comportamentos e finalmente objetivando-os como parte de nosso cenário social.

Jodelet (1986) argumentou que as representações sociais são uma maneira de interpretar e de pensar nossa realidade cotidiana; uma forma de conhecimento social. É uma atividade realizada pelos individuos, com o objetivo de colocar suas posições em relação a determinadas situações, acontecimentos, objetos e comunicações. O social pode intervir de diferentes maneiras: através da comunicação que se estabelece entre os indivíduos, através dos marcos de apreensão de suas bagagens culturais, através dos códigos, valores e ideologias relacionados com as posições sociais específicas. A representação se refere à maneira como nós, sujeitos sociais, interpretamos os acontecimentos da vida diária, as características do nosso meio-ambiente, as informações que circulam, e as pessoas próximas a nós. É um conhecimento denominado de senso comum. Ele se constitui a partir de nossas experiências, através das informações, conhecimentos e modelos de pensamento que recebemos por meio da tradição, da educação e da comunicação social. Assim, pode-se dizer que é um conhecimento socialmente elaborado e compartilhado.

Uma das questões que se levanta sobre as Representações Sociais é quanto ao seu status. De Rosa (1992) questionou o status das representações sociais indagando se estas são um conceito heurístico, um paradigma, uma teoria ou simplesmente um fenômeno.

Potter \& Litton (1985) criaram uma polêmica ao definirem as Representações Sociais como "um conceito em busca de uma teoria". Os autores definiram a teoria proposta como vaga, pouco clara e muito ampla. Apontaram quatro problemas relacionados entre si, a partir da teoria formulada por Moscovici: 
1. Relação entre grupos e as representações sociais: diferenças que podem ser encontradas dentro de um mesmo grupo social, que resultam na formação de intragrupos dentro de cada grupo;

2. Problemas de conseņso e o nível no qual as representações sociais são compartilhadas: a similaridade pode obscurecer a aparição de diferenças nas representações intragrupo, dependendo da forma como a análise for realizada;

3. Representações sociais em contextos particulares: podem haver dificuldades na análise das representações a partir de variações no contexto;

4. Papel da linguagem nas representações sociais: a importância da linguagem e a interpretação do pesquisador podendo levar a uma transformação da representação social.

Respondendo ao comentário de Potter \& Litton, Moscovici (1985) reafirmou a existência de uma teoria das Representações Sociais, colocando-as como um fenômeno de nossa realidade social e com influência do cotidiano na nossa maneira de pensar e em nossas relações sociais. Argumentou ainda que aqueles que optam pelas Representações Sociais estão interessados na compreensão de por quê as representações são produzidas pelo homem e como elas intervêm na vida social. Quanto ao fato de estar pautada em uma teoria vaga, o autor colocou que esse fato não implica em risco, tendo inclusive um papel positivo na Psicologia Social. Afirmou ainda, que as Representações Sociais necessitam da construção de teorias descritivas e explicativas que fundamentem amplamente $o$ fenômeno. A clareza e as definições serão o resultado da pesquisa, antes de ser um pré-requisito da mesma.

Outro autor que apontou dificuldades na teoria proposta por Moscovici foi Jahoda (1988). Apesar de ter considerado as idéias teóricas como uma forma de se transformar radicalmente a Psicologia Social, apontou contradições, inconsistências e dúvidas no que se refere à lógica das Representações Sociais. O autor referiu-se às colocações de Moscovici quanto à representação coletiva em contrapartida à representação social, à retomada do pensamento coletivo, à relação entre representações sociais e ideologia, à relação entre representações 
sociais e cultura, às representações sociais e processos psicológicos individuais, ao teste da teoria como fator que remetesse à qualidade da evidência empirica e à aplicação ilimitada do conceito de representação social. O autor apontou que se os pontos acima forem remediados e novos conceitos incorporados, pode-se alcançar o desafio pioneiro de transformação da Psicologia Social proposto por Moscovici.

Ibáñez (1994) colocou que as pesquisas constituídas a partir da teoria das Representações Sociais de Moscovici continuarão progredindo ainda nos próximos anos. Apontou também, algumas críticas que devem ser feitas com relação à essa teoria. O autor colocou que a maioria das críticas tem sido apontadas por autores que se fundamentaram na análise do discurso e na retórica, argumentando que a teoria das Representações Sociais não se encontra tão em oposição às vertentes cognitivistas como se pretendia. Ibáñez colocou que a teoria das Representações Sociais lida especificamente com o pensamento social, e que este é constituído contemporaneamente por algum tipo de material representacional. $\mathrm{O}$ autor colocou ainda que o homem não vive em um mundo de representações, mas em um mundo de produções discursivas, pois é um ser falante que comunica "alguma coisa" que construiu através de categorias de nossa linguagem. As pessoas constróem a realidade através de seu discurso, ou seja, é a prática de se construir sistematicamente sobre o objeto do qual se fala.

Ibáñez(1994) colocou ainda que a teoria das Representações Sociais se refere mais diretamente a um processo de transformação ou de re-construção, mais do que a um processo de construção, pois se originou em objetos prédados, já elaborados em outros discursos e que precisam ser re-construidos para serem assimilados. A conclusão de seu artigo "Construindo uma Representação ou Representando um Construção?" apontou para não como representamos a realidade, mas sim para como construímos a realidade, saindo do nivel fenomenológico das representações para o nivel ontológico das mesmas. 
Segundo Spink (1993) as representações sociais, enquanto campo de conhecimento, podem ser abordadas de duas maneiras distintas. Na primeira, é o estatuto do conhecimento que está em pauta, ou seja, sua natureza e seus pressupostos epistemológicos. Na segunda, é a sua funcionalidade. Colocou a autora que: "o conhecimento estudado via representações sociais é sempre um 'conhecimento prático'; além de ser sempre uma forma comprometida e/ou negociada de interpretar a realidade. Nesta vertente, a tendência tem sido eliminar a expressão 'representação social', adotando em seu lugar a expressão 'práticas discursivas', numa tentativa de eliminar a confusão seminal do conceito de representação social, que, inevitavelmente, situa-se entre dois paradigmas: o da modernidade e o da pós-modernidade."

Segundo De Rosa (1992), existem diferentes niveis pelos quais as Representações Sociais podem existir. Enquanto fenômeno, as Representações Sociais são uma forma de conhecimento da realidade social, que emergem no cotidiano durante as comunicações interpessoais. Enquanto teoria as Representações Sociais são um conjunto de definições conceituais, de operações metodológicas e formulação de constructos que tem as representações como seu objeto. Como meta-teoria as representações são a soma de proposições críticas, respostas e comparações com outros modelos teóricos que surgiram a partir do debate que se criou sobre a teoria das representaçōes.

De Rosa (1992) afirmou: "...acredito que o debate metateórico sobre as Representações Sociais representa o local ideal para o confronto entre as visões críticas para uma melhor definição da teoria. Além disso, esse confronto evitará que as Representações Sociais se tornem mais um dos "paradigmas solitários", fato esse que o próprio Moscovici (1984) reconhece como comum à vários modelos teóricos que aparecem e desaparecem a cada 10 anos na Psicologia Social." 
Harré (1984) questionou a natureza do social nas Representações Sociais, afirmando que mesmo Moscovici não explorou o que poderia do conceito de "social" para sua teoria. As críticas de Harré se basearam nos conceitos de social que se referem a: pluralidade distributiva, ou seja, quando um grupo se constitui pois, cada membro tem alguns atributos similares aos outros membros; e pluralidade coletiva, ou seja, o grupo tem um atributo que não é o atributo de nenhum dos membros. Harré afirmou: "As Representações Sociais não são sociais no sentido de se pertencer a um grupo; elas são representações individuais, cada uma das quais é similar a cada uma das outras. Claro, logo se aprende a ler a expressão 'representação social' com o significado de representação individual distribuída; mas isto não resolve a dificuldade que a terminologia mostra. Ela obscurece a distinção entre 'social = conjunto similar de representações individuais' e social = representação social (que é coletiva). 0 uso do "social" é ainda em última análise, uma versão do individualismo."

De Rosa (1992) realimentou o debate colocando que mesmo ao se entender as representações coletivas como entidades meta-históricas, estáticas e imutáveis no tempo e no espaço, "não fica claro como elas podem ser conhecidas, reproduzidas e reinventadas se não através de indivíduos e grupos que usufruem da herança cultural e reativam-as no seu contexto social através de várias mediações simbólicas."

Dentre os defensores da subjetividade aparece De Rosa (1992) que apesar de ressaltar o caráter social das representações coloca: "...é o indivíduo que, a um certo ponto, integra e modifica as formas sociais de culturas e grupos do qual pertence e quem, independentemente das inúmeras mediações oferecidas pelas representações sociais (instituições, poderes, leis, mídia, etc.), no final transmite e expressa as representações sociais."

De Rosa (1992) ao hipotetizar o processo circular de co-evolução entre a Representação Social e a representação individual social argumentou que "em processos de influência social e socialização, o ator adquiriu, adaptou e 
internalizou a Representação Social de seu grupo. Como 'representação individual social' elas são agora parte de seu sistema de conhecimento. A partir da combinação desse conhecimento e de sua percepção do ambiente e de si mesmo, o ator desenvolve àspectos cognitivos relacionados com a ação que a guiam de várias formas...Em seguida, ele realiza a ação. Como ele opera no contexto de seu grupo, sua ação também é parte da ação grupal. Dos vários "feedbacks" que recebe durante a ação e a partir dos resultados obtidos, após muitos desses ciclos, gradualmente ou abruptamente, seu conhecimento e consequentemente sua ação se modificam. Cedo ou tarde seu conhecimento modificado é transferido ao grupo e as Representações Sociais do grupo se modificam."

Segundo De Rosa (1992), Moscovici apontou em vários momentos que o consenso, ou o compartilhar não se refere a uma concepção estática, de frequência, distribuitiva ou estatística, mas sim a uma concepção que pressupõe códigos comunicativos e simbólicos iguais.

Segundo Spink \& Gimenes (1994) conhecer é dar sentido ao mundo e na ótica da produção do sentido "implica, sobretudo, no posicionamento perante os dados, as teorias e os outros - nossos interlocutores diretos ou genéricos." Com relação ao posicionamento, a produção de sentido é colocada pelas autoras como um processo de negociação continuada de identidades sociais. Assim, dar sentido é uma atividade cognitiva, que implica "no uso de conexões neurais habituais desenvolvidas pela experiencia no enquadre das contingências do contexto cultural e social." Há, portanto, a interface entre dois tempos distintos: tempo histórico: em que se inscrevem os conteúdos imaginários derivados das formações discursivas de diferentes épocas; e o tempo vivido: em que se inscrevem os conteúdos derivados dos processos de socialização primária e secundária. As autoras colocaram ainda que dar sentido implica também em posicionar-se em uma rede de relaçōes, voltada à intersubjetividade. É o tempo presente: se refere a microescala da interação social; através da atividade criativa haverá a construção de novos sentidos. Colocaram ainda que, dar 
sentido implica em posicionar-se no fluxo dos acontecimentos, estabelecendo coerência e continuidade para que o indivíduo possa reconhecer-se como sujeito histórico.

Ainda segundo Spink e Gimenes (1994), o dado empírico para a compreensão do conhecimento como produção do sentido são as práticas discursivas, entendidas como "as diferentes maneiras em que as pessoas, através do discurso, ativamente produzem realidades psicológicas e sociais". O discurso é entendido como "o uso institucionalizado da linguagem e de sistemas de sinais de tipo lingüístico". Os discursos podem competir entre si e criar versões da realidade distintas e incompatíveis, trazendo a tona, portanto, a polissemia gerada pelas práticas discursivas.

As autoras afirmaram ainda que, no que se refere à sequencialidade, as práticas discursivas por serem práticas sociais pautadas na intersubjetividade, estão presas a contextos especificos que se marcados por uma assimetria nas relações, podem inibir o aparecimento da polissemia. No entanto, a concomitância de diversas narrativas tende a aparecer.

Spink e Gimenes (1994) retomaram uma noção de escala colocada por Moscovici, que afirmou haver diferenças entre as representações quando trabalhadas no nível pessoa-a-pessoa, no nivel das relaçöes entre indivíduos e 0 grupo, ou no nivel da consciência compartilhada da sociedade. Para cada um desses niveis as representações têm um sentido diferente.

As autoras colocaram que as práticas discursivas que permitem o acesso a produção de sentido estão na escala das relações pessoa-a-pessoa. "Entretanto, a apreensão de diferentes narrativas implica em ter familiaridade com a diversidade própria ao imaginário social sobre os objetos que são foco dos processos de significação. As construções históricas destes objetos...constituem o contexto interpretativo essencial para a aproximação aos modos de produção do sentido." 
Ao se trabalhar na escala da consciência compartilhada entre o indivíduo e o grupo que o individuo tem como referência, o que se tenta apreender é o que há de comum entre as pèssoas que são informantes. Refere-se aqui às representações sociais, nas quais é necessário que se entrevistem muitos para que se chegue a uma distribuição das idéias constitutivas numa determinada população. Spink e Gimenes (1994) denominaram esta etapa metaforicamente de "epidemiologia" das idéias.

Spink e Gimenes (1994) colocaram que ao se trabalhar nas escalas de pessoa-a-pessoa e consciência compartilhada de forma articulada, a análise encontra-se centrada na produção de sentido, o que significa um trabalho voltado à processualidade, "à luz de permanências culturais e sociais e à luz da funcionalidade do discurso frente ao contexto de sua produção."

As autoras apontam ainda para quatro passos para que se possa chegar à compreensão do sentido:

1. Por se tratar de um fenômeno na esfera da intersubjetividade, em primeiro lugar é necessário que se compreenda como o espaço da interlocução foi utilizado. Ou seja, deve-se buscar compreender a interface entre as intenções do entrevistador e as hipóteses sobre a situação de entrevista por parte do entrevistado.

2. O segundo passo refere-se à compreensão de quem são os interlocutores, ou seja, a quem o discurso produzido está sendo remetido. As descontinuidades discursivas podem ser reveladas através de novos interlocutores no discurso.

3. O terceiro passo refere-se aos repertórios lingüísticos, onde a recorrência de termos são utilizados para caracterizar ações ou eventos. Podese assim chegar à variabilidade dos repertórios que nos remetem a indicadores 
tais como a ambigüidade - múltiplos significados, a contradição - sentidos antagônicos, a inconsistência - significados instáveis e a incoerência transgressão de regras que sugere outra narrativa

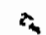

4. O quarto passo, já no campo da retórica, busca a argumentação e a depositação de valores, ou seja, procura-se os qualificadores que revelam o investimento afetivo.

Spink e Gimenez (1994) apontaram para o fato de que ao se trabalhar com a produção de sentido, por ser um processo intersubjetivo, não se abandona a perspectiva social para se privilegiar a intraindividual. Apontam as autoras que se trata de um esforço em 'direção ao posicionamento, voltado à ordem dos movimentos identitários. Argumentaram ainda que "a identidade neste sentido é uma permanente negociação de posições desejadas, assumidas ou instauradas pelo processo interativo." Colocaram ainda, que não se pode compreender os processos de produção do sentido sem voltarmos aos níveis onde as idéias circulam na sociedade. Ou seja, no nivel de consciência social compartilhada, onde as representações sustentam a comunicação e a identidade dos grupos; e no nivel histórico cultural do imaginário, onde há a produção cumulativa de idéias que circulam e que podem ser resignificadas em uma determinada formação social.

Finalizaram ainda as autoras que "desvelar o sentido não é apenas um afã acadêmico. Trata-se também de tarefa permeada de implicações práticas, seja pela possibilidade de construção de novas narrativas que sustentam novas formas de posicionar-se no mundo; seja pelas implicações absolutamente funcionais no campo da saúde."

A partir do interesse deste trabalho em investigar a prática fonoaudiológica, a escolha teórico-metodológica deu-se através do estudo das Representações Sociais de Fonoaudiólogos que atuavam no município de São Paulo, mais especificamente em serviços públicos de saúde no Nível de Atenção 
Primária, buscando entender a produção de sentido na interface entre a consciência compartilhada, ou seja, os conteúdos compartilhados e derivados do saber fonoaudiológico e a prática do cotidiano desse profissional, através da experiência pessoal no nível dạ prática profissional efetiva.

O presente estudo pode apontar reflexōes voltadas à prática profissional do Fonoaudiólogo, ao analisar as articulações possiveis dos aspectos voltados ao seu conteúdo histórico e cultural, à formação profissional e das experiências profissionais que fazem com que ele reinterprete, resignifique e desenvolva ações de saúde pautadas no seu posicionamento frente a esse novo contexto profissional. 


\subsection{A Construção do Perfịl Profissional do Fonoaudiólogo}

Em 9 de dezembro de 1981, a Lei 6.965 regulamentou a profissão de Fonoaudiólogo, reconhecido em todo o território nacional como o profissional com graduação plena em Fonoaudiologia, que atua em pesquisa, prevenção, avaliação e terapia fonoaudiológicas na área de comunicação oral e escrita, voz e audição, bem como em aperfeiçoamento dos padrões da fala e da voz. (Brasil, 1981).

Apesar da regulamentação da profissão ter se dado apenas em 1981, o movimento que delineia a Área de Distúrbios da Comunicação tem seus primórdios marcados no início deste século. Serão ressaltados alguns marcos desse processo de construção, dada a importância desse conhecimento para que se possa analisar a construção desse fazer profissional.

A construção da identidade do Fonoaudiólogo no Brasil está permeada por valores e concepções originados na década de 20 . Berberian (1993), por meio de pesquisa que analisou documentos das décadas de 1920 a 1940, mostrou o surgimento de uma politica de controle da linguagem e a criação de medidas de padronização e normatização da língua nacional, que atingiam aqueles individuos portadores de patologias, e principalmente os indivíduos que apresentavam "diferenças de linguagem em função de variações dialetais que caracterizavam, de forma significativa, a língua falada no país e que vinham contaminando a lingua oficial do Brasil." 
É possivel afirmar que as práticas desenvolvidas pelos antecessores dos Fonoaudiólogos, estavam pautadas na correção das diferenças encontradas na linguagem de indivíduos às vezes portadores de uma patologia da linguagem, e muitas vezes apontados como "diferentes" graças a uma diferença cultural, regional e principalmente pelas diferenças na sua inserção social. Além disso, o profissional que atuava nos distúrbios e desvios da linguagem, sem uma formação especifica, tinha sua prática pautada por pressupostos da Medicina, da Psicologia e também da Educação.

Figueiredo Neto (1988) colocou que um enfoque "médico-social" pode ser constatado no início da prática fonoaudiológica no Brasil, refletindo as idéias higienistas que permeavam a Saúde do Escolar e as idéias escolanovistas da Educação.

Berberian (1993) analisou que a atuação dos profissionais responsáveis pela correção dos distúrbios da fala e audição no início do século propiciou uma fragmentação do sujeito, enquanto emissor/receptor de um sistema previamente estabelecido, pois se fundamentava em uma visão funcionalista e fragmentada da linguagem. Existia o ser "falante" e o ser "ouvinte", partes distintas e independentes do sujeito, assim como a língua era dividida em forma e conteúdo. Nota-se então uma razão histórica para a cisão existente entre as duas sub-áreas da Fonoaudiologia - "Audiologia" e "Linguagem".

Surgiram na década de 60 , os primeiros cursos de Fonoaudiologia, com a necessidade de formar um profissional especializado em patologias de linguagem, uma vez que educadores e recreacionistas vinham desenvolvendo essas funções.

No final da década de 70, foram oficialmente reconhecidos os Cursos de Fonoaudiologia com nivel de tecnólogo. O relatório aprovado em 1974 pelo Conselho Federal de Educação sobre a Formação de Tecnólogos em 
Fonoaudiologia conceituou o Fonoaudiólogo como um técnico que exerce atividades paramédicas. Além disso, coloca a Fonoaudiologia como parte da Foniatria e limitando-a a avaliação e reabilitação técnicas dos sistemas de comunicação, ou seja, a audição, a voz, a fala e a linguagem (Cappeletti, 1985).

Segundo Maia (1987), os Cursos de Fonoaudiologia procuravam formar um profissional para atuar na detecção e terapia de indivíduos portadores de patologias da linguagem e audição. Para tanto era necessário que esses profissionais lidassem com acervos de outras áreas que Ihes subsidiariam no conhecimento dos padrões de normalidade. Tais padrōes poderiam ser aplicados às patologias da comunicação, explicando os desvios e justificando as práticas diagnósticas e terapêuticas. Foi dessa forma que "delineou-se assim 0 perfil de um profissional de natureza clínica, que sem saber exatamente que doença de linguagem era esta, teve como alternativa única a correção dos desvios."

A partir da formação dos primeiros cursos, mas principalmente após a regulamentação da profissão na década de 80 , iniciou-se um movimento de reflexão sobre a identidade do Fonoaudiólogo, buscando superar uma formação tecnicista, com a intenção de constituir uma área de conhecimento própria, a partir de novas e velhas concepções.

A pesquisa de Cunha (1986), que realizou uma reflexão sobre o normal e o patológico em Distúrbios da Comunicação, reivindicou para essa área uma fundamentação filosófica, e uma reflexão sobre "o uso desatinado do empirismo tanto no trabalho clínico, como na formação acadêmica".

Maia (1987) descreveu um movimento interessante e contraditório da Fonoaudiologia, que "parece disposta a mergulhar em si mesma para entender suas origens, seus caminhos e descaminhos, em um momento saudável na busca de sua identidade, rastreando a sua história, identificando as suas marcas." 
Já Cunha (1989) apontou para o fato de haver uma crise de conhecimento na área de Distúrbios da Comunicação, que é histórica e socialmente determinada. Tal afirmação se pautou nas críticas feitas à Fonoaudiologia, apontada por alguns como uma prática tecnicista, ou não científica. A autora colocou ainda, que algumas respostas a essas críticas têm sido respondidas utilizando-se de empréstimos de outras ciências que após serem somadas "resultariam numa clínica fonoaudiológica que daria conta do individual, do social, do histórico, do epistemológico..."

No final dos anos 80 , e em meio a esse período de crise, o Fonoaudiólogo se inseriu com maior ênfase nos serviços públicos de saúde, e mais especificamente na Unidades Básicas de Saúde no nível de Atenção Primária. Ao mesmo tempo que refletia sobre sua prática clínica, se inseria em um novo contexto, que também passava por transformações: a reforma constitucional e a implantação do Sistema Único de Saúde, trazendo novos desafios e questionamentos.

Houve um aumento significativo das produções que se voltavam para esse novo contexto de atuação, buscando novos conhecimentos que pudessem contribuir para uma transformação do fazer profissional do Fonoaudiólogo.

\subsection{O Nivel de Atenção Primária à Saúde}

Para Kroeger e Luna (1987), o marco conceitual da Atenção Primária à Saúde se deu em Alma-Ata (Rússia) em 1978, durante assembléia da Organização Mundial de Saúde. Todos os países concordaram em definir uma politica de saúde que tivesse como objetivo a "Saúde Para Todos No Ano 2000". A estratégia definida para se alcançar tal objetivo foi a Atenção Primária à Saúde. 
Segundo Cyrino (1993) o desenvolvimento de um racionalização da atenção à saúde apareceu a partir da Medicina Comunitária, tendo seus pressupostos reconhecidos como principios básicos de organização dos serviços de saúde em geral. O momeñto expressivo de difusão internacional da Medicina Comunitária ocorreu a partir da Declaração da Conferência de Alma-Ata em 1978, propiciando a reorganização dos serviços de saúde e trazendo a Atenção Primária à Saúde para a esfera da política geral de saúde.

Barrenechea e Uribe (1987) colocaram: " $O$ argumento central do processo que pressupõe "Saúde Para Todos no Ano 2000" é de que se satisfaça as necessidades de diferentes grupos populacionais que integram a sociedade, ocorrendo assim uma diminuição das desigualdades entre estes, com a condição necessária para se resolver os problemas de saúde através de maior participação e eficiência social possivel. Portanto, o objetivo se expressa não somente nas questões da saúde que se deve alcançar, mas principalmente em termos de acesso, uso e organização de serviços de saúde, que conjuntamente com recursos e ações de outros setores econômicos e sociais, satisfaçam as necessidades globais básicas dos diversos grupos humanos que integram as sociedades concretas." Os autores argumentaram ainda que a Atenção Primária se constitui numa estratégia, pois se propõe a diminuir as desigualdades entre diferentes grupos populacionais ao se apropriar, recombinar, reorganizar e reorientar todos os recursos de todo o setor saúde para satisfazer as necessidades de toda a sociedade.

Segundo Gérvas, Pérez Fernandez e Garcia Sagredo (1987) são quatro as características básicas da Atenção Primária à Saúde: longitudinalidade, acessibilidade, integralidade e coordenação. A longitudinalidade é considerada, dentre as quatro caracteristicas, a mais básica, pois depende tanto da instituição, quanto da decisão de seus usuários em utilizá-la regularmente, podendo assim haver um acompanhamento desses ao longo do tempo. A acessibilidade prevê a existência de serviços que são o primeiro contato com o sistema de saúde, sempre que surgir uma necessidade. A Atenção Primária deve 
entäo oferecer serviços eficientes e acessiveis, que sejam reconhecidos como tal pelos usuários. A integralidade é a capacidade da Atenção Primária de resolver a quase totalidade dos problemas da população atendida. Alcançar a integralidade na prática presŝ̀upõe que se supere o vazio entre as necessidades dos usuários e as respostas dos provedores das ações. Para isso, a Atenção Primária à Saúde deve oferecer serviços variados e completos que incluam atividades de promoção de saúde, prevenção de doenças, atenção curativa para as doenças agudas mais comuns e para quase todas as doenças crônicas. A coordenação exige a soma das ações de todos os serviços do sistema de saúde. Para tanto são necessários dois aspectos especificos. O primeiro referese à continuidade, que pode ser dividida em dois pontos: a continuidade dentro do próprio nivel de Atenção Primária, com registro adequado das ações desenvolvidas e também com o mesmo provedor; o outro refere-se à continuidade das ações em diferentes niveis de atenção à saúde, a partir das ações do nivel de Atenção Primária. O reconhecimento das necessidades de saúde é o primeiro passo a ser dado, pois sem a identificação dos mesmos não será possivel assegurar uma coordenação.

Segundo Veras (1988), conceitua-se a Atenção Primária à Saúde como o primeiro nivel de contato da comunidade com o sistema de saúde. Deve ser realizada por meio de ações de saúde no campo da promoção, prevençăo, cura e reabilitação do indivíduo. Colocou ainda a autora que devem ser observados quatro aspectos fundamentais para que se possa alcançar uma expansão da cobertura dos serviços oferecidos: participação comunitária, adaptação das ações às condições da comunidade, hierarquização dos serviços de saúde, planejamento em função da demanda e alcance universal das ações.

Testa (1992) destacou a necessidade de se contextualizar os objetos de trabalho. Afirmou, no entanto, que no caso da Atenção Primária à Saúde, não é possivel utilizarmos o mesmo conceito totalizante para todos os paises. Assim sendo, a contextualização da Atenção Primária à Saúde é dada em primeira instância pelo sistema de saúde em que está inserida. É esse sistema que vai 
concretizar a significação dessa atenção em sua organização setorial. Em outras palavras, o autor afirmou que há um significado concreto para atenção primária, dado pelo sistema de saúde no qual está inserida. E há um outro significado abstrato que corresponde a sua definição ideológica, como a que está documentada pela Organização Mundial de Saúde ao defini-la como uma estratégia para que se alcance "Saúde Para Todos no Ano 2000".

Testa afirmou assim que, para os paises capazes de constituir um sistema de saúde, "a Atenção Primária é o degrau inicial da cadeia de atenção, onde são resolvidos os problemas de menor dificuldade técnica - diagnóstica e terapêutica e se orientam os restantes pelos níveis sucessivos da cadeia." Para tanto, alguns aspectos devem ser observados: deve existir uma rede de estabelecimentos interligados, com procedimentos de referência e de transmissão de informações para que se possa organizar o fluxo de pacientes pelo sistema de saúde. Além disso, é necessária uma organização territorial regionalizada. Ressaltou o autor a necessidade de se ter recursos humanos muito bem qualificados, já que esses profissionais ao recepcionarem os pacientes na porta de entrada do sistema serão os responsáveis pela determinação do rumo desses pacientes no mesmo. Testa afirmou ainda que em paises onde se pressupõe que o sistema seja regionalizado, mas o sistema de referência, não se encontra adequado, a Atenção Primária à Saúde se transforma em atenção primitiva da saúde. Colocou-o como "um sistema de segunda categoria, para uma população idem". $\mathrm{Na}$ falta do sistema de referência a Atenção Primária deixa de ser a porta de entrada, que asseguraria uma assistência adequada, tornando-se o único serviço disponivel para a população. Afirmou ainda que essas condições não permitem que o serviço prestado alcance o nivel necessário.

Segundo Schraiber \& Mendes-Gonçalves (1996) a Atenção Primária à Saúde tem sido associada a uma assistência de baixo custo, por ser considerada simples e com poucos equipamentos. Pode ainda parecer uma organização própria do setor público e voltada a uma "medicina simplificada", de "baixa qualidade". Tal concepção tem origem na sua criação como prestação de 
assistência do serviço público e que tinha como objetivo ampliar a cobertura de serviços para a população mais carente e excluída dos serviços, ampliando a assistência médica de forma simplificada e barata.

Os autores colocaram "ainda que as situações assistenciais da Atenção Primária podem ser consideradas como casos epidemiologicamente complexos do ponto de vista do trabalho profissional, mesmo com patologias consideradas clinicamente simples. Tal fato ocorre pois a Unidade Básica de Saúde foi destinada a estratificar a clientela, agrupando pessoas que se dirigem aos serviços pela primeira vez, devido a alguma demanda especifica. Por ser um primeiro atendimento o serviço será a porta de entrada para o sistema de assistência à saúde. Dentro do sistema, constitui-se como um nivel próprio de atendimento que deve ir resolvendo uma número de necessidades que extrapolam a intervenção curativa individual. Essas necessidades incluem demandas tais como o saneamento do meio, o desenvolvimento nutricional, a vacinação e a informação em saúde, gerando ações tradicionais à saúde pública. Também inclui demandas voltadas à algumas ações clinicas de dois tipos especificamente: prevenção, profilaxia e tratamento de doenças epidêmicas e que necessitam de vigilância epidemiológica; demandas clinicas de prevenção e recuperação, com quadros muito freqüentes e apoiados em técnicas diagnósticas e terapêuticas que necessitam de menor uso de equipamento, mas que exigem para sua adequada compreensão e efetiva transformação uma sintese de conhecimentos além da integração de ações individuais e coletivas, curativas e preventivas, assistenciais e educativas. Uma Unidade Básica de Saúde deve, portanto, apresentar alta capacidade resolutiva e alta sensibilidade diagnóstica, para que seja possivel atuar corretamente nas demandas primárias e propor encaminhamentos adequados no interior do sistema assistencial

Schraiber \& Mendes-Gonçalves (1996) apontaram que ao se pensar em necessidades de saúde é comum a lembrança da "assistência", representada principalmente pela procura de cuidados médicos. Essa procura pode ser caracterizada como demanda e originada pelo carenciamento de algo que o 
individuo percebe que deve ser corrigido - uma alteração física, orgânica ou até mesmo algo não identificado ainda. Essa falta pode inclusive ser de uma informação. As necessidades geram intervenções que também podem ser denominadas como necessidades. Colocaram os autores que: "considerando-se que toda a intervenção só tem existência na sociedade como uma dada produção e distribuição social de serviços, em tal ou qual padrão de serviços articulados entre si (Sistema de Saúde), o modo de organizar socialmente as ações em saúde para a produção e distribuição efetiva dos senviços será não apenas resposta a necessidades, mas imediatamente, contexto instaurador de necessidades."

Os autores colocaram que, ao se estratificar as necessidades em saúde, ocorrerá uma delimitação de quantidades e qualidades nos carenciamentos de uma população e consequentemente isto poderá "significar uma racionalização de formas e conteúdos de intervenção técnica tal que faculte um equilíbrio entre a demanda e os custos dos serviços." A estratificação de necessidades, além da delimitação de patamares que resultam na organização de serviços e que satisfaçam as necessidades conhecidas em cada nivel, pode ir além e conhecer outras necessidades. Essas referem-se às necessidades "não-sentidas", ou seja, pode-se criar espaços de emergência de necessidades. Os autores explicam ainda que: "trata-se de carenciamentos pertencentes à vida cotidiana que, por meio da critica à ciência tradicional e suas técnicas, relacionamos ao adoecer humano e à recuperação, mas que ainda não são considerados deste modo pela ciência tradicional e por isso não estarão já incluídos na produção usual dos serviços e nas ações técnicas conhecidas."

Schraiber \& Mendes Gonçalves (1996) ao se referirem ao patamar de necessidades que querem reconceber, mais especificamente a assistência que se delimita para a unidade básica de saúde e que tratam como "atenção primária", colocaram três pontos a serem discutidos: 
1. Deve-se evitar a redução das necessidades de saúde a processos fisiopatológicos nas concepções dos serviços, valorizando positivamente a Atenção Primária como forma especifica de organizar a prática e portanto, dotada de uma complexidade particular.

2. Deve-se revalorizar a busca por uma assistência progressivamente totalizadora, ao invés da somatória de atos especializados. Dessa forma, a Unidade Básica de Saúde pode se tornar uma instituição com a possibilidade de desenvolver uma assistência mais global, inovadora e tecnologicamente ultramoderna. A inovação e a tecnologia de ponta se referem a novas questões assistenciais voltadas às necessidades não "trabalhadas" do ponto de vista técnico.

3. Deve-se instituir uma dimensão subjetiva das práticas em saúde como parte da inovação tecnológica, "revalorizando, tanto para a população quanto para os médicos e demais profissionais, uma prática cujas relações interpessoais também resguardem o sentido humano das profissões em saúde." Tal visão se contrapõe àquela que acredita na cisão entre o que é técnico-científico e o que é humano nas ações técnicas.

Schraiber \& Mendes-Gonçalves (1996) colocaram ainda que: "o risco da delimitação de patamares assistenciais, que encontra a condição de ser atençãó primária, e, em razão disto, a proximidade que esta atenção estabelece com o viver social cotidiano, exigem o estabelecimento claro de sua forma de assistir e a permanente dúvida de seu acerto. Se com isto se obriga a vir a público os processos de definição/delimitação das necessidades que the são atinentes, possibilitando sua democratização e explicitação ética, traz, de outro lado, a avaliação sistemática da lógica e dos instrumentos desses procedimentos e a publicidade das racionalidades e operações de suas tecnologias assistenciais, igualmente sujeitando-as ao difícil jogo dos interesses divergentes e dos conflitos de projetos sociais diversos. Mais que ousar propor, portanto, é ousar dispor de aberturas tecnológicas em que as proposições políticas e técnicas venham a público para serem refletidas." 
O nivel de Atenção Primária à Saúde mais do que uma estratégia para se dimimuir as desigualdades, mostra-se como um local onde as práticas de saúde podem ser produzidas a partir de novos pressupostos, gerando intervençōes que podem interferir nos diferentes momentos do processo saúde/doença de uma população. Tal tarefa, apesar de parecer simples, mostra-se complexa e ainda carente de reflexōes. O relacionamento entre diferentes profissionais de saúde que juntamente com os usuários do sistema de saúde buscam apreender as necessidades de saúde de uma população, pode se tornar uma tarefa árdua e pouco efetiva se os pressupostos que fundamentam essa prática estiverem pautados em questōes filosóficas e políticas contraditórias e/ou antagônicas. A Atenção Primária à Saúde torna-se, portanto, um local onde a pesquisa sobre a prática profissional se faz necessária e fundamental, buscando-se um novo fazer profissional e não simplesmente uma adaptação ou generalização de modelos ou técnicas aprendidos.

\subsection{A Inserção da Fonoaudiologia Na Esfera Municipal de São Paulo}

A inserção da Fonoaudiologia nos serviços públicos de saúde do Município de São Paulo se deu de uma forma peculiar, tendo se iniciado na área da Saúde, passando em seguida por um longo periodo de atuação voltado à Saúde do Escolar na Secretaria Municipal de Educação, e em 1989 voltando novamente à atuação, sobretudo na saúde, no nível de Atenção Primária.

É por esse motivo que, apesar do objeto desse estudo ser a prática fonoaudiológica nos serviços de Atenção Primária à Saúde, fez-se necessário resgatar a história da assistência prestada aos escolares. Para tanto foram utilizados diversos documentos da Secretaria Municipal de Educação de São Paulo, que relatam essa história. 
As três primeiras unidades de Parques Infantis foram criadas em 1935 com a finalidade de propiciar assistência pré-escolar às camadas mais desfavorecidas da população. A proposta inicial desses Parques Infantis era de proporcionar atividades de Educação Física, recreação e distribuição de um copo de leite por período a cada criança. Para a realização dos Programas de Saúde, em 1936, as unidades passaram a contar com serviços médicos e odontológicos. Em 1937, foram contratados educadores sanitários para acompanharem tanto as crianças dos Parques Infantis, como os adolescentes dos recém-criados Centros de Menores Operários e Centros de Moças. Esse acompanhamento iniciava-se na matrícula, estendendo-se para imunizações, curativos, cursos, orientações a pais, supervisão no preparo e distribuição de merenda e limpeza. Com a publicação em 1937 do trabalho "Vícios e Defeitos da Fala", relativo às crianças de Parques Infantis, surgiu uma preocupação que culminou com a criação de Centros Ortofônicos, cuja finalidade era atuar reeducando os portadores de patologias de Comunicação Oral.(Prefeitura Municipal de São Paulo, 1984a)

Apesar da previsão de construção de mais 46 Parques Infantis, outras obras foram priorizadas; em 1942 o Município de São Paulo contava com apenas sete Parques Infantis.(Prefeitura Municipal de São Paulo, 1984a)

Algumas mudanças ocorreram a partir de 1945: a Secretaria de Cultura e Higiene foi criada através da Lei no. 333 de 27 de Dezembro de 1945. A Divisão de Educação, Assistência e Recreio - DEA- da Secretaria de Cultura e Higiene, foi criada no artigo 3o. do Decreto-Lei no. 360/46, e tinha como incumbência "colaborar na obra de presenvação e de previsão social contribuindo para educar, assistir e recrear as crianças e adolescentes". O Decreto-Lei no. 430 de 8 de Julho de 1947, desdobrou a Secretaria de Cultura e Higiene em duas: Secretaria de Higiene e Secretaria de Educação e Cultura. Esta última com o Departamento de Cultura e Departamento de Educação, Assistência e Recreio. A assistência ao escolar ficou então sob a responsabilidade desse último, ao qual cabia: "1. promover a educação social da infância e do adolescente, aperfeiçoando-os física e intelectualmente; 2 . desenvolver nas crianças e nos 
adolescentes o espirito de cooperação e solidariedade humana; 3. assistir e recrear as crianças; 4. Difundir o ensino primário, vocacional e profissional." (Prefeitura Municipal de São Paulo, 1984a).

$\therefore$

Aos poucos fez-se necessário o desenvolvimento de Programas de Saúde dirigidos às crianças dos Parques Infantis e adolescentes dos Centros de Educação Social, que seriam assistidos sob o ponto de vista médicoodontológico. Como atividade complementar a Prefeitura Municipal de São Paulo iniciou em 1947 o funcionamento do Laboratório de Fonética e Acústica', sendo que educadoras e recreacionistas exerciam a função de Ortofonistas ou Foneticistas com o objetivo de detectar, diagnosticar e corrigir os distúrbios dos órgãos auditivos e fonadores. (Prefeitura Municipal de São Paulo, 1979)

Em São Paulo a Rede Municipal de Ensino se expandia. A partir de 1950, acelerou-se a industrialização, aumentando o ritmo de desenvolvimento da cidade. O crescimento populacional do Município de São Paulo gerou um desafio no que se refere à infra-estrutura necessária para o sistema produtivo, e também para as necessidades da população quanto aos serviços de saúde, educação, moradia, transporte, saneamento e previdência social, que passam a ser sempre insuficientes graças às demandas crescentes. De 1947 a 1955, os Parques Infantis aumentaram para cinqüenta, tendo grande peso politico junto à população. Em 1956, foram criadas trinta e quatro novas unidades.(Prefeitura Municipal de São Paulo, 1984a).

Em 1956, com a criação do Ensino Primário Municipal, o atendimento odontológico dos alunos mais carentes era realizado nos Consultórios Odontológicos dos Parques Infantis. No entanto os Parques Infantis passaram a perder seu peso político, uma vez que o ensino primário passou a receber mais atenção e recursos. As atenções em saúde foram transferidas aos alunos das

\footnotetext{
'Segundo Figueredo Neto (1988) o Laboratório de Fonética e Acústica realizou estudos nas áreas de Lingüistica, Acústica da Fala e Ambiente, além de seus profissionais atuarem na correção de defeitos da voz e da fala, principalmente com escolares. O Laboratório era responsável ainda pelo controle de ruidos urbanos. Comenta a autora que esta foi a primeira iniciativa oficial na cidade de São Paulo a cuidar da correção de defeitos da voz e da fala.
} 
Escolas Municipais de Primeiro Grau, inclusive com a construção de Consultórios Odontológicos nas unidades escolares criadas.(Prefeitura Municipal de São Paulo, 1984a)

Em 1957, com a transferência de quase todos os médicos da Secretaria de Educação para a Secretaria de Higiene e Saúde, devido à epidemia de "gripe asiática" que se alastrou no Município, apenas três médicos restaram na Secretaria de Educação e Cultura, defasando-a ainda mais. (Prefeitura Municipal de São Paulo, 1984a)

Em 1965, com o aumento de número de profissionais e de especialistas que atuavam já com caracteristicas de equipe multiprofissional de Saúde Escolar, criou-se a Clínica Odontológica Especializada, com o objetivo de atender aos alunos da Rede Municipal nas especialidades de Radiologia, Cirurgia e Ortodontia.

O grande indice de retenção e evasão dos alunos da rede municipal de ensino fez com que a Secretaria Municipal de Educação e Cultura resolvesse então oferecer aos educandos novas condiçōes de atendimento e criasse em 1967, por meio da Lei 7.037, o Departamento de Assistência Escolar - DEA. No quadro desse Departamento havia Médicos, Dentistas, Psicólogos, Fonoaudiólogos, Educadores em Saúde e Nutricionistas. Nessa época também já funcionavam nos bairros do Itaim e da Móoca duas Clínicas Psicológicas que foram criadas com o objetivo de atender "o acréscimo da demanda de escolares com problemas de comportamento ou distúrbios da fala e audição."

Os Fonoaudiólogos que então atuavam no Laboratório de Fonética e Acústica foram transferidos para atuarem com as crianças da Rede Municipal de Ensino que portavam patologias da comunicação, desenvolvendo suas atividades nas duas Clínicas Psicológicas. (Prefeitura Municipal de São Paulo, 1988) 
Em 1969, uma época politicamente marcada pelos Atos Institucionais nos. 1, 2, 3, 4 e 5, havia a repressão e a recessão; na área da Educação foram evidenciadas mudanças de caráter administrativo, pedagógico e político. Apesar disso, uma série de pesquisas médicas, odontológicas, de comunicação, orientação, treinamentos e outras atividades foram desenvolvidas visando à Saúde Escolar, que é enfocada "segundo ações em função dos aspectos de ambiente escolar saudável, serviços de saúde e ensino de saúde, porém a preocupação é ainda assistencialista". Essa tendência predominou ainda na década de 70. (Prefeitura Municipal de São Paulo, 1984a)

Em 1979, por meio da Portaria no. 477/79, o Departamento de Assistência Escolar, pela primeira vez, mostrou uma "preocupação com a prevenção de anomalias fisicas ou mentais; com a integração e colaboração com os órgãos da Secretaria de Educação, apesar de priorizarem a assistência médico-odontológica e alimentar aos educandos, mostrando que a abordagem de cunho 'preventivo', por outro lado corresponde à orientação assistencialista que predomina nos órgãos públicos ligados à promoção social.".(Prefeitura Municipal de São Paulo, 1984a).

Em setembro de 1980 foi contratado o primeiro profissional Fonoaudiólogo para a Secretaria Municipal de Saúde. Esse profissional foi contratado para atuar dentro do Hospital Infantil Menino Jesus, onde iniciou o Setor de Fonoaudiologia. $^{2}$

Em maio de 1981 a Lei no. 9.265 criou além da Seção de Compras a Seção de Fonoaudiologia, que substituiu o Laboratório de Fonética e Acústica. Em julho de 1981 o Decreto-Lei no. 17.429 alterou o Departamento de Assistência Escolar para Departamento de Saúde Escolar - DSE. (Prefeitura Municipal de São Paulo, 1984a)

\footnotetext{
${ }^{2}$ Esta informação foi obtida por meio de relato pessoal.
} 
No organograma do Departamento de Saúde Escolar, a Seção de Fonoaudiologia estava diretamente ligada à Divisão de Assistência Médica. Além da Seção de Fonoaudiologia havia: a Seção de Clínica Médica Geral, Seção de Clínica Médica Especializada, Seção de Educação Sanitária, Seção de Psicologia, Serviço de Clínica do Itaim, Serviço de Clínica da Móoca e Serviço de Psicologia Escolar. Havia ainda no organograma a Divisão de Assistência Odontológica e a Divisão Administrativa. O Serviço de Fonoaudiologia atendeu a crianças encaminhadas para um trabalho de aperfeiçoamento dos padröes da fala e voz, totalizando 5.771 tratamentos.(Prefeitura Municipal de São Paulo, 1984a).

Em 1982, para acompanhar o desenvolvimento do municipio, são instaladas cinco mini-clínicas, denominadas Clínicas de Saúde Escolar. Tinhamos nessa época portanto, um total de sete Clínicas que prestavam assistência na Saúde Escolar.(Prefeitura Municipal de São Paulo, 1984a).

Ainda em 1982, mais dois profissionais Fonoaudiólogos são incorporados ao corpo de especialistas do Hospital Infantil Menino Jesus, para atuarem especificamente no Setor de Audiologia Clínica avaliando a audição de crianças. ${ }^{3}$

Em 1983, o Dr. Hélio Maciel, então diretor do Departamento de Saúde Escolar, elaborou e imprimiu um documento através da Secretaria Municipal de Educação, com uma visão histórica da Saúde do Escolar no Contexto da Educação no Municipio de São Paulo:

"De acordo com a opinião de técnicos no assunto, o enfoque à ser dado à problemática da
saúde não pode e não deve ser confundido com o dirigido à problemática da doença. Com
base nesta filosofia de trabalho é que o DSE vem orientando sua ação, muito mais voltada
para o aspecto de promoção da saúde das crianças. Outro ponto a ser esclarecido é que
Saúde do Escolar como um aspecto de Saúde Pública, não se faz visando individuos, mas
uma comunidade toda; assim sendo o DSE encara sua clientela como todo, procurando
dar soluçöes adequadas para aqueles problemas que realmente afetam uma parte
significativa da população escolar. Finalmente, o planejamento de um programa de Saúde
Escolar que realmente atenda às necessidades da população a que se destina deve basear-
se no conhecimento dessa população. Por esse motivo, o DSE vem, gradativamente,
desenvolvendo atividade, estudo e pesquisas que lhe permitam conhecer a sua clientela,
suas caracteristicas básicas, suas necessidades e seu potencial, articulando

${ }^{3}$ Esta informação foi obtida por meio de relato pessoal 
programações especificas de atendimento para cada problema considerado relevante. A partir desses parâmetros, que retratam a realidade da clientela do DSE, foi que se criou escala de prioridade, orientando o planejamento do Programa de Saúde Escolar."(Prefeitura Municipal de São Paulo, 1984a)

Os programas do Departamento de Saúde do Escolar em 1983 tinham como objetivos: inspeção médica para fins de Educação Fisica; assistência médica a pré-escolares e escolares do 10. grau; assistência oftalmológica; vacinação; controle e notificação de doenças transmissiveis; assistência odontológica preventiva, curativa, de forma rotineira e especializada; assistência psicológica; assistência alimentar; assistência fonoaudiológica; educação em saúde; assistência à saúde do professor (proteção contra rubéola).

O Departamento de Saúde Escolar, com suas sete clínicas, em 1984 mantinha serviços de terapia e consultas para especialidades ainda não existentes em número suficiente para atender a comunidade, tais como 0 tratamento psicológico, fonoaudiológico, consultas oftalmológicas e tratamento neuropsiquiátrico.

Segundo documento da Prefeitura Municipal de São Paulo (1984b), a Assistência Fonoaudiológica tinha como objetivo a "prevenção, avaliação e correção de problemas no que se refere à área de comunicação escrita e oral, fala e audição, utilizando métodos e técnicas fonoaudiológicas." Para que estes objetivos pudessem ser alcançados, preconizava-se que os fonoaudiólogos do Departamento de Saúde Escolar trabalhassem "em estreita relação com os demais técnicos de Educação do Departamento de Planejamento e Orientação, pois a prevenção de problemas fonoaudiológicos se inicia desde o planejamento das técnicas pedagógicas." Os fonoaudiólogos do Departamento de Saúde Escolar deveriam ainda acompanhar o processo educacional dos alunos portadores de patologias fonoaudiológicas, propiciando a interação da terapia com o trabalho do professor na escola.

Ainda segundo o mesmo documento as atividades de saúde desenvolvidas pelo Departamento de Saúde Escolar visavam a prevenção de doenças e a 
promoção de saúde de Pré-Escolares de 3 a 7 anos de idade das Escolas Municipais de Educação Infantil (EMEI), das classes de pré-escola, dos escolares de 7 a 14 anos de idade das Escolas Municipais (EM), da Escola Municipal de Deficientes Auditivos (EMEDA) e dos alunos dos cursos de Ensino Supletivo (EMES).

Segundo relatório apresentado pela Seção de Fonoaudiologia sobre os anos de 1986 a 1988, (Prefeitura Municipal de São Paulo) no final de 1985, 46 Fonoaudiólogos atuavam junto ao Departamento de Saúde Escolar. Tinham como objetivo :

"Atuar no processo educacional minimizando alguns dos fatores interferentes na relação ensino-aprendizagem, prevenindo e reabilitando os Distúrbios da Comunicação Oral e Gráfica dos alunos da Rede Municipal de Ensino, orientando e subsidiando pais, professores e equipes multidisciplinares."(Prefeitura Municipal de São Paulo, 1984b).

A reorganização do Departamento de Saúde Escolar ocorreu novamente em 7 de Novembro de 1988 mediante a Lei 10.675, criando cargos e reestruturando carreiras. O artigo 50 dessa Lei institui a carreira de Fonoaudiólogo para a Prefeitura Municipal de São Paulo, com 264 profissionais, sendo que 120 destes, do Departamento de Saúde Escolar. Nessa reestruturação, o novo organograma conta com a Divisão Administrativa, Divisão de Odontologia, Divisão Médica, Divisão em Saúde e Educação, Divisão de Psicologia e Divisão de Fonoaudiologia que inclui a Seção de Fonoaudiologia Clínica e a Seção de Fonoaudiologia Escolar. As Divisões estavam diretamente ligadas à Assistência Técnica, Equipe Técnica de Planejamento e Pesquisa e Setor Técnico de Epidemiologia e Estatistica. As Clínicas de Saúde Escolar, dez nessa época, ficaram subordinadas à Divisão Administrativa, e a subordinação técnica dos profissionais ficou a cargo das Divisões Técnicas correspondentes, uma vez que as Clínicas dispunham de equipe multiprofissional. (Prefeitura Municipal de São Paulo, 1989). 
A Seção de Fonoaudiologia Clínica justificava-se pela ocorrência significativa de distúrbios da fala e de linguagem, que poderiam acarretar problemas secundários na área educacional. Justificava-se, assim, um atendimento clínico, com programa de diagnóstico para fins terapêuticos por meio de atendimento individual ou em grupo de alunos, além da orientação para os pais e para as escolas. Já a orientação fonoaudiológica escolar visava promover atendimento a professores, orientando-os nas dificuldades específicas do desenvolvimento da fala e/ou linguagem, e na sensibilização e acompanhamento fonoaudiológico de escolares por meio de atuação de profissionais da área nas Delegacias Regionais de Escolas Municipais - DREMs - fornecendo técnicas e subsídios que visavam avaliar e prevenir os distúrbios da comunicação.(Prefeitura Municipal de São Paulo, 1989).

No entanto, uma nova proposta foi formulada ainda em 1988: "Em Saúde, a nova proposta é unificar as ações de saúde através de uma única secretaria Secretaria Municipal de Saúde - e com ações dirigidas a todos os indivíduos e não só a certos segmentos da população." (Prefeitura Municipal de São Paulo, 1989)

Assim, segundo documento do Departamento de Saúde Escolar (Prefeitura Municipal de São Paulo 1989), no dia 21 de Março de 1989, foi assinado o Decreto no. 27.695 transfirindo o Departamento de Saúde do Escolar, da Secretaria Municipal de Educação, para a Secretaria Municipal de Saúde. Essa decisão, tomada em conjunto pelas duas Secretarias, teve como base "a necessidade de organizar os serviços de saúde de forma descentralizada, racionalizando recursos e atividades, sob gerenciamento único e competência do Poder Público, visando a elaboração e consecução do Sistema Único de Saúde SUS - em nível municipal. Esta medida integra o projeto de unificação dos vários órgãos municipais que atuam na área de prestação de serviços públicos de saúde, alocando seus recursos de modo a contemplar as necessidades de assistência detectadas no seio da população, na forma de Administrações Regionais de Saúde." 
Ainda segundo o documento de 1989, o novo modelo exigia o desenvolvimento de atividades que permitam uma avaliação dos determinantes da saúde e da doença existentes na área de influência das Unidades Básicas de Saúde - UBS - e que acabam por se concretizar nos locais de trabalho, de estudo e de lazer.

"A atenção integral à criança $e$ ao adolescente deveria ter como objetivo a possibilidade de interferir na qualidade de vida do individuo, visando a sua realização enquanto cidadão, ou seja, não apenas para que ele aprenda, mas para que ele possa se manifestar socialmente de forma plena... Assumir a saủde integral da criança e do adolescente, escolar ou não, significa englobar medidas dirigidas tanto a questōes coletivas como à assistência individual." (Prefeitura Municipal de São Paulo, 1989).

A partir dessas mudanças, os Fonoaudiólogos que antes atuavam nas Clinicas de Saúde Escolar, e outros duzentos profissionais concursados em 1989, passaram a fazer parte da equipe de profissionais que atuavam na Secretaria Municipal de Saúde, sendo que a grande maioria deles acabou por se inserir nas Unidades Básicas de Saúde, no nivel de Atenção Primária, atendendo à política proposta acima, e que visava à atenção integral à saúde do indivíduo. Aqueles profissionais que haviam sido contratados sem concurso também participaram desse processo, e foram efetivados como Fonoaudiólogos dos quadros da Prefeitura Municipal de São Paulo.

Dessa forma, pode-se dizer que apesar de ter sua prática voltada para a saúde do escolar desde as décadas de 20-30, o Fonoaudiólogo tem sua inserção, com um número de profissionais significativo, atuando em Unidades Básicas de Saúde no nivel de Atenção Primária à Saúde, na Prefeitura Municipal de São Paulo, a partir de 1989. 


\subsection{A Inserção da Fonoaudiologia na Esfera Estadual de São Paulo}

A falta de documentos que descrevam a inserção da Fonoaudiologia nos serviços públicos de saúde, lẹvou-nos a percorrer a história de formas diferentes, na tentativa de reconstrui-la. Uma das formas foi a coleta de depoimentos de profissionais que de fato contribuiram para o início da inserção da Fonoaudiologia nesse contexto. Outra forma, foi a busca através da Coordenadoria de Recursos Humanos da Secretaria de Estado da Saúde, das documentações existentes no que se refere às contrataçōes realizadas.

Assim sendo, a primeira inserção de um profissional Fonoaudiólogo em Unidades Básicas de Saúde se deu no Centro de Saúde Escola Geraldo Paula Souza, vinculado à direção da Faculdade de Saúde Pública da Universidade de São Paulo. Tal fato ocorreu em 1972, dada a necessidade de se realizar exames visuais, quando foi contratada uma técnica em ortóptica, que tinha como formação universitária a Fonoaudiologia. Essa profissional, devido a sua formação, iniciou um trabalho voltado para a Fonoaudiologia, tendo sido seu cargo logo transferido para Técnico em Fonoaudiologia.

Em 1974, uma aluna da Pontifícia Universidade Católica de São Paulo realizou um estágio de um ano junto com a profissional citada no Centro de Saúde Geraldo Paula Souza. Em 1977, por motivos pessoais, a profissional transferiu-se do municipio de São Paulo, tendo a sua ex-estagiária, nessa época já formada, assumido seu cargo naquela unidade de saúde. A princípio, sua substituição deu-se informalmente, com trabalho voluntário por um periodo de 7 meses, para então ser contratada ainda como Técnica em Fonoaudiologia. Somente em 1978 essa profissional obteve o cargo de Fonoaudióloga, até 1986, quando também por motivos pessoais transferiu-se de São Paulo. Durante sua atuação no Centro de Saúde Escola Geraldo Paula Souza, realizou atendimentos fonoaudiológicos e participou, assim como sua antecessora, do "Projeto Escola" que visava atingir crianças da primeira série do primeiro grau para realização de triagem auditiva e de linguagem. 
No ano de 1983, esta profissional foi solicitada a colaborar na escolha dos profissionais Fonoaudiólogos que estavam sendo selecionados para atuarem em Ambulatórios de Saúde Mentalal, numa ação multidisciplinar. Iniciou-se então, o processo de novas contratações de Fonoaudiólogos.

Analisando as fichas de contratações da Coordenadoria de Recursos Humanos da Secretaria de Estado da Saúde, foram preenchidas, em caráter temporário, duas vagas para Fonoaudiólogos, a pedido da Coordenadoria de Saúde Mental, no ano de 1975.

A partir de 1982, um grupo de 11 Fonoaudiólogos (Grupo de Fonoaudiologia Montoro) que participava do Grupo de Saúde do então candidato a governador do Estado de São Paulo, André Franco Montoro, iniciou a discussão e elaborou um Projeto Piloto de Fonoaudiologia em Saúde Pública. Tal projeto acabou por ser aprovado na Secretaria de Estado da Saúde em 1984 $e$ após a aprovação do governador, teve o início de sua implantação em outubro de 1985. Iniciou-se esta implantação pelos Municipios de Embu, Cotia e Vargem Grande da Serra. Em Março de 1987, o Projeto foi implantado também nos Municipios de Itapecerica da Serra e Taboão da Serra. ${ }^{4}$

Os locais de início para implantação do projeto foram escolhidos por apresentarem as condições imediatas para tanto. A região contava com uma equipe multiprofissional atuando dentro de um planejamento integrado, e os Fonoaudiólogos atuariam inseridos nessa equipe. O Grupo de Fonoaudiologia considerava importante a inserção do projeto em um Distrito Sanitário Escola, visando a formação de um Centro de Formação de Fonaudiologia em Saúde Pública.

$\mathrm{Na}$ época da apresentação do projeto, o Grupo de Fonoaudiologia que fazia parte do grupo de Saúde Montoro redigiu uma justificativa cuja introdução

\footnotetext{
${ }^{4}$ As informações foram obtida por meio de relato pessoal.
} 
mostrava a necessidade da utilização de serviços de Fonoaudiologia pela população, devido a alta incidência de alterações de Comunicação Oral e Escrita. 0 relato mostrou ainda que na esfera Federal não haviam Fonoaudiólogos prestando serviços, seja no Ministério da Saúde, seja no Ministério da Educação e Cultura. Já na esfera Estadual, não havia Fonoaudiólogos atuando nos hospitais mantidos pela Coordenadoria de Assistência Hospitalar, nem na rede dos Centros de Saúde. Apenas os hospitais ligados ao Ensino, como Hospital das Clínicas, Hospital São Paulo, Hospital do Servidor Público Estadual, Hospital Regional de Sorocaba, Irmandade da Santa Casa de Misericórdia de São Paulo e Centro Comunitário de Saúde Mental, era possivel encontrar um número restrito de Fonoaudiólogos

Nessa época, faziam parte dos quadros da Secretaria de Estado da Educação quatro Fonoaudiólogos que atuavam na Coordenadoria de Ensino e Normas Pedagógicas e no Departamento de Assistência ao Escolar. Comentaram as autoras que esses quatro Fonoaudiólogos, no entanto, não exerciam cargos em Fonoaudiologia, pertencendo aos quadros da Secretaria, pois também eram professores.

Mesmo no que se refere ao setor privado, o Projeto de Fonoaudiologia mostrou a precariedade na prestação de serviços em Fonoaudiologia, uma vez que havia serviços de Audiologia Clínica para avaliação da audição em alguns hospitais credenciados pelos INAMPS, e também em número reduzido nas empresas de Medicina de Grupo. Concentrava-se assim, a prática fonoaudiológica em consultórios particulares a que, pelo seu custo, apenas uma parcela da população teria acesso.

Mesmo as entidades filantrópicas, que prestavam assistência fonoaudiológica na época, tinham como objetivo o atendimento voltado ao indivíduo excepcional, como no caso da APAE e AACD, pioneiras inclusive na prestação de serviços em Fonoaudiologia. 
Com esses argumentos, o Projeto de Fonoaudiologia considerou "como proposição de princípio, que serviços de saúde de qualidade adequada e em sua concepção mais ampla de prevenção, diagnóstico e recuperação, devem atingir a todas as camadas da população, tornando-se preemente medidas que viabilizem o acesso da população ao atendimento fonoaudiológico.

A pesquisa realizada na Coordenadoria de Recursos Humanos mostrou que em 1983 e 1984 muitos Fonoaudiólogos foram solicitados para atuarem em várias unidades da Divisão de Ambulatórios de Saúde Mental. Em 1983 foram os seguintes Ambulatórios de Saúde Mental que publicaram suas necessidades de Fonoaudiólogo: Centro, Perdizes, Santo Amaro, Belenzinho, Água Funda, Mandaqui, Osasco, Pirituba, São Miguel Paulista e São Bernardo do Campo. Em 1984 foram requisitados Fonoaudiólogos para os Ambulatórios de Saúde Mental do Jaçanã, Franco da Rocha, Vila Brasilândia, Itaquera, Vila Matilde, Taboão da Serra, São Mateus, Mogi das Cruzes, Lapa, Largo 13 e Mauá.

A proposta de trabalho para equipes multidisciplinares em unidades básicas e em ambulatórios de saúde mental foi redigida e apresentada em 1983, pela Coordenadoria de Saúde Mental da Secretaria de Estado da Saúde de São Paulo, e esclarece a contratação dos Fonoaudiólogos para esses ambulatórios. Aos Ambulatórios era designada uma assistência secundária por meio de profissionais de áreas diversificadas, e com açōes mais complexas e individualizadas. O documento descrevia que em uma Unidade Básica de Saúde deviam ser desenvolvidos os tratamentos mais breves, de preferência em grupos. Para o Ambulatório ou Hospital da região deviam ser encaminhados os pacientes que necessitassem de atendimento não oferecido pelas Unidades Básicas, como no caso da Fonoaudiologia e Terapia Ocupacional, além dos atendimentos mais longos e individualizados. A Equipe Multiprofissional do Ambulatório de Saúde Mental deveria contar com psiquiatra, psicólogo, assistente social, enfermeiro, terapeuta ocupacional, fonoaudiólogo, farmacêutico, visitador domiciliar e atendente de enfermagem, além do pessoal administrativo. (Secretaria de Estado da Saúde de São Paulo, 1983). 
Em 1985 podia-se constatar a contratação de Fonoaudiólogos para unidades de saúde no Escritório Regional de Saúde - 12, mas sem especificar qual a unidade que contaria com o profissional. Ainda em 1985 houve a necessidade do Fonoaudiólogo no Ambulatório de Saúde Mental de Sorocaba.

Em 1986, os registros da Coordenadoria de Recursos Humanos apontavam a necessidade de Fonoaudiólogos no CSIl de Cubatão, no Ambulatório de Saúde Mental de Cubatão e no Hospital Guilherme Álvaro, todos no litoral. Havia ainda o registro de solicitação de um Fonoaudiólogo em Marilia para o Escritório Regional de Saúde, sem especificar a atividade para a qual seria designado. Ainda em 1986 foi realizada a requisição de um Fonoaudiólogo para o Ambulatório Regional de Saúde Mental de Ribeirão Preto.

Em 1987 iniciou-se um aumento de Fonoaudiólogos para atuarem em Centros de Saúde, havendo o registro para Itapecerica da Serra, Taboão da Serra, São Bernardo do Campo, Tucuruvi, Vila Maria e Santana. O Fonoaudiólogo requisitado para atuar em Santana estaria envolvido com a área de Saúde do Trabalhador. Essa influência talvez tenha se dado graças ao início de um estágio curricular de alunos do $4^{\circ}$ ano da Pontifícia Universidade Católica de São Paulo, na área de Saúde do Trabalhador, e que demandou nessa época a contratação de um profissional da própria Secretaria de Estado da Saúde. Foram ainda solicitados Fonoaudiólogos para atuarem em Bauru, Taubaté e Ambulatório de Saúde Mental de Ribeirão Preto

O relato dos Fonoaudiólogos que iniciaram o Projeto de Fonoaudiologia e os dados encontrados na pesquisa realizada junto a Coordenadoria de Recursos Humanos mostram o início da contratação de Fonoaudiólogos para atuarem nos serviços públicos de saúde na esfera estadual.

Em 1988 foram encontrados 18 registros que solicitavam Fonoaudiólogo sem especificarem a sua atividade, alocando-os nos Escritórios Regionais de 
Saúde tanto da Capital como do Interior. Tais profissionais podem estar atuando tanto em Unidades de Saúde, como em Ambulatórios de Saúde Mental. Foram ainda convocados 10 Fonoaudiólogos para atuarem em Centros de Saúde, principalmente da Grande São Paulo e Interior, 4 Fonoaudiólogos para atuarem em Ambulatórios de Saúde Mental e um Fonoaudiólogo para atuar em um Complexo Hospitalar.

Em 1989 foram contratados 23 Fonoaudiólogos e quase todos para atuarem em Unidades Básicas de Saúde da Capital, Grande São Paulo e Interior.

Essa pesquisa nos registros da Coordenadoria de Recursos Humanos nos mostrou uma maior concentração de Fonoaudiólogos atuando em Unidades Básicas de Saúde portanto, principalmente entre 1987 e 1989, no nivel de Atenção Primária à Saúde. Os anos posteriores não foram pesquisados, uma vez que nosso interesse estava no início da prática fonoaudiológica, principalmente nas Unidades Básicas de Saúde.

É interessante notar o movimento que mostra a inserção do Fonoaudiólogo no nivel de Atenção Primária à Saúde no municipio de São Paulo. Após o inicio na área da Educação, o Fonoaudiólogo inicia sua inserção na área da saúde por meio de uma atuação clínica/hospitalar e posteriormente como parte de equipe multiprofissional em um projeto em saúde mental. Além disso, a militância politica de alguns profissionais possibilitou que um projeto de Fonoaudiologia na saúde pudesse ser desenvolvido. Podemos notar o início de um processo, por meio do qual o Fonoaudiólogo procurava, concomitantemente, mostrar sua especificidade enquanto profissional da saúde e buscar a metodologia ou a forma de desenvolver ações que não tivessem um caráter exclusivamente clínico. No entanto, é a mudança na política de saúde proposta por gerentes de saúde do município em 1989 que propicia ao Fonoaudiólogo uma inserção em número mais significativo, principalmente no nível de Atenção Primária. 
Em 1996, mudanças na política de saúde no município de São Paulo novamente transformaram a inserção e a prática fonoaudiológica na área da saúde sob responsabilidade do município. A implantação do Plano de Atendimento à Saúde (PAS), pela Prefeitura Municipal de São Paulo, modificou o panorama apresentado substanciaimente. A partir da transferência do gerenciamento da saúde à um sistema de cooperativas privadas, boa parte dos profissionais concursados e contratados foram transferidos para as Secretarias de Educação e Bem-Estar Social, encerrando suas atividades tanto no nivel de atenção primária como nos outros niveis. Poucos profissionais ainda se mantêm na área da saúde, atuando em programas específicos como Saúde do Trabalhador e AIDS. A. Ainda não foi possivel analisar criteriosamente as conseqüências da implantação do PAS no município de São Paulo com relação à Fonoaudiologia. No entanto, numa primeira análise, acredita-se que mudanças significativas já devam estar ocorrendo, partindo-se do pressuposto que o referido plano. tem um número menor de Fonoaudiólogos atuando e que as caracteristicas da assistência prestada aos usuários são diferentes daquelas até então entendidas para a Atenção Primária à Saúde.

\subsection{A LIteratura em Fonoaudiologia e Saúde}

As primeiras referências brasileiras que descreveram a prática fonoaudiológica em serviços públicos de saúde datam do início dos anos 80 . Destacam-se ai aquelas apresentadas no 1 Encontro Nacional de Fonoaudiologia ${ }^{5}$.

O primeiro artigo encontrado, de Sampaio e Gonçalves (1980), apresentou a ação fonoaudiológica no campo da Saúde Pública, mais voltada para crianças, principalmente pré-escolares e escolares. Apresenta uma forma de ação pautada

\footnotetext{
${ }^{5}$ O I Encontro Nacional de Fonoaudiologia foi realizado em novembro de 1982 com promoção do Departamento de Distúrbios da Comunicação da Pontifícia Universidade Católica de São Paulo. Tinha como objetivo criar um espaço para a reflexão sobre a formação e atuação do Fonoaudiólogo no Brasil.
} 
nos conceitos de prevenção primária, secundária e terciária. Naquele momento os autores propunham a estimulação para policarenciados como prevenção primária, o diagnóstico precoce e tratamento imediato na prevenção secundária e a reabilitação na prevenção terciária.

Amaral (1982) relatou sua experiência em um Centro de Saúde no Município de São Paulo. Colocou como responsabilidade dos Centros de Saúde zelar pela saúde dos indivíduos de uma região, propiciando a todos o bem estar físico, mental e social. Admitiu que a sua tarefa principal seria portanto a prevenção de quaisquer distúrbios ou problemas que pudessem ocorrer. Acreditava a autora que na Saúde da Criança é que o Fonoaudiólogo encontraria um vasto campo de atuação, que ainda deveria ser explorado. Relatou, portanto, sua experiência desde 1972 mostrando a outros profissionais da área da saúde a importância da prevenção de problemas de linguagem e audição. Descreveu a atuação voltada para a triagem de audição e linguagem das crianças usuárias daquele serviço de saúde e 0 encaminhamento para tratamento otorrinolaringológico daquelas que necessitavam. Além disso, aquelas que precisavam de atendimento fonoaudiológico poderiam obtê-lo na própria unidade de saúde, com formandas em Fonoaudiologia. Descreveu ainda o desenvolvimento do "Projeto-Escola" com o objetivo de realizar triagens auditivas e de linguagem na própria escola, para posterior orientação a pais e professores. Apresentou o Curso de Orientação sobre a Saúde da Criança, com 04 horas, que tinha como conteúdo o desenvolvimento e estimulação da linguagem e audição. A autora analisou que muito tempo de um profissional especializado foi gasto avaliando a linguagem de crianças que não apresentavam nenhum distúrbio. Assim sendo antecipou um projeto em que a Pediatria do Centro de Saúde estaria orientando os pais, e a Fonoaudiologia serviria de retaguarda para aqueles casos necessários.

Siqueira, Amaral, Oliveira e Bertagnon (1983) apresentaram o campo de trabalho da Fonoaudiologia no I Congresso Paulista de Saúde Pública e I 
Congresso Nacional da $\mathrm{Abrasco}^{6}$. Os autores apontaram para o número de distúrbios da audição (cerca de 10\%) e distúrbios de linguagem (25\%) encontrados em crianças de 1 a 14 anos de idade. Tais índices apontaram para uma preocupação na área da saúde, no que se refere as conseqüências que esses distúrbios poderiam acarretar na escolaridade dessas crianças.

Os dois artigos acima apresentados mostraram ainda uma preocupação com o levantamento epidemiológico dos distúrbios da comunicação encontrados. Ou seja, foram ainda apresentadas as freqüências com que ocorreram e foram atendidos no Centro de Saúde os distúrbios de fala, linguagem e audição.

Andrade e Migliorini(1982) apresentaram no I Encontro Nacional de Fonoaudiologia um discurso histórico e teórico sobre a saúde, ressaltando o enfoque curativo que a medicina praticava no inicio do século $X X$. Mostraram ainda a definição de Saúde apresentada pela Organização Mundial de Saúde que diz: :"Saúde é o completo bem-estar físico, mental e social do indivíduo e não só a ausência da doença". Complementam as autoras que: "a saúde é um sistema dinâmico e que o indivíduo deve ser considerado totalidade, sendo que a qualidade de sua interação com o meio ambiente será determinante do seu nivel de saúde. A saúde é um sistema dinâmico porque baseia-se na interação continua do homem com seu meio ambiente. A doença não se instala de repente. É preciso que estejam presentes três fatores que são: o agente da doença, o hospedeiro humano e fatores ambientais que estimulem a doença.". Apresentaram em seguida a história natural da doença com o objetivo de mostrar conceitos relacionados à promoção da saúde, proteção especifica e prevenção de doenças; ou seja, a prevenção primária, secundária e terciária. As autoras apresentaram a Saúde Pública como um campo de conhecimento em que tanto medidas preventivas como curativas devem ser desenvolvidas em uma população. Apontaram ainda a necessidade de um trabalho multidisciplinar, em que a Fonoaudiologia ainda não havia sido incluída. Justificaram por outro lado, que a formação do Fonoaudiólogo estava mais voltada para a atuação individual

\footnotetext{
${ }^{6}$ Associação Brasileira de Pós-Graduação em Saúde Coletiva.
} 
ou em pequenos grupos de pacientes, com uma visão basicamente reabilitadora, o que traria como decorrência um pequeno alcance de técnicas fonoaudiológicas em termos populacionais. Finalmente, compararam o campo de atuação do Fonoaudiólogo no setor público e privado, buscando mostrar a necessidade de melhoria na formação no que se refere aos conhecimentos em saúde pública, uma vez que maior ênfase tem sido dada à formação para a clínica individual.

Os artigos encontrados e apresentados acima mostram as primeiras produções científicas de profissionais que atuavam como Fonoaudiólogos em Unidades Básicas de Saúde. As experiências vividas foram repensadas e modificadas na tentativa de se alcançar o maior número de pessoas por meio das açōes, levantando prioridades para aquele momento histórico, já que outras experiências no nivel de Atenção Primária nunca tinham sido apresentadas.

Logo em seguida, surgiram as produções teóricas que tinham como objetivo introduzir a discussão sobre a formação e a prática fonoaudiológica para atuação no campo da saúde pública, trazendo como modelo o pensamento preventivo de hierarquização de ações a serem desenvolvidas a partir da História Natural da Doenças. A saúde e a doença são apresentados como um sistema dinâmico e as ações divididas nos niveis de prevenção primária, secundária e terciária. A crítica surge principalmente quanto a formação do Fonoaudiólogo, mais voltada para a reabilitação dos distúrbios da audição e linguagem, ou seja para os aspectos clínicos e numa perspectiva de assistência individual. A especificidade da profissão criada com o objetivo principal de prestar assistência voltada à correção desses distúrbios mostra uma coerência com a formação oferecida. Apesar de existirem diferenças na formação, graças à inserção desses cursos na área biológica - junto às faculdades de Medicina, ou na área de humanas - junto aos centros de Psicologia ou Educação, os Cursos de Fonoaudiologia propiciavam aos seus alunos uma formação mais voltada à reabilitação dos Distúrbios da Comunicação. 
A inserção do Fonoaudiólogo na saúde, nos diversos niveis de atenção passaram a ter influência na formação dos Fonoaudiólogos, ocorrendo inclusive modificaçōes nas grades curriculares com inclusão de disciplinas voltadas à prática desses profissionais,em serviços públicos de saúde.

Andrade, Lins, Marchi e Schochat (1988), a partir de documento ${ }^{7}$ elaborado pelo Conselho Regional de Fonoaudiologia $2^{\mathrm{a}}$ região, discorreram sobre as ações básicas de saúde em Fonoaudiologia. Iniciaram sua argumentação colocando que o campo de atuação mais conhecido desse profissional é no nivel terciário de atenção à saúde, ou na reabilitação. Os niveis primários e secundários iniciaram naquela época um movimento em direção ao reconhecimento do papel do Fonoaudiólogo nesses locais de atuação. Apesar de saberem que as estatísticas voltadas para os distúrbios da comunicação deixavam a desejar, sugeriram que a prevalência desses distúrbios eram preocupantes. Apontaram no final do relatório para a necessidade de inserção do Fonoaudiólogo como profissional do sistema de saúde, e em número suficiente para atender as demandas tanto no nivel de atenção primária, como secundária e terciária.

O Encontro Nacional de Fonoaudiologia Social e Preventiva ${ }^{8}$ ocorrido em 1988 pode ser considerado como um marco na história da Fonoaudiologia, uma vez que promoveu a discussão sobre a atuação da área no campo da saúde pública e coletiva, possibilitando que as experiências fossem refletidas pela comunidade científica, acadêmica e profissional de todo o país. Foram proferidas 21 conferências, diversos temas livres, painéis e experiências de profissionais de todo o Brasil foram apresentados e documentados. Nota-se no entanto, pelo teor dos títulos e até mesmo dos conteúdos apresentados, que a Fonoaudiologia apenas iniciava sua experiência e inserção no campo da saúde pública e coletiva, apresentando temas sempre voltados para uma visão preventiva que

\footnotetext{
${ }^{7}$ O documento elaborado foi encaminhado ao Ministério da Saúde para a Secretaria Nacional de Programas Especiais de Saúde.

${ }^{8}$ O Encontro Nacional de Fonoaudiologia Social e Preventiva em 1988 foi realizado pelo Conselho Regional de Fonoaudiologia - $2^{\mathrm{a}}$ Região - SP, MT e MS.
} 
muitas vezes ainda refletia sua maior atuação na saúde individual e com uma abordagem mais clinica. Apesar disso, podemos apontar a importancia que o Encontro Nacional de Fonoaudiologia Social e Preventiva teve no discurso do Fonoaudiólogo que passa a ter a prevenção como mais uma de suas palavras de ordem, apesar de nem sempre saber como desenvolver tais açōes. Serão descritos a seguir resumos das conferências pronunciadas no Encontro Nacional de Fonoaudiologia Social e Preventiva:

Hilgert (1988) apresentou o plano da Organização Mundial de Saúde que preconiza "Saúde para Todos no Ano 2000", apontando para o fato de que o modelo que prevê a unificação e descentralização dos serviços de saúde é o que melhor se enquadra para alcançar tal objetivo. O autor apontou os Sistemas Locais de Saúde como uma forma de suprir as deficiências do sistema de saúde, mas também antecipou as dificuldades voltadas aos recursos necessários. Especificamente quanto à Fonoaudiologia, sugeriu que fossem fixadas algumas prioridades, além de se traçar um plano claro e objetivo com relação a um projeto de âmbito federal. Forneceu ainda uma lista de açōes que já podem justificar um amplo projeto.

Bedin (1988) apresentou aos participantes do Encontro Nacional de Fonoaudiologia Social e Preventiva uma introdução ao campo da Saúde Coletiva, da Epidemiologia e do Sistema de Atenção à Saúde. Neste último, ressaltou os principios do Sistema Único de Saúde que prevê uma regionalização e hierarquização das unidades prestadoras de serviço, além da universalização do acesso às mesmas. Destacou a diferenciação dos diferentes niveis de atenção à saúde e a importância do Nivel de Atenção Primária à Saúde, onde seria possível solucionar $70 \%$ dos problemas de saúde de uma comunidade. Considerou o autor que é no nível de Atenção Primária à Saúde que a Fonoaudiologia deveria ter sua maior inserção. Acredita, portanto, que a Fonoaudiologia deveria mostrar qual è o seu papel, e qual a eficácia de suas açōes. Considera o autor que "procurar adaptá-las as unidades básicas de saúde é uma meta que todos nós 
comprometidos com a saúde da população e responsáveis pela consolidação de um "novo" sistema temos que adotar".

Andrade (1988) apresentou os conceitos de saúde e de saúde pública, lembrando que esta última tem como objetivo a promoção, proteção e recuperação da saúde de uma determinada comunidade, por meio de uma assistência integral à saúde. Ou seja, com medidas preventivas e curativas. Apontou a autora que a Fonoaudiologia deveria estar realizando uma reflexão que permitisse a institucionalização e sistematização da prevenção aos distúrbios da comunicação. Considerou que a prevenção em Fonoaudiologia "consiste na eliminação dos fatores que interferem na aquisição e desenvolvimento dos padrões da articulação, fluência, linguagem oral, escrita, voz e audição, na suposição de que essas alterações se desenvolvam em estágios progressivos de severidade." Em seguida a autora descreveu os niveis de prevenção primária (promoção de saúde, proteção especifica), prevenção secundária (diagnóstico e tratamento precoces e limitação da invalidez) e prevenção terciária (reabilitação), conceitos extraídos de Leavell e Clark (1976). A autora comentou em seu artigo a formação do Fonoaudiólogo e também fez referência ao pequeno número de profissionais disponíveis na rede pública de saúde.

Costa (1988) apresentou seu discurso sobre Genética e Prevenção das Alterações Genéticas apresentando as síndromes genéticas e principalmente as alteraçōes de linguagem decorrentes dessas. Apontou então para o aconselhamento como forma de prevenção dos distúrbios genéticos que determinam um comprometimento de linguagem. Colocou ainda que em alguns casos pode haver a complementação por meio de um diagnóstico pré-natal.

Segre e Chapchap (1988) apresentaram em Neonatologia e Prevenção das Alterações Fonoaudiológicas a importância do diagnóstico o mais cedo possivel das deficiências auditivas. Colocaram a necessidade de uma intervenção terapêutica $o$ quanto antes para que possa ocorrer um benefício desse 
diagnóstico precoce. Dessa forma, apresentaram a experiência obtida no Hospital Israelita Albert Einstein com a triagem auditiva neonatal.

Witter (1988), ao discurşar sobre as Implicações Sociais da Linguagem, primeiramente retomou o próprio significado de linguagem e suas diferentes formas de apresentação, para em seguida apresentar as implicaçōes sociais da linguagem. Do seu ponto de vista, tais implicaçōes poderiam ser enfocadas do prisma da pessoa, da sociedade como um todo e da interação da pessoa com os vários segmentos da sociedade. Colocou a autora que no nivel da sociedade a "linguagem aparece como responsável pela própria evolução social, pela criação, desenvolvimento e preservação da cultura." Continuou suas reflexões afirmando que uma das implicações da linguagem é a viabilização do estabelecimento e manutenção de uma estrutura de poder, que acarreta na diminuição do desenvolvimento pessoal de muitos, chegando até a dificultar o evoluir harmonioso da própria sociedade. Após várias reflexões, finalizou apontando tópicos que deveriam ser enfocados tanto na prevenção de distúrbios de linguagem, como quando se tem um enfoque social da linguagem. Ambos levariam a uma reflexão da prática profissional quando as implicações sociais da linguagem fossem enfocadas.

Marcondes (1988) apresentou em Fatores Ambientais do Crescimento a importância dos fatores ambientais nesse processo. Considerou em seu discurso tanto os fatores genéticos, como os de condições de vida e bio-psico-sociais.

Costa Filho (1988), ao relatar os Aspectos Atuais da Audiologia Preventiva, apresentou as pesquisas que vinham sendo desenvolvidas naquele momento na Pontifícia Universidade Católica de São Paulo, na área de Audiologia, tanto na graduação como no pós-graduação. Relatou os temas que envolviam desde a conscientização da importância da audição e da deficiência auditiva, identificação dessa segunda precocemente, a privação sensorial devido a diferentes causas, o ruido e suas implicações em diversas situaçōes com crianças e trabalhadores, além da reabilitação do indivíduo idoso. 
Lins (1988) discutiu a Fonoaudiologia na Saúde Materno-Infantil, lembrando que era um programa que vinha se desenvolvendo anteriormente a 1985, e centrava suas ações na gestante, no pré-natal, no parto e puerpério. No que se refere à criança, o programa era centrado no recém-nascido (até 28 dias) e no lactente (até 2 anos de idade). Considerou, portanto, a necessidade dos programas de assistência integral à saúde da mulher e da criança para que todas as fases desses indivíduos pudessem ser acompanhadas. A autora analisou que a assistência fonoaudiológica prestada ao pré-escolar e escolar, com ênfase no diagnóstico e tratamento das alterações de linguagem, era precária na rede de saúde do Estado. Havia na época uma escassez de serviços implantados, um pequeno número de profissionais e ausência de um sistema de referência e contra-referência. Concluiu então, que tal situação se devia à politica de saúde vigente na época, mas não esquecendo que ainda era necessário que também o Fonoaudiólogo conquistasse seu espaço para uma maior inserção inclusive em instâncias deliberativas. Apontou para a necessidade de uma organização, coesão e coerência interna enquanto classe profissional, assim como uma "clareza do nosso papel na solução dos problemas de saúde e educação da população."

Bitar (1988) discorreu sobre o papel do Fonoaudiólogo dentro de unidades escolares em seu tema intitulado Fonoaudiologia na Saúde do Escolar. Acreditava a autora que a prática clínica não deveria ser o enfoque no âmbito escolar. Colocou então, que "o fonoaudiólogo deve favorecer a promoção da saúde do escolar e sua proteção especifica, utilizando para tanto os procedimentos que forem compativeis com a realidade da escola."

Andrade e Schochat (1988) no tema Perfil Audiométrico de Trabalhadores de Indústrias Ruidosas apresentaram um pequeno histórico sobre o ruido e a perda auditiva induzida por ruido, além dos resultados de uma pesquisa com trabalhadores de diferentes setores da indústria. 
Guedes (1988) discursou sobre a Atenção Preventiva em Distúrbio Articulatório. Apresentou toda conceituação voltada para o Distúrbio Articulatório e os aspectos envolvidos na prevenção desse distúrbio. Sugeriu assim que a criança em fase de desenvolvimento de linguagem e fala fosse bastante estimulada, não esquecendo que os sistemas digestivos e respiratórios devem ter pleno funcionamento já que participam da articulação. Acrescentou ainda que tanto os pais como aqueles profissionais que lidam com crianças em creches e escolas deveriam estar orientados quanto aos aspectos necessários para a articulação. Acreditava a autora que triagens pudessem direcionar a orientação de uma forma mais objetiva. Finalizou argumentando que "de forma clínica ou preventiva, o profissional deve estar muito mais preocupado com quem manifesta, do que com o que é manifestado."

Proença (1988) também discorreu sobre a articulação, intitulando seu trabalho de Prevenção da Articulação: Uma abordagem clínica. Novamente, os aspectos referentes às necessidades para a articulação foram colocados, ressaltando os órgão vitais, os órgãos sensoriais e os órgãos fono-articulatórios. Descreveu então sua experiência com recém-nascidos, nascidos pré-termo, sindrômicos ou anoxiados, cujo auxilio fonoaudiológico poderia propiciar uma prevenção de futuros problemas de articulação. Não pretendeu esgotar o assunto, e sim ampliar a sua discussão.

Telles (1988) apresentou algumas considerações no tema Ações Preventivas na Voz. Iniciou colocando as manifestaçōes faladas como o tema a ser considerado, até chegar aos aspectos mais especificamente ligados à produção da voz. A comunicação foi o ponto central que sempre norteou sua discussão.

Friedman (1988), ao falar sobre as Ações Preventivas na Fluência, iniciou sua argumentação desenvolvendo uma análise sobre "o par fluência-disfluência e procurando entender também os limites entre o que as pessoas em geral consideram normal e anormal na questão." Discorreu então sobre as emoções e 
sobre a "ideologia do bem falar", que merecem ser desmistificadas. Sugeriu que as ações preventivas da fluência-disfluência podiam se iniciar na própria categoria profissional, na medida em que os próprios Fonoaudiólogos "trabalham sistematicamente sobre a inçapacidade da criança num contexto de constante exigência do bem falar". Sugeriu ainda açōes junto a professores, médicos e pais, esclarecendo-os sobre o desenvolvimento da fala. Sua última sugestão se referia à divulgação na mídia, por meio de rádio, jornais e programas de TV.

Chiari (1988), em Ações Preventivas na Linguagem colocou que falar sobre prevenção em linguagem constitui uma tarefa dificil. Desta forma optou a autora por discorrer em um primeiro momento sobre as conceituações de comunicação, linguagem, língua e fala. Em seguida apresentou as caracteristicas do desenvolvimento normal da linguagem, colocando-o como um "processo complexo, que depende de pressupostos biológicos, determinados geneticamente e fisiológicos de aprendizagem, decorrentes da interação do indivíduo com o meio." Apresentou em seguida a etapa da comunicação no nível pré-lingüístico ( $1^{\circ}$ ano de vida), o $1^{\circ}$ nivel lingüistico ( 1 a 5 anos) e o $2^{\circ}$ nível lingüistico (5-12 anos). Finalizou a autora colocando que a linguagem, ao permear toda a nossa ação no mundo, "possibilita-nos a transmissão de nossos valores, de nossa cultura, o nosso relacionamento interpessoaf".

Braga (1988) discursou sobre as Ações Preventivas em Leitura e Escrita, avaliando que a análise dessa questão pode ser realizada a partir de dois enfoques básicos. Um primeiro estaria privilegiando os aspectos individuais de desempenho, sendo portanto predominantemente clínico. 0 segundo caracteriza-se por "um enfoque educacional, privilegiando comparações de desempenho a partir de niveis de eficiência, determinados por um grupo de leitores." A partir dessas questões e de sua experiência, atuando tanto na linguagem oral como nas dificuldades com a escrita a autora envolve pais e diretores no trabalho a ser desenvolvido. Concluiu que, a partir da análise de intervençōes realizadas tanto quanto ao diagnóstico como em programas de orientação, poderão ser conduzidas "reformulações e elaborações de programas 
que traduzam condutas preventivas adequadas na área da aquisição $e$ desenvolvimento do sistema escrito."

Bevilacqua, Lewis e. Morata (1988) discorreram sobre as Ações Preventivas na Audição. Iniciaram seu relato colocando a importância da audição $e$ as conseqüencias do crescimento urbano desordenado para a audição no homem. Conceituaram ainda os Programas de Conservação Auditiva como "procedimentos organizados a fim de preservar a audição normal (ou já alterada) das pessoas, sua saúde e seu bem-estar". Como as características desses programas variam de acordo com a população a que se destinam, descreveram os principais objetivos de programas de conservação auditiva em crianças entre 0 e 2 anos de idade, em escolares e em trabalhadores. Concluiram que, apesar de estarem em estágio inicial "essas experiências têm demonstrado a sua relevância no sentido de promover senviços, campo para formação de profissionais numa área pouco explorada, acesso a fontes de pesquisa e discussões em grupos da população na busca de soluções para seus problemas especificos."

Leirião (1988) apresentou A Fonoaudiologia no HPLLP durante o Encontro Nacional de Fonoaudiologia Social e Preventiva. Descreveu assim o setor de Fonoaudiologia do Hospital de Pesquisa e Reabilitação de Lesões Lábio-Palatais de Bauru, Estado de São Paulo, e os principais distúrbios que acomentem a comunicação oral dos fissurados lábio-palatais. Em seguida descreveu todo o trabalho, tanto fonoaudiológico como de outros profissionais da saúde do Hospital, que tem como objetivo a reabilitação do fissurado.

Jacob $F^{\circ}(1988)$ apresentou o trabalho multiprofissional desenvolvido pelo Grupo de Assistência Multidisciplinar ao Idoso Ambulatorial - Gamia e mais especificamente da atuação médica, fisioterápica, da terapia ocupacional e da fonoaudiologia. "A ação do fonoaudiólogo visa o incentivo à busca de diferentes oportunidades de comunicação, não só intermitente, mas também no nível da própria comunidade, à busca de seu papel ativo junto a diferentes segmentos, 
explorando as diferentes possibilidades de utilização da linguagem. Mostra-se aí o espaço para ações de prevenção do isolamento e da depressão."

A conferência e artigo apresentados por Cappelletti (1988) tinham como título Repensando a Fonoaudiologia. A autora colocou sua trajetória como docente no Curso de Fonoaudiologia, o que a levou a diversos estudos, pesquisas e reflexões sobre o lugar da Fonoaudiologia, como o Fonoaudiólogo utiliza toda a sua formação na prática profissional, até chegar a avaliar os diversos curriculos de diferentes universidades em São Paulo. O repensar a Fonoaudiologia fez com que a autora colocasse: "A preocupação com o falar, com o escutar, com o discurso compreensivo, desloca o foco da Fonoaudiologia para além dos quadros clínicos restritos às "patologias", para abranger a linguagem como estado "ex-pressado" da fala, do ensino normativo da língua, para abranger o discurso compreensivo, a expressividade da mensagem, a expressão do discurso." Continuou ainda a autora refletindo sobre o fazer do Fonoaudiólogo, por meio das colocações de como os usuários de serviços de Fonoaudiologia vêem este profissional. Finalizou colocando a importância das universidades na reflexão sobre a profissão, além de discorrer sobre a inserção do Fonoaudiólogo no sistema de saúde.

Os temas livres, painéis e experiências pessoais colocados no Encontro Nacional de Fonoaudiologia Social e Preventiva mostraram diversas experiências e projetos iniciais ou pilotos em favelas, creches, centros de saúde, escolas e SESI, entre outros.

Vale ressaltar o tema livre apresentado por Paoletti, Basilio, Silva, Cardoso e Mallet (1988) que relata Projeto Piloto em Saúde Pública: Relato sobre a Implantação e Desenvolvimento nas Unidades Básicas de Saúde do SUDS R-12 São Paulo - SP. O projeto abrangia os municipios de Embu, Cotia, Vargem Grande Paulista, Taboão da Serra e Itapecerica da Serra, onde foram implantados serviços de Fonoaudiologia na rede básica de saúde para "o desenvolvimento de ações voltadas à prevenção de distúrbios e promoção da 
saúde no que se refere a comunicação humana." Segundo as autoras, evidenciou-se a inserção do Serviço de Fonoaudiologia, dando-se início a definição do papel do Fonoaudiólogo no nível de Atenção Primária à Saúde.

As produçōes encontradas nos anais do Encontro de Fonoaudiologia Social e Preventiva, realizado em 1988, mostraram que os autores apresentaram a prática fonoaudiológica mais voltada aos aspectos preventivos e clínicos voltados à identificação, diagnóstico e reabilitação dos distúrbios da audição e linguagem. A prática fonoaudiológica especificamente voltada ao nível de Atenção Primária à Saúde, sua especificidade e reflexões voltadas a um novo fazer profissional foram raramente discutidos. Encontrou-se em um número reduzido de artigos questionamentos sobre a prática fonoaudiológica nos serviços de saúde e mesmo sobre os pressupostos teóricos que a embasam. Tal fato aparece em decorrência da pequena inserção da profissão nos serviços públicos de saúde na época e a recente modificação na estrutura curricular dos Cursos de Fonoaudiologia. No entanto, o Encontro Nacional de Fonoaudiologia Social e Preventiva foi um marco histórico sem precedentes para que os profissionais da área iniciassem uma série de produções e eventos que discutissem a inserção, a prática e a formação do Fonoaudiólogo na área da saúde.

Em artigo que discute o campo de atuação do Fonoaudiólogo, Lins e Andrade (1990) descreveram diferentes pesquisas que mostram com que frequêencia os distúrbios da comunicação vêm sendo relatados. No entanto apontaram para o fato de que no Brasil não dispomos de estatísticas precisas sobre 0 assunto, apesar de acreditarem que aqui existam maiores percentuais devido às precárias condições de vida e de saúde da nossa população. Respaldaram tal observação no fato de encontrarem dados que mostram uma demanda reprimida em todos os serviços públicos que contam com assistência fonoaudiológica. Colocaram ainda as autoras, que tal situação se manterá indefinidamente se os processos patológicos alcançarem etapas avançadas. Apontaram dessa forma para a necessidade de se prestar assistência 
fonoaudiológica primária e secundária, pois a maior parte dos distúrbios da comunicação é passivel de intervenção em estágios de menor gravidade.

Andrade (1990a) discutiu a situação do Fonoaudiólogo no sistema de saúde. Colocou a autora que parece existir um descaso por parte dos órgãos competentes, com os portadores de patologias da comunicação. Discutiu a autora $o$ fato de que os indivíduos que necessitam de atendimento fonoaudiológico, sobrevivem sem o mesmo, sem onerar assim o sistema de saúde. Colocou ainda que nos estados de São Paulo, Mato Grosso e Mato Grosso do Sul, somente $10 \%$ dos órgãos públicos mantêm fonoaudiólogos em seus quadros profissionais e quase exclusivamente no nivel de atenção terciária à saúde. Concluiu assim que há uma impossibilidade destes profissionais suprirem a demanda, tornando-se portanto necessária a contratação urgente e em número significativo, de Fonoaudiólogos que atuem no sistema de saúde e educação.

Durante $01^{\circ}$ Congresso Brasileiro de Epidemiologia realizado em Campinas - SP, Andrade, Wertzner e Lopes (1990) apresentaram os resultados de um estudo epidemiológico que visou levantar os distúrbios da comunicação na população infantil usuária de um Centro de Saúde no município de São Paulo. Os resultados foram analisados pelas autoras que concluiram haver uma necessidade de se racionalizar a ação estatal, gerando assim um planejamento e execução de medidas que possibilitariam um atendimento fonoaudiológico nos três niveis de atenção.

Andrade, Lopes e Wertzner (1991) criticaram o estado de saúde de grande parte da população brasileira, apontando para aqueles que necessitam de atendimento fonoaudiológico e que acabam tendo comprometida a sua capacidade de exprimir idéias e transformar o mundo pelas palavras. Apontaram assim para a necessidade de uma maior inserção da Fonoaudiologia no sistema de atenção primária à saúde, "com adequado sistema de referência e contra- 
referência, como forma de abrir as portas para que a população venha a alcançar a saúde plena".

Ramos (1991) em artigo que pretendia contribuir para a reflexão sobre a construção da identidade do Fonoaudiólogo, acabou por realizar uma análise sobre a prática fonoaudiológica e os aspectos ideológicos que fundamentam esta prática. Acreditava a autora que o trabalho da Fonoaudiologia na Saúde Pública deveria estar embasado em principios mais voltados à promoção da saúde e a tomada de consciência da população de sua condição de vida, de saúde e de seus aspectos lingüisticos.

Lopes (1991), em pesquisa para dissertação de mestrado tinha como objetivo caracterizar o perfil profissional do Fonoaudiólogo que trabalha em Centros de Saúde em São Paulo, caracterizar o paciente atendido em Serviços de Fonoaudiologia nesses Centros de Saúde e caracterizar os próprios Serviços de Fonoaudiologia no que se refere a formas e critérios de atendimento $e$ documentação existente. Após a coleta e análise dos dados, a pesquisadora chegou a várias conclusões que merecem ser aqui expostas. Uma delas se refere à falta de documentação existente para os casos atendidos em Fonoaudiologia. Tal fato merece preocupação, uma vez que todo e qualquer atendimento deve ser registrado nos prontuários dos pacientes. Os dados referentes à caracterização dos pacientes e patologias atendidas não serão aqui descritos, uma vez que não fazem parte do objetivo central deste trabalho. Outra conclusão interessante está relacionada ao desconhecimento que os usuários têm sobre a Fonoaudiologia. Analisou a pesquisadora que a falta de profissionais na rede pública acarreta um desconhecimento sobre a especialidade, que se justifica também pela recente inserção do Fonoaudiólogo nos serviços públicos de saúde. Outro aspecto importante referiu-se ao abandono do tratamento fonoaudiológico antes do seu término. A autora comentou que o Fonoaudiólogo deveria refletir sobre a forma como sedimenta e justifica o seu trabalho junto aos usuários, ou até como se dá a efetivação desse trabalho. Outro aspecto importante a ser colocado está ligado à conclusão de 
que somente as manifestações primárias de linguagem são possiveis de serem atendidas nos Centros de Saúde da Rede Básica. Concluiu assim a autora que o Fonoaudiólogo deve estabelecer um trabalho organizado dentro dos Níveis de Atenção à Saúde, ou seja, Atenção Primária, Atenção Secundária e Atenção Terciária, estabelecendo o que compete realizar em cada nivel. Salientou ainda que, no que se refere à regionalização dos atendimentos, há a necessidade de implantação de Serviços de Fonoaudiologia em todas as regiōes, com sistemas adequados de referência e contra-referência para uma maior efetivação, eficácia e ampliação dos serviços prestados. Sugeriu a pesquisadora que o Fonoaudiólogo atuante nos Centros de Saúde focalize o seu trabalho nas ações preventivas.

Andrade (1991) desenvolveu sua pesquisa para dissertação de mestrado com o objetivo de conhecer o conceito de saúde e a inter-relação entre a habilidade e efetividade da comunicação e a visão de saúde holística. Para tanto, além de toda uma revisão bibliográfica do assunto, a autora realizou entrevistas com diferentes profissionais da saúde, com fonoaudiólogos especificamente e com pacientes e pais de pacientes usuários de serviços públicos de Fonoaudiologia. Concluiu após análise que "a saúde é vista sob uma perspectiva reducionista e que uma abordagem holistica da saúde não pode desconsiderar a capacidade comunicativa do homem."

Freire (1992) colocou sua experiência na implantação de um serviço de Fonoaudiologia na rede pública de saúde, também com o objetivo de discutir o entendimento do trabalho ou funçōes do fonoaudiólogo no contexto especifico de Unidades Básicas de Saúde. Colocou ainda a Fonoaudiologia como uma das profissões que não está tradicionalmente incorporada por essas unidades. A autora colocou que tal fato contribuiu para que não fossem oferecidas situações de ensino para alunos em formação, havendo assim um desconhecimento do contexto histórico geral da saúde pública e da clientela a quem ela é oferecida. Afirma ainda que a formação do Fonoaudiólogo tem sido dirigida a um tipo de atuação clínica autônoma. A experiência de 3 anos em diferentes Unidades 
Básicas de Saúde possibilitou que a autora descrevesse o desenvolvimento da atuação fonoaudiológica nessas unidades, colocando inclusive o número de casos encaminhados, por quem e quais os tipos de distúrbios da comunicação encontrados.

Andrade e Lopes (1993) desenvolveram uma pesquisa com o objetivo de levantar o conhecimento que Fonoaudiólogos atuantes no serviço público e privado tem sobre a atividade preventiva nas patologias da comunicação humana. Realizaram inclusive uma análise comparativa entre os dois grupos de profissionais estudados. Após a análise das respostas desses profissionais, as autoras concluíram que existia uma necessidade premente de revisão do ponto de vista atual sobre a atuação fonoaudiológica na saúde, além de constatarem que os recursos humanos não acompanharam o processo de desenvolvimento dos conhecimentos científicos na área. Entre as conclusões mais relevantes, apontaram para o fato de ser necessária a introdução $e$ integração da Fonoaudiologia nos programas de saúde já existentes.

Camargo (1993) realizou estudo com objetivo de conhecer e compreender as concepções que respaldam o trabalho de fonoaudiologia nos serviços públicos de saúde em Bauru, Estado de São Paulo, sob duas perspectivas: a de quem presta e de quem recebe o serviço. A autora escolheu as representações sociais como metodologia a ser utilizada, respaldando-se nas contribuições destas para a pesquisa na área da saúde. Após o estudo aprofundado de uma entrevista com um fonoaudiólogo e uma entrevista com uma mãe, analisou e concluiu que várias questões deveriam ser repensadas entre os fonoaudiólogos, entre as quais podem citar-se: acabar com a dicotomia entre o prevenir e o curar; assumir um trabalho mais coletivo; romper com a patologização; não considerar apenas o aspecto técnico e somar nossos conhecimentos com o de outros atores sociais, com o objetivo de identificar os problemas e buscar as soluções.

Andrade (1994) discorreu sobre a comunicação humana e principalmente sobre a saúde e a doença fonoaudiológica. Comentou a autora que as doenças 
da comunicação humana "não se caracterizam por alterações laboratoriais, não saram pela ingestão de drogas, não provocam dor, nem levam o indivíduo à morte. O doente fonoaudiológico sofre de uma manifestação patológica que altera sua saúde fundamentâlmente pelo sofrimento; pela perda ou insucesso da capacidade fundamental e estrita de sua espécie, que é a de processar a produção e expressão de suas idéias e do poder de pela palavra criar e transformar o mundo." A autora revelou também que durante pesquisa de dissertação de mestrado, pôde observar que os indivíduos entrevistados não identificavam as patologias fonoaudiológicas como "doenças". Colocou ainda a definição de doenças fonoaudiológicas e suas causas. Finalizando, a autora discursou sobre as doenças fonoaudiológicas do escolar e a atuação fonoaudiológica proposta em caráter individual clínico ou preventivo por meio de programas. Coloca ainda que os "programas de prevenção fonoaudiológica em escolas pretendem minimizar a influência dos fatores que interferem na aquisição e desenvolvimento das doenças da comunicação, pela detecção e tratamento precoce das alterações e finalmente pela redução das seqüelas e o restabelecimento efetivo da funcionalidade."

Servilha, Jesus, Soares, Santos, Rodrigues e Santana (1994) organizaram uma coletânea de artigos que mostram o histórico da implantação dos serviços públicos de saúde nos municípios de Ibiúna, Itu, Porto Feliz, Salto, Sorocaba e Votorantim. Além disso, as autoras realizam uma reflexão sobre a Fonoaudiologia nos serviços públicos de saúde do Sistema Único de Saúde, mais especificamente na região 59 no Estado de São Paulo. Apontaram para o fato de que nos locais onde a saúde está municipalizada há não só a implantação, mas também a ampliação dos serviços de Fonoaudiologia. Acreditavam que essa ampliação não tem se dado graças a uma reivindicação da população, já que, provavelmente, a atuação do Fonoaudiólogo como profissional da saúde ainda é desconhecida da maioria dos usuários dos serviços de saúde. Apontaram para o fato dos serviços terem se iniciado enfocando mais a área de reabilitação,de acordo com uma priorização que culturalmente acontece no sistema de saúde brasileiro, contrariando os pressupostos do Sistema Único de Saúde, que prioriza 
a Atenção Primária à Saúde. Descreveram as áreas de atuação dos Fonoaudiólogos como a clínica, a escola, a unidade básica de saúde, a audiologia, a creche, o programa de saúde do trabalhador e o programa de saúde vocal.

Em 1994, o Centro de Estudos Fonoaudiológicos da Escola Paulista de Medicina, organizou o VI Seminário Interdisciplinar - CEFA, cujo tema foi: Fonoaudiologia e Saúde Pública. As conferências mostraram os modelos de atuação fonoaudiológica nas Unidades Básicas de Saúde, o papel das universidades na formação teórico-prática do Fonoaudiólogo e ações preventivas em Fonoaudiologia. Diversos temas livres, tanto de origem acadêmica como de experiências profissionais, também foram mostrados. A seguir serão resumidas as conferências apresentadas no seminário:

Ortiz e Bertachini (1994) apresentaram um Modelo de Atuação Fonoaudiológica em Unidades Básicas de Saúde. Para tanto apresentaram a tecnologia utilizada para sua atuação em duas unidades de saúde distintas, onde um projeto de docência assistencial vinha sendo desenvolvido. Foram realizadas reuniōes nessas unidades com o objetivo de conhecer os programas desenvolvidos por elas e nos quais a Fonoaudiologia poderia atuar. Apresentaram entāo os programas que tinham a participação da Fonoaudiologia: Na UBS: Vigilância do Crescimento e Desenvolvimento - Puericultura; Acompanhamento de Crianças Desnutridas. Desenvolviam ainda: Exames Fonoaudiológicos, Orientação e Estimulação da Audição e Linguagem em grupos; Atuação em creches e escolas. No Centro de Saúde: Ações diagnósticas e Preventivas; Ações informativas através de palestras tanto aos usuários como para profissionais do Centro de Saúde; Ações Fonoaudiológicas em Escolas de $1^{\circ} \mathrm{e} 2^{\circ} \mathrm{grau}$.

Rizzi (1994) apresentou os Programas de Educação para a Promoção da Saúde da Comunicação Humana. Afirmou a autora que os "programas de atuação dos fonoaudiólogos na Prefeitura Municipal de São Paulo são 
semelhantes, apesar das diferenças das regiōes de São Paulo." Esses dados foram obtidos no I Encontro de Fonoaudiologia da Prefeitura Municipal de São Paulo e revelaram a atuação do Fonoaudiólogo no municipio: Em Unidades Básicas de Saúde desenvolvem: ações clinicas (triagem fonoaudiológica, avaliação, orientação e terapia); açōes coletivas: trabalho com a comunidade (creches e escolas); em centros de convivência: entrevistas, orientação, encaminhamentos e oficinas com trabalho multiprofissional; em ambulatório de especialidades: avaliação multiprofissional em ações clínicas e coletivas; em hospitais: atuando em berçários, enfermarias, unidades de terapia intensiva, em ambulatório, realizando grupos educativos multiprofissionais e em audiologia clínica; em centro de referência de saúde do trabalhador: no atendimento aos trabalhadores, nas ações de vigilância e grupos educacionais; em centro de referência de saúde da criança: com grupos educativos multiprofissionais, com distúrbios emocionais em crianças de 0 a 12 anos de idade; em centro de referência infantil: com grupos educativos multiprofissionais e distürbios neurológicos; em hospital-dia: em equipe multidisciplinar com crianças com comprometimento emocional grave.

Soares (1994), representando as comissōes de saúde e educação do Conselho Regional de Fonoaudiologia $2^{a}$ Região, levantou algumas questões tanto quanto à formação como à prática do Fonoaudiólogo em Saúde Pública, com o objetivo de suscitar reflexōes sobre programas, modelos, ações e política de saúde. Propôs assim questões tanto de formação, como de pesquisa epidemiológica que subsidiem a prática fonoaudiológica. Comentou ainda questōes relativas a própria implantação do Sistema Único de Saúde.

Bernardi (1994) comentou a Experiência do Programa de Saúde dos Trabalhadores da Zona Norte, colocando; uma breve exposição sobre a Reforma Sanitária no país, sobre os programa de saúde do trabalhador e seus objetivos e mais especificamente sobre o setor de audiologia desse programa e sua atividade em grupo com os trabalhadores. 
Lewis (1994) discorreu sobre A Universidade e os Serviços de Saúde: Currículo e Prática na Formação do Fonoaudiólogo. Nesse trabalho apresentou disciplinas obrigatórias e eletivas apresentadas desde 1986 aos alunos do Curso de Fonoaudiologia da PUC-ȘP e que têm como objetivo "o estudo e a pesquisa no campo da Saúde Pública, e uma prática nos serviços de saúde através de estágios supervisionados". Mostrou que os alunos podem vivenciar experiências tanto no nivel de Atenção Primária, como em Ambulatórios de Especialidades e Centros de Referência.

Cavalheiro (1994) apresentou A Universidade e o Serviço de Saúde: Currículo e Prática na Formação do Fonoaudiólogo da PUCCAMP. Colocou um breve histórico sobre o curso de Fonoaudiologia da PUCCAMP, que em 1994 estaria implantando um novo currículo, com o qual pretendiam oferecer aos alunos uma nova proposta de pesquisa e serviços de extensão nos três níveis de atenção do sistema de saúde. Novas disciplinas como "Saúde e Sociedade" e "Saúde Pública e Preventiva" servem de pré-requisito para disciplinas "Fonoaudiologia Preventiva I, II e III". Estágios que eram desenvolvidos prioritariamente com caráter clínico terapêutico seriam levados também a Unidades Básicas de Saúde, Hospitais, Instituições Educacionais e outros.

Befi (1994) apresentou no seminário A Formação do Fonoaudiólogo: Inserção no Sistema de Saúde. Refletiu a autora sobre o Fonoaudiólogo, profissional da saúde, que fora de seu consultório privado deveria privilegiar suas ações ao coletivo em detrimento do individual. Lembrou ainda que o sistema de saúde não tem identidade com esse profissional, que deveria estar realizando uma proposta coerente com o local no qual está se inserindo. Finalizou com a seguinte colocação: "Considerando que a Universidade forma, habilita, confere competência, que é da Universidade, da Escola, que o fonoaudiólogo sai para o mercado de trabalho e que é dessas instituições que deve sair o profissional competente, capaz de inserir-se no sistema de saúde e prestar um serviço de qualidade, é que acreditamos que hoje, além da formação técnico-científica de excelente nivel que devemos fornecer a nossos alunos, devemos garantir 
também sua formação técnico-administrativa, com o mesmo nível de competência."

Costa (1994), representando a Universidade Camilo Castelo Branco colocou a preocupação dessa universidade com a formação de seu aluno em Saúde Pública. Nesse sentido, são oferecidas as disciplinas "Fonoaudiologia Social e Preventiva" em que durante dois anos, os alunos desenvolvem atividades práticas visando as ações coletivas em creches, escolas, asilos, indústrias, maternidades, escolas especiais, teatro e rádio. Em todas as disciplinas a "promoção da saúde coletiva tem sido destaque, procurando-se despertar no aluno a questão preventiva dos Distúrbios da Comunicação Humana e o papel indispensável do fonoaudiólogo nesta área."

Schochat (1994) apresentou A Saúde Auditiva do Trabalhador, em que mostrou o ruido e sua relação com a perda auditiva induzida pelo ruído. Essas colocações serviram para introduzir o Programa de Saúde do Trabalhador do Centro de Saúde Escola Samuel B. Pessoa da USP.

Wertzner (1994) apresentou a Saúde da Comunicação Oral no Pré-Escolar e Escolar. Introduziu o tema colocando questões breves sobre a comunicação humana e sobre o pré-escolar e escolar, para depois discorrer sobre as alterações de maior ocorrência no pré-escolar e escolar. Finalizou revelando que "A caracterização da aquisição e desenvolvimento da linguagem da população infantil possibilita a adequação dos diagnósticos e tratamentos precoce da comunicação oral, assim como fornece os dados necessários para a elaboração de programas de promoção e proteção especifica da comunicação oral."

Guedes (1994), ao discursar sobre a Fonoaudiologia Educacional: Ações na Escola, colocou que o Fonoaudiólogo deve ter o conhecimento da nossa própria lingua e das influências socioculturais para que possa propor ações de prevenção primária e secundária. Colocou ainda que a língua é influenciada pelo ambiente sociocultural, fazendo com que alguns individuos manifestem sua fala 
de forma "diferente". Essas diferenças podem ser observadas na escola sendo que nem sempre os educadores conseguem lidar com essas questões. Colocou então a autora que "a atuação preventiva que deve ser realizada pelo fonoaudiólogo tem o intuitorde minimizar os distúrbios da comunicação dos individuos que se utilizam da linguagem com caracteristicas que a tornam "diferente"."

Mendes (1994) realizou pesquisa para dissertação de mestrado, com o objetivo de analisar o acesso do usuário de diferentes Unidades Básicas de Saúde aos respectivos serviços de Fonoaudiologia lá existentes. Esse estudo foi realizado a partir da análise das práticas realizadas pelos profissionais, tendo como embasamento teórico para discussão a caracterização do distrito sanitário e dos setores de Fonoaudiologia. A autora descreveu toda conceituação de Administração Regional de Saúde, Distrito Sanitário, fazendo inclusive um histórico do distrito em questão. Após a análise dos dados coletados, a autora refletiu sobre questōes que levam a três dimensões problemáticas: a do ângulo técnico-institucional (que possibilita a organização do acesso e atendimento dos usuários), a da formação profissional (quanto aos aspectos voltados para a saúde pública) e a da natureza estrutural da Unidade Básica de Saúde (sua dinâmica e relação com as políticas do distrito de saúde). Entre várias reflexões, colocou: "Somente se nos dispusermos a reconstruir nossas práticas é que poderemos colaborar para a construção do novo Sistema de Saúde. Estou falando aqui de acessar propostas e experiências disponiveis na área (no âmbito público e privado) e de criar novas metodologias que possam vitalizar e democratizar os serviços à população. Para isso a Fonoaudiologia necessita rever sua clínica, como também criar outras possibilidades de intervenção no campo preventivo e de promoção de saúde, tendo por guia a realidade concreta da região em que se atue."

Andrade (1994), dando continuidade as suas reflexōes no campo da saúde, desenvolveu tese de doutoramento voltada para a Fonoaudiologia Preventiva. A partir do discurso científico-pedagógico de professores e 
fonoaudiólogos de universidades no município de São Paulo, a autora desenvolveu um modelo de Fonoaudiologia Preventiva e um Vocabulário Técnico-Científico. A autora concluiu que as definições apresentadas pelos entrevistados eram incompletas, de caráter arbitrário, privilegiando atributos isolados e não representando esse campo da Fonoaudiologia como um objeto delimitado. Apontou que, os discursos de Fonoaudiólogos se mostram causais e fragmentados, sustentando uma visão restrita desse campo de conhecimento, o que limita assim sua pesquisa e prática. Além de outras reflexões sobre a formação, conhecimento e prática do fonoaudiólogo no campo da Fonoaudiologia Preventiva, a autora descreveu um modelo, pautado no modelo preventivo de Leavell e Clark (1976) e que será resumido a seguir:

Promocão da Saúde Fonoaudiológica: Atenção aos fatores meta-pessoais (realidade social, econômica, cultural, política, ecológica, etc.) e Atenção aos fatores pessoais (caracteristicas físicas, psicológicas, espirituais, e sociais próximas). Ex.: controle da poluição prevenindo desordens vocais; segurança, saúde e educação que promoverão a saúde em geral e a saúde fonoaudiológica conseqüentemente.

Protecão Especifica à Saúde Fonoaudiológica: Devido ao desconhecimento das histórias naturais da doença, sugere que o controle das doenças seja dado com ênfase aos programas educacionais, fornecendo amplo conhecimento à comunidade sobre patologias da comunicação ou mais especificamente sobre a doença e a saúde fonoaudiológica. Ex.: programas educacionais direcionados a gestantes, a pais, creches, indústrias, entre outros.

Diagnóstico e Tratamento das Ocorrências Fonoaudiológicas: A autora coloca que pouco pode ser sugerido, no que já é feito com propriedade pelo fonoaudiólogo. No entanto ressalta a importância das triagens em massa para um maior conhecimento da incidência e prevalência dos distúrbios da comunicação, além de sua distribuição na população.

Limitacão das Seqüelas e Incapacidades Fonoaudiológicas: Segundo a autora, uma das fases mais dificeis de se especificar. Exemplifica com "os casos que chegam para atendimento fonoaudiológico acompanhado de seqüelas 
emocionais e/ou relacionadas às questōes do aprendizado escolar decorrentes de alterações orais não solucionadas."

Reabilitacão Fonoaudiológica: Intervenções com o objetivo de minorar "o sofrimento produzido por alterações patológicas que determinaram seqüelas comunicativas graves e até irreversiveis."

O Vocabulário Técnico-Científico não pode e não deve ser resumido. Sugerimos-se para os interessados a leitura dos originais da tese de doutoramento de Andrade (1994).

Vieira, Vieira Avila e Pereira (1995) apresentaram uma coletânea de artigos sob o titulo Fonoaudiologia e Saúde Pública, contribuindo assim para a formação do Fonoaudiólogo no campo da Saúde Pública. A seguir serão apresentados os resumos dos artigos voltados especificamente para a prática do Fonoaudiólogo, ainda que a coletânea apresente artigos que discorrem sobre o histórico da Saúde Pública, sobre o sistema de saúde no pais, entre outros.

Andrade (1995) apresentou em seu capitulo as Fases e Niveis de Prevenção em Fonoaudiologia - Ações Coletivas e Individuais. Iniciou o capitulo colocando as definições de saúde, doença e prevenção, para depois discorrer sobre o modelo de Prevenção em Fonoaudiologia fundamentado nos conceitos de prevenção de Leavell \& Clark (1976). Concluiu a autora que "para a efetivação da promoção e proteção da saúde fonoaudiológica, através de esforços preventivos especificos, é fundamental uma mudança ideológica dos nossos profissionais."

Pasetti (1995) apresentou a Atuação Fonoaudiológica na Sua Realidade Sociocultural, discorrendo sobre um serviço novo dentro da Prefeitura Municipal de São Paulo: os Centros de Convivência e Cooperativa (CECCO). Os CECCOs "são espaços de resgate à cidadania e de valorização do potencial que cada individuo possui." O modelo utilizado nos CECCOs pretende garantir um novo modelo de atenção integral à Saúde Mental. O fonoaudiólogo poderá ter como 
objetivo facilitar e estimular a comunicação oral, gestual, escrita etc., por meio de oficinas, fundamentalmente de caráter multiprofissional. Concluiu que a atuação fonoaudiológica dentro dos CECCOs é "essencialmente social e procura resgatar as diversas culturas encontradas nos pontos da cidade de Sáo Paulo, procurando montar os serviços de acordo com as necessidades desses locais."

Ortiz, Bertachini e Pereira (1995) apresentaram novamente a experiência vivenciada em duas Unidades Básicas de Saúde, acrescentando apenas algumas definiçōes voltadas especificamente para o papel das UBSs dentro do sistema de saúde. Além disso, apresentaram o programa de atuação fonoaudiológica "Promoção da Prevenção" que reúne medidas preventivas e tem como objetivo evitar ou minimizar os distúrbios da comunicação. O Programa pode ocorrer de forma individual na avaliação de cada paciente, ou coletiva em grupos de mães e de outros pacientes atendidos pelo Centro de Saúde.

Masson (1995) realizou pesquisa com o objetivo de analisar a construção do conceito de prevenção em Fonoaudiologia. A autora iniciou sua pesquisa com os documentos que datam da década de 20 até os dias atuais e estudou como a Fonoaudiologia incorporou em seu discurso o conceito de Prevenção, a partir de fundamentos da Medicina Preventiva. Para complementar seu trabalho realizou pequena incursão na construção do conceito de Promoção de Saúde, que os profissionais em Fonoaudiologia vêm utilizando. A autora analisou as diferentes práticas tomadas como preventivas e fundamentadas no modelo da História Natural da Doença de Leavell \& Clark, e pautadas portanto na doença, seja do indivíduo, seja no coletivo. Comentou a autora que, mesmo na promoção de saúde, as práticas estavam mais voltadas à doença. Finalizou com a seguinte colocação: "a resposta não estaria nem na prevenção, nem na reabilitação. Nosso papel enquanto profissionais da saúde está em conseguir olhar para a construção do processo de saúde/doença da população como parte de sua condição de sujeito, inserido em uma determinada estrutura social para, aí sim, podermos estabelecer nem uma nem outra; mas quais seriam as atividades de promoção de saúde, prevenção da doença propriamente dita e reabilitação 
necessárias para aquela comunidade, considerando os agravos de saúde incidência e prevalência dos distúrbios da comunicação - que lhes são particulares."

Notamos um crescimento nas produções de fonoaudiólogos voltadas à prática do profissional nos serviços públicos de saúde. A produção científica mostrou-se, inicialmente, através de comunicações em congressos e encontros, e atualmente, já com a produção de dissertaçōes de mestrado e teses de doutorado, além da organização de livros.

Apesar das produções da década de 90 não estarem tão voltadas aos aspectos técnicos da clínica fonoaudiológica, mostrando um aumento na preocupação com a inserção do Fonoaudiólogo no nivel de Atenção Primária à Saúde, os pressupostos que norteiam os discursos ainda são similares àqueles encontrados no final da década de 80. Similares, apesar de mais sofisticados e elaborados quanto à propostas de atuação profissional. O modelo de Leavel \& Clark (1976), apontando para uma abordagem estratificante de ações que visam a prevenção, promoção da saúde e a recuperação da mesma, é o mais evidente na produção encontrada. Apontam-se dificuldades na realização das ações, além da constataçāo de que o Fonoaudiólogo ainda necessita aumentar sua inserção nos serviços públicos de saúde. Esse aumento refere-se tanto ao número de profissionais atualmente contratados para atuarem em unidades de saúde, como também no que se refere ao desenvolvimento de ações.

A produção cientifica referente à prática fonoaudiológica no nivel de Atenção Primária à Saúde será resgatada na análise desse trabalho, apontando aspectos que foram objetivados e ancorados pelos profissionais entrevistados e evidentes em suas representaçōes. 


\section{PROCEDIMENTOS PARA COLETA E ANÁLISE DOS DADOS}

Conforme já foi dito anteriormente, para que o objetivo delimitado para esta pesquisa pudesse ser alcançado, os procedimentos de coleta e análise dos dados foram pautados na Teoria das Representações Sociais.

Para que pudéssemos investigar as representaçōes sociais que norteiam a prática fonoaudiológica nos serviços públicos de saúde no Município de São Paulo, optou-se pela coleta e análise de dados através de dois niveis de produção de sentido. $O$ primeiro deu-se ao nivel da consciência compartilhada, para que se pudesse apreender as representações comuns entre - Fonoaudiólogo e o seu grupo de referência. Os conteúdos nesse nivel são derivados da socialização do saber fonoaudiológico, adquirido através da educação formal. O segundo nivel investigado foi o da prática cotidiana, que se referia à experiência pessoal no nivel da prática profissional efetiva. Nesse segundo momento buscou-se aprofundar na compreensāo do processo de "ancoragem", ou seja, na inserção de experiências nas representações préexistentes sobre a prática fonoaudiológica.

Para a coleta de dados referente ao nivel da consciência compartilhada foram entrevistados 20 Fonoaudiólogos. Destes, apenas 5 participaram da segunda etapa no nível da prática cotidiana. 


\subsection{Procedimentos para Estudo da Consciência Compartilhada.}

A técnica utilizada para a coleta de dados foi a associação de idéias, conforme sugerido por Spink \& Gimenes (1994). A escolha se deu pois a técnica possibilita uma análise multivariável que, propicia condições favoráveis de interpretação na análise de conteúdo dos discursos.

Foram realizados três estudos pilotos, com diversas entrevistas cada um, até que se chegasse à versão final de um roteiro para coleta de dados. As entrevistas-piloto foram de fundamental importância para o refinamento do próprio roteiro a ser utilizado, e principalmente para que pudéssemos nos familiarizar com o tipo de procedimento metodológico escolhido.

Os relatos foram todos gravados com um minigravador cassete, com o consentimento de cada entrevistado. Além da gravação, foi pedido a cada entrevistado que escrevesse em uma folha de papel todas as associações ocorridas. Foram utilizadas 3 palavras eliciadoras para a associação de idéias: FONOAUDIOLOGIA, SAÚDE E FONOAUDIOLOGIA NA ATENÇĀO PRIMÁRIA. A associação de idéias para a palavra SAÚDE foi utilizada apenas como um intermediário para se chegar à Atenção Primária à Saúde, uma vez que esse era o foco central deste estudo. Apresentaremos um exemplo de uma situação de entrevista realizada:

"Eu queria que você me falasse e escrevesse neste papel, tudo que te vem à cabeça quando você vê a palavra FONOAUDIOLOGIA"

"terapia...terapeuta...audição e linguagem...cisão...integração...sempre me vem isso na cabeça...integração, transformação...valorização...construção" 
Após a associação, era perguntado aos entrevistados se aquela associação era considerada POSITIVA ou NEGATIVA, e que se manifestassem sobre o POR QUĖ da qualificação da associação.

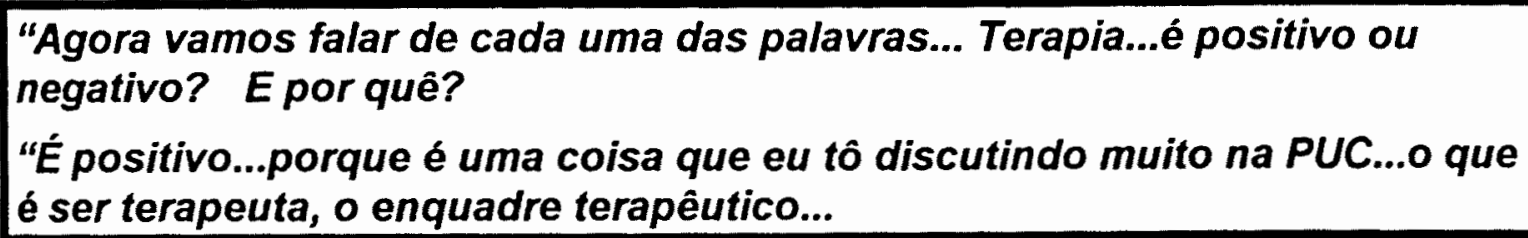

O mesmo procedimento foi utilizado para as palavras eliciadoras SAÚDE e FONOAUDIOLOGIA NA ATENÇÃO PRIMÁRIA, seguindo a mesma proposta descrita acima. Apresentaremos um pequeno trecho descrito para maior esclarecimento da técnica utilizada:

"Vamos fazer a mesma coisa com saúde...Tudo que te vier à cabeça com a palavra saúde..."

"promoção...doença...resgate...situação...politica...social...cultural...familia... contexto...ambiente...acho que inicialmente é isso..."

"Por quê você pensou promoção? É positivo ou negativo?"

"Veio uma coisa assim, como se fosse o inicio da saúde. Seria a coisa maior da saúde. Assim, a coisa da promoção...do cuidar da saúde. Muitas vezes...por isso que veio logo depois a doença. Promoção é positivo...Promoção como um cuidado. A saúde já é nossa, e muitas vezes a gente não consegue cuidar dela. Por isso que vem a doença. Um dos aspectos, é lógico. Mas promoção, como uma coisa que é nossa, que pode ser nossa. O cuidado com a nossa saúde. Positivo

"Doença?"

"Doença como um aspecto negativo. Vamos pensar aqui, né? Você pensa saúde, você pensa direto isso, o contrário de doença. 0 jeito que a gente foi aprendendo o que era saúde. O que era saúde? Era resgatar aquilo que está doente. Acho então que tem a questão do jeito como a gente foi aprendendo... 


\subsection{Procedimentos para Estudo da Prática no Cotidiano.}

Foram escolhidos 5 profissionais de forma aleatória e que, no momento do contato telefônico para o agendamento do encontro, se colocaram disponívels para uma entrevista mais longa e aprofundada. Para esses 5 entrevistados o roteiro incluiu mais três aspectos a serem coletados.

O primeiro dado a ser coletado dados para a análise no nivel da prática do cotidiano foi quanto às mudanças ocorridas ao se pensar cada um dos aspectos questionados. Em outras palavras, foi perguntado ao entrevistado se ele sempre havia pensado a FONOAUDIOLOGIA, a SAÚDE e a FONOAUDIOLOGIA NA ATENÇÃO PRIMÁRIA daquela forma, como pensava antes e o que havia feito para que sua opinião mudasse. As seguintes perguntas eram formuladas aos entrevistados, no final da positivação ou negativização das associações eliciadas:

"Você sempre pensou Fonoaudiologia assim? Como você pensava antes? O que fez você mudar?"

O mesmo procedimento foi realizado com SAÚDE e FONOAUDIOLOGIA NA ATENÇÃO PRIMÁRIA.

O segundo dado a ser coletado tinha como objetivo que o Fonoaudiólogo entrevistado argumentasse favorável ou desfavoravelmente quanto ao ingresso como profissional da saúde nos serviços públicos do município. Era solicitado ao entrevistado que convencesse o entrevistador a realizar o concurso para ingresso nos serviços públicos.

"Faça de conta que eu vou prestar um concurso para trabalhar no serviço público. Me convença ou não a prestar esse concurso..." 
O último dado coletado referia-se às atividades desenvolvidas pelo profissional na unidade de saúde. O profissional era solicitado a resumidamente descrever suas atividades na Ụnidade Básica de Saúde. Novamente, o objetivo dessa pergunta era o de obter produçōes discursivas que apresentassem argumentação possivel de ser analisada quanto aos interlocutores encontrados, contradições, ambigüidades e incoerências:

"Me conte um pouco o que você faz na sua rotina. Quais são as suas atividades?

\subsection{A escolha dos Sujeitos}

\subsubsection{O Universo dos Fonoaudiólogos no Municipio de São Paulo}

Para a escolha dos sujeitos foi realizado um levantamento do universo total de Fonoaudiólogos que atuavam nos serviços públicos de saúde, tanto na esfera Municipal como na esfera Estadual. Tais levantamentos foram realizados junto às Coordenadorias de Recursos Humanos da Secretaria Municipal de Saúde e da Secretaria de Estado da Saúde. Foram fornecidos o nome dos Fonoaudiólogos e as unidades nas quais prestam seus serviços. Vale ressaltar que estes dados foram fornecidos em 1995, antes da implantação do Plano de Atendimento a Saúde no Município de São Paulo.

$\mathrm{Na}$ época, o número de Fonoaudiólogos que atuavam na Secretaria Municipal de Saúde era de 186, sendo que destes $113(60,7 \%)$ atuavam em Unidades Básicas de Saúde.

É possivel se notar portanto, que a maioria dos Fonoaudiólogos que atuavam na Secretaria Municipal de Saúde exercia suas atividades em Unidades 
Básicas de Saúde, no nivel de Atenção Primária em Saúde. Esses Fonoaudiólogos estavam distribuídos pelo Município de São Paulo, nas 10 Administrações Regionais de Saúde - ARS - divisão administrativa na área da saúde ${ }^{1}$.

No que se refere aos Fonoaudiólogos dos quadros da Secretaria do Estado da Saúde, segundo informações da Coordenadoria de Recursos Humanos, 108 profissionais fonoaudiólogos exerciam suas funções em diferentes unidades de saúde, em 24 Direções Regionais de Saúde ${ }^{2}$ - DIRs - divisão administrativa de saúde na esfera estadual. Destes, 43 atuavam no municipio de São Paulo, sendo que 23 (53,5\%) atuavam em Unidades Básicas de Saúde.

Para que pudéssemos ter uma melhor visualização da distribuição geográfica dos fonoaudiólogos que atuavam na esfera estadual dentro do município de São Paulo, optamos por distribuí-los no mesmo mapa com as divisões administrativas utilizadas pela Secretaria Municipal de Saúde de São Paulo, ou seja nas dez diferentes ARSs. Desta forma foi possível observar inclusive as diferenças numéricas entre os fonoaudiólogos da esfera municipal e estadual.

O MAPA 1, portanto, ilustra a distribuição dos fonoaudiólogos que atuam no município de São Paulo em Unidades Básicas de Saúde, seja na esfera municipal ou estadual, segundo as dez diferentes Administrações Regionais de Saúde.

\footnotetext{
'O Anexo 1 mostra a divisão das 10 Administrações Regionais de Saúde no Município de São Paulo e os Distritos de Saúde e Distritos Administrativos da competência de cada Administração. ${ }^{2} O$ Anexo 2 mostra a divisão das 24 Direçōes Regionais de Saúde no Estado de São Paulo e os Municípios de competência de cada Direção.
} 
MAPA 1 - MAPA DO MUNIICÍPIO DE SÃO PAULO COM DISTRIBUIÇĀO DOS FONOAUDIÓLOGOS LOTADOS EM UNIDADES BÁSICAS

DE SAÚDE DA SMS E SES

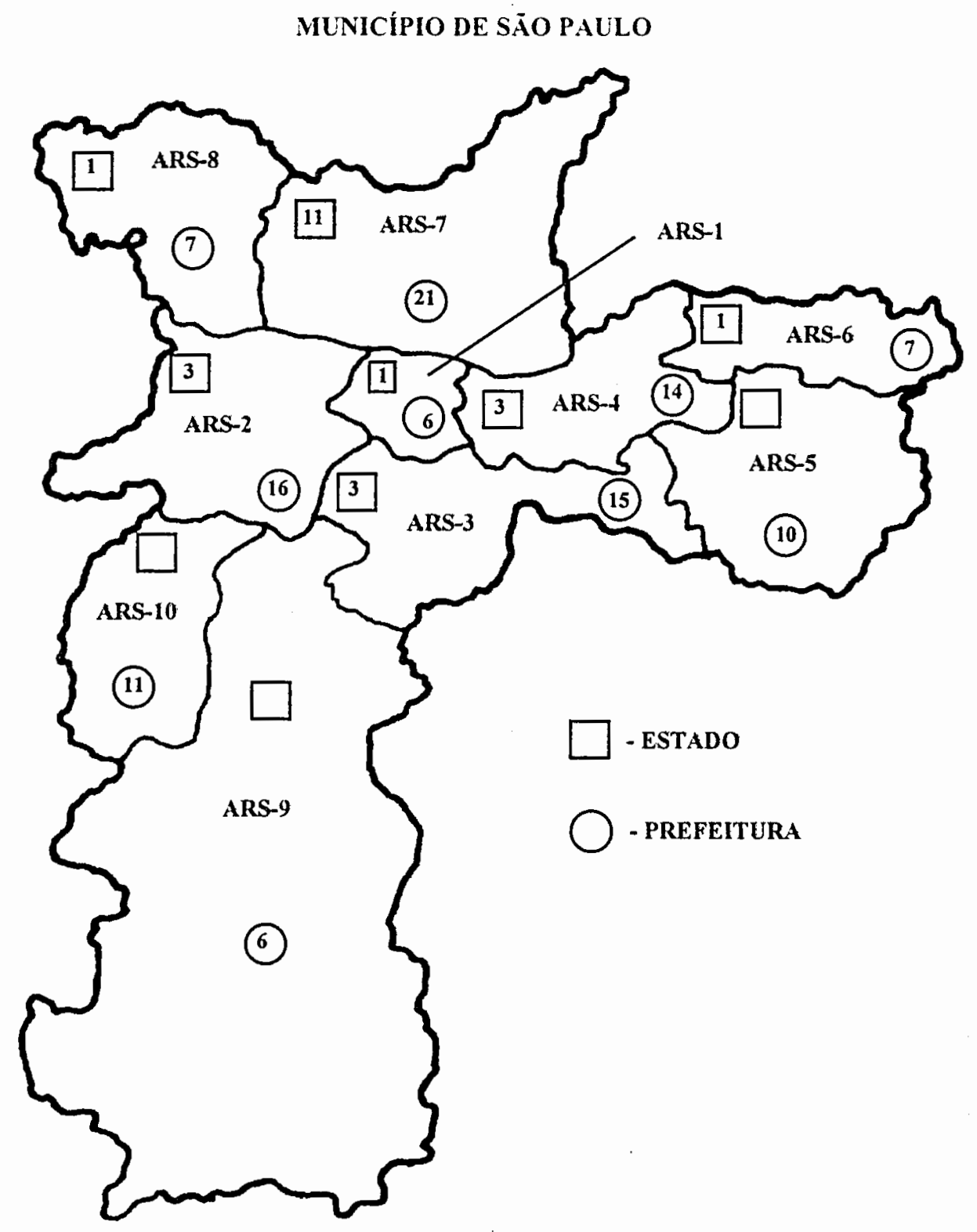

FONTE: Mapa CEPI - SMS - N de FONOAUDIÓLOGOS: CRH, SMS e SES (dezembre / 1995) 


\subsubsection{Escolha e Caracterização dos Sujeitos}

Após essa caracterização do universo total de Fonoaudiólogos atuando no Municipio de São Paulo, optamos por escolher 2 profissionais de cada Administração Regional de Saúde, preferencialmente um que atuasse na esfera Municipal e um na esfera Estadual. A opção por dois profissionais de cada região se deu para que pudéssemos ter uma amostra diversificada de fonoaudiólogos que atuam em todas as regiões do município de São Paulo e de ambas as esferas municipal e estadual.

A escolha foi aleatória, feita por sorteio. O contato com o Fonoaudiólogo foi feito por telefone, explicando-se superficialmente a pesquisa e a necessidade de um contato pessoal para uma entrevista. No caso do Fonoaudiólogo sorteado não ser encontrado após três tentativas, o próximo profissional da lista era escolhido para a entrevista.

Não foi possivel entrevistarmos um Fonoaudiólogo de cada região e contratado pela esfera estadual, uma vez que não encontramos profissionais suficientes para essa escolha. Foram então entrevistados 20 Fonoaudiólogos, sendo que 5 são do quadro da Secretaria de Estado da Saúde e 15 da Secretaria Municipal de Saúde. O GRÁFICO 1 descreve o número de profissionais entrevistados por Administração Regional de Saúde, não demonstrando sua esfera de atuação para que não haja identificação de nenhum entrevistado: 


\section{Gráfico 1 \\ DISTRIBUIÇÃO DOS FONOAUDIÓLOGOS \\ ENȚREVSTADOS SEGUNDO \\ REGIÄO (ARS)}

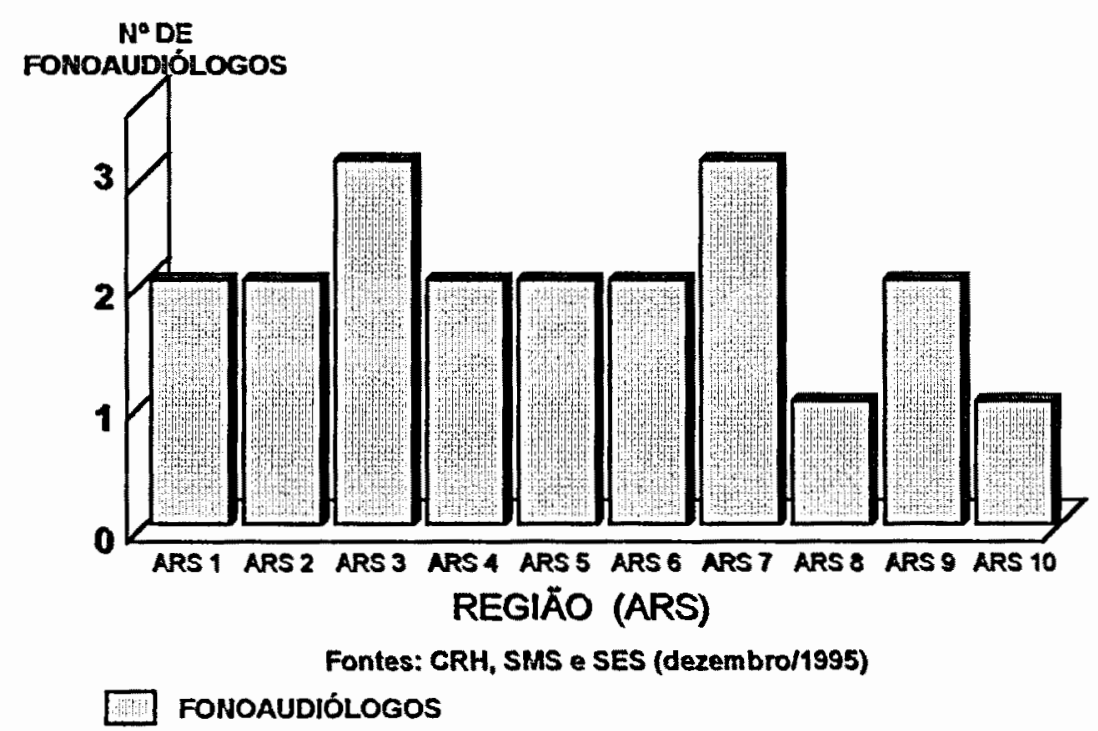

Não foi possivel entrevistar 2 profissionais de ARS 8 e ARS 10. Após várias tentativas de se localizar os profissionais, foi possivel agendar apenas uma entrevista em cada uma dessas regiões. O fato da coleta de dados ter sido realizada durante os meses de dezembro e janeiro colaborou para que os profissionais não fossem encontrados, pois muitos gozavam de suas férias anuais. Portanto, optou-se por entrevistar 3 profissionais de ARS 3 e 3 profissionais de ARS 7, uma vez que existiam mais profissionais nessas regiões.

No início da entrevista, foi feita uma breve caracterização dos sujeitos. Foram perguntados aos entrevistados: idade, local de formação profissional, ano de formação, tempo de trabalho em Unidades Básicas de Saúde, experiência em outras atividades. Foi ainda anotado o sexo dos entrevistados. 
No que se refere à experiência profissional, não foram observadas diferenças entre os profissionais entrevistados. Todos os profissionais tinham como experiência profissional o atendimento clínico individual em consultórios particulares e dois já haviam trabalhado em clínicas ou instituições com atendimento clínico multiprofissional. Dois entrevistados são docentes em Cursos de Fonoaudiologia de São Paulo e Grande São Paulo, e um terceiro já havia tido essa experiência por tempo reduzido no passado. Apenas um Fonoaudiólogo entrevistado havia trabalhado tanto na esfera municipal como na esfera estadual.

No que se refere à idade, local de formação profissional, tempo de formação e tempo de trabalho em Unidades Básicas de Saúde, os GRÁFICOS 2 a 5 demonstram quais eram as características dos sujeitos entrevistados:

\section{Gráfico 2 DISTRIBUIÇĂO DOS FONOAUDIÓLOGOS \\ ENTREVISTADOS SEGUNDO IDADE}

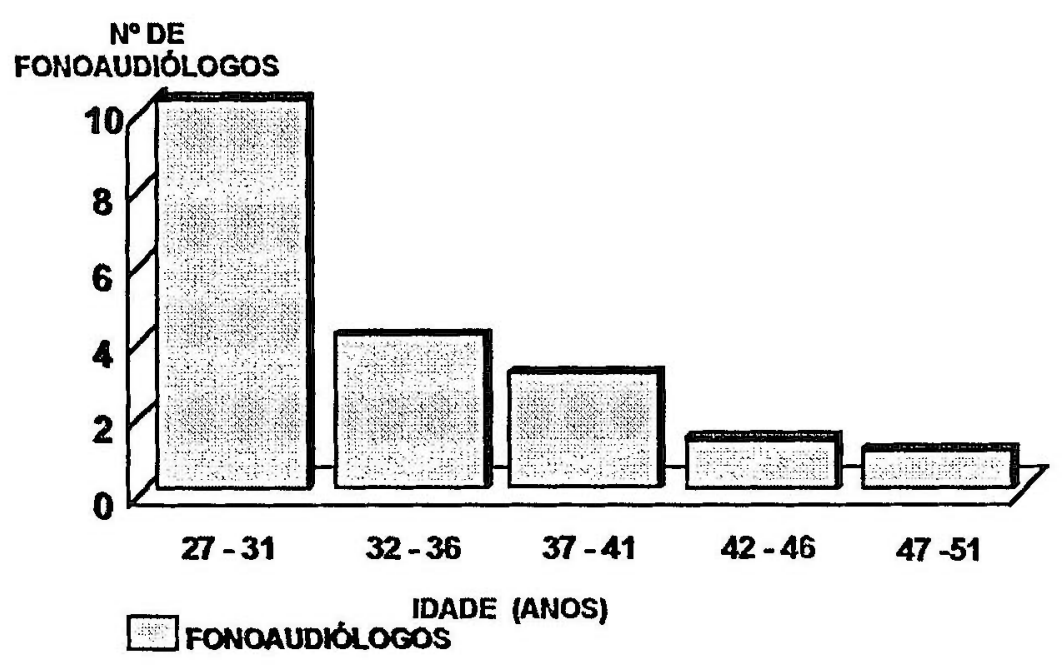


Os entrevistados tinham de 27 a 51 anos de idade, sendo que 10 entrevistados (50\%) se encontravem na faiva stária entre 27 e 31 anos de idade.

\section{Gráfico 3 \\ DISTRIBUIÇĀO DOS FONOAUDIÓLOGOS \\ ENTREVISTADOS SEGUNDO \\ LOCAL DE FORMAÇĀO}

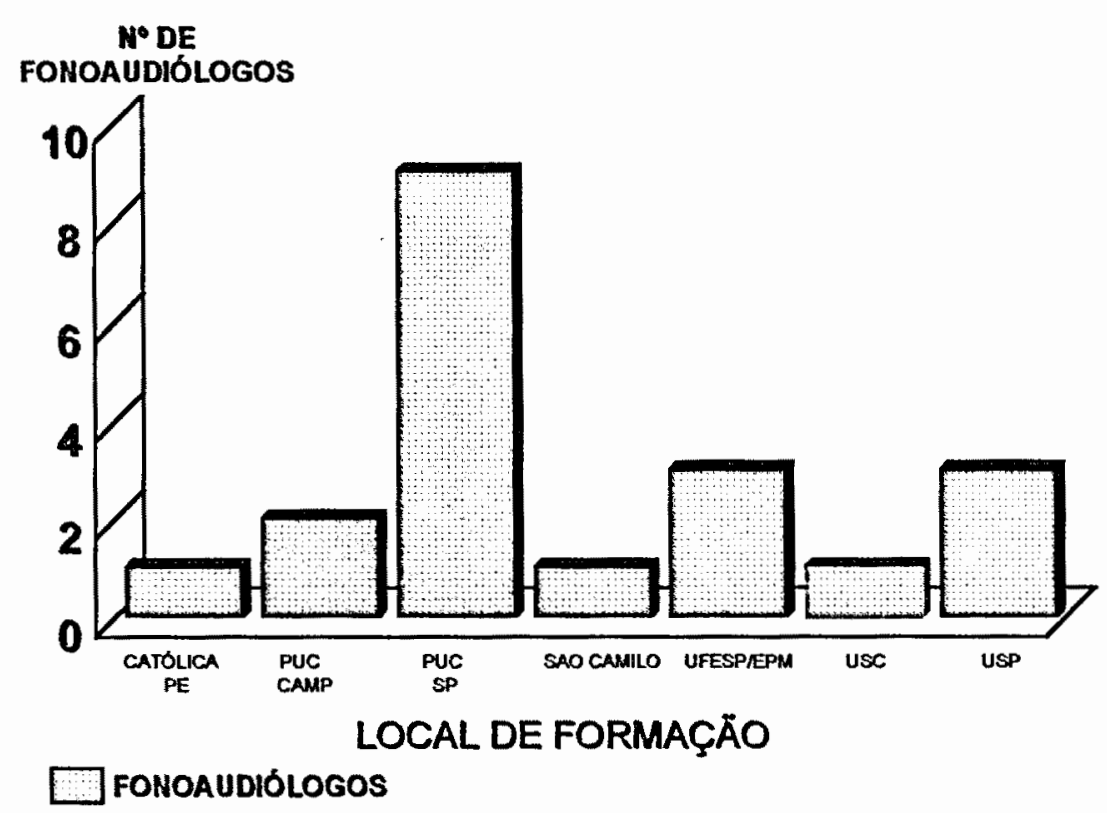

Quanto ao local de formação, pode-se observar que 9 entrevistados, (45\%), formaram-se no Curso de Fonoaudiologia da PUC-SP. Como a escolha dos sujeitos foi feita aleatoriamente, não houve a intenção de um maior número de entrevistas de uma mesma universidade. O fato do número de vagas para o Curso de Fonoaudiologia da PUC-SP ser 3 a 4 vezes maior do que em outros cursos no Município de São Paulo, pode ter propiciado um número maior de entrevistados dessa universidade. 


\section{Gráfico 4 \\ DISTRIBUIÇÃO DOS FONOAUDIÓLOGOS \\ ENTREVISTADOS SEGUNDO \\ ANO DE FORMAÇÄO}

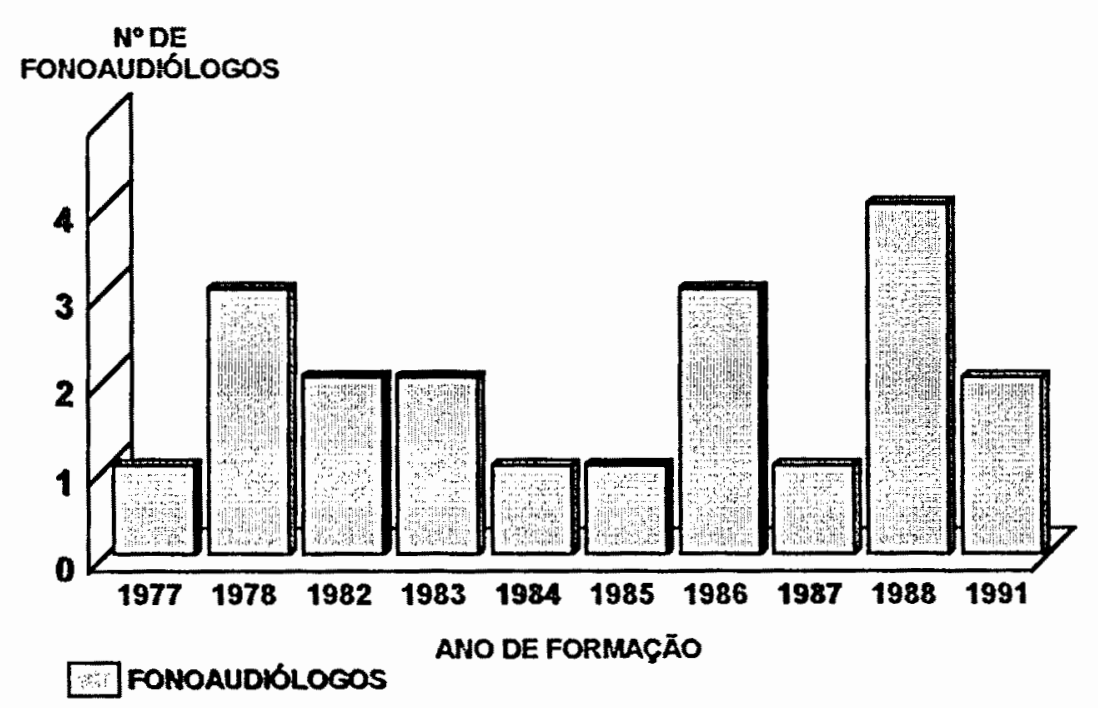

Quanto ao ano de formação, os profissionais haviam se formado entre 1977 e 1991. Um número maior de formados em 1988 pode ser observado e provavelmente se deva ao fato do concurso da Prefeitura Municipal ter se dado no ano de 1989. 


\section{Gráfico 5 \\ DISTRIBUIÇĀO DOS FONOAUDIÓLOGOS \\ ENTREVISTADOS SEGUNDO \\ TEMPO DE TRABALHO EM UBS}

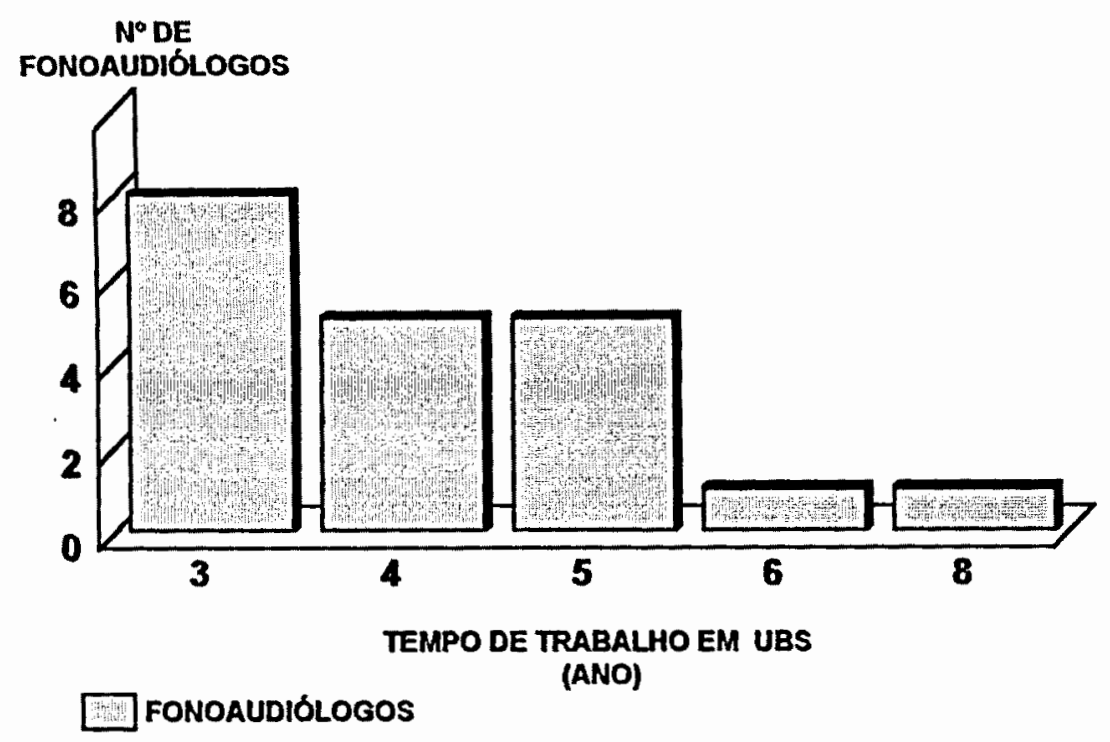

Os fonoaudiólogos entrevistados trabalhavam de 3 a 8 anos em UBS, sendo que 18 deles (90\%) possuiam de 3 a 5 anos de experiência em UBS.

\subsection{O contexto das Entrevistas}

É importante ressaltar que todos os Fonoaudiólogos contatados mostraram disponibilidade para conceder a entrevista. Do total de 20 entrevistas, 16 foram realizadas nos próprios locais de trabalho dos Fonoaudiólogos entrevistados. Apesar de extremamente trabalhosa, foi uma etapa muito interessante da pesquisa, uma vez que nos foi possivel conhecer fisicamente os locais de trabalho dos entrevistados, a distância dos locais a partir do centro da cidade de São Paulo, o tempo gasto em transporte, e as próprias condiçōes dos locais de trabalho dos profissionais entrevistados. As entrevistas realizadas nas Unidades Básicas de Saúde ocorreram todas nas próprias salas dos Fonoaudiólogos, fossem elas de uso exclusivo ou não desse profissional. Alguns Fonoaudiólogos ao final da entrevista, nos mostraram a Unidade Básica de Saúde. 
No contato telefônico, o profissional era informado sobre o assunto da pesquisa. Ou seja, era informado que a entrevista se referia ao trabalho do Fonoaudiólogo no nivel de Atenção Primária à Saúde. Geralmente nesse telefonema já era marcado o dia e horário para as entrevistas, sendo que o Fonoaudiólogo explicava como poderiamos chegar ao local da Unidade Básica de Saúde, dando algumas referências que pudessem tornar mais fácil o seu acesso. Duas entrevistas foram feitas nas casas dos entrevistados, por escolha própria deles, sendo que um teve a preocupação de que não conseguiriamos encontrar a Unidade Básica de Saúde. Um entrevistado preferiu dar a entrevista em seu consultório particular, e um outro no local de trabalho da pesquisadora.

No momento da entrevista, novamente explicávamos que nosso trabalho se referia ao papel do Fonoaudiólogo no contexto da Atenção Primária à Saúde, e que a entrevista seria um pouco "diferente" não havendo perguntas diretas. Logo em seguida, coletávamos os dados referentes às caracteristicas de cada entrevistado (idade, local de formação etc.) para depois iniciar a associação de idéias. Apenas um entrevistado demonstrou desconforto com o fato da entrevista estar sendo gravada, porém só manifestou claramente esse sentimento após o término da entrevista. Todos os entrevistados foram estimulados a declarar todas as suas opiniões, garantindo-se que não haveria identificação desses profissionais.

Alguns entrevistados manifestaram conhecer a pesquisadora, no contato telefônico ou pessoalmente no momento da entrevista. Não foram eliminados esses Fonoaudiólogos, pois não pareceu que havia uma interferência desse conhecimento no que se refere à entrevista. 
No final da entrevista, alguns Fonoaudiólogos manifestaram interesse em saber um pouco mais sobre a pesquisa, e principalmente sobre a técnica utilizada.

As entrevistas para coleta de dados para o nivel de consciência compartilhada demorou entre 15 e 30 minutos. Já as entrevistas que incluiram as perguntas para o nível da prática cotidiana demoraram entre 45 e 60 minutos.

\subsection{A análise dos dados}

\subsubsection{Transcrição de Fitas}

Após a coleta dos dados por meio de entrevistas gravadas, as fitas foram transcritas, em linguagem coloquial pela própria pesquisadora. As pausas e hesitações foram marcadas com três pontos (...). Quando houve risos, estes também foram transcritos. Ao final da transcrições foram obtidas 140 páginas com os discursos dos 20 sujeitos entrevistados. Duas entrevistas na integra podem ser encontradas no Anexo 3.

\subsubsection{Leitura Flutuante}

A primeira tarefa após a transcrição das fitas foi a leitura flutuante dos discursos dos entrevistados. Ou seja, as leituras foram realizadas com o objetivo de se iniciar um aprofundamento do conteúdo revelado, o que possibilitou que emergissem as unidades de significação. 


\subsubsection{Mapeamento das Entrevistas}

Os dados coletados nas entrevistas foram transcritos para diiversos mapas que continham todas as associações feitas para cada uma das palavras eliciadoras, com sua explicação positivada e negativada.

O primeiro mapa teve como objetivo sintetizar as associações de idéias positivadas e negativadas, que foram encontradas em cada entrevista e para cada palavra eliciadora. Foram construidos 3 mapas para cada entrevistado, cada um referente às 3 palavras eliciadoras utilizadas - Fonoaudiologia, Saúde e Fonoaudiologia na Atenção Primária. Nessa etapa foram construidos para os 20 entrevistados, portanto, 60 mapas. Os MAPAS 2 a 4 referem-se aos mapas construidos para um entrevistado e foram colocados no ANEXO 4 como exemplo.

Os primeiros mapas possibilitaram gerar categorias analiticas a partir das associações encontradas, sendo que as categorias visavam apreender a função do conteúdo associativo. Essas categorias são:

Essência :associações relacionadas à natureza intrinsica da Fonoaudiologia, Saúde e Fonoaudiologia na Atenção Primária.

Objeto: caracterizado pelo objeto alvo da ação.

Mediador: caracterizado pela forma como se alcançam os objetos.

Qualificador: os investimentos afetivos, os facilitadores e os obstáculos da ação.

Mostraremos alguns exemplos que esclarecem a categorização realizada, para a palavra eliciadora Fonoaudiologia: 




Um segundo mapa foi construído com o objetivo de mostrar a síntese das categorias em cada entrevista, e para cada palavra eliciadora. Por meio desse mapa é possivel observar quais foram as associaçōes que cada entrevistado realizou, e suas respectivas classificações nas categorias analíticas. Foram construidos nessa segunda etapa os MAPAS 5 a 7 e que podem ser encontrados nO ANEXO 5.

O terceiro mapa tinha como objetivo agregar as associações de todos os entrevistados buscando os conteúdos compartilhados. Nessa terceira etapa foram construidos 3 mapas, cada um correspondendo à cada uma das palavras eliciadoras. As FIGURAS 1, 3 e 5 correspondem aos referidos mapas e podem ser encontradas nas páginas 94, 109 e 117.

Finalmente, o quarto mapa buscava entender o núcleo central das representações e sua valoração. Foram construídos, para tanto, mapas que apresentavam as primeiras associações que ocorreram aos 20 entrevistados e suas respectivas valências. Foram construídos 3 mapas, novamente cada um correspondendo à cada uma das palavras eliciadoras. As FIGURAS 2, 4 e 6 correspondem aos referidos mapas e podem ser encontradas nas páginas 107 , 115 e 126. 


\subsubsection{Análise das Representações Sociais na Prática do Cotidiano}

De modo a entender como as Representações Sociais são colocadas em movimento na prática do cotidiano, foi realizada uma análise em profundidade dos dados encontrados nas cinco entrevistas que continham um roteiro mais extenso.

Tal análise foi pautada na temática central encontrada após a análise da consciência compartilhada. Ou seja, a partir das representaçōes analisadas no nivel da consciência compartilhada, serão analisados os discursos dos 5 entrevistados que responderam a mais três perguntas, buscando-se a produção do sentido na interface da prática do cotidiano. 


\subsection{Consciência compartilhada da prática fonoaudiológica em Atenção Primária à Saúde}

Conforme já citado no Item 3., a análise dos dados buscou evidenciar, num primeiro momento, as representações sociais, ou consciência compartilhada, de 20 Fonoaudiólogos quanto a Fonoaudiologia, a Saúde e a Fonoaudiologia na Atenção Primária à Saúde. O primeiro passo para a análise foi a criação de mapas para que pudéssemos sistematizar os conteúdos encontrados. A descrição quanto à elaboração dos mapas pode ser encontrada no Item 3. Procedimentos de Coleta e Análise dos Dados.

\subsection{A Palavra Eliciadora Fonoaudiologia}

O primeiro mapa, apresentado na FIGURA 1, mostra o conjunto das associações realizadas pelos entrevistados, quando a palavra FONOAUDIOLOGIA foi apresentada. Esse mapa sintese permite visualizar as associações do conjunto dos entrevistados por categoria, sendo assinaladas, conforme indicado na legenda, as frequências com que cada associação aparece e sua valência - positiva, negativa ou neutra. 
Figura 1: Conjunto das associações categorizadas e suas respectivas freqüências positivadas e negativadas, para a palavra eliciadora FONOAUDIOLOGIA.

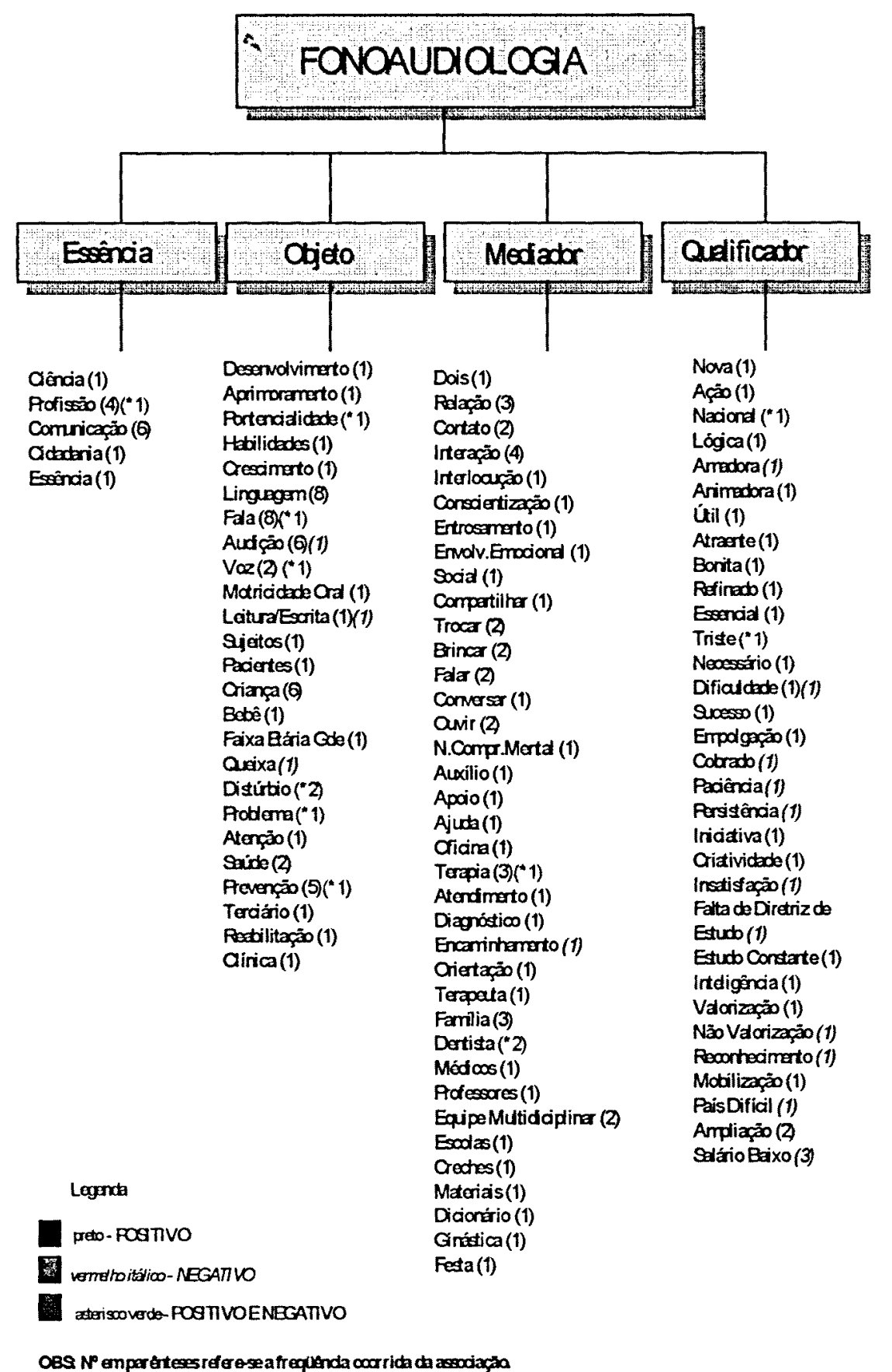

Por meio desse mapa pode-se observar que os entrevistados mostraram grande criatividade ao associar idéias à palavra eliciadora FONOAUDIOLOGIA, tendo feito diversas associações que puderam ser classificadas nas quatro categorias escolhidas. 
Conforme pode ser confirmado no MAPA 5, (ANEXO 5), apenas três dos entrevistados fizeram associações relacionadas a apenas uma categoria. $O$ entrevistado $n^{\circ} 3$ realizou todas as suas associações para a palavra FONOAUDIOLOGIA com seu, objeto de trabalho, ou seja, as ações preventivas e no nivel terciário de atenção à saúde - a reabilitação; também associou a uma faixa etária grande. Os entrevistados $n^{\circ} 10$ e 20 mostraram todas as suas associações relacionadas ao qualificador da palavra eliciadora. No entanto o entrevistado $n^{\circ} 10$ qualificou a profissão de forma totalmente negativa, mostrando seu descontentamento em relação à Fonoaudiologia. De forma oposta, o entrevistado $n^{\circ} 20$ qualificou a Fonoaudiologia positivamente, mostrando outra relação afetiva com a profissão, pelo menos no momento da entrevista.

Para a palavra FONOAUDIOLOGIA, os entrevistados fizeram um maior número de associações nas categorias objeto e mediador. Na categoria objeto mostraram que as associações de idéias mais freqüentes eram aquelas que se relacionavam diretamente ao objeto de trabalho - linguagem, fala, voz, audição ou prevenção por exemplo, e também àqueles a quem o trabalho é dirigido - mais especificamente à criança. Na categoria mediador, os entrevistados associaram com maior freqüência interação e terapia, considerados como essenciais para se conseguir chegar ao objeto da profissão, a linguagem e o tratamento dos distúrbios da comunicação.

Dos 20 entrevistados, 10 sujeitos (50\%) fizeram associaçōes relacionadas à essência da palavra eliciadora. As associações foram na sua maioria com relação à comunicação, essência principal e direta da profissão.

A partir do mapa apresentado na FIGURA 1, foram realizadas as análises das associações que se mostraram significativas devido a sua recorrência no discurso dos entrevistados. Dessa forma, as associaçōes que foram feitas por apenas um entrevistado não serão aqui enfatizadas. 


\subsubsection{A Essência da Fonoaudiologia}

Os fonoaudiólogos entrevistados realizaram 14 associaçōes que puderam ser categorizadas como essência, ou seja, a natureza ou razāo principal da prática fonoaudiológica. Esta categoria foi a que ocorreu com menor freqüência, sendo que as associações foram na sua maioria positivas. Apenas um entrevistado apresentou uma associaçāo que tinha ambos os aspectos (positivo e negativo). Duas foram as associações mais freqüentes nesta categoria profissão e comunicação.

É natural que uma das associações realizadas para a palavra eliciadora FONOAUDIOLOGIA seja profissão. Colocam os entrevistados tanto a profissão como algo que escolheram por vontade própria, assim como também por ser o trabalho uma das fontes de realização pessoal e satisfação do ser humano:

"Foi algo que eu escolhi para fazer..."

"Se eu tivesse que voltar atrás eu escolheria de novo..."

"...meu trabalho... que eu gosto e que é grande parte da minha vida..."

Apenas uma das associaçōes com a profissão teve aspectos positivos e negativos. Positivo pela possibilidade de desenvolver um trabalho colocado como "ideal" e negativo pela falta de infra-estrutura que a instituição para a qual o entrevistado presta seus serviços oferece. Pode-se analisar, portanto, que os entrevistados mostram-se satisfeitos ao se referirem à profissão a qual escolheram.

Quanto à comunicação, pode-se notar que os entrevistados colocam apenas parcialmente a importância da comunicação para o homem, sem deixar de lembrar que a Fonoaudiologia irá trabalhar com aquele que tem um distúrbio da comunicação:

"... a questão do tornar comum, do poder partilhar fala, contexto, dividir..." 
"... prá desenvolver comunicação... no sentido de melhorar mesmo..."

"...é a essência do ser humano."

"...por permitir a interação entre as pessoas..."

"... que a pessoa consiga șe expor de alguma forma... aquilo que ela quer..." "... é uma palavra muito mais ampla do que a Fono... tem a televisão, o rádio...e a fono ajuda as pessoas que têm algum tipo de dificuldade... não só dificuldade...

O fato do Fonoaudiólogo se referir à comunicação dessa forma pode ser esclarecido, uma vez que pode-se considerar comum que os discursos cientificos e acadêmicos em Fonoaudiologia estejam mais voltados para a linguagem e para a fala do que para a comunicação. Os conceitos de comunicação, linguagem e fala aparecem misturados, não ficando clara a troca de informações existente durante o processo de comunicação. A comunicação pressupõe que exista um código comum entre os sujeitos, para que a troca possa ocorrer. A linguagem, entendida como uma atividade simbólica, faz uso de um ou de vários códigos como forma de expressão, sejam eles os gestos, a arte, a música, as expressões faciais ou a fala. A linguagem, implica necessariamente em uma representação por parte do sujeito, independente do código utilizado.

A palavra eliciadora FONOAUDIOLOGIA sugeriu ainda a associação com essência, ciência e cidadania, tendo aparecido, entretanto, apenas na associação de um sujeito. Tal fato nos faz concluir que essas associaçōes não parecem constituir elementos centrais da consciència compartilhada sobre Fonoaudiologia.

\subsubsection{O objeto da Fonoaudiologia}

Os fonoaudiólogos entrevistados realizaram 64 associaçōes que foram categorizadas como objeto de estudo da Fonoaudiologia. Essa foi a categoria em que surgiu o maior número de associações; no entanto, a maioria delas com baixa freqüência de repetição. Os entrevistados indicam, assim, que existe uma grande diversidade de aspectos relacionados com seu objeto de trabalho $e$ 
estudo. As associações mais numerosas foram, portanto, na categoria objeto, com o Fonoaudiólogo descrevendo o seu campo de atuação.

Se usarmos todas as associações encontradas, pode-se afirmar que o Fonoaudiólogo coloca seu campo de atuação voltado para o desenvolvimento, aprimoramento e crescimento, buscando as habilidades e potencialidades do sujeitos. Para tanto, atua especificamente na linguagem, fala, voz, audição, motricidade oral e leitura escrita, com bebês, crianças ou pacientes. Pode-se atuar com uma faixa etária grande. As queixas, problemas ou distúrbios terão a atenção do fonoaudiólogo seja para a sua prevenção ou, na clínica, para a reabilitação. Na saúde, a nomenclatura terciário é utilizada.

Mais uma vez pode-se evidenciar a diversidade de associações feitas pelos fonoaudiólogos entrevistados quando a palavra eliciadora FONOAUDIOLOGIA foi colocada. As respostas evidenciam que os entrevistados conseguem apontar seu campo de atuação, e novamente de forma bastante positiva. Foram poucas as associaçōes negativas. No entanto, a diversidade do campo de atuação também pode representar uma difícil delimitação do campo de atuação.

No entanto, nota-se que linguagem (8), fala (9), audição (7), prevenção (6) e criança (6) foram as associações mais recorrentes:

Os discursos abaixo podem ser considerados como uma mistura dos conceitos de comunicação e linguagem. Os entrevistados fundem os conceitos de comunicação, linguagem e fala, apesar da especialidade de sua atuação profissional. A troca, a relação interpessoal são lembradas nas associações:

"...de você poder ir construindo, né, a linguagem, uma fala, e poder estar trocando ela com o outro..."

“...é com a linguagem que a gente pode manter as relações... ela te possibilita...entrar em contato com o outro, entrar em contato com o nundo..." 
"... linguagem eu vou falar mais ou menos como a comunicação...pegar no individuo aquela linguagem que ele tem e mostrar tudo de bom da linguagem que ele tem..."

"...é você poder ter contato com o outro, se relacionar, se expressar...de todas as maneiras possiveis..."

No discurso a seguir, a fala, a linguagem e a audição foram conceituadas da mesma forma pelo entrevistado, novamente mostrando a não diferenciação entre as associaçōes, todas tomadas como uma habilidade do corpo humano. A associação parece representar uma visão reducionista, quando colocada isoladamente, pois aponta apenas para uma possibilidade orgânica do homem.

"... é uma habilidade... eu tô pensando no ... exercício de uma faculdade humana... de uma possibilidade do corpo..."

Nos dois trechos de discursos descritos abaixo, já se nota uma diferenciação entre os conceitos de comunicação e linguagem e das condições necessárias para que esta possibilite o desenvolvimento do individuo. Todo o raciocínio traçado a partir da associação tem uma lógica voltada para a necessidade da comunicação, por meio da linguagem, para que ocorra o desenvolvimento do homem. A interação torna-se fundamental tendo tanto o papel de objeto como de mediador, propiciando a comunicação, por meio da linguagem.

“... é o que possibilita a comunicação... se não tem linguagem... o paciente lá e eu aqui... não tem interação, não tem troca...não tem o desenvolvimento..."

“...porque eu penso na questão da interação das pessoas, de comunicação..."

A fala é considerada como um aspecto negativo quando se relaciona a um distúrbio. Apesar de ser parte do objeto com que lida a profissão, ao associar a 
fala a um distúrbio, o entrevistado faz uma associação negativa, principalmente na sua atuação institucional em Unidade Básica de Saúde:

“...o negativo, que ai entra a parte da fono, de distúrbio..."

A fala e a audição são associadas à linguagem e ao desenvolvimento do homem. Ambos fazem parte de um processo mais amplo, a comunicação, que possibilita o desenvolvimento humano.

"...inclui o desenvolvimento da pessoa como um todo..."

"...basicamente a Fonoaudiologia tem uma coisa de fala ... uma coisa da gente falar, se comunicar, entrar em contato... sem a fala ...ficaria dificil, né?"

"...a fono trabalha basicamente com fala...

"falar...é como uma forma de expressão...a gente lida muito com isso...a fono tem a coisa do falar bem, tentar se expressar bem, verbalmente..."

A fala, enquanto forma de expressão, é representada pelos entrevistados e tal fato parece coerente uma vez que esta é a dimensão da linguagem na qual o Fonoaudiólogo mais atua.

Ainda na categoria objeto foi possivel observar que os entrevistados associaram o seu campo de atuação significativamente à criança:

"...a criança sempre te dá uma resposta àquilo que você quer. E eu gosto muito de ver a criança crescendo e tudo que eu sei e aprendi sendo aplicado, e a criança respondendo a isso..."

"...a criança...é aquilo que eu falei...ela se torna um aliado...ela confia em você... ela é só um materialzinho que você tá só arrumando..."

"...o meu trabalho é maior com criança..."

"...eu atendo muita criança, né?... as crianças têm um lado assim, superbonito...um lado até mais ingênuo do que o adulto, então... vêm com toda a espontaneidade... 
O campo de atuação do fonoaudiólogo é grande com crianças, uma vez que se entende a prática fonoaudiológica ligada ao desenvolvimento das habilidades comunicativas, e principalmente responsável pelo tratamento e correção do padrão da fala. "Torna-se portanto natural que grande parte da demanda seja de crianças em processo de aquisição e desenvolvimento de linguagem oral, ou então aquelas que apresentam dificuldades na linguagem escrita no processo de alfabetizaçāo. Ao mesmo tempo, essas mesmas crianças, segundo os entrevistados, têm características no seu relacionamento, que tornam a atuação mais agradável e prazerosa para o profissional.

Os fonoaudiólogos entrevistados, ao associarem a palavra FONOAUDIOLOGIA às idéias de saúde e prevenção, assumem seus papéis de profissionais da saúde preocupados com uma atenção que privilegie tanto o preventivo como o curativo. Consideram a atuação preventiva mais abrangente, principalmente, mas não somente, quando se atua com crianças muito pequenas, orientando pais na prevenção de alterações que possam levar a distúrbios da comunicação:

"preventivo...acho que seja a realidade para um trabalho mais abrangente...com crianças pequenas, a nivel escolar..."

"a gente tem feito muito mais coisa preventiva... a gente tem a UBS, onde tem os bebezinhos...então, não tem como não ser preventivo..."

"porque...a gente vê o resultado assim...você vê o quanto você pode estar dando de dica, uma simples conversa, uma orientação...e estar prevenindo muita coisa..."

"porque vai estar tentando descobrir ou prevenir, antes que o mal se instale..."

No entanto, ainda há entrevistados que questionam o papel da Fonoaudiologia na prevenção e aqueles que acreditam que a prevenção está além dos limites da Fonoaudiologia. Os dois trechos descritos a seguir mostram 
que nem todos os profissionais têm as mesmas concepções sobre o trabalho preventivo em fonoaudiologia que vem sendo descrito inclusive na literatura:

"positivo, porque se você rrealmente souber o que você está querendo prevenir, se você sabe realmente o que é prevenção, você sabe como agir...negativo porque se você acha que prevenção é o ótimo, maravilhoso...e você não souber realmente o que você quer, você vira o jogo..."

"prevenção prá mim, acho que não é nem em Fonoaudiologia...acho que tem a ver com estar na UBS, né?..."

Os discursos apresentados acima mostram, em primeiro lugar, que talvez não se saiba o que e como prevenir em Fonoaudiologia. Mostram então, que prevenir pode, inicialmente, estar voltado às descobertas de necessidades talvez ainda não esclarecidas.

Por outro lado, aparece a representação de que a prevenção não está necessariamente voltada a ações especificas e segmentadas de uma área, mas sim à ações desenvolvidas por profissionais no nivel de Atenção Primária à Saúde. que partilham de um mesmo objetivo junto aos usuários de um serviço de saúde.

\subsubsection{Os Mediadores da Prática Fonoaudiológica}

Os entrevistados também utilizaram um grande número de associações relacionadas a "como" o fonoaudiólogo atua, ou seja, os subsídios e as técnicas necessárias para que seja possivel a atuação. Essas associações, categorizadas como mediadores, foram avaliadas como aspectos positivos, apesar de aparecerem com pouca recorrência. Foram realizadas 54 associações de idéias. apontadas como mediadores da prática fonoaudiológica. 
Os entrevistados sugerem que é necessária a relação, a interação, o contato, a interlocução, a dois, além da conscientização, do entrosamento, do envolvimento emocional para que um trabalho fonoaudiológico possa ocorrer na sua natureza, a comunicação. Sugerem ainda que o compartilhar, o trocar, o brincar, o falar, conversar e ò ouvir são fundamentais para uma relação entre os profissionais e aqueles que acabam por usufruir de seus serviços - os pacientes, familiares, usuários de serviços de saúde e outros profissionais. A associação feita com maior freqüência pelos entrevistados foi a interação (4):

“...interação está ligado a comunicação e linguagem...você se propõe a estar trocando..."

“...existe a relação, ser uma coisa afetiva...

“...interação... é o que a gente procura o tempo inteiro...porque se não tiver a interação a coisa não acontece..."

"...troca de experiências...da gente aprender também com os pacientes, com os pais..."

"...a gente usa muito o brincar com a criança...aí entra a linguagem, interação..."

É possivel notar que os entrevistados fizeram associações mais voltadas à afetividade ou emoção que possibilitam a comunicação, apontando uma concepção de linguagem mais voltada ao conteúdo e não à forma de expressão. Técnicas especificas, ou exercícios localizados para a adequação dos padrões de fala não foram muito mencionados. Nota-se uma contradição no discurso do profissional que ao mesmo tempo que busca o melhor desenvolvimento da comunicação humana através da interação, da troca e do relacionamento, tem a tarefa de fazer com que os individuos tenham a melhor fala possível. Ou seja, que possam se expressar verbalmente de forma correta e seguindo os padrões vigentes na sociedade da qual fazem parte. Isso pode ser localizado nos seguintes discursos:

"...a fono trabalha basicamente com fala... 
"falar...é como uma forma de expressão...a gente lida muito com isso...a fono tem a coisa do falar bem, tentar se expressar bem, verbalmente..."

Apenas um entrevistado considerou ainda a sua atuação como um auxilıo, um apoio ou uma ajuda, para aqueles que necessitam. As associações que surgiram como a forma de atuação foram para oficina, orientação, encaminhamento, diagnóstico, atendimento e com maior frequência a terapia fonoaudiológica (4). Os entrevistados mostram uma preocupação com o ser terapeuta e em como a terapia pode influir na vida de um individuo, inclusive estigmatizando-o ao invés de the propiciar condições de um maior desenvolvimento:

"...além dessa questão da terapia e do enquadre terapêutico, a gente olha muito o você terapeuta... não só o paciente, o enquadre, o lugar...mas como trabalhar enquanto terapeuta...

"a terapia eu vejo como positivo e negativo... você pode realmente intervir e ajudar...e negativo porque você também pode estigmatizar..."

"terapia...vai estar melhorando a vida...a condição da pessoa..."

Ainda como mediadores para a atuação do fonoaudiólogo foram encontradas associações com outros profissionais da saúde: o dentista, o médico e os professores. No entanto a familia foi considerada como subsídio importante para a atuação fonoaudiológica:

"...a familia... é a base de tudo...é essencial que a família esteja sempre bem estruturada..."

"...pais...sem eles o trabalho fura completamente..."

"...acho que é meio nessa idéia de ter os pais participando..."

A família e principalmente os pais são considerados parte integrante e fundamental da prática fonoaudiológica, principalmente ao se considerar que a faixa etária mais associada foi a criança. 
Foram apenas duas as associações referentes às técnicas especificas utilizadas pela FONOAUDIOLOGIA na sua prática profissional. A ginástica e 0 dicionário foram citados apenàs por um entrevistado. A ginástica como exercícios necessários para um bom desenvolvimento da motricidade oral, mas principalmente como uma forma de "exercitar a mente". O dicionário, como uma questão fundamental ligada ao fato de o especialista em comunicação e linguagem ter um vocabulário farto.

\subsubsection{Os Qualificadores da Prática Fonoaudiológica}

Os entrevistados fizeram 36 associações que de alguma forma qualificaram a FONOAUDIOLOGIA. Esse item possibilita analisar como 0 profissional dá sentido a sua profissão, que afetos são aí depositados. Apesar dos dados anteriores sugerirem anteriormente sugerirem que 0 profissional encontra-se satisfeito com sua escolha profissional, na categoria qualificadores emergem vários sentimentos negativos em relação a profissão, contrariando, ou balizando as colocações iniciais sobre a mesma. Também nessa categoria as idéias associadas foram as que menos se repetiram. A palavra FONOAUDIOLOGIA suscitou uma diversidade de idéias sobre a profissão, sua prática e também a sua relação com outros profissionais. A valorização ou falta de valorização da profissão e a baixa remuneração, no entanto, merecem serem comentadas pois totalizaram 5 associações em uma categoria onde as associações praticamente não se repetiram:

"valorização... eu pensei no meu trabalho aqui...a necessidade cada vez mais de cavar espaço, mostrar o que se faz...acho que ainda falta..."

"...ela (chefia), não sabia quem era fono, psico, fisioterapeuta, terapeuta ocupacional...ela não sabia direito o que cada um fazia...prá ela são coisas secundárias...então eu sinto um desprestígio...o pessoal não dá valor...a área médica não dá valor..."

"...não valorizado...familias...vêm procurar porque a professora diz que se não procurar ele vai repetir de ano...o valor é só esse...passar de ano...não interessa se ele aprendeu coisa na escola ou não...ou o que vai fazer da 
vida...professor também...ou vai ser incluido em terapia ou vai repetir de ano..."

“...não que ele seja valorizado só pelo salário... mas um aspecto que valoriza o profissional ... também é o salário..."

"...dificuldade...em relação ao financeiro mesmo...reconhecimento...eu também pensei em salário..."

Sente-se assim desvalorizado duplamente o profissional que não consegue fazer com que seu campo de atuação seja reconhecido por outros profissionais de saúde, e mais especificamente pelo médico. Sente-se ainda desvalorizado por ter que atender a uma população de escolares sob pressão da familia e dos professores, muitas vezes não acreditando ser a sua função, apesar de aparecer como uma demanda da população:

“...habitualmente eu respondo (aos professores)...aqui eu não faço reforço escolar...pode eventualmente ajudar na leitura...mas não é o meu objetivo principal..."

Sente-se desvalorizado por receber um salário que lhe impõe limitações inclusive para a continuidade de sua formação e aprimoramento profissional:

"...inclusive aparecem cursos que eu não tenho condições de fazer porque eu não tenho dinheiro..."

Existe assim uma relação entre as associações de idéias realizadas quanto a valorização profissional, reconhecimento, remuneração, dificuldade, mobilização e até mesmo a ampliação ou expansão da profissão. Pode-se analisar assim, que os aspectos negativos estão mais voltados para a visão que outros profissionais têm da profissão de fonoaudiólogo e principalmente quanto a sua remuneração. Mesmo a associação triste foi feita em função da valorização:

"...é triste porque as pessoas não dão o devido valor...” 
No entanto, um dos entrevistados referiu-se ao campo de atuação da FONOAUDIOLOGIA usando apenas qualificadores positivos: atraente, bonita, refinada e essencial.

A nuclearidade e valoração da profissão pode ser observada também a partir da análise da ocorrência da primeira associação, feita pelos entrevistados, com a palavra eliciadora FONOAUDIOLOGIA - FIGURA 2:

Figura 2: Ocorrência da primeira associação realizada pelos entrevistados, para a palavra FONOAUDIOLOGIA.

\begin{tabular}{||l|c|c|c||}
\hline Ocorrència & Positivo & Negativo & Neutro \\
\hline \hline Comunicação & 5 & & \\
\hline Terapia & 2 & & \\
\hline Faixa etária grande & & & 1 \\
\hline Audição & 1 & & \\
\hline Profissão & 2 & & \\
\hline Reabilitação & 1 & & \\
\hline Estudo da audição e fonoarticulatória & 1 & & \\
\hline Linguagem & 3 & & \\
\hline Salário baixo & & 1 & \\
\hline Fala & 1 & & \\
\hline Atraente & & & \\
\hline
\end{tabular}

Ao se analisar a primeira associação dos 20 entrevistados, pode-se observar uma grande variedade de palavras lembradas. No entanto a de maior freqüência foi comunicação (5), mostrando que os Fonoaudiólogos têm como enfoque principal na profissão uma das essências e natureza particular do homem que é a capacidade de se comunicar. A comunicação que significa transmitir e/ou receber qualquer tipo de mensagem falada, escrita, através de sinais e símbolos. 
A segunda associação ocorrida com maior frequência foi linguagem (3), que vem a ser uma das matérias primas e objeto de estudo principal da Fonoaudiologia, para que se alcance a comunicação. Fala, terapia e profissão foram as primeiras associaçōes de dois entrevistados. As outras seis associações encontradas ocorreram apenas uma vez cada uma.

Mais uma vez, pode-se observar na FIGURA 2 que, a maioria das primeiras associações foi considerada positiva.

\subsection{A Palavra Eliciadora Saúde}

As associações com a palavra eliciadora SAÚDE estão sintetizadas na FIGURA 3 que, através do mapa sintese nos permite visualizar as associações do conjunto dos entrevistados por categoria, sendo assinaladas conforme indicado na legenda, as frequências com que cada associação apareceu e sua valência - positiva ou negativa. 
Figura 3: Conjunto das associações categorizadas e suas respectivas freqüências positivadas e negativadas, para a palavra eliciadora SAÚDE

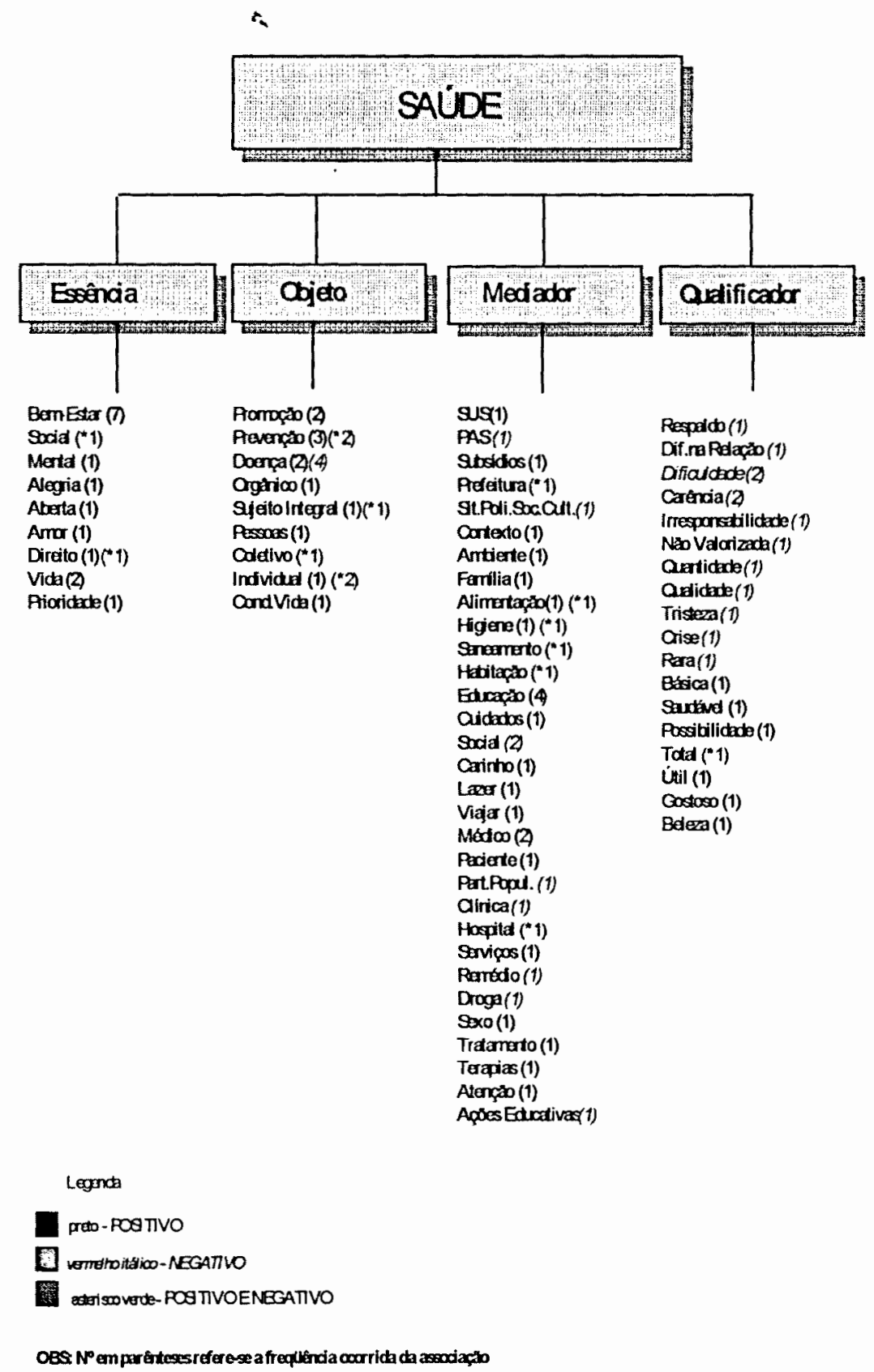

A palavra eliciadora SAÚDE suscitou idéias referentes às quatro categorias, embora um menor número de associações apareceu nas categorias essência e objeto. Bem-estar foi a associação mais frequente no conjunto das associações e foi por nós categorizada como a essência da SAÚDE. Na categoria objeto a associação mais prevalente foi a doença, seguida da 
prevenção. A categoria mediador apresentou uma grande diversidade de associações, que praticamente não foram repetidas pelos entrevistados. A mais recorrente foi educação. Já para a categoria qualificadores, não houve recorrência, a não ser para as associaçōes dificuldade e carência. O número de associaçōes para todas as categorias foi menor do que para a palavra eliciadora FONOAUDIOLOGIA.

\subsubsection{A Essência da Saúde}

Foram realizadas 18 associaçōes que puderam ser categorizadas como essência ou natureza da SAÚDE. A associação com bem-estar teve uma recorrência significativa, pois surgiu sete vezes entre os entrevistados. A análise deve ser feita pensando-se na definição clássica de saúde, "bem-estar bio-psicosocial e não simplesmente a ausência da doença." Vale ressaltar que nenhum entrevistado citou o processo saúde/doença em suas associações.

"é o bem-estar bio-psico-social...é...eu acredito nisso, né... mas eu não sei expressar com minhas próprias palavras..."

"penso só em coisas que sugerem o bem-estar... é mais que isso...é mais que só o bem-estar que seja físico... que seja emocional...é mais que isso..."

"saúde é bem-estar ... fisico... psiquico...é estar bem consigo mesma..."

"o bem-estar, eu pensei na questão física, emocional..."

Os entrevistados associam Saúde a uma definição, o bem estar, representando a saúde como estar bem, não sentir dor, ou seja, não estar doente. Aparece a dicotomia saúde $x$ doença nessa representação.

Apenas uma associação foi realizada e lembra uma conceituação de saúde um pouco mais abrangente, citando condições de vida como a essência da saúde. No entanto, essa associação não surge de forma recorrente. Observa-se que há uma necessidade ainda maior de se conhecer os processos 
determinantes do processo saúde/doença para que se possa pensá-lo como um resultado das condições de vida do homem.

"eu acho que saúde, tem a ver...também...com condições legais de vida...uma educação legal...com outras coisas que não a saúde relacionada a doença ou a ausência de doença..."

\subsubsection{O Objeto da Saúde}

21 associações foram verificadas como objeto da saúde. Entre essas é relevante o número de recorrências para doença (6) e prevenção (5). As associações sugerem uma coerência no discurso dos entrevistados. Ao associarem a doença com maior recorrência torna-se quase impossivel não associarem também a prevenção. Ao representarem o objeto da saúde como a doença, faz-se necessário que a prevenção também se transforme em objeto, como forma de se superar o único objeto com valência negativa.

“...doença é um estado que não è o natural...nas pessoas...não tem condições legais, educação, o ambiente..."

"eu acho que pelas próprias questōes de condições de vida e saúde, trabalho...que a gente tem...e que não dá pro individuo ter uma condição adequada de saúde..."

"saúde...você pensa direto o contrário...doença. O jeito que a gente foi aprendendo que era saúde...era resgatar aquilo que tá doente..."

Os discursos sugerem também que os sujeitos entrevistados iniciam um processo de modificação dessas representações pois, apresentam uma argumentação que indica que as condições de vida são objeto importante da saúde.

O trecho do discurso que se descreve abaixo mostra a carência de um aprendizado a respeito do assunto. A promoção da saúde e a prevenção das 
doenças são vistas como duas formas diferentes de se agir preventivamente. A prevenção onde se pensa na saúde e a prevenção onde se pensa na doença::

"tem uma prevenção que é. aquilo que você está pensando em saúde, e outra que você já pensa na doença...evitar que aquela coisa aconteça..."

Os conceitos de prevenção e promoção de saúde foram misturados, sendo ambos chamados de prevenção. O entrevistado provavelmente se refere à promoção de saúde quando pensa em uma "prevenção que está pensando na saúde". Ou seja, que condições de vida e trabalho estejam disponiveis a todos os segmentos para que possam resultar em melhores condições de saúde.

Tem-se outros exemplos da confusão entre promoção de saúde e prevenção de doenças quando um entrevistado diz:

\begin{abstract}
"essa coisa da atenção e da prevenção é a mesma coisa...isso é uma coisa que até hoje não ficou muito certa na minha cabeça...acho que a prevenção, você já supõe que vai ter alguma coisa...e a questão da atenção, mesmo antes de você pressupor, você precisa ter cuidado... você precisa ter atenção prá nem chegar a acontecer..."
\end{abstract}

"se você previne doenças, distúrbios...você vai promover a tal da saúde..."

Mais uma vez os conceitos de prevenção e promoção de saúde são mencionados pelos entrevistados, que colocam suas dúvidas e mostram uma confusão conceitual. Os entrevistados apontam para o fato de existir a prevenção contra as doenças, mas também apontam a necessidade de uma atuação anterior à prevenção, que tanto pode estar voltada à promoção da saúde, como pode estar relacionada a uma concepção mais ampla das necessidades voltadas à qualidade e condições de vida que determinam socialmente o estado de saúde dos individuos.

Nota-se que o profissional, na falta de um ensino teórico-prático sobre saúde e formado para atuação com patologias, ainda assim consegue vislumbrar 
uma prática diferente, provavelmente intersetorial, ao tomar a prevenção como referência:

"prevenção não é isso...vồcê jogar informação...eu vejo prevenção como positiva se for prevenção mesmo...onde vai melhorar a qualidade, você não vai tar isolando a saúde..."

\subsubsection{Os Mediadores da Saúde}

No que se refere aos mediadores, novamente os entrevistados realizaram uma grande variedade de associações. Foram 37 associações. Quais subsidios serão necessários para que ocorram transformaçōes na situação de saúde de uma população? O sistema de saúde vigente, ou seja, o Sistema Único de Saúde (SUS), e o Plano de Atendimento à Saúde (PAS) foram colocados como uma forma operacional de se alcançar a saúde. Os subsídios financeiros, os remédios, as drogas, tratamentos e terapias aparecem quando se pretende alcançar a saúde eliminando-se as doenças. Para tanto é necessário que os serviços, ou seja, hospitais e médicos estejam disponiveis. As associações sugerem ainda que os aspectos voltados às condições de vida são colocados por diferentes entrevistados. São considerados mediadores da saúde a alimentação, a higiene, o saneamento, a habitação, a educação, o lazer e o carinho. No entanto a maioria das associações é colocada como condição para que ocorra a promoção da saúde e prevenção de doenças.

"você precisa de uma boa alimentação prá ter uma boa saúde...a higiene... é ela que promove uma boa saúde...uma boa habitação...pode garantir a sua saúde..."

Da forma como são colocadas, as condições para manutençāo da saúde mais parecem uma obrigação das pessoas individualmente, do que um direito que cada cidadão deveria ter.

A única associação que teve recorrência foi a educação: 
“tendo educação, a gente procura as condições de saúde...

"educação de ter freqüentado uma escola, um pouco mais intelectualizado aí... você tem uma maior possibilidade de buscar algumas coisas alternativas...batalhar pela saúde..."

"porque uma pessoa bem educada, bem formada...ela vai ter acesso a muitos cuidados, que ela sem essa possibilidade de estudo e de educação...ela deixa de ter..."

A questão social, novamente associado às condições de vida, relacionadas à inserção social, às carências e necessidades sentidas, também foi relatado como mediador para que sejam possiveis transformações na saúde dos individuos:

“...me vêm a cabeça todas as faltas de..."

"...a saúde se encontra assim, mais por um reflexo da questão social que a gente vive..."

\subsubsection{Os Qualificadores da Saúde}

Os qualificadores, 20 no total, novamente mostram-se mais negativos do que positivos nas associações para a Saúde. A recorrência no entanto, praticamente não ocorre. Pode-se analisar que os fonoaudiólogos entrevistados têm neste momento uma visão pessimista de como a saúde da população vem sendo cuidada, administrada. Apontam dessa forma uma saúde que não tem o respaldo daqueles que deveriam gerenciar o setor saúde, havendo portanto uma irresponsabilidade que tem gerado uma carência no setor. Sentem dificuldades tanto na qualidade quanto na quantidade do serviço prestado. Remetem assim a uma crise. Todas essas associações parecem estar sendo remetidas ao serviço público de saúde. As associações podem ser resumidas no seguinte trecho:

"...é a pior época que se podia pensar...eu não sei se outras pessoas estão sentindo tanto...do PAS...a gente sente pressão...condições...a gente nunca 
teve condições ideais, mas dava prá trabalhar... agora a pressão é tanta, que a gente não tem vontade de continuar os programas que a gente tem...

A FIGURA 4 sintetiza as primeiras associações dos entrevistados, buscando-se a noção nuclear do que vem a ser saúde para esses sujeitos.

Figura 4: Ocorrência da primeira associação realizada pelos entrevistados para a palavra saúde.

\begin{tabular}{|l|c|c|c||}
\hline \multicolumn{1}{|c|}{ Ocorrência } & Positivo & Negativo & Ambos \\
\hline \hline Promoção & 1 & & \\
\hline Bem-estar... & 4 & & \\
\hline PAS & & 1 & \\
\hline Prevenção & 2 & & \\
\hline Carência & 1 & 1 & \\
\hline Alegria & 1 & & \\
\hline Tristeza & 1 & & \\
\hline Mental & 1 & & \\
\hline Individual & 1 & & \\
\hline Sexo & 1 & & \\
\hline Direito & 1 & & \\
\hline Prefeitura & & & \\
\hline Ações educativas & & & \\
\hline Estudo & 1 & & \\
\hline Gostoso & & & \\
\hline \hline
\end{tabular}


A primeira associação que ocorreu com maior frequência entre os 20 entrevistados, a partir da palavra eliciadora SAÚDE, foi bem-estar (4). Além desta, a palavra prevenção foi repetida na primeira associação, e apenas por dois entrevistados.

Essas associações, e sua recorrência, sugerem que a concepção de saúde representada pelos profissionais entrevistados está voltada à uma concepção biológica, determinada por fatores multi-causais e cuja melhor forma de atuação seria o conhecimento da História Natural das Doenças e a prevençăo das mesmas nos seus diferentes estágios.

\subsection{A Palavra Eliciadora Fonoaudiologia na Atenção Primária à Saúde}

A última palavra eliciadora apresentada foi FONOAUDIOLOGIA NA ATENÇÃO PRIMÁRIA. As associaçōes feitas pelos entrevistados sugerem que não houve uma grande diversidade para essa palavra eliciadora. Pode-se perceber que a maior parte das associações refere-se aos mediadores da prática fonoaudiológica na Atenção Primária à Saúde. Se comparadas à FONOAUDIOLOGIA, é possivel analisar que os entrevistados conseguiram discursar sobre a profissão com muito maior criatividade do que sobre a ação fonoaudiológica no nivel de Atenção Primária..

A FIGURA 5 apresenta uma sintese nos permitindo visualizar as associações do conjunto dos entrevistados por categoria, sendo assinaladas conforme indicado na legenda, as frequências com que cada associação apareceu e sua valência - positiva ou negativa. 
Figura 5: Conjunto das associações categorizadas e suas respectivas freqüências positivadas e negativadas, para a palavra eliciadora FONOAUDIOLOGIA NA ATENÇÃO PRIMÁRIA.

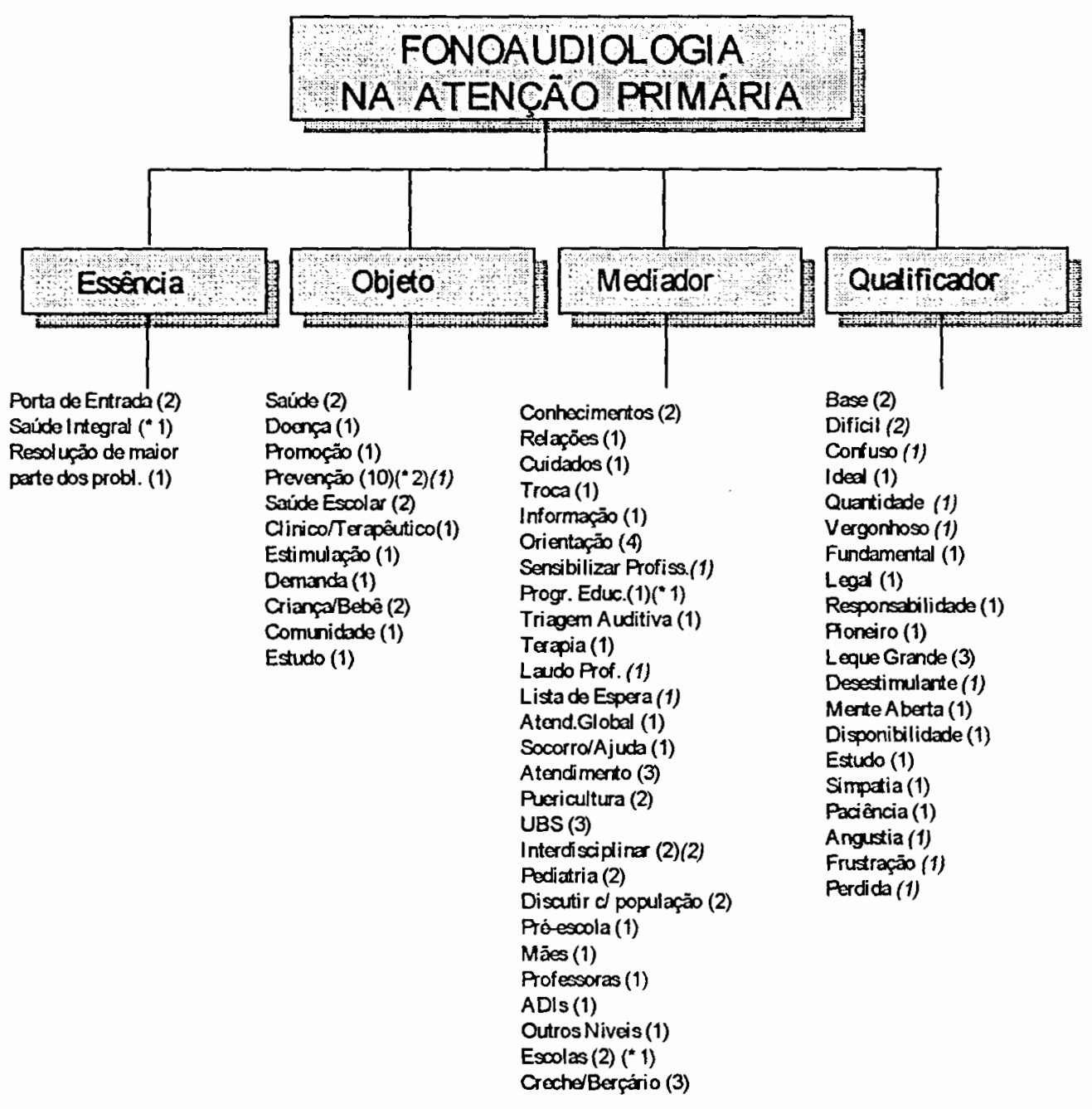

Leganda

preto- POsitivo

Dermahoitálico-NEGATIVO

ateriscoverde-POSTIVOENEGATIVO

OBS. N em par énteses referese a fr equencia coor rida da associaçăo 


\subsubsection{A Essência da Fonoaudiologia na Atenção Primária à Saúde}

Poucos entrevistados fizeram associações referentes à essência da prática fonoaudiológica no nível de Atenção Primária à Saúde. Foram apenas 4 associações no total, evidenciando que poucos entrevistados se referem à natureza desse contexto profissional. Os entrevistados associaram a prática fonoaudiológica no nivel de Atenção Primária com o termo porta de entrada, ou seja, pelo local no sistema de saúde onde os individuos iniciam seu processo de busca de resolução de suas necessidades de saúde.

\section{"é onde o sujeito chega primeiro..."}

"...eu entendo como básico no sentido do sistema de saúde...na verdade, se a coisa fosse correta, adequada...isto aqui é a entrada, fundamental, básico e porta prá todos...entra tudo por aqui..."

Além do conceito de entrada no sistema, foi feita uma única associação como o local onde grande parte dos problemas pode ser resolvida. Pode ou deveria, pois no próprio discurso o entrevistado aponta para o fato dos pressupostos serem teóricos e distantes da prática evidenciada. Ou seja, os princípios básicos da Atenção Primária nem sempre são alcançados nessas Unidades Básicas de Saúde.

\subsubsection{O objeto da Fonoaudiologia na Atenção Primária}

Há um maior número de associações, além de uma maior diversidade classificadas como o objeto da prática fonoaudiológica na Atenção Primária. Foram classificadas 26 associações para a categoria objeto, sendo que um fato nos chama a atenção: a recorrência de associações feitas para a palavra prevenção. Foi o maior número de recorrências em toda pesquisa, aparecendo em treze sujeitos, o que nos sugere que os entrevistados acreditam que o papel e objeto prioritário de trabalho do fonoaudiólogo no nivel de atenção primária seja a prevenção. O discurso nos parece coerente, se lembrarmos a concepção de 
saúde que permeia o discurso dos entrevistados para SAÚDE. A prevenção de doenças se faz necessária para que se possa alcançar bons níveis de saúde.

"eu atuo em grupos com bebês...a gente tem a vacina da BCG...o primeiro contato com a UBS...fala dàs vacinas...e também falo da minha parte...da amamentação, hábitos para os pais...e a gente tem conseguido um retorno muito bom..."

"...prevenir que coisas ocorram...eu orientando uma mãe a não usar chupeta - dia inteiro, você mostrar prá mãe como ela estimular essa criança...é...enfim...dando palestras...como eu já faço lá na região..."

"...a questão da gravidez, das gestantes... pode ser feito um trabalho...no berçário...com pessoas que têm pressão alta, diabete...onde poderiam ser trabalhados com os médicos, e a fono tá auxiliando, né?"

"bebezinhos...a gente tem um trabalho aqui na BCG...e a gente faz triagem auditiva...eu lembro dos bebês...seria legal prá diminuir a fila de espera..."

“...porque daria prá só com essa orientação, com essa...fazendo essa triagem precoce, daria prá evitar muitos e muitos casos...orientação prá familia, outros muitos...a maioria acho que daria...principalmente os atendimentos de UBS, eu acho que daria prá ser evitado...então seria o ideal...

“prevenir...eu acho que é ter uma mente aberta...se você não pensar em estar prevenindo, você não dá conta do recado..."

"se eu trabalho com as creches, se eu trabalho com as escolas...se eu trabalho com essa parte aqui em prevenção...com bebezinhos...ver chupeta, mamadeira, o que está errado...como é que se deve estimular as crianças...essas coisas assim de puericultura...é a única maneira de enxugar a demanda..."

"prevenção escolar...a nivel de orientar a professora..."

"...prevenção...porque você tem a possibilidade de fazer mais trabalhos preventivos do que...porque centros de saúde....ambulatório...hospitais...o problema já está instalado no paciente"

Um dos entrevistados chega a comentar que o trabalho preventivo, com a comunidade, dependia mais de uma vontade da chefia do que de uma política de saúde que priorizasse essa atividade: 
"...trabalho de comunidade, preventivo... participava de vários... fez um grupo lá para o pessoal de terceira idade, de costura, de crochê...ela me convidou para que eu trabalhasse junto com as mães da BCG...tentando auxiliar essas mães na maior dificuldade que elas têm...só que agora mudou a direção e ela quer produtividade..."

No entanto, nem todos os entrevistados têm clareza de como atuar preventivamente em Fonoaudiologia, apesar de ressaltarem a sua importância dentro das ações que o profissional deveria estar realizando:

"estudar também...prá saber como fazer a prevenção...juntar os fonoaudiólogos ...e estarmos vendo isso...porque a gente fala em prevenção, prevenir...mas como na área de Fonoaudiologia estar prevenindo? Como fazer a prevenção?...como estar fazendo essa prevenção nos postos?...se já vem os pacientes com problemas instalados, o que fazer também com esses pacientes...?"

"é que na atenção primária eu penso em prevenção mesmo...só que aí eu acho que é o problema...eu acho que é a questão da fono não ter ainda isso definido...então ela tenta copiar isso da saúde...da Medicina, na verdade...nem da saúde pública...eu acho que a gente tem que raciocinar de uma outra forma...diferente, quando a gente tá pensando em prevenção..."

Há ainda os que descrevem as orientações ou os trabalhos com grupos como experiências preventivas a serem avaliadas, uma vez que ocorrem de forma que parece não atingir a uma grande parte da população. Ou seja, a própria população não participa desses grupos com frequência, provavelmente sugerindo que tal ação não satisfaz suas necessidades:

"é positivo...mas nesse momento está negativo prá mim (a prevenção)...tem - grupo de orientação a usuários...aqui foi a minha experiência negativa...inscrevem-se aos montes e comparecem dois ou três..."

Parece-nos haver uma tendência a se caracterizar o trabalho fonoaudiológico no nivel de atenção primária como quase que exclusivamente preventivo. Além disso, sugere-se que o nivel de atenção primária deveria estar 
resolvendo, principalmente, os problemas mais "simples" da população,além de fazer a prevenção. Podemos analisar que os sujeitos que propõem essa organização de serviço no nível de Atenção Primária, sugerem a que as ações desenvolvidas nas Unidades Báșicas de Saúde deveriam ser "simplificadas" em termos de tipo de necessidades mostradas pelos usuários:

“...porque o primário prá mim, é quando uma coisa não está instalada... é definitivo como uma patologia, uma deficiência...um deficiente físico ou um mental, já com a coisa instalada. O primário é uma coisa do antes. No sentido de prevenir doenças, distúrbios, de esclarecer, de promover saúde...acho que tudo isso tema ver com a atenção primária...então, acho que a orientação é fundamental..."

“...prevenção...é o que deve ser feito...é o que é preconizado prá ser feito, mas não é feito, né...além de estar cumprindo o papel da atenção primária, vai estar vendo uma ação menos complexa antes que uma doença se instale..."

"entra tudo por aqui...e aqui a gente estaria fazendo um trabalho de prevenção...e tudo que é muito mais especifico ou complexo...a gente estaria mandando prá outros lugares... pro ambulatório de especialidades que não existe..."

No último discurso descrito acima, o entrevistado coloca ainda a falta de um sistema hierarquizado que prevê outros níveis de atenção integrados num mesmo sistema de saúde.

Outras duas palavras foram repetidas, porém com uma recorrência muita menor. Criança ou bebê apareceram duas vezes, ainda se referindo ao trabalho preventivo a ser desenvolvido com esta faixa etária. A idade dos individuos parece estar associada à uma trabalho preventivo mais efetivo, evitando futuras demandas especificas.

Foram classificadas as associações saúde e a saúde escolar, como objeto da prática fonoaudiológica no nível de Atenção Primária, trazendo os aspectos preventivos para esse grupo social. A saúde escolar, desde os seus primórdios, já contava com a presença de profissionais da área de distúrbios da comunicação 
com o objetivo de atuarem na prevenção e correção dos distúrbios da comunicação. Cabe relembrar, que a transferência dos profissionais da educação que atuavam com pré-escolares e escolares, para a área da saúde, ocorreu no final da década de 80 , trazendo consigo os pressupostos que fundamentavam a prática naquela área. Além disso, o excesso de demanda encaminhada aos Fonoaudiólogos e cujas necessidades são sentidas por profissionais da área da Educação, sugere uma intervenção preventivista.

"...acho que a fono da porta de entrada teria que ir até a escola...até ver por que está acontecendo (excesso de encaminhamentos) ...seria papel da UBS mesmo..."

O trabalho clínico ou terapêutico apareceu uma única vez no discurso dos profissionais entrevistados, e colocado como uma ação voltada para aqueles que não puderam se beneficiar das ações preventivas em Fonoaudiologia. 0 entrevistado coloca o papel clínico do fonoaudiólogo:

“...é justamente prá gente tratar aquilo que escapou...a gente tem condições de tratar e de oferecer pro pacientezinho, pro adulto ou prá criança...aquilo que ele precisa...a gente corrige...a gente re-educa...e ele vai continuar a vida dele feliz e segura...é isso que a gente quer...isso precisa ter ...é claro."

\subsubsection{Os Mediadores da Fonoaudiologia na At. Prim. à Saúde}

Foram classificadas 46 associações como mediadores da atuação fonoaudiológica na Atenção Primária, sugerindo que os entrevistados tinham noções variadas e talvez, reflexões sobre o que seria necessário para se desenvolver a prática fonoaudiológica nesse nível de atenção à saúde. Entretanto, não ocorreram muitas recorrências nas associações, sobressaindo-se orientação, interdisciplinar, creche, berçários e atendimento 
A orientação está voltada mais para pais e professores e tem um sentido preventivo. Para alguns entrevistados, têm ainda o efeito multiplicador já que uma orientação sobre adequação de atitudes em posturas que evitam o distúrbio podem ser retransmitidas àqueles que não participaram da orientação.

"...a orientação a gente dá mais para os pais ...a gente faz um trabalho com professores também...e você consegue tirar muita ansiedade de pai...ansiedade de professor com a orientação..."

"orientação... daria prá evitar muitos e muitos casos..."

"orientação é uma coisa básica... a gente orientar...principalmente quando você tem uma familia que já tem uma criança com problema fonoaudiológico ou outro tipo de problema na familia...dá uma orientação em relação aos outros familiares, outras crianças que tenham na familia também...prá que se estenda prá toda comunidade..."

“o trabalho na atenção primária... de orientação... grupos de ações coletivas... orientando as mães e ajudando a prevenir uma série de distúrbios..."

Alguns entrevistados mencionaram que o trabalho interdisciplinar, com grupos de orientação dentro das Unidades Básicas de saúde é mais difícil de ser realizado do que a ação desenvolvida extramuros. Ou seja, parece que esse trabalho preventivo em creches e escolas tem um impacto e facilidade maiores do que aqueles desenvolvidos dentro da própria unidade de saúde. Colocam alguns entrevistados que esse fato ocorre pela dificuldade na formação e manutenção de uma equipe interessada no desenvolvimento desse trabalho:

"a atenção primária não é o primeiro dentro da UBS...na verdade eu sinto, que quando você vai fora, e vai na creche...ai você consegue...

"isso é importante porque às vezes a gente faz fora (trabalho informativo) e esquece aqui dentro (da UBS) com outros profissionais..."

O trabalho interdisciplinar também é uma forma de se alcançar o objeto de atenção no nível primário.

"...a questão da informação... um trabalho interdisciplinar..." 
"...é difícil...não é uma coisa fácil...(o trabalho interdisciplinar) nós estávamos fazendo um grupo de aleitamento materno...ele funcionou bem no começo..."

A creche, e também a escola, como já pôde ser observado em outros trechos dos depoimentos, é um local onde os entrevistados acreditam que podem desenvolver uma atividade no nivel de Atenção Primária. Essas atividades estão sempre voltadas à orientação e não ao atendimento clínico. A satisfação tanto para com os trabalhos com grupos, como dos trabalhos com creches e escolas em alguns momentos é considerada positiva, e em outros negativa. Positiva por ser uma das formas de se alcançar a população e também de se fazer a prevenção. E negativa, pois a expectativa de outros profissionais, de pais e também do Fonoaudiólogo acaba por não ser atendida. Parece que todos ficam insatisfeitos com o resultado final.

"o trabalho da fono na atenção primária... não sei se está tão claro prá mim...mas acho que é ...creches...dependendo de como ele é feito...um programa contínuo..."

"creche e berçário...que é onde estão os pequenhinhos..."

O atendimento fonoaudiológico específicamente, foi associado por poucos profissionais. Os sujeitos entrevistados, e que fizeram tal associação, o consideram como parte das necessidades de saúde da população:

"atendimento...é uma forma de atenção à saúde..."

"o atendimento global...não só o paciente que procura, mas a família que vem..."

"eu acho que é papel também fazer o atendimento...o que eu acho é o seguinte...numa UBS acho que não seria papel da fono estar atendendo casos mais complicados...que tenham ...por falta de recursos, mesmo..." 


\subsubsection{Os Qualificadores da Fonoaudiologia na Atenção Primária}

Os qualificadores que pudemos observar nas associações realizadas pelos entrevistados sobre a" atuação fonoaudiológica no nivel de Atenção Primária totalizaram um número de 24 . No entanto, novamente a recorrência de associações foi baixa, com grande diversidade de associações. A única recorrência nas associações refere-se à diversidade possivel na atuação fonoaudiológica no nível de Atenção Primária, tendo sido colocada por dois entrevistados:

"o trabalho da fono na atenção primária...tem um leque muito grande de opções...onde ela pode atingir...onde ela pode ser útil..."

"é amplo, porque tudo o que você faz você pode estar fazendo na atenção primária..."

As associações feitas pelos entrevistados foram tanto positivadas quanto negativadas. Apesar dos entrevistados considerarem o papel da Fonoaudiologia no nivel de Atenção Primária como básico, ideal, fundamental, de responsabilidade e pioneiro, ele também foi considerado angustiante, frustrante, e de certa forma confuso e perdido. Foi considerada vergonhosa e desestimulante a quantidade de pessoas que procuram o serviço público de saúde para um atendimento.

A FIGURA 6 sintetiza as primeiras associações dos entrevistados, buscando-se a noção nuclear do que vem a ser a prática fonoaudiológica no nível de Atenção Primária à Saúde para os sujeitos entrevistados. 
Figura 6: Ocorrência da primeira associação realizada pelos entrevistados, para a palavra FONOAUDIOLOGIA.

\begin{tabular}{|l|c|c|c|}
\hline \multicolumn{1}{|c|}{ Ocorrência } & Positivo & Negativo & Ambos \\
\hline \hline Conhecimentos & 1 & & \\
\hline Porta de Entrada & 1 & & \\
\hline Creches & 1 & & \\
\hline Prevenção & 6 & & \\
\hline Informação & 1 & & \\
\hline Saúde & 1 & & \\
\hline Bebezinhos & 1 & & \\
\hline Frustração & & 1 & \\
\hline Atendimento global & 1 & & \\
\hline Grupos de & 1 & & 1 \\
\hline Orientaç. & 1 & & \\
\hline Saúde Integral & & & \\
\hline Entrosa/o cl \\
profiss.
\end{tabular}

Pode-se notar, que a primeira associação que tem maior recorrência foi prevenção. Esta é considerada como prática essencial no contexto da Atenção Primária, mesmo quando os profissionais ainda não sabem como realizá-la. 


\subsection{A Produção do Sentido na interface entre Fonoaudiologia e Prática do Cotidiano}

Conforme foi descrito no Capítulo III, esta análise será realizada a partir das temáticas centrais reveladas pela análise das representações sociais no nivel da consciência compartilhada. Ou seja, para cada palavra eliciadora, foram levantadas questões temáticas que emergiram do próprio discurso dos entrevistados e que foram analisadas. As mesmas temáticas serão utilizadas para a análise da produção do sentido na interface entre Fonoaudiologia e Fonoaudiologia na Atenção Primária, e mediada pela prática do cotidiano.

A questão que nos pareceu relevante a partir da análise da palavra eliciadora FONOAUDIOLOGIA foi o fato dos conceitos de comunicação, linguagem e fala se apresentarem de uma forma similar, o que poderia inclusive influir na prática profissional. Vejamos como podemos encontrar essa questão nas entrevistas aprofundadas dos cinco sujeitos escolhidos.

Das cinco entrevistas foi possivel notar que em apenas um caso o entrevistado declarou sempre ter pensado e atuado na Fonoaudiologia da mesma forma como atua hoje. Dois fatos influenciaram esse sujeito para que sua atuação profissional não se modificasse: o fato de ter vivenciado ser paciente em Fonoaudiologia e toda a sua formação.

Os outros entrevistados relataram ter sofrido um processo de transformação no fazer profissional. Alguns tinham uma visão assistencialista da profissão, que foi sendo modificadaa já durante o curso de graduação.. Outros consideravam o processo terapêutico tal como haviam aprendido didaticamente na universidade. A relação terapêutica foi mencionada como fator que havia se transformado. Mas todos se referem à prática clínica, principalmente a experiência nos serviços públicos, como fator fundamental no processo de transformação. 
"...eu não tinha noção...eu achava que era uma moça boazinha que ajuda gente, que tinha deficiência...minha mãe era professora e eu achava legal trabalhar com criança..."

"era aquela coisa... de você achar que vai pegar um paciente e vai ter começo, meio e fim...que você vai dar alta...e a alta era ele estar perfeito dentro do que a gente aprendeu na faculdade...estar falando com uma dicção perfeita, articulação perfeita, ter a voz perfeita...até eu trabalhar na saúde mental..."

eu comecei com comunicação...na minha cabeça era trabalhar com comunicação e com criança...(a transformação) acho que a própria experiência...a prevenção acho que foi dentro da faculdade..."

"eu acho que no começo eu tinha dificuldade de entender uma outra pessoa... dificuldade não...não era tão accessivel a outra pessoa..."

A questão central no que se refere à Saúde foi a própria concepção de saúde que os entrevistados revelaram em seus discursos. Nesse momento, estamos nos referindo ao entendimento quanto ao processo saúde/doença, à ênfase no modelo preventivista e à constatação de que o modelo teórico escolhido não se mostrava suficiente para viabilizar a saúde nos individuos. 0 modelo biológico e multicausal pode ser revelado no discurso que privilegia a prevenção e portanto, privilegia a doença e seus fatores determinantes. Mesmo quando as afirmações tentam escapar dessa concepção, a argumentação mostrase ambígua e contraditória. Analisemos então como se deu o processo de construção dessas concepções conforme o discurso observado nas cinco entrevistas mais aprofundadas:

As entrevistas aprofundadas mostraram que os entrevistados também passaram por um processo de modificação no que se refere à concepção do que vem a ser SAÚDE. Afirmam que a saúde era vista como o contrário de uma doença. Chegam a afirmar que viam como "as pessoas" vêem. O senso comum de que a saúde é o oposto da doença é uma representação importante tanto em usuários como em profissionais da saúde, e que podemos analisar nesta afirmação. 
.acho que na formação...ai entra a saúde pública...eu comecei a ter uma formação em saúde e a pensar nessas coisas...porque antes eu não tinha...era mais essa coisa de...igual as pessoas mesmo...saúde como oposição a doença..." *

As condições de vida aparecem em um discurso que procura utilizar um conceito mais abrangente da saúde. As condições adversas em vidas de usuários de unidades de saúde mostram ao profissional que a questão do bemestar pode ser vista como um conceito tão teórico, que chega a ser praticamente inatingivel.

"sabe...eu estou num momento que eu estou bem mais madura do que eu era...eu não tinha noção da vida, mesmo...fui muito preservada...então? o que eu vejo de ruim?...as pessoas aqui... sofrendo, com dor, gente pobre, que marido bebe, que apanha...então...hoje em dia, meu conceito dessa coisa de saúde é muito mais amplo...não é não estar com dor...é de viver bem, até nas relações com as pessoas...é na relação da linguagem..."

"Acho que eu via mais como doença... saúde e doença mesmo..."

O poder que o conhecimento invoca também pode ser observado nesse discurso, principalmente, após uma reflexão crítica em que se constata que o conhecimento técnico è necessário, fundamental e deve ser de excelente qualidade. No entanto, só o conhecimento técnico não é suficiente. $O$ conhecimento técnico por si só não faz com que o profissional de saúde possa atingir seus objetivos de ator (coadjuvante e não principal) em uma peça em que a população dirige o espetáculo.

"... tinha essa imagem... o profissional vai resolver tudo...nós conhecemos tudo...hoje...tem algumas coisas que eu não vou resolver nunca...(o que fez você mudar?)...a prática...as coisas que não deram certo..."

A vivência mais uma vez tem papel fundamental na transformação do saber e do fazer profissional que, após um aprendizado seguido de reflexão, vê o campo da saúde como uma área em que as ciências humanas devem estar presentes. 
"...acho que o que foi fortalecendo no desenvolver da faculdade, depois com o estágio e a vivência...foi o social...acho que sair da visão restrita saúde/doença...uma questão mais social...não só o individuo...mais coletiva, e associada às questões sociais e econômicas..."

Quanto ao papel do Fònoaudiólogo no nível de Atenção Primária, também foi possivel observar que ocorreram transformações que influenciaram na prática do cotidiano deste profissional.

Os entrevistados relatam que desconheciam totalmente o que seria o papel da Fonoaudiologia na Atenção Primária em Saúde, e a prática, mais uma vez, tem importância fundamental na construção dessa prática social. As universidades, na sua maioria, fornecem o ensino teórico e prático, mas que na versão aqui apresentada se mostrou insuficiente. A descoberta vai se dando por meio de vivência e da discussão com os pares que também experienciam a mesma situação.

"no começo eu pensava...eu só pensava no atendimento...prás questões que mais apareciam na região...não tinha muito essa idéia de prevenção e promoção separado...(a transformação)...acho que a própria noção um pouco de política de saúde, conhecer essas coisas, né...me fez mudar..."

"acho que isso a gente veio descobrindo com a prática....acho que a própria entrada na assessoria e na unidade básica são momentos que fazem uma prática associada à uma teoria..."

"não sei...acho que a prática...essas coisas eu não consigo identificar muito. Foi a prática, foi a discussão..."'

"o que eu aprendi na faculdade era aquela coisa assim... atenção primária é prevenção...o que é prevenção? é tomar vacininha contra rubéola...você orientar prá fazerem isso...você dar palestrinha...o que não dá é experiência...você vai criando..."

"eu não via (o trabalho na atenção primária) antes...eu nem sabia que tinha..."

É possivel observar nos discursos acima que os entrevistados conferem à experiência vivida na prática profissional, o fato de terem transformado conceitualmente suas concepções sobre a prática fonoaudiológica na Atenção 
Primária à Saúde. Colocam ainda, que reflexões compartilhadas com parceiros que possuem a mesma vivência também tem papel importante nesse processo de transformação.

No que se refere à argumentação com o objetivo de fazer com que um colega se candidate ao trabalho nos serviços públicos de saúde, o discurso dos entrevistados é bastante positivo, apesar de todos terem demonstrado através de expressões faiciais e hesitações na fala alguma relutância na realização dessa tarefa proposta. No seu discurso referem-se à liberdade para a construção de um fazer profissional. A experiência vivida faz com que se transformem e a partir de então criem ações que visam ter um impacto na saúde da população, mais especificamente na linguagem. Segundo os entrevistados, o trabalho nos serviços públicos de saúde permite que a criatividade apareça. Em alguns momentos a baixa remuneração, ou as políticas de saúde são apontadas como desanimadoras. Mas a construção deste trabalho, que ocorre de forma bastante diferente da atuação em clíncas ou consultórios particulares parece prevalecer, colaborando para a permanência neste contexto de atuação e ultrapassando os aspectos negativos relacionados à baixa remuneração e organização dos serviços e respectivas políticas de saúde.

"a primeira coisa seria a liberdade...porque você vai ter um leque muito grande ...com certeza alguma coisa você vai gostar lá dentro...o aspecto negativo é o salário..."

"eu acho legal ter salário...tranquiliza a gente demais...é um espaço de trabalho muito amplo...você pode criar aquele negocio..."

"venho super-animada porque um dia é diferente do outro...tem coisas que eu mudo, que eu penso diferente...aqui dá...aqui você tem um leque de situações...que eu acho que o crescimento é muito rápido..."

“...é esse lado idealista do prazer de fazer a Fonoaudiologia como a gente faz...que a gente gosta de estar envolvido e integrado...e que dá uma satisfação pessoal e profissional... e mesmo social..."

"...um lugar interessante...você tem contato com outros profissionais...você vê que tem diferenças entre comunidade e comunidade..." 
Os discursos mostram ainda que a liberdade para a contruçāo dessa prática, a experiência trocada através da comunicação e atuação conjunta com outros profissionais, além da própria constatação de sua importância enquanto profissional da saúde atuando em diferentes ações, também parece ter papel determinante para que ocorram transformações que satisfazem e motivam o Fonoaudiólogo na sua prática profissional no nível de Atenção Primária à Saúde. 
Após as análises realizadas a partir do estudo das Representações Sociais de Fonoaudiólogos que atuam em Unidades Básicas de Saúde, no nivel de Atenção Primária, sobre a prática fonoaudiológica nesse contexto, várias são as conclusões que passaremos a descrever e que podem ser refletidas na perspectiva de se buscar compreender a produção do sentido desse fazer profissional.

A primeira conclusão que podemos apontar após a análise dos dados refere-se ao fato dos entrevistados terem se mostrado satisfeitos com a escolha profissional, o que pôde ser observado pela forma como qualificam sua prática profissional. Apresentam, no entanto, uma contradição no discurso pois, sentemse desvalorizados por outros profissionais da saúde, principalmente pelos médicos. Além disso, pudemos notar que existe um descontentamento quanto aos aspectos referentes à remuneração.

Diferentes interlocutores podem ser encontrados nos discursos. 0 primeiro deles, refere-se ao Fonoaudiólogo "consciente" de sua importância enquanto profissional da saúde e da abrangência de sua atuação, enquanto profissional que atua na área da comunicação humana. O segundo interlocutor refere-se ao Fonoaudiólogo "fragilizado" pela falta de reconhecimento por outros profissionais, que não reconhecem as delimitações de seu campo de atuação e a interdisciplinariedade necessária para uma prática fonoaudiológica mais contemporânea. O terceiro interlocutor possível refere-se ao Fonoaudiólogo "desvalorizado" pela remuneração que the é atribuída no mercado de trabalho. 
Esses dados vem de encontro com a pesquisa realizada com Fonoaudiólogos por Freire, Ferreira e Coimbra (1989) que demonstrou que a carreira mostra-se atraente para aquele que a escolheu, pois somente $4 \%$ dos entrevistados pelas autoras abandonaram a profissão. A pesquisa revelou, na época, que os Fonoaudiólogos entrevistados consideravam o mercado de trabalho limitado e as ofertas encontradas tinham uma remuneração considerada aquém da desejada. Alguns Fonoaudiólgos consideravam ainda que a comunidade não mostrava a devida valorizaçāo para com a profissão.

No que se refere à natureza da prática fonoaudiológica, os Fonoaudiólogos mostraram sua atuação voltada para a comunicação, para a linguagem, para a fala e para a audição e suas manifestações, sejam elas de ordem patológica ou não. No entanto, não podemos deixar de apontar que alguns entrevistados pareciam fundir todos esses conceitos. Vejamos alguns autores que delimitam o campo de atuação do fonoaudiólogo e conceituam comunicação, linguagem e fala:

Giacominelli, Colella, Ebel e Salles (1984) descreveram o campo de atuação do fonoaudiólogo no diagnóstico, prevenção e reabilitação dos distúrbios da comunicação humana. Colocaram que esse profissional atua no diagnóstico, recuperação e prevenção de alterações relacionadas ao processo de aquisição ou desenvolvimento da linguagem. Colocaram ainda que a linguagem "é um processo que 0 individuo desenvolve durante toda a existencia, permitindo-lhe conhecer a si mesmo e ao mundo que o cerca, através do compreender, ouvir, falar, ler e escrever."

Limongi (1990) apontou como o objetivo principal do Fonoaudiólogo "o de prover os meios mais eficazes de comunicação do indivíduo com o meio em que vive, levando em consideração suas condições físicas, psicológicas, educacionais e sociais." Comentou ainda que o que se entende por comunicação são todas as formas e os aspectos que contribuem para que o indivíduo se faça entender em 
suas necessidades e desejos, assim como entender aqueles com quem convive no seu meio social. Argumentou que a comunicação é, portanto, a transmissão de experiências, idéias, conhecimentos, necessidades, sentimentos. Colocou ainda, que muito próxima ạo senso comum, a comunicação é muito relacionada com fala e linguagem. A autora definiu como linguagem "a organização e expressão do pensamento em um sistema indissoluvelmente associado com a atividade mental humana. O que caracteriza a linguagem é a sua função representativa, que será interpretada através dos processos de codificação, decodificação e recodificação." Como fala a autora definiu: "a articulação de sons, que organizados de maneiras diversas, resultarão nas palavras, sendo estas um dos componentes da tradução do pensamento."

As conceituações referentes à comunicação, linguagem e fala podem ser então sintetizadas se colocarmos que a comunicação pressupõe a troca de informações entre os individuos, onde devem estar presentes o emissor, o receptor e um código que deve ser compartilhado entre ambos. Já a linguagem, enquanto atividade simbólica, implica em uma representação que deve ser interpretada. Diversos códigos podem ser utilizados como forma de se expressar a linguagem: a oralidade, ou seja, a fala; a escrita; as diferentes forma de expressão das artes, os gestos, entre tantas outros. Não há como não relacionar os aspectos referentes à comunicação, à linguagem e à fala.

A partir da década de 80 , muitos foram os questionamentos que marcaram o pensar e o fazer fonoaudiológico. Os empréstimos de outras áreas fizeram com que os profissionais iniciassem um investimento para a construção de um saber próprio. As diferentes teorias que fundamentam hoje a prática fonoaudiológica, e que até recentemente eram emprestados à Fonoaudiologia, fazem parte de uma complexa rede que vem contribuindo para a delimitação não só do campo de atuação desse profissional tão versátil, quanto para a construção de sua própria teoria, que fundamenta suas ações. Os discursos dos entrevistados apontam inconsistências e contradições na definição de conceitos, provavelmente 
decorrentes de uma formação fragmentada no que se refere à sua fundamentação teórica.

Conforme mostrou a. literatura apresentada, o discurso do Fonoaudiólogo na área preventiva se inicia em 1982. Por um longo período os mesmos autores eram responsáveis por comunicações, pesquisas e produções literárias que apontavam a necessidade do Fonoaudiólogo se inserir no campo da Saúde Pública. Estudos epidemiológicos mostravam a prevalência dos distúrbios de audição e linguagem, que deveriam portanto ser prevenidos, identificados, diagnosticados e tratados. O modelo utilizado era o de Leavell \& Clark (1976) da História Natural das Doenças e consequentemente, pautava-se na proteção especifica contra as doenças, e nos niveis de prevenção primária, secundária e terciária.

A Fonoaudiologia, repetindo a sua própria história, se apropria dos conceitos da Medicina Preventiva e passa a utilizar este modelo para fundamentar suas ações.

Peres e Buralli (sem data) decreveram que na abordagem multi-causal há um agente, um hospedeiro e o meio-ambiente que se acham interrelacionados $e$ em constante equilibrio. Qualquer um dos fatores pode causar um desequilíbrio e, portanto, uma doença. Colocaram as autoras que a concepção mais conhecida que adota uma concepção multicausal é a História Natural das Doenças descrita por Leavell \& Clark (1976).

Andrade(1994), mostrou-nos um trabalho cientifico que adapta esse modelo para a saúde e doença fonoaudiológica. Nessa abordagem a saúdel doença é vista como um processo que é natural e pode ser iniciado mesmo antes que o homem seja afetado. Ou seja, existe o periodo de pré-patogênese onde as doenças ainda podem ser prevenidas, se conhecidas. 
Peres e Buralli (sem data) contrapõem esse modelo a um outro que tem como determinante do processo saúde/doença a qualidade de vida a que cada grupo social está exposto.

Marques (1992) coloca um conceito mais abrangente para a saúde, que "a toma como uma resultante das condições de vida e trabalho prevalecentes na nossa sociedade e do padrão de organização da base estruturada de serviços de saúde, voltados ao individuo, às coletividades e ao meio-ambiente."

É importante lembrar, ainda segundo Peres e Buralli (sem data) que, a forma como se entende o processo saúde/doença influenciará nas medidas de intervenção que se tomarão sobre ela.

No entanto, as concepções de saúde que fundamentam o modelo adotado devem ficar claras. As associações para a palavra eliciadora Saúde revelaram que o Fonoaudiólogo pensa a saúde em contraposição à doença. Vários entrevistados associaram a saúde à palavra doença e seus tratamentos. Ao pensar na doença, portanto, é necessário que possamos preveni-la. Fizeram também associações relacionadas ao conceito de saúde que indicam "o bemestar bio-psico-social'. Essas associaçōes nos levam a concluir que o modelo biológico, com a teoria multicausal da doença, é o utilizado pelos Fonoaudiólogos para fundamentarem sua prática. Os discursos mostram um Fonoaudiólogo "preventivo", fundamentado em teorias que surgem na sua formação e nas comunicações e produções cientificas. Podem ser observadas inconsistências e incoerências na tentativa de utilizarem um modelo biológico pois, o Fonoaudiólogo começa a se habituar às concepçōes de linguagem que não reduzem seus aspectos às questões orgânicas ou bio-funcionais.

Ao observarmos as associações dos Fonoaudiólogos entrevistados no que se refere à Atenção Primária à Saúde, podemos concluir novamente que estes profissionais assumiram a prevenção como o trabalho prioritário a ser desenvolvido no nivel de Atenção Primária à Saúde. Este trabalho pode ser 
traduzido a partir das representações sociais evidenciadas, e que se traduzem em uma prática voltada para a orientação em grupos à pais e no desenvolvimento de um trabalho voltado às creches e escolas. A prática preventiva também se mostrou direcionada, prioritariamente, à um determinado grupo de usuários di sistema de saúde - as crianças.

No que se refere às práticas desenvolvidas em creches e escolas, com pré-escolares e escolares, um questionamento sobre os encaminhamentos aos serviços públicos de saúde merece ser feito. Os distúrbios de linguagem que produzem esses encaminhamentos devem ser pesquisados e revisados para que não se confunda as dificuldades escolares decorrentes de questões pedagógicas com alterações de linguagem que demandam um atendimento fonoaudiológico. A busca de uma reflexão junto com os profissionais da área da Educação deveria ser o ponto de partida da prática conjunta desses profissionais e o Fonoaudiólogo.

Freire (1992) coloca que "crianças sequer alfabetizadas já sāo representadas por seus professores, como maus leitores/escritores. Nesta visão tão estreitada do processo de letramento como patologia e do distúrbio de escrita como evidência de falhas na discriminação visual e ou auditiva, ou na associação fonema-grafema, o professor coloca a origem do dito "distúrbio" para fora da escola, isentando-se portanto de sua responsabilidade enquanto educador e atribuindo exclusivamente ao Fonoaudiólogo a tarefa de "alfabetizar" essa criança."

Segundo Sucupira e Zuccolotto (1994) "ao se pensar a atenção integral à criança, não se podem definir necessidades universais, entendendo-se o escolar como uma categoria homogênea. É importante considerar sua inserção social como condição determinante de necessidades especificas. Nesta perspectiva, deve-se ter, inicialmente, o diagnóstico das características locais da população da qual essas crianças fazem parte, identificando as formas de organização social, 
condições ambientais e de moradia, acesso à educação, ao lazer e aos serviços de saúde, distribuição de renda e perfil epidemiológico."

Podemos dizer, portanto, que as ações desenvolvidas e que pretendem atingir aos escolares merecem ser repensadas e resignificadas à luz de um nova concepção de saúde que permita planejar, organizar e executar ações que venham a ter algum impacto na saúde dessas crianças, a partir de necessidades reais.

As orientações a grupos de pais visam a transmissão de conhecimentos que propiciariam um bom desenvolvimento da comunicação e de padrões da fala, e, portanto, uma prevenção quanto aos distúrbios da comunicação. No entanto, notou-se no discurso dos entrevistados uma insatisfação na realização desses grupos. A participaçāo da comunidade nessas atividades tem se mostrado baixa, o que fez com que o profissional reflitisse sua prática questionando o quanto esta ação é necessária à população.

Segundo Testa (1992) há duas maneiras pela qual pode ocorrer a participação da comunidade nos serviços de Atenção Primária. O primeiro refere-se a um "processo nascido a partir do conhecimento das necessidades sofridas e sentidas pela população, junto com a convicção de que a ação grupal pode superar os problemas que a ação individual não pode resolver." O segundo modo refere-se a uma proposta ou projeto que reflete a proposta de alguma autoridade sobre uma necessidade assinalada. No primeiro caso há a necessidade de se estar enfronhado na vivência comunitária e baseado em um requisito de intersubjetividade, que é a origem e o resultado de todo o processo. A participação torna-se assim uma questão concreta. No segundo caso, o projeto não se encontra no contexto real e a participação torna-se uma abstração e tende ao fracasso.

Os discursos dos entrevistados, que foram analisados quanto à sua prática no nivel de Atenção Primária à Saúde, nos mostram um Fonoaudiólogo 
"orientador", que busca na orientação à pais, professores e outros profissionais da área da saúde, educação e bem-estar social, uma resolução para a demanda e necessidades com relação ao atendimento fonoaudiológico. O número reduzido de Fonoaudiólogos átuando na rede pública de saúde e a carência de serviços de referência mostram um Fonoaudiólogo "escasso" e que ainda procura se adaptar à uma prática profissional em um contexto para o qual não se encontrava preparado. O Fonoaudiólogo deveria, portanto, refletir sobre sua prática nos serviços de Atenção Primária à Saúde e questionar em que medida o seu trabalho está pautado em questões técnicas ou em necessidades sentidas e descobertas a partir do reconhecimento e consequente envolvimento com as questōes sociais e com os usuários desses serviços.

A intersubjetividade já foi colocada por Testa (1992). Schraiber e MendesGonçalves (1996) afirmaram que "não basta, para sermos críticos e inovadores, alterarmos apenas o plano material das ações e das práticas em saúde. Promover a integração das ações será no máximo suficiente mas não completo. Se é necessário renovar as técnicas e seus instrumentos próprios, os recortes das necessidades de saúde, a oferta organizada para necessidades não demandadas, é preciso trabalhar direta e articuladamente a dimensão subjetiva que está presente como conformador efetivo da estruturação e dinâmica das práticas. Já referimos o necessário reconhecimento crítico da clientela dos serviços, por parte de seus profissionais. Já referimos o necessário reconhecimento critico da natureza independente e complementar dos trabalhos institucionalmente articulados em trabalho coletivo. No entanto, será imprescindivel questionar, também e sobretudo, o pressuposto da existência de técnicas e saberes definitivos. Assim como será imprescindivel, neste processo, criar espaços para a reflexão e manifestação dos usuários do serviço, para que também eles reconheçam criticamente a equipe profissional de que se valem."

Podemos ainda concluir, que o Fonoaudiólogo começa a se reconhecer como profissional da saúde. Não há incompatibilidades no seu fazer profissional em outros contextos e no nivel de Atenção Primária em Saúde. Há talvez 
prioridades diferentes. A clinica enfatiza mais a atividade terapêutica e o nivel de Atenção Primária prioriza, em alguns lugares, a ação preventiva. Tal fato pode ser observado nas entrevistas realizadas em que os profissionais associam seu campo de atuação à saúde è à prevenção. No entanto, o Fonoaudiólogo pouco comenta sobre a atenção integral à saúde.

Mendes (1993) coloca a integralidade como um dos principios de maior relevância para o sistema de saúde. Não separar as ações promocionais e preventivas das curativo-reabilitadoras "implica em reconhecer a unicidade institucional dos serviços de saúde para o conjunto das ações" que pretendem interferir no processo saúde/doença, conformando uma totalidade que engloba os sujeitos do sistema e suas inter-relaçōes com os ambientes natural e social.

As Representações Sociais que puderam ser apreendidas através da técnica de associação de idéias, buscava nessa pesquisa entender o sentido da prática fonoaudiológica nos serviços de Atenção Primária à Saúde. Após uma análise do conteúdo representacional, foi realizada uma categorização das associações realizadas, e através dela pudemos observar que os Fonoaudiólogos se referiam à natureza intrínsica da Fonoaudiologia, aqui denominada de essência; ao alvo da ação fonoaudiológica, aqui denominada de objeto; à forma como se alcança o objeto, aqui denominada de mediador; e aos investimentos afetivos, facilitadores e obstáculos da ação, aqui denominado de qualificadores. Foi possivel observar que o Fonoaudiólogo fez um maior número de associações que puderam ser classificadas como mediadores; em seguida o maior número de associações foram feitas para objeto e qualificadores; por último, poucas associaçōes foram classificadas como essência. Podemos assim concluir, que o Fonoaudiólogo ao se referir com maior frequência à forma como alcança o seu objeto, mostra uma maior proximidade com o "saber-fazer" a sua prática profissional, voltado portanto às suas habilidades especificas. Ao se referir ao alvo da ação fonoaudiológica, o Fonoaudiólogo nos mostra um "sabersaber", voltado para o conhecimento constituído pela ciência. Ao se referir à natureza da prática fonoaudiológica, o Fonoaudiólogo nos mostra um "saber-ser", 
voltado à sua essência, às suas qualidades pessoais e que remete às dimensões políticas de nossa prática social.

É por esse motivo que para finalizar, colocamos a necessidade de uma maior reflexão sobre a prática fonoaudiológica no nivel de Atenção Primária à Saúde partindo de dois aspectos importantes. A dicotomia preventivo $\mathrm{x}$ curativo deve ser superada, objetivando um atendimento integral, totalizado, e que consequentemente resultará em prestação de serviços com mais qualidade, e quem sabe um dia, mais democráticamente distribuída. Os Fonoaudiólogos devem repensar a sua prática, pautados em novas concepções de saúde, que deverão ser agregadas ao conhecimento já adquirido. O contexto da Atenção Primária à Saúde traz um desafio que se refere à inovação das práticas a serem desenvolvidas, por ser local onde as relações com outros profissionais e principalmente com os usuários do sistema de saúde ocorrem de forma diferenciada dos outros níveis de atenção.

Uma ressalva pode ser feita no que se refere à formação do profissional. A formação do Fonoaudiólogo, que vem passando por inúmeras transformações, ainda merece modificações. Apesar de todas as reformas curriculares, ainda resta a dúvida se 0 ensino tem propiciado, de forma significativa, as fundamentações teóricas que, conjuntamente com a prática supervisionada, possibilitam ao aluno vivenciar a atuação no serviço público de saúde. As Universidades devem também enfatizar a reflexão mais crítica, voltada para as demandas de ordem social que se apresentam na prática cotidiana. A fundamentação teórica, a competência técnica e a reflexão crítica possibilitarão a formação de um profissional capaz de resignificar e transformar no cotidiano uma realidade social. 
AMARAL, M. M. S. do, Fonoaudiologia em Centro de Saúde - Apreciações a Respeito de uma Experiência em São Paulo - SP. I Encontro Nacional de Fonoaudiologia, - PUC-SP, Nov. 1982, Anais, p.188-195.

ANAIS do I Encontro Nacional de Fonoaudiologia, PUC-SP, Nov. 1982.

ANAIS do VI Seminário Interdisciplinar do Centro de Estudos Fonoaudiológicos, Escola Paulista de Medicina, São Paulo, 1994.

ANDRADE, C.R.F. \& MIGLIORINI, D.R.M., Fonoaudiologia na Saúde Pública. I Encontro Nacional de Fonoaudiologia, PUC-SP, Nov. 1982, Anais p 196211.

ANDRADE, C.R.F., LINS, L, MARCHI, S.M.O.N. \& SCHOCHAT,E., Assistência Fonoaudiológica no Sistema de Saúde no Brasil, CRFa - $2^{a}$ região, mimeo enviado à Secretaria Nacional de Programas Especiais de Saúde, Ministério da Saúde, 1988.

ANDRADE, C.R.F., Fonoaudiologia e Saúde Pública, Encontro Nacional de

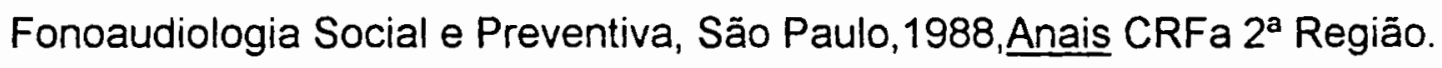

ANDRADE,C.R.F.\& SCHOCHAT,E., Perfil Audiométrico de Trabalhadores de Indústrias Ruidosas, Encontro Nacional de Fonoaudiologia Social e Preventiva, São Paulo, 1988, Anais CRFa $2^{\mathrm{a}}$ Região.

ANDRADE,C.R.F., WERTZNER,H.F.e LOPES,D.M.B., Estudo Epidemiológico das desordens da comunicação, $1^{\circ}$ Congresso Brasileiro de Epidemiologia, ABRASCO, DMPS/FCM/UNICAMP, Campinas, SP, 1990. Anais. 
ANDRADE,C.R.F., A Situação do Fonoaudiólogo no Sistema de Saúde, Lugar em Fonoaudiologia, Universidade Estácio de Sá, Julho de 1990, nº 3: 78-80.

ANDRADE,C.R.F.DE, LOPES,D.M.B. \& WERTZNER,H.F., Uma Reflexão sobre a Fonoaudiologia Preventiva, 43a Reunião Anual para o Progresso da Ciência (SBPC), Universidade Federal do Rio de Janeiro,1991, Anais Vol 43, № 7 : 152-3.

ANDRADE,C.R.F., Conceito de Saúde e Saúde Fonoaudiológica: Uma análise dos discursos dos profissionais da saúde e dos usuários dos serviços de Fonoaudiologia,São Paulo,1991 [Dissertação de Mestrado, Faculdade de Filosofia, Letras e Ciências Humanas - USP]

ANDRADE,C.R.F., LOPES, D.M.B. e Cols, Os Recursos Humanos na Fonoaudiologia Privada e Pública, II Congresso Nacional da Rede IDABrasil, 1993, Anais p.9.

ANDRADE, C.R.F., Problemas Fonoaudiológicos, In:Conceição,J.A.N., Saúde Escolar - A criança, a vida e a escola, São Paulo, Ed. Sarvier, 1994.

ANDRADE,C.R.F., Fonoaudiologia Preventiva: Discursos Científico-Pedagógico, Modelo Teórico e Vocabulário Técnico-Cientifico, São Paulo, 1994, [Tese de Doutorado- Faculdade de Filosofia, Letras e Ciências Humanas da USP],

ANDRADE, C.R.F., Fases e Niveis de Prevençãoem Fonoaudiologia - Ações Coletivas e Individuais, in VIEIRA,R.M., VIEIRA,M.M., AVILA,C.R.B.de e PEREIRA, L.D., Fonoaudiologia e Saúde Pública, Carapicuiba, Pro-Fono, 1995. 
BARRENECHEA,J.J. \& URIBE,E.T., El processo SPT/2000 y sus implicaciones para la reorientacion de la planificacion y administracion de los sistemas de servivios de salud In: Salud para todos en el año 2000 . Implicaciones para la planificación y administración de los sistemas de salud, Colombia,Ed. Univ. de Antioquia, 1987.

BEDIN, N., Saúde Coletiva e Fonoaudiologia, Encontro Nacional de Fonoaudiologia Social e Preventiva, São Paulo, 1988, Anais CRFa $2^{a}$ Região.

BEFI, D., A Formação do Fonoaudiólogo: Inserção no Sistema de Saúde, VI Seminário Interdisciplinar - CEFA: Fonoaudiologia e Saúde Pública, São Paulo, 1994. Anais.

BERBERIAN, A.P., A normatização da Língua Nacional - Práticas Fonoaudiológicas 1920-1940. São Paulo, 1993. [Dissertação de Mestrado Programa de Estudos Pós-Graduados em Distúrbios da Comunicação da PUC-SP].

BERNARDI,A.P.de A., A Experiência do Programa de Saúde dos Trabalhadores da Zona Norte - ERSA-6: Atividades em Grupo com Pacientes Expostos a Ruido, VI Seminário Interdisciplinar - CEFA: Fonoaudiologia e Saúde Püblica, São Paulo, 1994. Anais.

BEVILACQUA,M.C., LEWIS,D.R. e MORATA,T.C., Açōes Preventivas na Audição, Encontro Nacional de Fonoaudiologia Social e Preventiva, São Paulo, CRFa $2^{\mathrm{a}}$ Região, 1988. Anais.

BITAR, M.L.,Fonoaudiologia na Saúde do Escolar, Encontro Nacional de Fonoaudiologia Social e Preventiva, São Paulo, CRFa $2^{\mathrm{a}}$ Região, 1988. Anais. 
BRAGA,S.M.L., Ações Preventivas em Leitura e Escrita, Encontro Nacional de Foîoaudiologia Social e Preventiva, São Paulo, CRFa $2^{\text {a }}$ Região, 1988 Anais.

BRASIL. Leis, etc. Sobre a regulamentação da profissão de Fonoaudiólogo, lei $n^{\circ}$ 6.965 de 09 de dezembro de 1981. Profissōes Regulamentadas, Brasilia, 1982. p. 373-389.

CAMARGO, L.O.S., A Representação do Trabalho Fonoaudiológico em uma Instituição de Saúde Pública,São Paulo,1993, [Dissertação de Mestrado, Programa de Estudos Pós-Graduados em Distúrbios da Comunicação, PUC$\mathrm{SP}]$

CAPPELLETTI,I.F., Repensando a Fonoaudiologia, Encontro Nacional de Fonoaudiologia Social e Preventiva, São Paulo, CRFa $2^{\text {a }}$ Região, 1988. Anais.

\section{A Fonoaudiologia no Brasil - Reflexões sobre os seus}

Fundamentos. São Paulo, Cortez Ed., 1985.

CAVALHEIRO,M.T.P., A Universidade e os Serviços de Saúde: Currículo e Prática na Formação do Fonoaudiólogo da PucCamp, VI Seminário Interdisciplinar - CEFA: Fonoaudiologia e Saúde Pública, São Paulo, 1994. Anais.

CHIARI,B.M., Ações Preventivas na Linguagem, Encontro Nacional de Fonoaudiologia Social e Preventiva, São Paulo, CRFa $2^{\text {a }}$ Região, 1988. Anais. 
COSTA, A.R.DA, Genética e Prevenção das Alterações Fonoaudiológicas, Encontro Nacional de Fonoaudiologia Social e Preventiva, São Paulo, CRFa $2^{\mathrm{a}}$ Região, 1988. Anais.

COSTA FILHO, O.A., Aspectos Atuais da Audiologia Preventiva, Encontro Nacional de Fonoaudiologia Social e Preventiva, São Paulo, CRFa $2^{\text {a }}$ Região, 1988. Anais.

COSTA,S.A., A Universidade e os Serviços de Saúde: Currículo e Prática na Formação do Fonoaudiólogo, VI Seminário Interdisciplinar - CEFA: Fonoaudiologia e Saúde Pública, São Paulo, 1994. Anais.

CUNHA, M.C., O Normal e o Patológico em Distúrbios da Comunicação. São Paulo, 1986. [Dissertação de Mestrado - Programa de estudos pósGraduados em Distúrbios da Comunicação - PUC-SP].

CUNHA, M.C., Concepções Clínicas em Fonoaudiologia - Relação com a Medicina e Psicanálise - ou será que só é possivel filosofar em alemão? $\underline{\mathrm{R}}$. Dist. Comun., São Paulo, $\underline{3}(1), 1989$.

CYRINO, A.P.P., Organização Tecnológica do Trabalho na Reforma das Práticas e dos Serviços de Saúde: Estudo de um Serviço de Atenção Primária à Saúde, São Paulo, 1993, [Dissertação de Mestrado - Faculdade de Medicina da Universidade de São Paulo]

DE ROSA, A.S.,From Theory to Mea-theory of Social Representation: critical steps in a theoretical-methodological debate, 25th International Congress of Psychology, Brussels, 1992.

ENCONTRO Nacional de Fonoaudiologia Social e Preventiva, São Paulo, Conselho Regional de Fonoaudiologia $2^{\mathrm{a}}$ Região, 1988. 
FIGUEREDO NETO, L.E., O início da Prática Fonoaudiológica na Cidade de SãoPaulo - seus determinantes históricos e sociais. São Paulo, 1988. [Dissertação de Mestrado - Programa de Estudos Pós-Graduados em Distúrbios da Comunicação - PUC-SP].

FREIRE, R.M., FERREIRA,L.P. \& COIMBRA, L.M.V., Quem é este profissional, o fonoaudiólogo?, Rev. Dist. Comun., São Paulo, $\underline{3}(1)$ : 105-9, 1989.

, Fonoaudiologia em Saúde Pública, Rev Saúde Públ., S Paulo, 26(3): 179-84, 1992

FRIEDMAN, S. Ações preventivas na Fluência, Encontro Nacional de Fonoaudiologia Social e Preventiva, São Paulo, CRFa $2^{\text {a }}$ Região, 1988, Anais.

GÉRVAS,J.J.,PÉREZ FERNANDEZ,M.M. e GARCÍA SAGREDO,P., "Acerca de la atención primaria (forma de trabajo y características básicas) y de los registros", in GÉRVAS CAMACHO,J.J., Los Sistemas de Registro en la Atención Primaria de Salud, Madrid, Ed. Díaz de Santos S.A., 1987.

GIACOMINELLI,C., COLELLA,M.F., EBEL, S.J. \& SALLES, P.S.L.M., Fonoaudiologia e Medicina: Algumas reflexões. Med. Cult., 39(3): 133-4, 1984.

GUEDES,Z.C.F., Atenção Preventiva em Distúrbio Articulatório, Encontro Nacional de Fonoaudiologia Social e Preventiva, São Paulo, CRFa $2^{\mathrm{a}}$ Região, 1988. Anais.

GUEDES,Z.C.F., Fonoaudiologia Educacional: Ações na Escola, Anais do VI Seminário Interdisciplinar - CEFA: Fonoaudiologia e Saúde Pública, São Paulo, 1994. Anais. 
HILGERT, C.F., Perspectivas da Inserção da Fonoaudiologia no Programa Nacional de Saúde, Encontro Nacional de Fonoaudiologia Social e Preventiva, São Paulo, CRFa $2^{a}$ Região, 1988. Anais.

HARRÉ,R. , Some reflections on the concept of social representation. Social Research, 51 (4): 927-938, 1984.

IBÁÑEZ, T., Constructing a Representation os Representing a Construction? Infory \& Psychology, 4 (3): 363-381, 1994.

JACOB Fo,W., Grupo de Assistência Multidisciplinar ao Idoso Ambulatorial, Encontro Nacional de Fonoaudiologia Social e Preventiva, São Paulo, CRFa

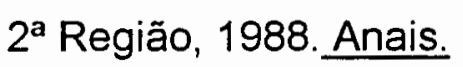

JAHODA,G., Critical notes and reflections on 'social representations'. European Journal of Social Psychology, 18: 195-209, 1988.

JODELET, D., Reflexion sur le traitment de la notion de representation sociale en psychologie sociale. Communication Information, VI(2/3):15-41, 1984.

JODELET, D., La representación social: fenomenos, concepto y teoria, In: Moscovici,S., Pensamiento y vida social, Psicologia Social y Problemas Sociales. Buenos Aires, Paidós, 1986, 469-94.

KROEGER,A. e LUNA,R., Atención Primaria de Salud- Principios y Métodos, Organización Panamericana de la Salud, Serie Paltex e Ed. Pax Mexico, 1987.

LEAVELL,H.R. e CLARK,E.G., Medicina Preventiva, São Paulo, McGraw-Hill, 1976. 
LEIRIÃO,V.H.V., A Fonoaudiologia no HPRLLP, Encontro Nacional de Fonoaudiologia Social e Preventiva, São Paulo, CRFa 2a Região, 1988. Anais.

LEWIS,D.R., A Universidade e os Serviços de Saúde: Currículo e Prática na Formação do Fonoaudiólogo, VI Seminário Interdisciplinar - CEFA: Fonoaudiologia e Saúde Pública, São Paulo, 1994. Anais.

LIMONGI, S.C.O., Reflexão Sobre o Papel do Fonoaudiólogo Como um Profissional da Área dos Distúrbios da Comunicação e Sua Atuação do Ponto de Vista da intervenção Social, Rev. Dist. Comun., São Paulo, $\underline{3}(2)$ : 157-63, 1990.

LINS,L. Fonoaudiologia na Saúde Materno-Infantil, Encontro Nacional de Fonoaudiologia Social e Preventiva, São Paulo, CRFa $2^{\text {a }}$ Região, 1988. Anais.

LINS, L. e ANDRADE, C. O Campo de Atuação do Fonoaudiólogo, in: Kudo,A.M., Fisioterapia, Fonoaudiologia e Terapia Ocupacional em Pediatria, Monografias Médicas, Série Pediatria, Volume XXXII, São Paulo - Ed. Sarvier, 1990 p. 73 a 75.

LOPES, D.M.B., Estudo das Caracteristicas do Atendimento Fonoaudiológico Realizado em Centros de Saúde da Cidade de São Paulo,São Paulo, 1991 [Dissertação de Mestrado, Programa de Estudos Pós-Graduados em Distúrbios da Comunicação, PUC-SP]

MAIA, S.M., Repensando a Fonoaudiologia ... R. Dist.Comun., São Paulo, 2 (3/4): 161-4, 1987. 
MARCONDES, E., Fatores Ambientais do Crescimento: Ênfase na Alimentação, Encontro Nacional de Fonoaudiologia Social e Preventiva, São Paulo, CRFa $2^{\mathrm{a}}$ Região, 1988. Anais.

MARSIGLIA, R.M.G., Unidades básicas de serviços de saúde: Disponibilidade tecnológica, processos de trabalho e recursos humanos, in SPINOLA,A.W.P. et al.(coord.), Pesquisa Social em Saúde, São Paulo, Cortez Editora, 1992.

MARQUES, M.B., Consideraçōes Sobre a Reforma Sanitária Brasileira Face ao Novo Paradigma tecnológico. In: Conferência Nacional de Saúde, 9a, Brasília, 1992, Anais, p.53-68.

MASSON, M.L.V., "É melhor prevenir ou remediar? Um estudo sobre a construção do conceito de prevenção em Fonoaudiologia", São Paulo, 1995, [Dissertação de Mestrado - Programa de Estudos Pós-Graduados em Distúrbios da Comunicação - PUC-SP]

MENDES, E.V., O processo social de distritalização da saúde. In: Mendes, E.V., Distrito Sanitário: O processo Social de Mudancas das prátticas Sanitárias do Sistema Único de Saúde, org., Sào Paulo - Rio, Hucitec-Abrasco, 1993. p.93-158.

MENDES,V.L.F., Fonoaudiologia nas Unidades Básicas de Saúde - A relação com os usuários, São Paulo, 1994, [Dissertação de Mestrado, Programa de Estudos Pós-Graduados em Distúrbios da Comunicação, PUC-SP]

MINAYO,M.C.S., Pesquisa Social : Teoria, método e criatividade, Petrópolis, Ed. Vozes, 1994.

MOSCOVICl,S., A Representação Social da Psicanálise, Rio de Janeiro, Zahar Ed., 1978. 
MOSCOVICI,S., Notes towards a description of Social Representations. European Journal of Social Psychology, 18: 211-250, 1988,

ORTIZ,K.Z. e BERTACHINI,L., Modelo de Atuação Fonoaudiológica em Unidades

Básicas de Saúde, VI Seminário Interdisciplinar - CEFA: Fonoaudiologia e Saúde Pública, São Paulo, 1994. Anais.

ORTIZ,K.Z., BERTACHINI,L. e PEREIRA,L.D., Atuação Fonoaudiológica em Unidades Básicas de Saúde, in VIEIRA,R.M., VIEIRA,M.M., AVILA,C.R.B.de e PEREIRA, L.D., Fonoaudiologia e Saúde Pública, Carapicuiba, Pro-Fono, 1995.

PAOLETTI,M.R.M.,BASÍLIO,C.S.,SILVA,N.S.M., CARDOSO,R.M.

e MALLET,D.H., Projeto Piloto em Saúde Pública: Relato sobre a Implantação e Desenvolvimento nas Unidades Básicas de Saúde do SUDS R-12 - São Paulo - SP, Encontro Nacional de Fonoaudiologia Social e Preventiva, São Paulo, CRFa $2^{a}$ Região, 1988. Anais.

PASETTI,A.M.M., Atuação da Fonoaudiologia na Sua Realidade Sócio-Cultural, in VIEIRA,R.M., VIEIRA,M.M., AVILA,C.R.B.de e PEREIRA, L.D., Fonoaudiologia e Saúde Pública, Carapicuiba, Pro-Fono, 1995.

PERES, F. \& BURALLI, K. O., Processo Saúde Doença, mimeo, Faculdade Saúde Pública, São Paulo, s.d.

POTTER,J. \& LITTON, J., Some problems underlying the theory of social representatios. British Journal os Social Psychology, 24: 81-90, 1985.

PREFEITURA MUNICIPAL DE SÃO PAULO, Secretaria Municipal de Educação, Histórico do Departamento de Assistência Escolar, São Paulo, 1979. 
Secretaria Municipal de Educação,

Departamento de Saúde Escolar, São Paulo, A Saúde Escolar no Contexto da educação na Cidade de São Paulo: Uma Visão Histórica, 1984a.

, Secretaria Municipal de Educação,

O Departamento de Saúde Escolar, São Paulo, 1984b.

Secretaria Municipal de

Educação, Departamento de Saúde escolar, Sua Análise Institucional de 1986 a 1988., São Paulo, 1988.

Secretaria Municipal de educação, A Saúde Escolar no Contexto da Educação na Cidade de São Paulo: Uma Visão Histórica., São Paulo, 1989.

PROENÇA,M.G.DE, Prevenção da Articulação: Uma abordagem clínica, Encontro Nacional de Fonoaudiologia Social e Preventiva, São Paulo, CRFa $2^{\text {a }}$ Região, 1988. Anais.

RAMOS, L. Fonoaudiologia e Saúde Pública, Dist. Comun., S Paulo, 4(1): 9-16, 1991.

RIVERO, D.T. de, Salud Publica y Atención Primaria de Salud: Una Evaluacion Critica in: La Crisis de la Salud Publica: Reflexiones para el debate, Organizacion Panamericana de la Salud, Publicación Científica $n^{\circ} 540$, Washington, 1992.

RIZZI,S.M., Programas de Educação para a Promoção da Saúde da Comunicação Humana, VI Seminário Interdisciplinar - CEFA: Fonoaudiologia e Saúde Pública, São Paulo, 1994. Anais. 
ROSA, A.S.de, From Theory to Meta-Theory of Soocial Representations: critical steps in a theoretical-methodological debate, 25th International Congress of Psychology, Brussels, 1992.

SAMPAIO, M.M. e Gonçalves, A., Fonoaudiologia em Saúde Pública Apreciações preliminares a propósito de experiência pioneira em São Paulo(Brasil)., Rev. Saúde Públ., São Paulo, 14:215-223, 1980.

SCHOCHAT,E., A Saúde Auditiva do Trabalhador, VI Seminário Interdisciplinar CEFA: Fonoaudiologia e Saúde Pública, São Paulo, 1994. Anais.

SCHRAIBER,L.B., Pesquisa qualitativa em saúde: reflexões metodológicas do relato oral e produção de narrativas em estudo sobre a profissão médica, Rev. Saúde Públ., São Paulo, 29(1): 63-74, 1995.

\& MENDES-GONÇALVES, R.B., Necessidades de Saúde e Atenção Primária, in: SCHRAIBER,L.B., NEMES, M.I.B. \& MENDESGONÇALVES, R.B.,(org.) Saúde do Adulto: Programas e Accões na Unidade Básica, São Paulo, Editora Hucitec, 1996.

SECRETARIA DE ESTADO DA SAÚDE DE SÃO PAULO, Proposta de Trabalho para Equipes Multiprofissionais em unidades Básicas e Ambulatórios de Saúde mental, 1983.

SEGRE,C.A.M. e CHAPCHAP,M.J., Neonatologia e Prevenção das Alterações Fonoaudiológicas, Encontro Nacional de Fonoaudiologia Social e Preventiva, São Paulo, CRFa $2^{\mathrm{a}}$ Região, 1988. Anais.

SERVILHA, E.A.M.,JESUS, M.H.F.C.,SOARES, M.T.S.N.B.,SANTOS, R.N.C.P.,RODRIGUES, T.C.L. e SANTANA,V.A.O., Fonoaudiologia em Servico", Carapicuiba, Pro-Fono, 1994. 
SIQUEIRA,A.A.F.DE, AMARAL, M.M.S.DO, OLIVEIRA,D.C.DE, BERTAGNON, J.R.D., "Problemas Fonoaudiológicos em Saúde Pública, II Congresso Paulista de Saúde Públiça e I Congresso Nacional da Abrasco, S Paulo, p:133, 1983.

SOARES,M.T.S.N.B., "Programas de Educação para a Promoção da Saúde da Comunicação Humana", Anais do VI Seminário Interdisciplinar - CEFA: Fonoaudiologia e Saúde Pública, São Paulo, 1994. Anais.

SPINK, M.J.P., As Representações Sociais e sua Aplicação em Pesquisa na Área da Saúde, Apresentado no II Congresso Brasileiro de Saúde Coletiva e III Congresso de Saúde Pública, São paulo, Julho, de 1989.

, O estudo empírico das Representações Sociais, In: Spink, M.J.P, org. O conhecimento do cotidiano, São Paulo, Ed. Brasiliense, 1993, 85-108.

\& GIMENES, M.G., Práticas Discursivas e Produção denSentido: Apontamentos Metodológicos para a Análise de Discurso Sobre a Saúde e a Doença. Saúde e Sociedade, 3/2: 149-171, 1994.

SUCUPIRA, A.C.S.L. \& ZUCCOLOTTO, S.M.C., Atenção Integral à Saúde do Escolar. In: Conceição, J.A.N., coord., Saúde Escolar - Acriança, A vida e A Escola. São Paulo, Sarvier, 1994. p.204-14.

TELLES,M.DE Q., Ações Preventivas na Voz, Encontro Nacional de Fonoaudiologia Social e Preventiva, São Paulo, CRFa $2^{\mathrm{a}}$ Região, 1988. Anais.

TESTA,M., Pensar em Saúde, Ed. Artes Médicas e Abrasco, Porto Alegre, 1992. 
VERAS,F.M.F., Atenção Primária em Saúde in ROUQUAYROL,M.Z.,



VIEIRA,R.M., VIEIRA,M.M., AVILA,C.R.B.de e PEREIRA, L.D., Fonoaudiologia e Saúde Pública, Carapicuiba, Pro-Fono, 1995.

WERTZNER,H.F., Saúde da Comunicação Oral no Pré-Escolar e Escolar, VI Seminário Interdisciplinar - CEFA: Fonoaudiologia e Saúde Pública, São Paulo, 1994. Anais.

WITTER, G.P., Implicações Sociais da Linguagem, Encontro Nacional de Fonoaudiologia Social e Preventiva, São Paulo, CRFa $2^{\mathrm{a}}$ Região, 1988. Anais. 
ANEXO 1

DIVISÃO ADMINISTRATIVA DA SECRETARIA MUNICIPAL DE SAÚDE DE SÃO PAULO

\begin{tabular}{|c|c|c|}
\hline ARS & Distrito de Saúde & Distrito Administrativo \\
\hline 1 & BELA VISTA & BELA VISTA,CAMBUCI LIBERDADE \\
\hline 1 & CONSOLAÇÃO & SANTA CECILLIA, CONSOLAÇÃO,REPÜBLICA \\
\hline 1 & SÉ & BOM RETIRO,BRÁS, PARI, SÉ \\
\hline 2 & BUTANTÄ & $\begin{array}{l}\text { BUTANTÃ,MORUMBI, RAPOSO TAVARES, RIO PEQUENO, VILA } \\
\text { SÔNIA }\end{array}$ \\
\hline 2 & LAPA & $\begin{array}{l}\text { BARRA FUNDA, JAGUARÁ, JAGUARÉ, LAPA, PERDIZES, VILA } \\
\text { LEOPOLDINA }\end{array}$ \\
\hline 2 & PINHEIROS & ALTODE PINHEIROS, ITAIM BIBI, JARDIM PAULISTA, PINHEIROS \\
\hline 3 & IPIRANGACURSINO & CURSINO, IPIRANGA, SACOMÃ \\
\hline 3 & JABAQUARA & JABAQUARA, SAÚDE, MOEMA, VILA MARIANA \\
\hline 3 & SAPOPEMBA & ARICANDUVA, SAPOPEMBA \\
\hline 3 & VILA PRUDENTE & SÃO LUCAS, VILA PRUDENTE \\
\hline 4 & MOOCA & ÁGUA RASA, BELÉM, MOOCA \\
\hline 4 & TATUAPÉ & CARRÃO, TATUAPÉ, VILA FORMOSA \\
\hline 4 & VILA MATILDE & ARTUR ALVIM, CANGAÍBA, PENHA, VILA MATILDE \\
\hline 5 & CARMOSINA & CIDADE LIDER, PARQUE DO CARMO \\
\hline 5 & GUAIANAZES & CIDADE TIRADENTES, GUAIANAZES,LAJEADO \\
\hline 5 & ITAQUERA & ITAQUERA, JOSÉ BONIFÁCIO \\
\hline 5 & SÃO MATEUS & SÃO MATEUS, SÃO RAFAEL \\
\hline 6 & ERMELINO MATARAZZO & ERMELINO MATARAZZO, PONTE RASA \\
\hline 6 & ITAIM PAULISTA & ITAIM PAULISTA, JARDIM HELENA \\
\hline 6 & SÄO MIGUEL & SÄO MIGUEL, VILA CURUÇÁ, VILA JACUÍ \\
\hline 7 & BRASILÂNDIA & BRASILÂNDIA, CACHOEIRINHA \\
\hline 7 & FREGUESIA DO O & CASA VERDE, FREGUESIA DO Ó, LIMĀO \\
\hline 7 & SANTANA & MANDAQUI, SANTANA \\
\hline 7 & TUCURUVI/JAÇANÄ & JAÇANÃ, TREMEMBÉ, TUCURUVİ, VILA MEDEIROS \\
\hline 7 & VILA MARIA & VILA GUILHERME, VILA MARIA \\
\hline 8 & PERUS & ANHANGUERA, JARAGUÁ, PERUS \\
\hline 8 & PIRITUBA & PIRITUBA, SÄO DOMINGOS \\
\hline 9 & INTERLAGOS/GRAJAÚ & CIDADE DUTRA, GRAJAÚ, SOCORRO \\
\hline 9 & PARELHEIROS & MARSILAC, PARELHEIROS \\
\hline 9 & PEDREIRAVCUPECÊ & $\begin{array}{l}\text { CAMPO BELO, CAMPO GRANDE, CIDADE ADEMAR, PEDREIRA, } \\
\text { SANTO AMARO }\end{array}$ \\
\hline 10 & CAMPO LIMPO & CAMPO LIMPO, CAPÃO REDONDO, VILA ANDRADE \\
\hline 10 & M'BOI MIRIM & JARDIM ÂNGELA, JARDIM SÃO LUIZ \\
\hline
\end{tabular}

Fonte: CEPI/SECRETARIA MUNICIPAL DE SAÚDE DE SÃO PAULO - DEZEMBRO DE 1995 ARS= ADMINISTRAÇÃO REGIONAL DE SAÚDE 
ANEXO 2

DIVISÃO ADMINISTRATIVA DA SECRETARIA ESTADUAL DA SAÚDE DE SÃO PAULO

\begin{tabular}{|c|c|}
\hline DIR & REGIÃO \\
\hline $\mathbf{I}$ & CAPITAL \\
\hline II & SANTO ANDRÉ \\
\hline III & MOGI DAS CRUZES \\
\hline IV & FRANCO DA ROCHA \\
\hline V & OSASCO \\
\hline VI & ARAÇATUBA \\
\hline VII & ARARAQUARA \\
\hline VIII & ASSIS \\
\hline IX & BARRETOS \\
\hline$x$ & BAURÚ \\
\hline $\mathbf{X I}$ & BOTUCATÚ \\
\hline XII & CAMPINAS \\
\hline$x \mid I I$ & FRANCA \\
\hline XIV & MARÍLIA \\
\hline$x V$ & PIRACICABA \\
\hline XVI & PRESIDENTE PRUDENTE \\
\hline XVII & REGISTRO \\
\hline XVIII & RIBERÃO PRETO \\
\hline$x \mid x$ & SANTOS \\
\hline$x$ & SÃO JOÃO DA BOA VISTA \\
\hline$x \times I$ & SÃO JOSÉ DOS CAMPOS \\
\hline$x \times 11$ & SÃO JOSÉ DO RIO PRETO \\
\hline$x \times 111$ & SOROCABA \\
\hline XIV & TAUBATÉ \\
\hline
\end{tabular}

Fonte: Diário Oficial do Estado de São Paulo, Vol. 105, n 91, São Paulo, 16/05/95

DIR= Direções Regionais de Saúde 


\section{ANEXO 3 \\ EXEMPLO DE ENTREVISTA PARA COLETA DE DADOS CONSCIEENCIA COMPARTILHADA E PRÁTICA DO COTIDIANO}

D- Eu queria saber a quanto tempo você se formou e aonde...

E- Em 95.

D- Então há menos de um ano?

E- Não! Imagina! Foi 85! Faz dez anos...

D- Depois de se formar você foi fazer o curso de especialização, ou você fez algum outro curso?

E- Eu fiz o curso de especialização em saúde pública o ano passado, que te dá o título de sanitarista. E agora eu tô fazendo o mestrado.

D- E você trabalha na UBS há quanto tempo?

E- Cinco anos.

D. Antes você trabalhava no serviço público?

E- Trabalhei no serviço público sim. Trabalhei na prefeitura de Mauá ... em 87.

D- Então me conta um pouquinho. Você se formou em 85 e aí o que que você foi fazer? Clínica?

E- Eu fiquei quase um ano sem trabalhar, porque eu sofri um acidente... Ai eu comecei a procurar emprego, e comecei a trabalhar com deficiência mental. Comecei a trabalhar numa instituição para deficientes mentais, e em clínica. Em uma clinica dentro de uma escola. E ai eu fui para a prefeitura de Mauá. Foi em 87. Aí em fiquei mais ou menos um ano lá. Depois eu fui prá uma escola de exepcionais também. Aí eu fui trabalhar na clinica Eli Kloger no Morumbi. Ai depois do Eli Kloger foi quando nasceu meu filho, o trabalho lá era muito puxado e eu resolvi ir pro serviço público. Eu tinha prestado um concurso, passei no concurso e resolvi assumir no estado.

D- E há cinco anos você trabalha só em UBS?

E- É! Eu trabalhei de 90 a 92 , até nascer minha outra filha, também em consultório particular. Ai depois eu não trabalhei mais em consultório particular. Desde 92 que eu não trabalho mais em consultório.

D- Então hoje é só Ubs. E há três anos é só UBS. Antes você trabalhou em vários lugares, escolas, prefeitura, clínica ...

E- E alguns pacientes que eu atendi em casa após AVC.

D. Tá! Agora, a gente vais começar a entrevista... Eu vou escrever fonoaudiologia aqui ... Eu queria que você escrevesse e fosse falando alto também, tudo que te vem à cabeça quando você vê a palavra fonoaudiologia.

E- Comunicação ... Terapia ... Prevenção ... Linguagem ... Vou falando tudo que me vem à cabeça né?

D- Isso... 
E- Paciente... Idade ... Problema ... Diagnóstico ... pera só um pouquinho ... problema ... $\begin{array}{lllllllllll}\text { diagnóstico } & \ldots & \text { queixa } & \ldots & \ldots & \text {... } & \text { encaminhamentos } & \ldots & \text { salário } & \ldots & \text { dificuldade }\end{array}$ reconhecimento ... Tá bom?

D-Se você tiver mais alguma coisa pode falar...

E- E estudo constante.

D-É isso? Comunicação, terapia, prevenção, linguagem, pacientes, idade, problema, diagnóstico, queixa, encaminhamentos, salário, dificuldade, reconhecimento e estudo constante. É isso? Então tá! De cada um deles, você acha que é um aspecto positivo ou negativo? A comunicação?

E- Positivo.

D- Por que?

E- Porque é a essência do ser humano. Eu já peguei fono por causa disso. Eu acho que você sempre busca o positivo da comunicação de cada pessoa. Eu vejo positivo.

D-E a terapia?

E- A terapia eu vejo como positivo e negativo. No objeto direto que você pode realmente intervir e ajudar. E negativo porque você também pode estigmatizar.

D- E a prevenção?

E. Positivo e negativo também. Positivo, porque se você realmente souber o que você está querendo prevenir, se você sabe realmente o que é prevenção, você sabe como agir. Negativo porque se você acha que prevenção é o ótimo, maravilhoso, vamos ai que tem que ser só prevenção, e você não souber realmente o que você quer, você vira o jogo.

D- E linguagem?

E- Linguagem ... Positivo.

D- Por que?

E- Linguagem eu vou fala mais ou menos como a comunicação. Pegar no individuo aquela linguagem que ele tem e mostrar tudo bom da linguagem que ele tem.

D- E pacientes?

E- Eu vejo como positivo.

D- Por que?

E- Primeiro pela relação. Pela inter-relação. Segundo pela minha experiência de vida, sempre foram positivos os meus relacionamentos. Eu tó me referindo eu e meu paciente. Pouquissimas vezes eu tive relaçōes ruins. Mas no geral, eu vejo como positivo esse relacionamento.

E- ldade ... Positivo e negativo

D- Me fala um pouco por que você associa fonoaudiologia e idade...

E- Me veio, me parece, logo depois que eu falei de prevenção. Eu vejo idade um pouco pelo aspecto negativo porque na hora de você chegar numa intervenção, você fala ... 
"Puxa, mas se vocè tivesse trabalhado esse individuo numa idade antes, tivesse trabalhado esse individuo", eu vejo idade mais nesse ponto, assim ... na hora me veio que as crianças chegam tarde prá mim. Na hora me veio essa idéia quando eu disse idade.

D- E ai os aspectos positivos e negativos?

E- O diagnóstico precoce e o diagnóstico tardio.

D- E problema?

E- Veio por que ... Quando eu falei em problema eu pensei assim ... Vamos dizer, se eu pego uma coisa que eu não sei ainda trabalhar. Pode ser negativo porque eu não sei ainda trabalhar, isso que eu pensei, tá ... E pode ser positivo porque se eu quiser eu vou investigar.

D- E diagnóstico?

E- Prá mim é positivo.

D- Fala um pouquinho por que?

E- Se eu conseguir fazer um bom diagnóstico de uma situação que eu tenho ali, em terapia ou prevenção, eu vou realmente saber como agir. Então, eu vejo como positivo.

D- E queixa?

E- Queixa? Prá mim é uma coisa bem particular. Eu nunca me refiro ao paciente de como é a queixa. Eu nunca pergunto como é a queixa. Então eu acho assim ... por isso até que eu citei queixa. Eu tou numa relação de terapia... Agora eu tou colocando em terapia ... estou numa relação de terapia... e senta uma pessoa lá, no caso uma mãe, se eu chegar e perguntar qual é a queixa, eu vou tar dizendo que ali eu vou estar resolvendo um problema. Não é isso que realmente que eu quero, que veja isso só um problema... que ele está com um problema. Então eu não uso a palavra queixa. Tento pegar esse diagnóstico e ver no que que eu posso auxiliar. Se ela sabe o que eu faço e no que que eu posso auxiliar.

D- Nesse sentido então vocẽ acha que é positivo ou negativo a queixa?

E- Nesse sentido, a palavra queixa eu acho negativo. Usando o termo queixa mesmo.

D- Você acha que a queixa vai criar o que? Por que você disse que nem pergunta sobre a queixa. Você dá a possibilidade do que você pode fazer.

E-Isso. Do que eu posso ajudar.

D- Então, por que você não pergunta a queixa dela?

E- Por que geralmente ela já vem com uma queixa, que alguém já disse "ah, porque ele não fala direito, porque ele não escreve direito", Então às vezes a mãe nem percebeu aquilo, e ela mesmo já carrega aquilo como uma queixa porque foi passado prá ela como uma queixa. Então eu tenho que tirar dela esse, não seria bem um estigma, mas esse papel já formado do que ela vem me falar.

D- E os encaminhamentos? Positivos ou negativos?

E- Negativo. Eu sempre... parece que ... no serviço público você vê como negativo. Prá mim essa imagem é bem negativa mesmo. Por exemplo, chega um caso de uma fissura, uma fissura palatina, um tipo de fissura que a criança tiver. E eu não tenho capacidade, nem conhecimento de atender esse caso. Não tenho vontade também de me esforçar 
nesse tipo de caso. Tá, não tenho mesmo, né? Não é uma coisa que eu goste. Mas ao mesmo tempo eu vou ter dificuldade de encaminhar esse tipo de caso, mesmo para lugares especificos que atendem, dizendo que esse trabalho qualquer fono pode fazer. E eu não vejo bem isso, tá?

\section{D- E salário?}

E- Nossa! Isso é super-negativo:' Eu que tô afastada do particular, do privado, e só estou no público, é um dilema, é um problema, até interfere no meu relacionamento pessoal, na minha familia. De eu chegar a ter essa pressão do meu marido "Por que você vai fazer mestrado em saúde pública? Por que você trabalha em saúde pública? Nós estamos precisando de dinheiro e você não vai atrás." É um problema. A ponto de eu pensar "será que não é hora de eu parar e ir atrás do dinheiro em si?"

\section{D- E dificuldade?}

E- Na hora eu pensei nisso... Em relação ao financeiro mesmo. Inclusive aparecem cursos que eu não tenho condições de fazer porque eu não tenho dinheiro. É material que eu não tenho condiçōes de comprar porque eu não tenho dinheiro. Então essa dificuldade eu pensei nisso.

D- Mais financeira, ou você pensou em outras dificuldades também?

E- Eu só pensei em financeira, viu?

D- E reconhecimento?

E- Eu também pensei em salário. Negativo ... Tudo dificuldade, salário, eu pensei em uma cadeia.

D- E estudo constante?

E- Eu gosto de estudar. Eu acho positivo, porque eu gosto de estudar. Eu não sei outras fonos. No meu caso é positivo. Acho que você tem que ter na fonoaudiologia, e acho que até um pouco mais. Porque você tem o aparato tecnológico que tá ai hoje em dia ... todo mundo sabe... mas você tem um know-how em clínica que é maior que tudo isso. É tua bagagem ... e isso é feito em cima de conhecimento... de prática também.

D- Sempre você pensou a fonoaudiologia assim?

E- Isso ai é complicado, né?

D- Você sempre achou que a fonoaudiologia era isso que te vem à cabeça ou era diferente?

E- Eu acho que o que mudou um pouco é ... ... foi o tipo de trabalho que eu realizava. Por exemplo, eu acho que... eu acho que eu tenho uma prática boa de vivência, eu acho que isso me ajudou muito. Eu acho que no começo eu tinha dificuldade de entender uma outra pessoa. Não dificuldade ... não era tão acessivel a outra pessoa. Eu trabalhava muito com deficiência mental... Então eu trabalhava muito com uma visão aqui e agora praticamente... Situação de terapia em si. Talvez tenha mudado isso. Mudei meu enfoque de trabalho. Gostava muito do trabalho que eu fazia com os PCs, com meus downszinhos, lá na clínica do Morumbi, gostava muito... Mas sentia também uma coisa assim ... ... uma certa frustração ... até de limite, né? De repente, chegava lá e parece que os pais daquela criança jogavam mais uma responsabilidade maior em cima de mim, porque eles queriam que a criança ... o que faltava prá eles, vamos ver, já conseguiu caminhar ... tudo bem ... tá andando está ótimo. Não importa que esteja flácido, hipotônico, caindo, não, não importa, mas está andando. Mas e a comunicação? Como é que fica? É você que tem que fazer isso. Então, parece que você tinha uma pressão maior e você tinha que fazer um aqui e agora realmente. Se o 
individuo falasse "papai" amanhã ... Sabe uma coisa assim ... acho que essa pressão influenciava um pouco. Agora, acho que era mais o enfoque que eu tinha antes.

D- Mas quando você entrou na Fonoaudiologia, você já achava que ia fazer isso que você faz hoje?

E- Ah! Será que eu consigo me lembrar disso?

D- Por que você optou pela Fonoaudiologia?

E- Foi uma causalidade.

D- Você escolheu ao acaso?

E- Eu nem sabia direito o que era fono. Näo sabia mesmo. E talvez eu fiquei de teimosa. Mas na época eu lembro que eu prestei outros vestibulares, todos no interior. Acho que a minha vontade era ir prá fora de casa por exemplo. E eu passei também em biomédicas... E eu fiquei muito em dúvidas, né? Então, se você me perguntar se eu fiz a escolha certa, ou se eu não fiz a escolha certa... Até hoje eu não sei dizer. Eu sei que eu fui me afundando na fono. Mas as vezes eu penso "Será que se eu tivesse feito aquilo...será que eu não taria gostando mais?..."

D- Você estudou na PUC-Campinas, e depois você veio direto trabalhar aqui?

D- Nós vamos fazer a mesma coisa com saúde. Eu vou escrever aqui no meio desse círculo, e você vai me dizer tudo que vem à sua cabeça quando você vê a palavra saúde.

E- Individual ... dificuldade ... social ... reflexo ... quantidade ... qualidade ... clinica ... prevenção .......

D- Só? Não lembra de mais nada?

D- Vamos fazer da mesma forma do outro. Você vai me falar de cada um deles, se é positivo ou negativo e por que? Então, individual...

E- Tem dois aspectos. Um positivo e um negativo. Mas pensei também no negativo porque ela é vista como individual ...

D- É mais negativa?

E- É mais negativa. Individual como assim, parece que a saúde você tem que resolver o problema da saúde independente do contexto que ele esteja. Então eu pensei nesse individual, dessa forma negativa. Sem vinculo.

D- Ele que você diz é a saúde do individuo?

E- Não. Até não a saúde individual do individuo. Eu acho que se você tiver uma saúde individual, se ele tiver os cuidados e o conhecimento, seria até positivo. Mas eu acho que a situação de saúde é colocada como individual.

D- E dificuldade?

E- Pensei nisso. Pensei bem nessa relação de isolamento da saúde, da população, do setor saúde...

D- Você acha que existe uma dificuldade? Fala um pouco mais...

E- Eu acho que a saúde é um reflexo de como vive uma população. Então você percebe trabalhando na saúde, você tem contato com profissionais que não são fonoaudiólogos mas são da saúde e ...você só vê queixa. E essa queixa acaba se transformando em 
imediatismo de você resolver queixa. Enquanto prá mim a saúde não é isso. Ela tá num contexto. E ninguém, ... não é ninguém, não consigo fechar as portas, você percebe ... que ela depende mesmo do padráo de vida que a gente tem aqui. Do que é oferecido prá nossa população. Não quer dizer que porque o indivíduo passa fome ele tem má saúde. Não é só isso. E não é uma causa tão direta. $O$ individuo passa fome e tem má saúde.

D- Então no individual, você diz que há um isolamento da saúde? É isso que você diz individual?

E- É. Mas não do indivíduo como só um individuo.

D- que ela tá isolada e que é vista como uma questão individual, onde não existem outras coisas desse contexto.

E- Isso. E ela seria um sintoma mais gritante desse contexto da população.

D- O individual é negativo, a difículdade é negativa, e o social?

E- O social e o reflexo foi tudo uma cadeia de pensamento. Também é negativo. Foi visto mais como uma coisa negativa. A saúde se encontra assim, mais por um reflexo da questão social que a gente vive. Não só pela condição de um povo, mas pela fala de condições dadas para esse coletivo. E ai tem esse reflexo na saúde.

D- E quantidade? É positivo ou negativo?

E- Engraçado. Eu vi quase tudo ai como negativo. Foi uma cadeia... Não veio mais nada na cabeça. Só as coisas mais negativas, mesmo.

D- A quantidade também?

E- Também ... Em números mesmo... em quantidade de doenças, em quantidade de consultas, em quantidade de problemas. Veio bem número mesmo.

D- E a qualidade?

E- Olha... sabe que eu pensei também em negativo. Não vai ter muita coisa positiva aí... Eu pensei negativo porque eu acho que a qualidade de vida de cada um, ela está ruim. Nem só o poder aquisitivo. Eu acho que pobreza de conhecimento, pobreza de espirito, pobreza de comunicação ... Eu acho que essa qualidade está ruim. E acho que como eu comecei falando, acho que a saúde é um sintoma gritante.

D- Então quantidade é de queixa, e qualidade é de vida?

$E \cdot \dot{E}$.

D- E a clínica?

E- A clínica, eu vi negativo porque ela veio logo depois de uma quantidade, viu... Então eu acho que a saúde se transformou em números. $E$ eu vejo isso como negativo.

D- E a clinica?

E- Eu vi ainda a clínica em relação a números, em quantidade...

D- Em quantidade de problemas a serem tratados numa clínica?

E- Isso. O número que chega, o número que vai, a quantidade em produção... e pronto... é o que importa.

D- E a prevenção? 
E- A prevenção eu vejo como negativo e como positivo. Acho que ela não muda muito do que eu pensei na fono na prevenção. Eu acho que se ... existem muitos programas ascendentes de prevenção. Vamos fazer programa de prevenção. Eu sou muito contra isso. "Vamos fazer programa de prevenção". Primeiro porque você trabalha num posto, e não desenvolve nenhum programa lá, fora a fono. Eu quando entrei, existiam programas de hipertenso, diabético, gestante ... Era tudo programa ascendente. 0 programa de hipertensão ... o médico não tinha vontade de fazer, eu acho que o médico nem tinha essa disponibilidade de ter esse conhecimento de lidar com um grupo. E só passar informação. Então é totalmente negativo prá mim. Aquilo lá não funciona. Se você dispender o mesmo tempo com o paciente falando a mesma coisa que ele falou, talvez seja melhor. Não precisa ser em grupo. Talvez possa ser direto. Prá mim a prevenção não é isso, você jogar a informação. Então as experiências que eu tive nesse tipo de programa, era quase sempre isso, um despejar de informações. Tanto que você não tinha retorno da própria população. Eu não vejo isso como prevenção. Agora eu vejo prevençáo positiva, se for visto como prevenção mesmo ... onde você vai melhorar a qualidade, você não vai tar isolando a saúde. Vocé vai estar realmente conhecendo o que que está acontecendo ali. Aquela idéia de reconhecimento não isolado. Você vai estar reconhecendo ali ... reconhecendo alguma coisa... "Vamos pesquisar". Acho que esse tipo de prevenção acho funcional, acho positivo.

D- Mais alguma coisa que você queira relacionar aqui?

E- Não ... Eu fiz na sequência, e quando parou, eu parei também.

D- Em algum momento mudou a sua visão de saúde, ou sempre foi assim?

E- Isso mudou, com certeza. Acho que mudou primeiro por causa da prática. Embora, se eu estiver em um consultório particular atendendo, o individuo, só ele, eu também estou trabalhando com a saúde desse individuo. Eu vou tentar melhorar essa qualidade de vida dele, que por algum motivo ele tem que mudar. Na faculdade, acho que na época... acho que agora é muito modismo, prevenção, tudo ...Talvez há dez anos atrás não fosse tanto... Não tivemos nada, nem uma base do que fosse lidar não só com o individual terapêuta-paciente. Não tive nenhuma outra formação, nesse sentido. Era sempre... visto bilateral ... profissional-paciente. Nunca foi passado mesmo uma visão mais global de individuo, de contexto... era sempre você tinha que ver o que estava incomodando aquele sujeito, mas diretamente, de onde ele estava. Nunca foi passado nada nesse sentido. E mudou, sim... mudou porque o trabalho na vida pública fez mudar muito.

D- O trabalho no serviço ou também na clínica?

E- No serviço.

D- Como é que você via a saúde antes?

E- Acho que eu via mais como doença. Saúde e doença mesmo.

D- Mais alguma coisa daqui?

E- Acho que não.

D. O que você imagina que seja o trabalho da fonoaudiologia na atenção primária?

E- Você sabe que isso, às vezes a gente tem reunião de posto, que a gente tem prá pegar esse assunto e discutir... Eu acho... sinto ... percebo que algumas colegas minhas sentem grande frustração com isso. Primeiro porque a gente não consegue fazer um trabalho diferenciado do que seja uma atenção primária ... ou do que seja propriamente um atendimento. Então eu acho que isso tá muito confuso e principalmente, pela 
carência de profissionais. Então você chega e fala assim... eu pretendo fazer um trabalho, mas que esse trabalho repercuta no social dessa região. Vamos tentar fazer grupo com a escola, ver o que está acontecendo, quem são nossas crianças... Aí de repente você fala também "Vamos atender"... Ai você abre uma triagem para atendimento... Olha, chega assim ... chove paciente. Eles vem em baldes... E você ao mesmo tempo fica pensando... "Bom, realmente essa familia não tem como pagar um atendimento para essa criança". Eu acho que está tudo "desvirado". Você acaba fazendo a clinica na UBS.

D- Você acha que é esse o papel da fono?

E- Não. Eu acho que isso tá acontecendo.

D- Mas na tua visão, se você pensar rapidamente, o que é o trabalho da fono na atenção primária?

E- No fundo eu acho que ela tá buscando um caminho, ela está tentando se encontrar. Eu acho que ela sabe que tem um leque muito grande de opções onde ela pode atingir... onde ela pode ser útil. Ao mesmo tempo, eu acho que essa busca de espaço reverte também na fono estar um pouco perdida. Uma vez eu acho que eu até comentei com você... Fizeram um grupo de hipertensos e gostariam que eu participasse por causa dos idosos. Eu não quis participar. Primeiro como profissional eu não saberia o que fazer com aquele grupo. Eu não tenho bagagem, conhecimento do que fazer. Não gostaria também de buscar o que eu teria que fazer ali. Foi um espaço que eu fechei. Agora isso, talvez seja negativo. Mas na minha prática, foi positivo. Teria que buscar mais um espaço de uma coisa que eu realmente não sei. Prá ir atrás de um espaço é melhor você saber o que você quer fazer. Senão é melhor não ir.

D- Deixa eu retomar, por que para mim não está claro. Qual é na tua visão o papel da fono na atenção primária? Você está colocando uma série de dificuldades. Ou então assim... Me conta um pouco do seu trabalho hoje...

E- Tá...Você quer que eu coloque a minha prática na UBS hoje?

D- Eu estou acreditando que a sua prática é o que você imagina que deva ser... Você colocou o grupo de hipertenso e porque não. Então o que você faz, você acredita que é... Prá ver o que é a fono na atenção primária...

E- Eu vou falar a minha prática, mas nem sempre o que eu faço coincide com o que eu penso de primário, tá?

D- Então você pode até me dizer o que você trabalha, o que você acha que é e o que você acha que não...

E- Tá! Na minha prática, na unidade, eu atendo paciente. Eu atendo paciente, e atendo principalmente em grupos. Eu tento aproximar sintomas e idades e atendo em grupo. Então vamos ver o que eu gosto disso e o que que eu não gosto. $O$ que que eu não gosto. Primeiro eu acho que devia ter uma atenção individualizada de terapia. Eu estou colocando em grupo prá dar quantidade. Prá dar mais chance de atendimento. Faço, mas não gosto. Tá bom. Eu to falando de terapia. Faço mas não gosto.

D- Você preferiria o atendimento individual?

E- Preferiria. Eu atendo. Eu pego por exemplo crianças que trocam surdas por sonoras. Aí eu pego três ou quatro criancinhas, e vamos trabalhar surdas/sonoras nessas crianças. Às vezes eu tenho que deslocar um grupo porque eles não se encaixaram bem. Mas ao mesmo tempo, se você tivesse um atendimento individual com a criança, talvez ela estivesse precisando disso tambẻm. Da sua atenção individual. Ela faz numa sala muito grande, depois ela no processo terapêutico já uma turma grande. Então eu faço mas eu não gosto. Faço um trabalho que agora eu estou gostando. É que nem eu 
te falei... De vez em quando aparecem projetos... Ah... vamos fazer saúde do escolar... Vocês têm que fazer saúde do escolar". Então eu falei: "Vamos lá. Vamos ver o que é saúde do escolar." Este ano, eu comecei a ir à escolas. Mas eu comecei a ir à escolas que aceitassem que eu fosse, não somente para pegar os pacientes que eles queriam que eu atendesse. Então eu fui em duas escolas, e uma, com conversas, em dois encontros que eu tive, que o que eles queriam é encaminhar o paciente. E eu não queria isso, tá? Então eu desprezei aquela escola. Teve algumas tentativas, não foi bem realizado, então eu fiquei com a escola que gostou. Então é prá fazer um trabalho com as professoras, é com as professoras... Porque elas até esqueceram de encaminhar as crianças, né. Então eu fiquei com essa escola que estava de acordo com o que eu queria realizar, com o que eu pensava. A UBS, praticamente entre aspas, teria que ser a porta de entrada. Então vamos dizer, eu estou numa região e a escola é próxima, e eu abri uma lista de triagem prá atendimento, e vieram 10 crianças da escola $x$, e é coincidente mesmo por causa da região, né... com problemas de aprendizagem, leitura/escrita e troca de surda/sonora por exemplo. Acho que a fono da porta de entrada teria que ir até a escola. Até ver porque que está acontecendo. Seria um papel de UBS mesmo. Não só ficar atendendo as crianças porque essa escola encaminhou. Então agora vou responder tua outra pergunta. Então, voltando para a escola. Então foi feito um trabalho com as professoras, de encontro... E no começo eu fui com uma proposta... Também gostei disso porque essa proposta ... Eu fiz uma proposta programada e pronta, do que eu poderia trabalhar com elas. Antes eu tive um encontro com a coordenadora, e nós discutimos bastante... Depois direto com as professoras com uma proposta pronta. Mas a vontade delas na hora era de por outros tipos de conhecimento também. Então, a programação mudava, de acordo realmente com o que elas também estavam querendo. Achei positivo. Gostei. Achei que seria realmente esse tipo de trabalho. Mas nos outros encontros que a gente foi tendo... a gente fez uma programação, né ... até porque elas dispensavam os pacientes, os alunos prá eu poder ir lá conversar com elas... Eu tinha um espaço de tempo X... Tem um compromisso com o diretor e um compromisso com os pais... E no fim desse encontro, eu pedi que elas me escrevessem, que me fizessem uma avaliação... das expectativas, se foi realmente cumprida, o que elas mais gostaram e o que elas mais gostariam... E você vê que o trabalho valeu a pena. Que elas tiveram uma outra visão, do que poderia acontecer num processo de avaliação com crianças do ciclo básico. Chegam por volta dos 7 e ficam com elas até por volta dos 8, 9 anos de idade. E elas tiraram aquela preocupação de ficar me encaminhando paciente. Então, achei isso positivo. Positivo, porque como é porta de entrada, você não abriu só a demanda. Mas você trabalhou no local onde essa demanda mais fica. O que acontece em UBS que você acaba tendo muito, é a produtividade. Conforme a direção, ela te pede a quantidade. Antes eu tinha uma diretora lá, super-legal, e que sempre estimulou trabalho de comunidade, preventivo, participava de vários, fez um grupo lá para o pessoal da terceira idade, de costura, de crochê... De tentar reverter essa renda dos trabalhos que elas fizeram... Deu resultado, enquanto ela estava lá. Ela já saiu faz uns quatro meses. Mesmo ela me convidou para que eu trabalhasse junto com as mães da BCG... Tentando auxiliar essas mães na maior dificuldade que elas têm... ou mesmo... "Eu não consigo dá de mamar porque meu peito tá rachado"... Vamos tentar encaminhar essa mãe prá uma médica, prá ver a pomada que ela pode passar, ou como a gente pode criar artifícios para que esse bico do peito melhore... Quer dizer, esse foi outro trabalho que a gente tava fazendo... Só que agora mudou a direção, e ela quer produtividade. Então, você também tá associado à tua hierarquia. Por mais que você tenha um trabalho independente, você também tem que tar associado à tua hierarquia. Por que quando eu fui prá escola, naquele tempo eu podia atender 6 pacientes. E ela chegou a me dizer que seria melhor. E eu não gostaria disso. Mas você tá vinculado à sua direção. Apesar de você não ser um profissional isolado, você tem esse vínculo da casa, do local onde você está.

D- O que mais você faz? Nós estamos seguindo uma linha do que você faz na UBS. Você tem o atendimento clínico, em grupo. Se não faz individual? 
E- Eu faço sim. Tem realmente crianças que não se encaixam no grupo, ou já tava lá um tempo esperando atendimento.

D- Então você faz um atendimento individual, em grupo, você tem um trabalho com a escola. que mais você faz?

$E-E$ a BCG. s

D- Ah, o trabalho com a BCG continua?

E- Continua.

D- Mas nem tudo o que você faz, você acha que devia ser um trabalho com atenção primária. Você foi falando um pouco no meio do caminho, o que você acha que não seria. Tem mais alguma coisa que não seria? $\bigcirc$ que você acha que não cabe na atenção primária, e o que caberia mais? O que você acha que poderia ser feito na atenção primária pelo fonoaudiólogo?

E- O que não cabe é essa quantidade de atendimento. Porque se você coloca meia hora, quarenta e cinco minutos... é um grande espaço. $E$ o número de pacientes que precisam e tão lá é muito grande. Então, eu acho que não cabe muito essa quantidade. E só não cabe porque tem poucos profissionais. Porque se tivessem mais não teria essa quantidade absurda que a gente tem na porta de posto de saúde. $\dot{E}$ assim... vergonhoso, desistimulante. Pô, tá caindo de balde paciente... O que tá acontecendo. Eu não fiz fila de espera... eu não fiz fila de espera... Eu acabei com fila de espera. Porque se eu pego uma criança com fila de espera com 7 anos, eu ainda não tenho uma previsão ainda de quando eu vou atender. E quando eu for atender ela tá com 8 e com acúmulo de dificuldades maiores. Prá mim colocar em fila de espera é paternalismo. Você segura uma família, achando que vai ter atendimento lá... Pode ser até que tenha, mas você não sabe quando, você não prevê quando. Ao mesmo tempo você tem que dar condições para essa mãe procurar em outro lugar. Ela tem que ter essa oportunidade de procurar em outros lugares. Se ela ficar comigo na lista de espera, ela poderia ter ido lá em Santana, mesmo pegando um ônibus, e talvez fosse atendida.

D- Então a lista de espera para você é negativa?

E- Eu acho. Eu terminei. Não tem lista de espera, não.

D- Continua o que você ia falar. O que é mais o atendimento da fono na atenção primária? Você falou da quantidade que é absurda, e o que mais?

E- Eu gostaria de fazer um trabalho junto com a pediatra. Sabe, eu vejo que muitas mães chegam com ... isso eu vou falar que eu gostaria, mas eu não faço, e eu acho que deveria ser trabalho de primária na UBS, mas eu não faço. Eu gostaria de trabalhar com o pediatra. Mais com o pediatra. Chega na consulta e a mãe relata a queixa, sintomática da criança. Às vezes ela vai como uma manutenção. Só que ela tem um monte de dúvidas, em relação ao que esta criança está tendo, do desenvolvimento emocional, desenvolvimento de linguagem, desenvolvimento de sociabilização... Só que ela não vai perguntar isso na consulta. Primeiro porque ela não tem tempo prá isso, e segundo porque ela sabe que não tem tempo, ela esquece todas essa perguntas que não são tão importantes. Porque no momento ele está com tosse, diarréia, o que que a gente pode fazer. Mas ao mesmo tempo a gente sabe que essa mãe queria saber como ela poderia auxiliar melhor esse filho dela. E essa consulta com o pediatra poderia favorecer isso. Mas não dá porque o tempo é curto, a quantidade é grande. Então eu queria fazer um trabalho junto com o pediatra, junto com essas mães. Uma coisa que eu acho que seria importante, mas eu não faço, tá? ... Eu acho que seria importante na UBS, que é porta de entrada, você pegar essas mães que vão na primeira consulta com o pediatra, dos quinze dias, um mês, depois no retorno do segundo mês... Mães, geralmente de primeira viagem, muitas mães jovens, muitas mães que têm muitas fluências, de palpites. E elas têm muita vontade de fazer o que elas acham, só que elas 
não sabem se é certo, e vão muitas vezes pelo palpite da vizinha que deu remédio porque tava com dor de barriga, porque o menino chorava muito. Então elas vão por experiências, que até foram boas prá vizinha, mas prá elas não é bom. Se se fizesse um trabalho mais amplo com o pediatra, porque tem informaçōes que a fono não vai poder dar. Você como pessoa, ou como mãe, você pode saber dar. Mas isso é prá você. Se você fala dá o soro. Fica coisa da vizinha, não é? Ao mesmo tempo eu sei que as mães gostariam do papel do médico presente. Eu acho até que é bom mesmo. Você tem SI que ele é o capaz de falar isso, e ao mesmo tempo você poderia dar orientações do que é esperado. O que é esperado que aconteça, não é esperado, então, é um sinal de alerta. Ou até o processo que você poderia só avisar para a mãe.

D- E o que mais?

E- Vamos ver o que mais...

D- Esse é positivo, né?

E- É positivo. Eu não faço isso. Eu não faço isso. Nem sempre você tem condições de fazer o que você acha que tem que fazer. Vamos ver... Outra coisa que eu também não faço, mas ... por isso eu acho que tá deturpado ... Na UBS você tem um espaço tão legal que você poderia usar com sua comunidade. Você poderia até sentir o que essa comunidade deseja mais. EU acho até que elas retornariam à essa UBS com mais frequência se elas sentissem que têm um apoio lá. Então, vamos dizer... se você tem uma equipe profissional, e essa equipe se dispõe ... Eu também não faço isso... se essa equipe se dispõe a fazer um trabalho fora do consultório, fora de uma consulta de pedir exame, de uma clínica, só... acho que você conseguiria bons resultados. Porque eu acredito que quase todo profissional sente, uma percepção de indivíduo mesmo, que existe uma constância de queixa, constância de problemas, e que você poderia estar tentando solucionar, trabalhar isso com sua comunidade. No caso até com a ginecologia, por exemplo. A obstetricia. Com a ginecologia, não, mas com a obstetricia, sim. Em uma mãe gestante, existem muitas expectativas. $O$ que virá a ser 0 filho dela? o que que vai acontecer, o que ela vai esperar daquela criança? A relação dela com aquela criança. Se você trabalhar ... Eu acho que a obstetra lá faz isso. Não faz um trabalho fora do consultório, da sala... Mas você sabe de muitas mães com disponibilidade de alimentar seu filho, mas não conseguem. Existem aquelas interferências que eu te falei, da vizinha, da sogra... Ou mesmo por problema fisico, a mama rachou, e ela não consegue porque a dor é insuportável. Acho que se você se dispusesse a fazer esse tipo de trabalho, a mãe entraria, e você conseguiria, com certeza produzir bons resultados. Vamos ver o que mais... Outra coisa que eu quis fazer também, e não consegui, não fiz... era tentar convidar a população a discutir mais sobre as crianças, determinada faixa de idade. Conforme a procura, eu estipularia essa faixa de idade. Eu tentei fazer... Não consegui... Com outro profissional... Que esse convite, dependeria mais do número que fosse na pediatria... Porque elas procuram a fono já com queixa. Então, eu não queria a criança com a queixa. Eu queria a criança com uma certa faixa de idade, prá você poder fazer um trabalho conjunto. Então seria interessante você fazer esse tipo de trabalho, a fono, pode ser até só a fono... eu falo só a fono porque sempre teve só eu lá, agora que tem uma psicóloga lá faz quatro meses. Claro que você precisaria de outros profissionais. A troca de experiência entre os pais eu acho bom. Ver que não é só com o filho dele que isso acontece. Ele consegue projetar uma identificação. Que aquilo também é normal. Que aquilo é esperado, que aquilo pode acontecer. Que aquilo năo, então vamos ver o que está acontecendo. Também nunca fiz isso. Nunca aconteceu esse tipo de trabalho. Outra coisa superinteressante que eu achei que ia ser super-legal, e o serviço público è super-frustrante por causa disso... Eu acho que você tem boa-vontade, só que tem um monte de impecilhos, porque só você não faz. Que nem na BCG... Vamos fazer o trabalho das BCG. Ai eu comecei a ir no grupo com todas as mães. Acho que exemplificando eu vou conseguir te responder melhor... Vamos fazer o trabalho da BCG? Vamos, ótimo, eu gosto, amamentação, eu gosto, vamos lá! É só isso que eu vou ver? Não, talvez eu veja mais coisas do próprio desenvolvimento infantil. Vamos fazer primeiro então, chegou 
uma auxiliar de enfermagem que dá a BCG. Tentamos montar um grupo. Olha onde começaram os problemas. Primeiro, a mãe foi prá vacinar a criança. Então ela tinha que esperar, porque nós vamos fazer um grupo de orientação. Essa mãe chegava a esperar mais ou menos uma hora, porque enfim, as duas, é a vacinação, mas às três é o pico, onde vão mais pessoas. Essa mãe esperar das duas às três, para você poder fazer um grupo. Primeiro problema: você tá quase que obrigando uma mãe a esperar, prá depois vacinar a criança. Prá mim isso fere o direito individual de uma pessoa que quer ir vacinar... Segundo, chegava a moça que dava a tal da vacina, colocava um quadro lá, e falava... com tal mês tem que dar essa vacina, com tal mês essa vacina, essa vacina, essa vacina, essa tem aquele efeito, aquele efeito, aquele efeito, ...mas isso é bom porque imune contra aquela e aquela doença. Quer dizer, ela falava um monte de efeito que a vacina podia dar, como elas podiam agir. Acho que a mãe até assustava. Segundo já não conseguia nem ouvir direito, porque já estava esperando há uma hora. Tem mais filho em casa, deixou com a vizinha, e tá super-preocupada e quer vacinar e ir embora. Depois vê aquele quadro assustador, das vacinas que você tem que dar prá sua filha. A BCG é a primeira, e mãe... olha, eu já vacinei dois filhos, tenho experiência pessoal de mãe, é horrivel você pegar seu filho pequenininho, de um mês e por lá para vacinar. Dói. Dói em você, e não na criança. Elas não tão nem preocupadas em querer saber aquele quadro. Já estão enfrentando um primeiro problema que é aquela vacina. Eu ficava ajudando a auxiliar a só fazer a ficha, porque eu ficava morrendo de dó, porque tava uma fila enorme prá vacina, já não tinha mais grupo, depois eu te explico ... ela vacinou dez mães, crianças... Eu tava com ela na sala. Cinco pediram prá eu segurar, porque elas tavam morrendo de dó. Acho que não é o momento prá você trabalhar ... Não é verdade? Lá a agente fez três encontros, assim. E essa moça que dá a vacina é super accessivel, conversa, ela tem uma percepção boa, do que acontece, do que é uma pessoa. Ela falou: Ah, eu não tou gostando." Eu falei:"'Ótimo, eu também não." Vamos parar? Então, vamos.Eu entrava em amamentação, e só amamentação. Eu não queria estender muito, porque elas já estavam esperando lá fazia uma hora. Queria fazer aquilo em 20 minutos, meia hora. Senão ela ia sair do posto quase três e meia, quatro. Ai eu falei prá ela: "Vamos fazer diferente?" Vacina as crianças primeiro, e convida as mães que quiserem falar com a fonoaudióloga a ir a sala ao lado. Faça um convite. Mães que quiserem ir. "Tá! Vamos tentar." Eu achei que ficou legal. É um negócio recente. Faz três meses que a gente tá fazendo, né. Então, vamos dizer, que não varia muito o número de crianças que vão vacinar à tarde. Geralmente é um número de 6 a 10. Vamos dizer que você pegue um número de 8 mães que foram vacinar aquela tarde, 5 iam falar comigo. Era uma vontade espontânea... Então, você já tirou o fator tempo dela. Ela sabe que vai conversar, e conversa você não faz em dez minutos. No minimo você faz em 7 . Então, a gente deixou a porta aberta, prá quem quisesse ir. E as que foram, eu percebi que elas tinham muita vontade de querer saber, sobre seu bebê, sobre aleitamento materno também, muitas chegaram a me perguntar porque o meu leite parou. Só que ai, tudo que eu pudesse responder com a minha visão de fono, eu respondia. Só que também, elas tinham dúvidas que eu náo podia falar. Não poderia tar auxiliando essa mãe. Eu acho que tá valendo porque a procura é espontânea. A orientação segue a vontade do que elas desejam, mas ao mesmo tempo tem um ponto negativo, que falta um complemento prá essa mãe. Por que que o filho dela está com dor de barriga? Não sou eu que vou responder porque o filho dela tem dor de barriga. É uma pergunta que um pediatra ou um outro profissional é que deveria responder. Ela sai, e algumas eu percebo que saem satisfeitas, impressão subjetiva minha. Eu percebo que algumas saem satisfeitas, mas algumas saem querendo mais. $E$ eu percebo até positivo que algumas saiam querendo mais. Porque na hora que a gente conversa, a conversa fica uma coisa mais aberta. Não fica em orientação. Quando a gente conversa e fica informal, aquelas mães que não passaram a criança no pediatra, eu tenho até que saber por que que não passaram? Ah, porque o pediatra não tem consulta, não tem hora prá mim, a agenda tá cheia. Ah, então o que que a gente pode fazer nesse caso? Eu não tento dizer que ela tem que ir no pediatra, mas eu tento ver com ela o que que ela pode fazer nesse caso. Algumas chegam prá mim e falam: Ö meu marido mandou eu pagar um pediatra particular. Eu acho que eu vou fazer isso. Só a primeira consulta, depois eu aguardo." "Tá bom." Outras falam: Äh, acho que eu vou procurar no posto perto de casa". Então, ela vai dar a resposta. Ela já sabe e só quer 
que alguém diga "faça isso mesmo". E ai eu tento mostrar prá ela que nessa consulta com o pediatra ela tem e pode explorar mais o pediatra, no sentido do desenvolvimento da criança. É isso.

D- Mais alguma coisa que você pensa da fono na atenção primária?

E-Acho que ... tá bom.

D- Você falou um monte de coisas... eu não tô fazendo isso, eu não tô fazendo isso... Por que? Você contou três situações, e a BCG, que você modificou prá uma forma que você achava mais viável. Aquelas outras que você me contou e que acha importante e não faz, não faz por que?

E- Acho que é o número mesmo. A quantidade de pacientes, não dá para fazer. Isso, porque eu acho que deveria envolver outros profissionais também. Eu acho que a fono sozinha, com gestantes, ou uma ... na neonatologia, a fono sozinha seria uma impotência muito grande. É minha visão.

D- Falta uma equipe?

E- Falta uma equipe. Essa equipe pode até ter. Mas essa equipe acaba fazendo só o atendimento. Os profissionais tão lá só para atender. Mas isso chega a mexer com toda a estrutura de saúde que a gente tem hoje. Não existem locais onde a população possa recorrer. Tem a população que não tem convênio. Até na consulta. Então, é muito grande o número de pacientes que procuram a consulta, é muito pouco o número de profissionais que dão a consulta, é uma massa de bola, sabe? É uma consulta atrás da outra. O ginecologista de manhã atende $\mathbf{4 0}$ mulheres. Tenha dó! Na trigésima, vigésima, ele já não vai ter qualidade de atendimento.

D- Você acha que as pessoas, ainda por causa da demanda, estão priorizando o atendimento clinico?

E- Eu acho. Também porque essa idéia de posto de saúde, de referência e contra referência também não funciona.

D- Antes de trabalhar no serviço público, como você via o trabalho do fonoaudiólogo na atenção primária?

E- Não via. Não via. Eu nem sabia que tinha.

D- Como é que você foi para no serviço público? Foi concurso?

E- Foi Mauá. Mas lá era diferente. Não era posto de saúde. Era um espaço muito bem equipado. Eu achei a idéia muito boa. Não sei como tá hoje. Mas era assim, era um espaço para uma equipe multiprofissional de psicólogas, fonoaudiólogas, pedagoga, assistente social, fisioterapia. Pegavam aquelas crianças que precisavam de um trabalho multiprofissional. Geralmente eram casos neurológicos, tinham casos de deficiência mental. Existiam casos de dificuldade escolar.

\section{FIM DE FITA}

D- Você queria me falar mais alguma coisa?

E- Eu queria falar assim, que eu acho que deviam existir mais convênios, com faculdades fundações, e se colocar mais profissionais dentro do posto de saúde. E eu acho que seria interessante, porque você daria mais acesso à casos que necessitam realmente de um atendimento. Prá dar acesso aquela população que precisa dar terapia pros filhos e não tem condições de um atendimento particular. Tipo estagiárias, bolsistas. Esse tipo de convênio eu acharia que seria interessante. Mas acho que isso deveria ser uma coisa muito bem pensada, porque ao mesmo tempo que existe isso, existe uma acomodação 
de não se colocar mais profissionais. Acho que isso rouba, acho que a palavra não seria bem essa... mas tira a oportunidade de mais profissionais no campo da saúde do tipo UBS. Eu vejo como positivo porque a demanda é grande, mas vejo como negativo porque a gente sabe que o estado ia realmente se acomodar, sabendo que existem essas fundações, tem essas bolsas, essas estagiárias trabalhando em posto de saúde, e não colocariam mais profissionais. Eu vejo como negativo porque você tira a oportunidade de ter mais profissionais na rede. Outra coisa que eu vejo bem negativo, se espera muito que essa fono faça um trabalho de saúde pública com uma equipe multiprofissional. Então, você está mexendo num sistema enraizado. A equipe multiprofissional só vai atuar se os profissionais estiverem dispostos para. Senão, não vai funcionar. Colocar uma estudante ou uma estagiária, onde ela não vai desenvolver um trabalho junto com o pediatra, com dentista, com a ginecologista, também acho errado. Você tá cortando a chance da tua estudante conhecer mesmo, e chegar mais próximo de uma população. Acho que é importante isso até como vivência. Segundo que eu vejo como bem negativo, as estagiárias vem, trabalham...

D- Da Universidade, ou de fundações?

E- Da Universidade. As fundações tão mais em hospitais. E principalmente da PUC. Leve isso como uma crítica. É uma crítica. Então, o que que acontece. Eu recusei na época estagiária. Não recusei. Tava grávida e ia entrar em licença, e então não quiseram que estagiária fosse lá. E eu atẻ achei bom porque eu não ia estar lá também. Que era uma condição na época da minha diretora. Ela iria abrir espaço para estagiária, se eu junto com a supervisora das estagiárias, assumisse também. E o que que acontece nos locais onde tem estagiárias. As estagiárias trabalham abril, maio e junho. Julho não trabalha porque é férias dela. Agosto, setembro, outubro. Novembro e dezembro praticamente não trabalha porque ... chega em época de fim de ano, de prova, coisa assim. Ai entra uma nova leva de estagiária, e você fica com a incerteza se vão ou não vão. Cria uma expectativa na população muito grande de que ela tenha atendimento. E a estagiária... não sei... isso é uma coisa de profissional... muitas estagiárias não assumem a responsabilidade por aquele paciente. Não faz um vinculo com o paciente. São casos que você dá uma esperança de atendimento e depois é cortado. E fica uma profissional lá, né? No caso a profissional ... a fono... "Vão atender meu filho? E agora?" Então é bem, mas ao mesmo tempo acho que isso seria mais bem estruturado.

D- Acho que esse papo depois da entrevista, a gente poderia ter um pouco maior, tá?

D- Me convença a fazer um concurso para trabalhar no serviço público...

E- A primeira coisa seria a liberdade. Faça porque você vai ter um leque muito grande. Faça, né? Eu tô lá, né, Doris! Vocē vai ter um leque muito grande de atuação. Com certeza, alguma coisa você vai gostar lá dentro. Acho dificil alguém náo gostar de alguma coisa ali dentro. Você tem liberdade prá isso. Que coisa mais legal do que você atuar com liberdade? E o aspecto negativo é o salário. Quer que eu diga que eu ganho 570 reais. Não é só o salário. É uma coisa de individuo. Você tem que trabalhar 8 horas. Você não trabalha porque ganha 570. Se você tivesse que trabalhar 8 horas por 570, você nâo trabalharia. Você cai naquele jogo que você escuta todo mundo falar. Você finge que ganha, mas você finge que trabalha. Isso é uma pouca-vergonha, como profissional, como pessoa. Isso é horrivel.

D- Mais alguma coisa?

E- Não. 


\section{EXEMPLO 2 DE ENTREVISTA PARA COLETA DE DADOS CONSCIÉNCIA COMPARTILHADA}

D- Eu queria que você olhasse a palavra Fonoaudiologia e escrevesse e falasse alto, tudo que você lembra... tudo que te vem à cabeça quando você vê a palavra Fonoaudiologia...

E- E... palavras isoladas?

D- Pode ser palavras, se você quiser falar mais também pode... mas eu queria que você me falasse tudo que te vem à cabeça...

E- Linguagem... criança... pais... brincar... falar... ouvir... ... trocar experiências ... audição... as coisas com que a gente lida ai... voz... interação..... desenvolvimento... habilidades... potencialidades... ... escrita... leitura... eu trabalho um pouco menos com isso... problemas... ah... lembrei da outra parte...

D- O que é?

E- Prevenção... os bebês... materiais... reconhecer, no sentido da pessoa reconhecer o que tem, né?... Conscientização seria melhor... eu lembro dos dentistas, dos médicos... as pessoas que estão mais com a gente aí... os professores de escola... as creches... ahn... vou chamar de equipe, quando você trabalha com outros... vou chamar de equipe multidisciplinar...

D- Mais?

E- Nossa tem bastante... (Ri)

D- Agora vamos falar de cada um deles...

E-Ih... falei demais (Ri)

D- Eu vou te perguntar sempre assim... se é positivo ou negativo... E Por que? A linguagem? É positivo ou negativo?

E-Positivo.

D- Por que?

E- Bom, é o que possibilita a comunicação. Se não tem a linguagem... o paciente lá e eu aqui... não tem interação, não tem a troca... não tem o desenvolvimento.

D- Criança...

E- Eu atendo muita criança, né? $E$ positivo também... A gente ... as crianças tem lado assim, super-bonito... um lado até mais ingênuo do que o adulto, então vem com toda a espontaneidade... se gosta, gosta... se não gosta fala... e ai que se conhece realmente a criança... a personalidade dela. Eu gosto muito... é muito positivo.

D- Pais...

E- Acho que é mais ou menos (Rí)... Pode ser?

D-Pode...

E- Os pais, justamente o que as crianças têm de espontaneidade... os pais têm muitas resistências, né?... As características ai do adulto, né?... Esconder... passam as informações pela metade... aos pouquinhos você vai conhecendo o que tem por trás daquilo... O pai que fala que não tem muito problema... não enxerga... o outro que fala 
que só tem problema, e não enxerga o lado bom da criança... E adulto em geral, a troca já é direta, em relação aos pacientes. Mas em relação às crianças... por isso que eu digo que é mais ou menos. Porque tem dificuldade de ser atingido, os pais.

D. O positivo também existe?

E-Ah... existe. Porque sem ele também o trabalho fura completamente.

D- E o brincar?

E- É... Porque quando eu lembrei da criança aqui... que é o meu maior foco... ahn... a gente usa muito o brincar com a criança. Ai que entra a linguagem, interação. Então, eu lembrei do brincar ou brinquedos. Ai eu escrevi o verbo. Mas é positivo, nesse sentido. Facilita a interação...

D- E o falar?

E- É como uma forma de expressão. A gente lida muito com isso. A Fono tem a coisa do falar bem, tentar se expressar bem, verbalmente. Então, eu lembrei do falar e do seguinte que é ouvir... Os dois lados...

D- Positivos?

E-Positivos... No sentido de tentar desenvolver. Mesmo o ouvir... os deficientes auditivos, quando a gente atende... Eu atendo menos. Não é muito minha área de tanta especialidade. Mas você procura aproveitar o pouco de audição que a pessoas tem, como uma coisa positiva, para ela poder estar recebendo e se expressar. Então aí, estão as duas coisas vinculadas...

D- Troca de experiências...

E- É aí... eu acho que é a coisa da gente aprender também com os pacientes, com os pais. Nossa... eu acho riquissimo algumas experiências que a gente tem. Ai você fica ouvindo, ouvindo... ai o pai percebe... e ele mesmo vai descobrindo a coisa... vai revelando, né? Nossa, você abre muitos caminhos, assim... até prá ter melhores atitudes com outros pais seguintes. Então, a forma de lidar... então deu certo dessa forma... Ou, não devia ter falado aquilo prá esse pai...na hora... Você vai pegando a coisa. Da próxima vez vou agir de uma forma diferente... Cobrar o pai, ou não cobrar. A própria atitude que você tem, então acho que tem essa coisa de trocar experiências que a gente aprende... Então não é só a pessoa em si, mas essa coisa de troca. É positivo.

D- Audição?

E- Audição? Ah... tá muito relacionado com ouvir ai. Acho que também é positivo.

D- A voz?

E- É... me encanta os atendimentos de voz... Porque ai mexe muito com o lado da pessoa. Você vai falar de voz, ela começa a falar de outras coisas... Dela... como ela se expressa... qual é o jeito dela, né? É super-positivo. Muito bonito.

D- E a interação?

E- Ah... eu acho que está vinculado a essa troca de experiências, né? É o que a gente procura o tempo inteiro. Porque se não tiver a interação, a coisa não acontece. Seja com os pais, adulto ou criança... É positivo.

D. Desenvolvimento... 
E- É que quando eu pensei nas crianças ai, vem a coisa de estar em fase de desenvolvimento. Seja bebês, numa área mais preventiva, né? Ou a criança já fala, já tem um distúrbio de linguagem, leitura/escrita. A gente procura lidar com esse desenvolvimento. É muito positivo. Mesmo com adulto... tá sempre em desenvolvimento... seja intelectual, afetivo...tudo, né?

D. $E$ as habilidades?

E- É que veio em seguida. Eu pensei em desenvolvimento. E você vai desenvolver o que? As habilidades das pessoas, então como positivas. Potencialidade também, que é a próxima palavra. Aqui, claro que tem o lado negativo. Às vezes a pessoa não tem habilidade prá uma coisa... Mas lidar com as duas coisas, né? Então, você não é capaz disso... Às vezes criança, que vem com muito problema, a mãe fala que não sabe, que ele só vai mal na escola, repetiu... Só vê o lado ruim, né? E a gente tentar descobrir os lados positivos. As habilidades. Então, o que você tem de potencial, e o que você não tem. Vamos lidar com as duas coisas, né?

D- A escrita e a leitura?

E- Positivo ou negativo? Também estou pensando aqui... A gente pega muito os negativos... Não escreve, não lê, não sabe nada. Na prefeitura tem um monte agora. Acho que também colocaria um mais e um menos. Que nem muito problema... e agora tá muito relacionado o lado pedagógico... Na prefeitura, por exemplo... aumentou consideravelmente os casos de crianças não alfabetizadas em terceira série por exemplo. São casos que chegam. Então, é a ausência de leitura e ausência de escrita, em crianças que já deveriam estar num nivel mais avançado. Na terceira série, porque não tem a tal da repetência... é obrigado a passar... e as escolas não tão sabendo lidar com alguns casos. Então, vem prá fono. A gente tem lidado com muitos casos de ausência de alfabetização.

D- Então, quando você lembra, você vai mais pela dificuldade que você...

E- É... atuaimente, parece que está mais pesado ...o negativo do que o positivo... a leitura e a escrita tá tão desvalorizada... a criança tão desmotivada, né? É mais o que eu vejo na rede pública. E no consultório chegam também os casos que estão com problema... a gente vai ver muitas metodologias, e tal... Mas os que mais me pegam são os casos da Prefeitura, me parece... vinculados à área pública.

D- Problema...

$E-\dot{E}$ que a gente ouve muito problema. Eu me lembrei disso... Aqueles casos complicadérrimos. Acho que no começo da minha profissão, acho até que era meio negativo. Eu me envolvia demais... Essa coisa que tive que aprender a lidar. Chorava depois de um atendimento... Ficava ali pensando... dormindo... ia prá casa e só pensava no problema da pessoa. Depois eu consegui lidar melhor com isso. Sempre tem um caso ou outro que parece que chama mais a atenção... toca um pouquinho mais...mas agora, numa fase mais ... a agente consegue ouvir e tentar lidar... Acho que é negativo...

D- Prevenção...

E- ... Prevenção... Sabe... acho que problemas têm um lado positivo. Se não fosse ele, a pessoa não vai avançar. Se está tudo bem... Isso pelo menos eu vejo mesmo comigo, no meu desenvolvimento pessoal. Quando eu tenho um problema... você tem que considerar o lado positivo dele. É a partir dele que você vai crescer também... senão Não sai do lugar. A prevenção, eu acho positivo. Muito positivo. Nossa... porque... a gente vê o resultado assim, né? Uma mãe despreparada, que nem imaginava que tinha que conversar com o bebê lá com um ano de idade. Nossa... agora que eu vejo como é importante conversar com a criança... Antes eu nem conversava com ele. Esses 
depoimentos são riquissimos, assim... de mães. Então você vê, o quanto você pode dar de dica, uma simples conversa, uma orientação... e estar prevenindo muita coisa.

D. Você pensou em prevenção e bebê?

E- Isso. Me lembrei de carregar, amamentar, os cuidados... a gente trabalha muito com bebê de risco... ne'? É positiva...

D- mesmo sendo bebê de risco é positivo?

E- Ai, tem aqueles casos mais dificeis... Mas a maioria eu tenho mais o lado positivo. Todos crescem bem, são bonitinhos... ficam muito bem. É mais positivo.

D- E os materiais?

E- Os materiais parecem que são os meios, né? Me veio muito as pessoas, o que acontece na relação... Mas você precisa dos meios prá poder lidar com a coisa.

D- E esses meios são positivos, negativos?

E- São positivos, muito positivos. Às vezes as pessoas travem esses meios. É muito rico. Reconhecer e conscientização... são as duas palavras ai... São positivos. Pode por um monte de mais aí. Muito importante, né?

D- Por que?

E- É... quando você reconhece... você pega o ponto da coisa... você resolve a questão. Em geral, é ali que você precisa chegar. Conscientização, naqueles casos de postura, musculatura oral, motricidade oral... tem muito essa coisa da conscientização... tá atento... o que que eu estou fazendo, minha boca tá aberta, minha boca tá fechada, minha respiração, né? Minha forma de falar, de me expressar... Então, você se reconhecerem e terem essa conscientização. Que é ai que você vai atingir aquilo que tá incomodando e superar. Então, super-positivo. Ai... dentistats, médicos, professores... já começam as pessoas com quem a gente lida...

D- São positivos todos?

E-Positivos todos? Não... (Ri). Dentistas... Acho que é mais ou menos também, viu. Tem uns ótimos, maravilhosos... alguns que dizem prá você o que você tem que fazer no seu trabalho... é negativo... é muito ruim... a pessoa não tem essa coisa de troca, ou de saber o que a gente faz e já vem determinando o que temos que fazer, o que não, quando temos que dar alta... Entáo tem muito o lado negativo. 0 lado positivo, a troca... principalmente essa parte de ortodontia e tal... alguns casos muito ricos. Médicos... acho que mais prá positivo. Eu tenho mais experiências positivas do que negativas.

D- $O$ que eles trazem de positivo?

E- Ahn... Eu me lembro muito dos otorrinos, que é o que eu tenho mais contato. Eles têm ajudado bastante no geral. Neurologia acho que é uma área médica um pouco mais a desejar. Quando você pede um diagnóstico mais esclarecedor, e tal... uma síndrome... esses casos mais complicados, eu acho que a neurologia jainda tá caminhando. Então, você pede uma avaliação, vem aquele retorno, aquele relatório, né? Que não esclarece muita coisa. Mas eu acho que o otorrino tá muito positivo. Tá balanceado. Tá mais prá positivo. Acho que ajudam bastante, sim.

D- E os professores? 
E- É professores... Eu diria que são muitos... são milhões na rede pública (rindo)... ahn... e eles se preocupam muito com o aluno, eu acho. Entăo quando a gente chega, e vai buscar uma troca, uma interação, um trabalho conjunto na escola e tal... eles já querem que a gente vá ver o aluno, o aluno, o aluno... então a gente sempre tem que voltar e tentar resgatar com eles. Eles sendo os estimuladores... discutir a atuação deles em sala de aula e tal... Mas é muito interessante trabalhar com professor. Acho que é mais mesmo. É positivo.

$D-E$ as escolas, creches?

E- Ai são as instituições... professores estão nas escolas... creches também têm as ADIs... as atendentes do desenvolvimento infantil...

D- Você pensou então, porque podem ser locais onde você pode estar atuando?

E. É o que a gente tem vínculo maior. Pelo menos na prefeitura, a gente tá vinculado à escola, creche... E no consultório também a gente tem muita criança, e ai você vai na escola conversar com professor... dentista também apareceu porque a gente náo vai tanto no consultório do médico ou do dentista... é mais telefone ou relatórios. Mas escolas e creches a gente vai mais. Tem mais contato direto. Conhecer a classe, a professora também quer conhecer você... Então, conhecer a instituição, é bem positivo. Acho que tem as estruturas. Cada escola, cada creche tem as suas estruturas... algumas mais fáceis de entrar e outras não... Mas são muito positivas.

D- E a equipe multidisciplinar?

E- A equipe multidisciplinar, eu acho riquíssima... Por exemplo, no consultório quando eu tó sozinha, assim... eu sinto falta das pessoas prá chegar e a gente tá trocando com outras áreas. Mesmo que o caso seja só meu, não seja do outro profissional... o psicólogo, por exemplo... trabalha aqui... a gente pode trocar experiências, discutir um caso, que é comum ou não. Mas comentar, discutir, receber uma orientação, trocar idéias ... Acho riquissimo assim... Muito mais.

D- Do mesmo jeito que nós fizemos com a Fonoaudiologia, eu queria que você fizesse com a saúde. O que te vem à cabeça quando você pensa em saúde?

E- Saúde... ... Tim-Tim... (Ri)... Saúde... Bom, me lembro da prefeitura... eu comecei a ver muito mais saúde, discutir saúde... o que que é saúde... as pessoas... ou os pacientes, seriam...as pessoas... Alguns termos eu acho que vão se repetir... Prevenção, prá gente ter essa saúde, aí. Bom, saúde também me lembra o oposto... a doença... me lembra o hospital... o lugar onde às vezes você tem que tá recorrendo prá buscar saúde... vou colocar terapias... ai ligado à... ... medicamentos... ... alimentação ... ... ai me lembro de outras coisas... higiene... eh... uma casa prá morar... eu não sei como eu chamaria isso?

D- Habitação?

E- Habitação... isso implica em saúde...saneamento... aquelas coisas ligadas à higiene, mas eu acho que tem a ver aqui... acho que educação ... ... ... me lembro de médico quando fala em saúde... todo mundo procura o médico... ... Acho que tá bom, né?

D- Tá...Prefeitura...

E- Acho positivo. Até agora... eu não sei com o Maluf (ri)... Mas abriu caminho prá promover saúde... nos últimos anos aí... Mesmo prá nossa área, na Fonoaudiologia, que não tinha... abriu tremendamente. Quantas fonos estão na saúde pública. Apesar do Maluf, eu ainda tô com uma visão positiva.

D- Mas tem o negativo? 
E- Tem... Porque dependendo da gestão que você tá, você tem mais ou menos apoio... Tem pessoas indo embora... então tem menos funcionários. Então agora, nós estamos numa fase mais prá menos do que prá mais...

$D-E$ as pessoas?

E- Acho que imaginar todo o povo bem saudável (rí). Tem que estar nas pessoas a saúde. Esse é o objetivo eu acho. As pessoas estarem bem e com saúde. É positivo.

D- A prevenção?

E- Se você previne doenças, distürbios... você vai promover a tal da saúde... Então, como positivo.

D- E a doença?

E- É me veio como oposição. Se você pega a saúde, você tem a doença. É negativo. $E$ ́́ negativo porque você tá perdendo a saúde, alguma coisa tá muito desequilibrada, né? Precisa buscar uma ajuda. A coisa não está boa.

D- E o hospital?

E- Hospital, eu acho positivo e negativo. Os particulares têm muito hospitais ótimos. Quando eu vejo a população do consultório, tem seus convênios... ótimos hospitais... uma cobertura excelente. E negativo, os hospitais da rede pública que é muito dificil. Às vezes a pessoa tem que fazer um exame demora, não tem vaga... Então, esse é o lado negativo. Deveria ter mais recursos a nivel público.

D- Terapias?

E- Terapias... porque a gente faz muita terapia (ri)... Acho que tá ligado à terapia, também tentando promover a saúde ai... buscando a saúde... É diferente do medicamento... eu coloquei em seguida... Por que eu lembrei disso. Dentro do hospital, vocé tema doença... eu comecei a fazer associação... ou você usa medicamentos dentro do hospital... a coisa mais voltada pro lado médico mesmo... e que eu acho positiva... contanto que não traga nenhuma dependência prá pessoa... mas é positiva... $E$ aí as terapias... também muito positivo.

D- Alimentação?

E- É... ai, eu já comecei a pensar o que garante a saúde. Adianta você fazer terapia e tal, ai... você volta para casa, não come bem, a criança desnutrida... Então, você precisa ter uma boa alimentação prá ter saúde. É positivo.

D- A higiene...

E- Higiene... higiene... quando é feita a higiene é positiva... quando não é feita... acho que é positivo e negativo... É ela que promove uma boa saúde... Mas quando eu penso na saúde pública... naquelas crianças carentes, que não tomam banho, que vem sujas, imundas... com piolhos... então é muito negativo...

D- Habitação...

E- ... Acho positivo... tirando as favelas também (Ri)...A gente tem uma visão... os dois lados... Então, você tem uma boa habitação, um lugar prá morar, garante, pode garantir a sua saúde. Eu acho que tá relacionado. Até a saúde mental, e não só a saúde fisica... Você tá bem fisicamente, mas você ter o seu espaço, tal...mas a saúde mental também... desde que a família seja equilibrada também...estruturada. $E$ o negativo, eu fico pensando nessas pessoas que não tem essa habitação. Então as favelas, os favelados, os pobrezinhos... Na saúde pública a gente fica vendo algumas pessoas que moram 
várias famílias no mesmo cômodo. Não é nem na mesma casa, né? Então, tem o lado negativo também.

D- E o saneamento?

E- É saneamento... também tem o lado positivo e negativo. Quando você vê determinadas categorias. Determinadas classes têm um bom saneamento, entáo tem um bom nivel de saúde, dependendo desse lado ai. E o pessoal mais carente... o saneamento zero, né? Negativo.

D- Educação?

E- Educação... Porque ai vem a coisa de pessoa ter essa ... no sentido de ter os esclarecimentos... educação de ter frequentado uma escola, um pouco mais intelectualizado aí... sem tem maior possibilidade de buscar algumas coisas, alternativas... batalhar pela... É positiva.

D- E o médico?

E. O médico parece que é uma pessoa que centraliza ... quando você pensa em saúde eu pensei... em geral a pessoa recorre quando fala em saúde, ou algum problema de saúde... vamos ao médico. É uma pessoa que pode atrair, e canalizar para alguma especialidade, ver o que precisa. Acho que o médico é fundamental. A família realmente procura o médico.

D- Então, prá ter saúde precisa ter isso aqui...

E- Não, doença é o contrário... fiz uma associação...

D- Com exceção desse alimentação, higiene, habitação, saneamento...

E- É... acho que puxou um pouco prá esse lado. Se você tem tudo isso, você pode ter uma boa saúde. Isso é um pouco da experiência que eu tenho tido na prefeitura. Quando falta a alimentação... traz o problema falta de saúde... Isso parece que tem ficado meio marcante. Falta educação... tem problema de saúde.

D- Aqui, eu queria que você me dissesse o que você acha que é o papel da fonoaudiologia no nivel de atenção primária... O que te vem à cabeça...

E- Tá... ... ... Me lembro de orientação... conhecimento... algumas palavras... criança... mas pode ser adulto também... é mais criança, mas pode ser o adulto... me lembro dos pais... me lembro das creches, berçários... me lembro dos pediatras... ... ... me vem a palavra estimulação ... ... ... me vem prevenção também... ... ... Acho que tá bom.

D- A orientação... É positivo ou negativo?

E- Positivo. É porque o primário prá mim né, é quando uma coisa não está instalada... é definitivo, como uma patologia, uma deficiência... um deficiente físico ou um deficiente mental, já com uma coisa instalada. O primário é uma coisa do antes, né? No sentido então de prevenir doenças, distúrbios, de esclarecer, de promover a saúde. Acho que tudo isso tem a ver com a atençăo primária. Então, acho que a orientação é fundamental. Conhecimento... também é positivo.

D- O que é esse conhecimento?

E- Me veio também da orientação. Porque quando a gente tá orientando uma familia, um paciente... mesmo dentro de uma creche orientando os profissionais que trabalham com crianças... isso tem a ver com atenção primária. $E$ aí.. a gente promove um conhecimento... Bom, eu aprendo demais do desenvolvimento das crianças... A creche por exemplo... as ADls falam, e eu vou lá e observo as crianças. Vejo como é esse 
grupinho... vou lá no outro de outra idade... Então, conhecer... é conhecer, conhecer, conhecer. Conhecimento meu, e também da pessoa com quem eu tô. Seja o próprio paciente que vai se conhecendo, a professora, Adi da creche. Tem até a coisa de conhecer a teoria das coisas... o que se diz... o que os autores falam... e na prática o que que acontece e tal.

D- E a criança?

E- Aí eu coloquei as pessoas, né? A criança, o adulto... e os pais. Bom a criança e adulto em si, como se fosse uma pessoa que a gente pudesse dar essa atenção primária. A Fono dando uma atenção primária, prá criança e adulto, né? A criança porque está em fase de desenvolvimento. Ë justamente a fase importante de você prevenir problemas...

D- Que tipo de trabalho você faria com adultos, com crianças, com os pais...?

E- Com criança, se você pegar pequena, em desenvolvimento... mesmo bebê... e... você... estar conhecendo em que nivel que está essa criança... se ela está bem ou não... e detectar alguma coisa... e orientar... aí que entram os pais... Porque às vezes você não atua direto com a criança, mas você atua com os pais, que é o canal, que é quem cuida da criança... que tá em casa... que vai estimular e tal... $O$ adulto... porque o adulto às vezes já vem com o problema... Muitas vezes você dando alguma dica ou comentando ... principalmente em casos de voz, até mesmo com professores... acho que esse é o lado ... um exemplo de uma atenção primária... Você está conversando sobre crianças e começa a falar da atitude da professora e tal...como você usa a sua voz... e aí a gente trocando isso ela pode tomar mais cuidado com isso e evitar um futuro nódulo nas cordas vocais, e um problema de voz... Então eu acho que é atenção primária também.

D- Creche e berçário...

E- Aí... eu me lembrei do local... né? A instituição em si, muito positivo...

D- Então, a Fono na atenção primária, também estaria dando uma atenção às creches $\mathrm{e}$ berçários?

E- Sim... Que é onde estão os pequeninos...

D- Mas eles vão ao posto...

E- Também vão... é verdade...

D- E a creche e o berçário?

E- É... Engraçado que no posto... na UBS... é ... a gente pega criança... mas em menos porcentagem... as crianças menores. A grande concentração é na faixa escolar de 5 a 9 anos. É a grande massa. E já vem com problemas. A UBS me parece mais não é ... a atenção primária não é o primeiro dentro da UBS. Na verdade eu sinto, que quando você vai fora, e vai na creche... ai você consegue...

D- Então é mais fácil fazer um trabalho de nivel de atenção primária em ações extra-muros do que no posto?

E- É... na própria unidade, a gente tem o vínculo... pelo menos eu tenho com o Hospital da região... Ai tem o berçário de risco... então tem aquela troca. A gente atende os bebês de risco, e isso chega nas pediatras. Então, tem esse lado. Mas eu acho que a prevenção, quando você vai fora... você pega muito mais... Porque se você vai na creche... Não é todo mundo que tem problema... Você vai com uma postura mais preventiva. Você pode detectar um caso ou outro... Mas me parece muito mais uma atenção primária ...

D- Então fora... uma atenção mais preventiva e dentro... mais curativa... 
$E-\dot{E} .$.

D- Você acha que isso é o que tem que ser feito, ou é o que deve ser feito?

E- Eu não sei, porque eu não tenho a amostra de todas as regiōes. Isso eu não sei. Não... acho que tem que ter um equilibrio. Acho que tem muito atendimento... e pouca prevenção dentro da UBS... Acho que falta o outro lado. Por exemplo... já participei de grupo de gestantes... isso seria mais prevenção... Ela ainda vai ter o bebê e você já orienta sobre a amamentação, a psicóloga... Esses grupos são muito ricos...A mãe já vai trazendo as suas ansiedades, os seus medos, quando vai nascer... A psicologia tá ali... Aí o nenê nasceu ... os primeiros cuidados, a gente já dá uma dica...

D- Então também vem bebê? Você disse que vinha mais escolares...

E- Mas também tem uma porcentagem dos bebês... Isso tem crescido, depois do trabalho com o hospital, com o berçário... tá mais claro, e a gente tá recebendo mais. Antes eu fazia uma triagem... vinha uma criança de dois anos e tal... agora não... Já vem quatro, cinco... Eu faço triagem separada prá criança até três, quatro anos, prá não misturar com os maiores, e poder formar um grupo mais homogêneo...

D- Pediatra...

E- Pensei porque ele que cuida das crianças. Pensei nele como a pessoa que canaliza assim... Isto tem sido bem rico... Acho positivo.

D. Canaliza o que?

E- A gente começou a mostrar prá eles que fono não só curava, fazia terapia... Então só recebiamos quando tinha distúrbio de fala... vai prá fono e tal. Agora, a criança tá demorando prá falar... a senhora vai passar na fono do posto... Um outro caráter... e isso tá acontecendo. Tem aumentado, e eu tô achando muito positivo.

D- Mas ainda prá encaminhar crianças com problemas?

E- É... Exato. Não fala muito... ele fala poucas palavras... Então, vamos passar com a fono e tal.

D- Há então um maior reconhecimento do pediatra do trabalho que a Fonoaudiologia pode desenvolver?

E- Acho que aos pouquinhos... A gente teve um pouco de dificuldades. A gente propôs um grupo de desenvolvimento... porque tinha o pediatra, a fono, a TO e tal. Ai a pediatra falava a parte dela, e quando a fono ia falar ela saía da sala, a To vai falar eu saia... Pouca troca... ela também não aprende, não descobre o que a Fonoaudiologia tem prá passar. Então, fica mais no distúrbio mesmo. Mas teve um avanço, no sentido da criança até tá bem, no seu periodo de desenvolvimento... uma mãe mais ansiosa e tal... e o pediatra encaminhou... Achei bem preventivo... algumas orientações, não é caso prá terapia... uma dica aqui e ali... A pediatra pegou no ponto certo, assim...

D- Estimulação...

E- A fono fala bastante disso. Promover a estimulação da criança... do bebê... lo que que é isso. Então, essa palavra me apareceu ai. É uma palavra meio mágica, né? Mas a gente trabalha muito com isso, quando vocé tá com o paciente, com a mãe... a gente sempre procura discutir a estimulação. Que estimulação, que que ela está recebendo, qual é o ambiente, qual é a relação que ela tem com as pessoas...

D- Isso na atenção primária? 
E- Em tudo. Mas na atenção primária é bem importante.

D- Por que?

E- É positivo, porque a gente vê as crianças que não têm a estimulação, ou um ambiente pouco favorável... ou isolamento... A falta disso vai causar um problema depois... provavelmente.

D- Então, isso é prevenção?

E- Acho que é(Ri)...acho que é...

D- E prevenção...

E- Então, mas a estimulação é... quando eu falo com o pai... O pai em casa vai estimular... É nesse sentido. Então, a estimulação, garante ai uma prevenção. Problemas. Aí vem a palavra prevenção... Com a estimulação, você previne problemas... como positivo também... Eu acho que é isso...

D- Mais alguma coisa?

E- Eu não sei... uma coisa que me preocupa atualmente... é essa coisa da atenção primária, secundária, terciária... Vamos prevenir na saúde pública... Vamos dar enfoque prá isso. Vamos dar terapia em posto de saúde. Vamos fazer a reabilitação...

D- Por que te preocupa?

E- Porque... acho que não está muito claro para as pessoas assim, qual que é o papel do posto de saúde... de uma UBS.

D- Que pessoas?

E- Pessoas... profissionais... Fono, fisio, TO, pode ser o médico... profissionais. Se dentro da UBS nós temos que fazer reabilitação... É uma questão que eu tenho minhas dúvidas... as pessoas parecem que têm posições diferentes. Isso não está claro. Então, por falta de outros recursos, de Centros de Referências, Instituiçōes especializadas nisso... A UBS faz reabilitação. Eu não sei... Tenho minhas dúvidas se é isso, se a gente tem que fazer...

D- Fala das tuas dúvidas...

E- Se tem que ter esses centros, prá não ter reabilitação em posto de saúde...

D- Qualquer reabilitação?

E-...... Acho que sim...

D- Vamos chamar de terapia fonoaudiológica...

E- Ah... os casos breves eu acho muito cabivel numa UBS. Porque pela demanda, o que a gente vê são muitos casos, variados, né?

D- Quando você fala em reabilitação, você tá falando em que?

E- PC, deficiência mental mais severa, não limitrofes... esse acho que tá mais próximo. Mas esses outros casos, mesmo o deficiente auditivo... 15 anos de terapia por exemplo... Então, esses, eu não sei... Eu acho que tem que ter os locais prá estar fazendo as terapias... Isso tem que ter... Acho que tem que ter mais recursos, porque a população precisa disso... Mas por exemplo, a UBS, eu sinto como um local de rotatividade. Então os casos alta breve, que você enxerga um final... prá você dar 
possibilidade das pessoas passarem ali e circularem, né? Receberem a orientação, a dica, prevenção... Pronto, já pulou, já vem outro ... dá umas dicas ali, aqui e tal... E tem os casos de atendimento, mas que tem alta prevista... Os casos mais graves, eu já tenho um pouco de dificuldade de entender onde a gente atende...

D- Por que a dúvida?

E- Por que a dúvida? Porque quando eu sai da faculdade, eu aprendi que não era prá atender reabilitação em posto de saúde. Com essa formação... $E$ aí... eu vejo postos de saúde hoje, atendendo casos de reabilitação. Ficou uma oposição. Então...

D- Ficou uma oposição?

E- Entre a formação e a experiência prática. E aí que tá a interrogação. Eu vejo pessoas que estão estudando...

D- Eu não quero te por na berlinda. Eu é que estou na dúvida sobre o que você acha. Você concorda ou discorda da sua formação?

E- Tá... Não, eu concordo com a minha formação. Eu acho que a UBS deveria ter essa atenção mais primária. A terapia entra na UBS, mas as terapias mais breves, grupos de estimulação, tempo definido... Uma coisa de reciclagem...

D- E o que mais na atenção primária?

E- $O$ resto tem que ter centro de referência, senão a gente segura muito a demanda.

D- Então, você não tem muita dúvida?

E- É... eu tenho dúvida com o que as pessoas estão fazendo, né? Pelo menos parece que eu tenho uma posição... o que eu acho...

D- Os outros fonoaudiólogos?

E- E... a coordenadora da saúde dos deficientes na minha regional, acha que a UBS tem que atender reabilitação, e ela fica pressionando as pessoas para atenderem. Vem de cima, alguém que obriga você a atender. Então, não tem uma discussão, se devia ser feito, se tem lugar, se é o lugar prá ser feito... Então, tem a equipe mínima que vai atender... Parece que é uma forma... bom não tem outro recurso, então nós temos que usar esses profissionais que tão em UBS. Tem fono, fisio e TO... Nós temos uma equipe minima de reabilitação, então vamos começar a formar uma referência. Então, faz esse sentido... Se vê que realmente é tão carente, que quando vai encaminhar... ali pode ser uma referência... E... mas eu não sei se é o certo. Na minha opinião, não deveria ser assim. Deveria se criar estratégias, porque nāo tem um lugar prá ser atendido... e ter ou no próprio hospital que tem a área de reabilitação... eu vejo assim.

D- E o que mais?

E- Acho que também a atuação mais em grupos dentro da UBS... Esses grupos que tem um caráter totalmente preventivo. Gestante, de puericultura, desenvolvimento, né? Então sim... eu acho que deveria ocorrer mais... com a maior frequência. Isso diminuiu até mesmo na área médica... eu sinto atualmente... quanto à desmotivação do salário, o profissional tá mais desmotivado, e em vez de investir e fazer um grupo... vai lá e atende os pacientes, aquela coisa mais rotineira... Vem aqui só prá isso e acabou. Então, em vez de pensar... e grupo exige uma dinâmica. Você não vai chegar lá e ficar ditando normas, ou fazer sempre igual... Um grupo você tem que estar aberto... É mais dificil trabalhar com grupo do que atender ali. Então, eu sinto isso. Tem profissionais que preferem deixar de lado e eu vou atender, só vou fazer isso e tal. E está se perdendo um pouco esses grupos que são valiosos. Eu acho que isso teria que ter mais. 
D. Então seria basicamente os grupos de caráter preventivo e os atendimentos breves.

E- Mesmo os adultos, que a fono acaba não entrando... Mas tem grupo de hipertensos. Ai tem outros grupos dentro da UBS, e esses grupos acontecem, mas são meio flutuantes. Às vezes tem mais, às vezes tem menos... Aquela coisa de ser contínua... Então o que acontece, eu acho que depende da motivação de cada profissional... E como passar isso pros pacientes, prá eles também se motivarem a participar ...

D- Os usuários são motivados, eles curtem esses grupos?

E- É... alguns sim... Eu participei de gestantes por exemplo, elas... elas tinham a vontade de continuar ... que era uma vez por semana. Aquele mês era um grupo, e cada vez era um aspecto que era abordado... elas iam até a última semana... apareciam... Foi um grupo que deu muito certo... Com as coisas que elas estavam aprendendo, compartilhando coisas... Acho que tem a ver que a equipe era gostosa, as pessoas tinham uma forma de mostrar a importáncia do grupo e aí o grupo foi prá frente. E um que não deu prá frente, eu acho que tem a ver com o profissional, pouco envolvido. Algumas das experiências que eu observei... ou outros casos, a pessoa procura o médico prá controlar a pressão. Quer o remédio em si. O médico fala que tem um grupo, prá te orientar em relação à alimentação, aos seus hábitos, à sua forma de viver, sei lá... Dá uma dica, mas por mais que o médico ache importante isso, às vezes o paciente em si tem as suas resistências pessoais. Acha que pegando o remédio vai resolver. A pressão vai ficar controlada, e vai prá casa. Então, eu já vi pessoas ótimas, que fizeram um trabalho super bom, e o grupo teve pouquissimas pessoas, e não conseguiu chegar. O que aconteceu? Não avalio que é só o profissional. É do povo também (ri)...

D- Mais alguma coisa?

E- Não... Acho que já falei tudo.

D- Obrigada. 
MAPA 2

Primeiro Mapa: ASSOCIAÇÕES E VALENCIAS PARA A PALAVRA FONOAUDIOLOGIA (Sujeito 1)

\begin{tabular}{|c|c|c|c|}
\hline Ocorrência & Positivo & Negativo & Neutro \\
\hline Comunicação & $\begin{array}{l}\text { A questão do tornar comum, } \\
\text { partilhar fala, contexto }\end{array}$ & & \\
\hline Linguagem & $\begin{array}{l}\text { Você poder ir construindo, a } \\
\text { lgg, uma fala, e poder estar } \\
\text { trocando ela com o outro. }\end{array}$ & & \\
\hline Fala & $\begin{array}{l}\text { A medida que ele vai } \\
\text { cresendo e vai podendo } \\
\text { adquirir e } \\
\text { aprender a fala. }\end{array}$ & $\begin{array}{l}\text { Entra a parte de Fono, } \\
\text { de distúrbio. }\end{array}$ & \\
\hline Voz & $\begin{array}{l}\text { Ter voz, está ligado à } \\
\text { questão da cidadania. }\end{array}$ & Não ter voz & \\
\hline Audição & & $\begin{array}{l}\text { Tem tanto distúrbio } \\
\text { de audição.. e as } \\
\text { crianças vão aparecer } \\
\text { com } 9 \text { ou } 10 \text { anos e } \\
\text { nunca fizeram nada. }\end{array}$ & \\
\hline Interação & $\begin{array}{l}\text { Uma ação onde dá prá ter no } \\
\text { minimo } 2 \text { pessoas. Você se } \\
\text { propôe a estar trocando. }\end{array}$ & & \\
\hline Interlocução & Já é uma fala, uma lgg com 2. & & \\
\hline Distúrbio & $\begin{array}{l}\text { Porque é o objeto do meu } \\
\text { trabalho. }\end{array}$ & $\begin{array}{l}\text { A gente não ter } \\
\text { profissional } \\
\text { suficiente. }\end{array}$ & \\
\hline Relação & $\begin{array}{l}\text { Pressupõe algum nível de } \\
\text { comunicação, troca, estar } \\
\text { aberto }\end{array}$ & & \\
\hline Essência & $\begin{array}{l}\text { A voz da pessoa é a } \\
\text { essência. A expressão da } \\
\text { gente como essência. }\end{array}$ & & \\
\hline Ação & $\begin{array}{l}\text { Pelo movimento que a Fono } \\
\text { tem trazido prá minha vida. }\end{array}$ & & \\
\hline Dois & $\begin{array}{l}\text { Prá interação, precisa de } \\
\text { dois. }\end{array}$ & & \\
\hline Sujeitos & $\begin{array}{l}\text { Que a gente possa fazer esse } \\
\text { resgate com as pessoas. }\end{array}$ & & \\
\hline Cidadania & $\begin{array}{l}\text { Eu acho que a Fono também } \\
\text { está ligada ao resgate da } \\
\text { cidadania. Ter voz.. Fazer } \\
\text { história. }\end{array}$ & & \\
\hline
\end{tabular}


MAPA 3

Primeiro Mapa: ASSOCIAÇõES E VALENCIAS PARA A PALAVRA

SAUDE (Sujeito 1)

\begin{tabular}{|c|c|c|c|}
\hline Ocorrência & Positivo & Negativo & Neutro \\
\hline Promoção & $\begin{array}{l}\text { O início da saúde. A } \\
\text { coisa maior. O cuidado. }\end{array}$ & & \\
\hline ||Doença & & \begin{tabular}{|l|} 
O contrário. \\
Resgatar aquilo que \\
está doente.
\end{tabular} & \\
\hline \begin{tabular}{|l} 
Situação \\
política, \\
social e \\
cultural
\end{tabular} & & $\begin{array}{l}\text { A gente está vivendo } \\
\text { uma situação super- } \\
\text { séria. }\end{array}$ & \\
\hline Resgate & Resgatar a saúde. & & \\
\hline Familia & $\begin{array}{l}\text { Como um ambiente onde } \\
\text { as pessoas possam ter. }\end{array}$ & & \\
\hline Contexto & $\begin{array}{l}\text { Que contexto de saúde a } \\
\text { gente tem. A coisa maior } \\
\text { do Brasil mesmo. }\end{array}$ & & \\
\hline Ambiente & \begin{tabular}{|l|} 
A gente tenta tornar o \\
ambiente o mais positivo \\
possivel e continuar com \\
saúde, poder cuidar dela.
\end{tabular} & & \\
\hline
\end{tabular}


MAPA 4

Primeiro Mapa: ASSOCIAÇÕES E VALÊNCIAS PARA A PALAVRA

FONO NA AT. PRIMÁRIA (Sujeito 1)

\begin{tabular}{|c|c|c|c|}
\hline Ocorrência & Positivo & Negativo & Neutro \\
\hline Conhecimentos & \begin{tabular}{|l|} 
Coisas a oferecer \\
as pessoas
\end{tabular} & & \\
\hline Base & $\begin{array}{l}\text { E o início de um } \\
\text { processo. } \\
\text { Começa ai. }\end{array}$ & & \\
\hline Relaçōes & \begin{tabular}{|l} 
Que vai se \\
estabelecer com a \\
comunidade.
\end{tabular} & & \\
\hline Cuidados & $\begin{array}{|lr|}\text { A gente pode } & \text { ter } \\
\text { em relação } & \text { à } \\
\text { criança. } & \\
\end{array}$ & $\begin{array}{l}\text { Remédios } \\
\text { caseiros. }\end{array}$ & \\
\hline Troca & $\begin{array}{|lr|}\text { O que a gente tem } \\
\text { prá } & \text { oferecer... } \\
\text { Que eles } & \text { estão } \\
\text { pedindo } & \text { prá } \\
\text { gente... } & \end{array}$ & & \\
\hline $\begin{array}{l}\text { Outros niveis de } \\
\text { atenção }\end{array}$ & \begin{tabular}{|l|} 
Estabelecer uma \\
rede. Se tivesse
\end{tabular} & Não têm. & \\
\hline
\end{tabular}




\section{ANEXO 5}

MAPA 5

Segundo Mapa:SíNTESE DE ASSOCIAÇÕES PARA FONOAUDIOLOGIA POR CATEGORIA PARA CADA ENTREVISTA SEPARADAMENTE

\begin{tabular}{|c|c|c|c|c|}
\hline $\boldsymbol{N}^{\mathbf{0}}$ & CATEGORIA & CCATEGORIA & CATEGORIA & CATEGORIA \\
\hline ENTREVISTA & ESSENCIA & H. & MEDIADOR & QUALIFICADOR \\
\hline 1 & $\begin{array}{l}\text { Comunicação, } \\
\text { Essência } \\
\text { Cidadania } \\
\end{array}$ & $\begin{array}{l}\text { Linguagem, Fala, Voz, Audição, } \\
\text { Distúrbio,Sujeitos }\end{array}$ & $\begin{array}{l}\text { Interaçāo, Interlocução, } \\
\text { Relaçāo, Dois }\end{array}$ & Açäo \\
\hline 2 & $x 00 x$ & Audição, Linguagem & Terapia, Terapêuta & Valorizaçāo \\
\hline 3 & $\infty 00 \alpha$ & $\begin{array}{l}\text { Faixa etária grande, Preventivo, } \\
\text { Terciário }\end{array}$ & $x \infty x$ & $x 00 x$ \\
\hline 4 & Ciência & Audição e Fala & $x 00 x$ & 2000 \\
\hline 5 & Profissão & Criança & $x 00 x$ & Dificuldade, Sucesso \\
\hline 6 & $x 00 x$ & $\begin{array}{l}\text { Reabilitaçāo,Clínica, Motricidade } \\
\text { Oral, Prevençāo, Atençāo, }\end{array}$ & Atendimento & $\begin{array}{l}\text { Categoria Nova, } \\
\text { Mobilização } \\
\text { Ampliação } \\
\end{array}$ \\
\hline 7 & $x 000 x$ & $\begin{array}{l}\text { Estudo da Audiçāo e da } \\
\text { Fonoarticulação, } \\
\text { Criança,Crescimento }\end{array}$ & $x x x x$ & $\begin{array}{l}\text { Empolgação } \\
\text { Mal-Remunerado }\end{array}$ \\
\hline 8 & $x \infty \alpha$ & Linguagem, Saúde & $\begin{array}{l}\text { Familia, Relaçöes, } \\
\text { Contato,Trocar, } \\
\text { Compartilhar,Falar, Ouvir }\end{array}$ & $\infty 00 x$ \\
\hline 9 & Comunicaçāo & Aprender a falar e a ouvir & $\begin{array}{l}\text { Auxilio, Apoio, Ajuda, } \\
\text { Orientação }\end{array}$ & $x 00 x$ \\
\hline 10 & $x 00 x$ & 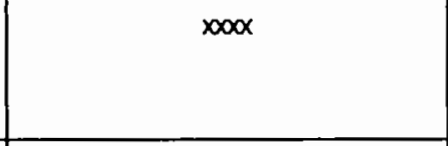 & $200 x$ & $\begin{array}{l}\text { Salário baixo } \\
\text { Falta diretriz de estudo } \\
\text { Insatisfação, País dificil p/ } \\
\text { a Fonoaudiologia }\end{array}$ \\
\hline 11 & Comunicaçāo & $\begin{array}{l}\text { Prevenção,Linguagem } \\
\text { Pacientes, Queixa, }\end{array}$ & $\begin{array}{l}\text { Terapia, Diagnóstico } \\
\text { Encaminhamentos }\end{array}$ & $\begin{array}{l}\text { Problema.Salário, } \\
\text { Dificuldade } \\
\text { Reconhecimento } \\
\text { Estudo constante } \\
\end{array}$ \\
\hline 12 & 2000 & Fala & $\begin{array}{l}\text { Odontologia, Dicionário, } \\
\text { Ginástica, Festa }\end{array}$ & $\begin{array}{l}\text { Lógica, Nacional, Útil } \\
\text { Expandir, Inteligência } \\
\text { Amadora, Animadora }\end{array}$ \\
\hline 13 & Profissão & $x 000$ & $\begin{array}{l}\text { Envolvimento, Emocional } \\
\text { Nivel de Commp. Mental }\end{array}$ & $\begin{array}{l}\text { Necessário } \\
\text { Não valorizado, Cobrado } \\
\end{array}$ \\
\hline 14 & $200 \alpha$ & Fala, Audiçāo, Criança, Distúrbio & Terapia & Paciència, Persistência \\
\hline 15 & $x \times 0 x$ & $\begin{array}{l}\text { Linguagem, Criança } \\
\text { Falar, Ouvir, Audiçāo, } \\
\text { Voz, Habilidades } \\
\text { Potencialidades } \\
\text { Leitura e Escrita } \\
\text { Problema, Prevençāo } \\
\text { Bebê, Desenvolvimento }\end{array}$ & $\begin{array}{l}\text { Pais, Brincar } \\
\text { Troca de Experiências } \\
\text { Interação, Materiais } \\
\text { Conscientização, Dentistas } \\
\text { Médicos, Professores } \\
\text { Escolas, Creches } \\
\text { Equipe Multidisciplinar }\end{array}$ & $x 00 x$ \\
\hline 16 & Trabalho & $\begin{array}{l}\text { Fala, Linguagem, Audição,Criança, } \\
\text { Prevenção }\end{array}$ & Terapia & $x 000$ \\
\hline 17 & $\begin{array}{l}\text { Trabalho, } \\
\text { Comunicação }\end{array}$ & $\begin{array}{l}\text { Linguagem, Prevençāo, Voz, Fala, } \\
\text { Leitura e Escrita, Crianças, Saúde }\end{array}$ & $\begin{array}{l}\text { Social, Interaçāo, Oficinas, } \\
\text { Pais, Equipe Interdisciplinar }\end{array}$ & $x 000$ \\
\hline 18 & Comunicação & $x 00 x$ & Interação, Entrosamento & Iniciativa, Criatividade \\
\hline 19 & $\begin{array}{l}\text { Comunicação } \\
\text { Trabalho } \\
\end{array}$ & Linguagem, Aprimoramento & $\begin{array}{l}\text { Relação, Contato, Ouvir, } \\
\text { Falar, Conversar, Brincar }\end{array}$ & 2000 \\
\hline 20 & $000 x$ & $x 000$ & $x 00 x$ & $\begin{array}{l}\text { Atraente,Bonita,Refinado, } \\
\text { Essencial,Triste }\end{array}$ \\
\hline
\end{tabular}




\section{MAPA 6}

Segundo Mapa:SínTESE DE ASSOCIAÇÕES PARA SAÚDE POR CATEGORIA PARA CADA ENTREVISTA SEPARADAMENTE

\begin{tabular}{|c|c|c|c|c|}
\hline & ESSENCIA & क्, OBJETO & MEDIADOR & QUALIFICADOR \\
\hline 1 & $x x x$ & Promoção, Doença & $\begin{array}{l}\text { Sit. Polit., Soc., Cult. } \\
\text { Contexto, Ambiente } \\
\text { Famillia }\end{array}$ & $x x x x$ \\
\hline 2 & $\begin{array}{l}\text { Bem-Estar Bio-Psico- } \\
\text { Social }\end{array}$ & $\begin{array}{l}\text { Sujeito Integral } \\
\text { Orgânico, Doença }\end{array}$ & Social & Respaldo \\
\hline 3 & $x x x x$ & Doença & $\begin{array}{l}\text { SUS } \times \text { PAS } \\
\text { Subsídios }\end{array}$ & $\begin{array}{l}\text { Dificuldade na relaçâo com } \\
\text { os pacientes }\end{array}$ \\
\hline 4 & Bem-Estar & $\begin{array}{l}\text { Condiçöes legais de vida } \\
\text { Doença }\end{array}$ & $x x x x$ & $x x x x$ \\
\hline 5 & $x x x x$ & Prevenção & Remédio & Dificuldade \\
\hline 6 & Bem-Estar & Promoção de Saúde & Atenção & $\begin{array}{l}\text { Básica } \\
\text { Carência } \\
\text { Irresponsabilidade }\end{array}$ \\
\hline 7 & $\begin{array}{l}\text { Bem-Estar psiquico, } \\
\text { físico }\end{array}$ & $x x x x$ & $x \infty x$ & Saudável \\
\hline 8 & $\begin{array}{l}\text { Bem-Estar } \\
\text { Alegria } \\
\text { Aberta } \\
\end{array}$ & $x x x$ & $x x x x$ & $x 00 x$ \\
\hline 9 & $x x x x$ & $x x x x$ & $x x x x$ & Tristeza, Crise \\
\hline 10 & Mental, Direito & $x x x$ & $x \times x x$ & $x x x$ \\
\hline 11 & $x \infty x$ & $\begin{array}{l}\text { Individual } \\
\text { Prevenção }\end{array}$ & $\begin{array}{l}\text { Social } \\
\text { Clinica }\end{array}$ & $\begin{array}{l}\text { Dificuldade } \\
\text { Quantidade } \\
\text { Qualidade } \\
\end{array}$ \\
\hline 12 & Amor & $x \infty x$ & $\begin{array}{l}\text { Sexo, Droga } \\
\text { Estudo } \\
\end{array}$ & Ütil \\
\hline 13 & Direito & $x x \infty x$ & Educação & $\begin{array}{l}\text { Muito rara } \\
\text { não valorizada }\end{array}$ \\
\hline 14 & Prioridade & Prevenção & Tratamento & $x x x$ \\
\hline 15 & $x x x$ & $\begin{array}{l}\text { Pessoas,Prevenção, } \\
\text { Doença }\end{array}$ & $\begin{array}{l}\text { Prefeitura, Hospital } \\
\text { Terapias, Alimentação, } \\
\text { Higiene, Habitação, } \\
\text { Saneamento, Educação, } \\
\text { Médico } \\
\end{array}$ & $x \times x$ \\
\hline 16 & Bem-Estar, Vida & Doença & Cuidados, Serviços & Possibilidade \\
\hline 17 & Social & $\begin{array}{l}\text { Individuo, Grupo, } \\
\text { Coletivo } \\
\text { Integração, Prevenção }\end{array}$ & $x x x x$ & Total \\
\hline 18 & $x x x x$ & $x \infty x$ & $\begin{array}{l}\text { Ações Educativas } \\
\text { Paticipação da } \\
\text { População }\end{array}$ & $x 0 x x$ \\
\hline 19 & Bem-Estar, Vida & $x x \infty x$ & Médico, Paciente & $\begin{array}{l}\text { Gostoso } \\
\text { Precariedade }\end{array}$ \\
\hline 20 & $x x x x$ & $x x x$ & $\begin{array}{l}\text { Estudo, Higiene, } \\
\text { Alimentação, Carinho, } \\
\text { Lazer, Viajar }\end{array}$ & Beleza \\
\hline
\end{tabular}


MAPA 7

Segundo Mapa:SÍNTESE DE ASSOCIAÇÕES PARA FONOAUDIOLOGIA NA ATENÇÃO PRIMÁRIA

POR CATEGORIA PARA CADA ENTREVISTA SEPARADAMENTE

\begin{tabular}{|c|c|c|c|c|}
\hline & WESSENCIA & , OBJETO & MEDIADOR & QUALIFICADOR \\
\hline 1 & $\mathbf{x} \times \mathbf{x}$ & $x \infty \infty x$ & $\begin{array}{l}\text { Conhecimentos, Relações, } \\
\text { Cuidados, } \\
\text { Troca, Outros niveis de Atenção }\end{array}$ & Base \\
\hline 2 & $\begin{array}{l}\text { Porta de Entrada } \\
\text { Resolução de maior } \\
\text { parte dos problemas }\end{array}$ & $x \infty x$ & UBS & Difícil \\
\hline 3 & $x<0 x$ & $x \times x x$ & $\begin{array}{l}\text { Programas Educativos } \\
\text { Triagem Auditiva } \\
\text { Creches, Escolas }\end{array}$ & $x 00 \alpha$ \\
\hline 4 & $x \times \infty x$ & $\begin{array}{l}\text { Prevençāo, Saúde, } \\
\text { Doença }\end{array}$ & Atendimento & Angústia \\
\hline 5 & $\infty \infty \infty x$ & Prevenção & Terapia, Orientação & $x \times 0 x$ \\
\hline 6 & $x \times 0 \times x$ & $x \times x$ & $\begin{array}{l}\text { Informação } \\
\text { Trabalho Interdisciplinar }\end{array}$ & Expansão \\
\hline 7 & $x \times 00 x$ & Preventivo & $\begin{array}{l}\text { Mães, Professoras, } \\
\text { ADls, Trabalho Multiprofissional } \\
\text { Sensibilizar outros profissionais } \\
\text { Laudo de outros profissionais }\end{array}$ & $x \times x$ \\
\hline 8 & $x 000$ & Saüde, Prevenção & $x \times x x$ & Dificuldades \\
\hline 9 & $x \times x x$ & Bebezinhos & Orientação & Ideal \\
\hline 10 & $x 00 x$ & Prevenir & $x \times x \times$ & Ter mente aberta \\
\hline 11 & $x \times x x$ & $\begin{array}{l}\text { Trabalho com a } \\
\text { comunidade, } \\
\text { preventivo, } \\
\text { Saúde Escolar } \\
\text { Comunidade } \\
\end{array}$ & $\begin{array}{l}\text { UBS, Lista de Espera } \\
\text { Pediatria } \\
\text { Discutir com a população }\end{array}$ & $\begin{array}{l}\text { Frustração, Confuso, } \\
\text { Leque grande de opçōes } \\
\text { Perdida, Quantidade de } \\
\text { Atendimento, Vergonhoso, } \\
\text { Desestimulante }\end{array}$ \\
\hline 12 & $x \times x x$ & Prevenção, Estudo & Socorro, Ajuda, Orientaçāo & $x x \times x$ \\
\hline 13 & $x<\infty$ & $\begin{array}{l}\text { Prevenção } \\
\text { Prevenção Escolar }\end{array}$ & Atendimento Global & $x \times \infty x$ \\
\hline 14 & $x 00 x$ & $x \times x x$ & $\begin{array}{l}\text { Grupos de Orientação, Escolas, } \\
\text { Atendimento }\end{array}$ & $x \times x x$ \\
\hline 15 & $x \times x x$ & $\begin{array}{l}\text { Criança, Estimulação, } \\
\text { Prevenção }\end{array}$ & $\begin{array}{l}\text { Orientação, Conheci/o, Creche, Be } \\
\text { rçário, Pediatria }\end{array}$ & $x x x x$ \\
\hline 16 & $x 00 \alpha$ & $\begin{array}{l}\text { Prevenção } \\
\text { Promoção de Saúde }\end{array}$ & Atendimento UBS & $x \times x x$ \\
\hline 17 & Saúde Total Integral & Prevenção & $x \times x x$ & $\infty 0 x$ \\
\hline 18 & $x \times x \times$ & $x \operatorname{cox} x$ & $\begin{array}{l}\text { Entrosalo c/ outros profissionais } \\
\text { Grupos de Puericultura } \\
\text { Pré-Escola c/ Professor }\end{array}$ & Disponibilidade \\
\hline 19 & Porta de Entrada & Prevenção & $x \alpha 0 x$ & $\begin{array}{l}\text { Básico,Fundamental } \\
\text { Amplo, Muito Legal }\end{array}$ \\
\hline 20 & $x<x x$ & $\begin{array}{l}\text { Preventivo } \\
\text { Clínico/Terapêutico } \\
\text { Demanda }\end{array}$ & $\begin{array}{l}\text { Trabalhar a população da } \\
\text { unidade e dos usuários } \\
\text { Creches e Escolas, Puericultura }\end{array}$ & $\begin{array}{l}\text { Muita Responsabilidade } \\
\text { Pioneiro, Muito Estudo } \\
\text { Sociabilidade/Simpatia } \\
\text { Paciência }\end{array}$ \\
\hline
\end{tabular}

